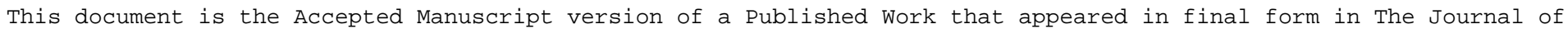

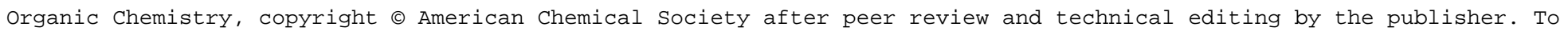

access the final edited and published work see http://pubs.acs.org/doi/abs/10.1021/jo400254q

\title{
Pd(0)-Catalyzed Alkene Oxy- and Aminoalkynylation with Aliphatic Bromoacetylenes
}

Stefano Nicolai, Raha Sedigh-Zadeh, Jérôme Waser*

Laboratory of Catalysis and Organic Synthesis, Ecole Polytechnique Fédérale de Lausanne, EPFL SB

ISIC LCSO, BCH 4306, 1015 Lausanne, Switzerland

jerome.waser@epfl.ch

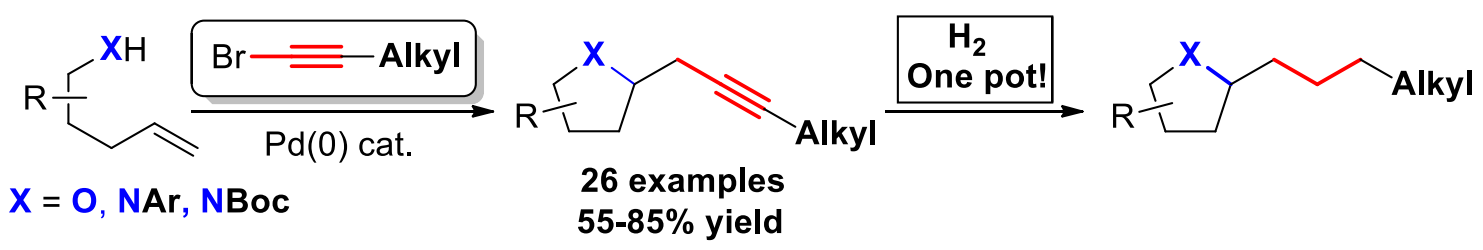

ABSTRACT: Tetrahydrofurans and pyrrolidines are among the most important heterocycles found in bioactive compounds. Cyclization-functionalization domino reactions of alcohols or amines onto olefins constitute one of the most efficient methods to access them. In this context, oxy- and aminoalkynylation are especially important reactions, due to the numerous transformations possible with the triple bond of acetylenes, yet these methods have been limited to the use of silyl protected acetylenes. Herein, we report the first palladium-catalyzed oxy- and aminoalkynylation using aliphatic bromoalkynes, which proceeded with high diastereoselectivity and functional group tolerance. A one-pot hydrogenation of the triple bond gave then access to alkyl-substituted tetrahydrofurans and pyrroldines. Finally, a detailed study of the side products formed during the reaction gave a first insight into the reaction mechanism.

\section{Introduction}

Saturated heterocycles are essential substructures in a large variety of natural and synthetic bioactive compounds. Tetrahydrofurans and pyrrolidines substituted with functionalized aliphatic chains on positions $\mathrm{C}_{2}$ and/or $\mathrm{C}_{5}$ are of particular interest due to their presence in natural products exhibiting significant biological and pharmacological activity. Eminent examples include trans-2,5-disubstituted tetrahy- 
drofurans in antitumoral annonaceous acetogenins, such as gigantecin $(\mathbf{1})^{1}$ or $c i s-2,5$-disubstituted pyrrolidines in antiviral broussonetines, such as broussonetine $\mathrm{G}(\mathbf{2})^{2}$ or in the antifungal preussin (3) (Figure 1$)^{3}$
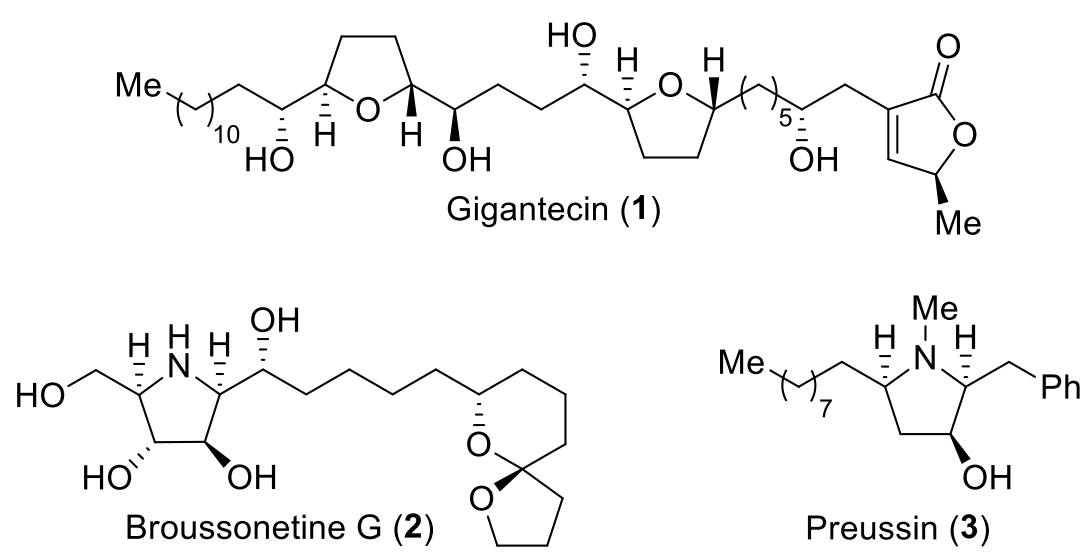

Figure 1. Examples of biologically active natural products containing 2,5-disubstituted tetrahydrofurans and pyrrolidines.

One important approach for the synthesis of functionalized tetrahydrofurans and pyrrolidines relies on the Pd-catalyzed cyclization of an oxygen or nitrogen nucleophile onto a tethered alkene followed by further C-O, C-C or C-N bond formation. ${ }^{4-6}$ When considering the large variety of available subsequent transformations for the $\mathrm{C} \equiv \mathrm{C}$ triple bond, the formation of $\mathrm{a} \mathrm{sp}^{3}$-sp bond in this process would be highly desirable. This transformation requires the use of an electrophilic acetylene source. Recent years produced impressive progress in the field of electrophilic alkynylation of aromatic and aliphatic C-H bonds using Pd catalysis. ${ }^{7}$ In these processes, acetylenes bearing bulky silyl groups have been used most often, followed by aryl acetylenes. On the other hand, the use of aliphatic acetylenes has been much more limited. Several reasons concur to make this class of substrates more challenging: The different electronic properties change the kinetic of key catalytic steps, especially reductive elimination; the triple bond is more accessible for direct reaction with the metal catalyst; finally the presence of hydrogen or functional groups at the propargylic position open the way for isomerization side reactions.

In 2011, we reported the first example of intramolecular Pd(0)-catalyzed oxy- and amino-alkynylation of $\gamma$-hydroxy alkenes using electrophilic bromoacetylenes (Scheme 1). ${ }^{8}$ These transformations were 
complementary to the oxy- and aminoalkynylation methods we previously developed for the synthesis of propargyl lactones and lactams under $\mathrm{Pd}(\mathrm{II}) / \mathrm{Pd}(\mathrm{IV})$-catalysis using the hypervalent iodine reagent TIPS-EBX. ${ }^{9}$ Nevertheless, both methods were limited to the use of silylated alkynyl bromides as electrophiles. This limitation makes the method less attractive for the convergent synthesis of alkylsubstituted tetrahydrofurans and pyrrolidines after reduction of the triple bond. In principle, similar products could be accessed also via an olefin heterovinylation or heteroalkylation approach. However, the former has been realized only with unfunctionalized aliphatic substituents on the alkene so far ${ }^{6 i, k, 1}$ and the latter is an unknown process.

Herein, we would like to report the first successful Pd-catalyzed oxy- and aminoalkynylation of aliphatic bromo acetylenes (Scheme 1). The method was successfully applied to both alcohols and $N$-Boc protected amines with high diastereoselectivity. For the first time, we were able to use bromoacetylenes bearing functionalized aliphatic chains. The obtained alkynes can be easily reduced to the alkyl chains in a practical one-pot process. Finally, a detailed study of the side products formed during oxyalkynylation allowed us to gain a first insight into the reaction mechanism.

Scheme 1. Extending the scope of heteroalkynylation to aliphatic alkynes.

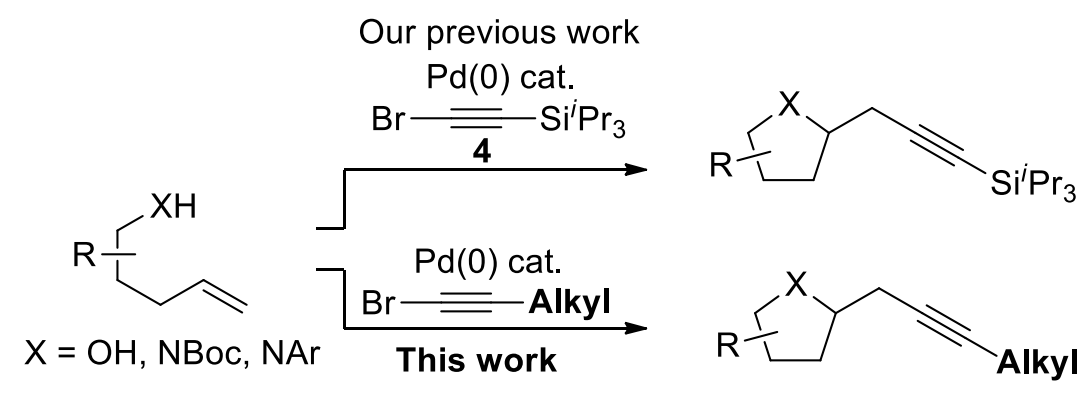

\section{Results and Discussion}

Commercially available 4-penten-1-ol (5a) was initially selected as the model substrate to investigate the oxyalkynylation with aliphatic bromo acetylenes. A complex mixture had been observed when phenylethyl ethynyl bromide had been used as the alkynylating reagent. ${ }^{8}$ In order to eliminate any potential negative influence of the phenyl group in close proximity to the triple bond, 1-bromooctyne (6a) was 
examined in the reaction. Indeed, the desired 2-nonynyl tetrahydrofuran 7aa could be obtained in $44 \%$ yield using $\mathrm{Pd}_{2}(\mathrm{dba})_{3}$ as palladium source and bis(2-diphenylphosphinophenyl)ether (DPEPHos) as ligand (Table 1, entry 1). Starting from this lead result, the influence of the palladium source was further evaluated. The use of $\mathrm{PdCl}_{2}\left(\mathrm{PPh}_{3}\right)_{2}$ (entry 2) or $\mathrm{Pd}(\mathrm{OAc})_{2}$ (entry 3) as precatalysts led to lower yields. A significant improvement was observed with $N$-heterocyclic carbene Pd-complex 8 , which gave the product in 56\% yield in the presence of DPEPHos (entry 4). However, no conversion could be observed when the same Pd complex was used in the absence of DPEPHos (entry 5), suggesting that the carbene ligand had no influence on the reaction. Similar yields were obtained when the reaction was performed with complexes bearing only weakly coordinated ligands, such as $[\mathrm{Pd}($ allyl $)(\mathrm{cod})]\left(\mathrm{BF}_{4}\right)_{2}$ (entry 6). $[\mathrm{Pd}($ cinnamyl $) \mathrm{Cp})]$, a reported clean source of $\mathrm{Pd}^{0}$ for catalysis,${ }^{10}$ led to the same result obtained with $[\mathrm{Pd}($ allyl $)(\mathrm{cod})]\left(\mathrm{BF}_{4}\right)_{2}$ (entry 7$)$. The use of $\mathrm{Pd}(\mathrm{dba})_{2}$ also resulted in a slight improvement of the yield when compared to $\mathrm{Pd}_{2}(\mathrm{dba})_{3}$ (entry 8 ). This result raises the question wether enone ligands have a favorable effect on the reaction. However, when dba was added to $[\mathrm{Pd}($ allyl $)(\mathrm{cod})]\left(\mathrm{BF}_{4}\right)_{2}$, no increase in yield was observed (entry 9). The use of other enone ligands led to a decrease in yield. ${ }^{11}$ Overall, this series of experiments demonstrated that the source of Pd had only a limited influence on the reaction outcome. At this point, $\mathrm{Pd}(\mathrm{dba})_{2}$ was identified as the best compromise between price and efficiency for the screening of reaction conditions.

Table 1: Screening of Pd catalysts and alkynyl reagents.

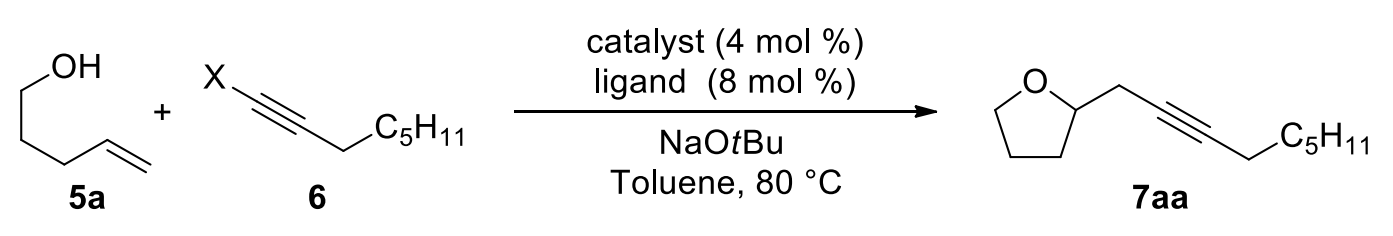

\begin{tabular}{ccccc} 
Entry & $\mathrm{X}$ & Catalyst & Ligand & Yield $^{\mathrm{a}}$ \\
\hline 1 & $\mathrm{Br}(\mathbf{6 a})$ & $\mathrm{Pd}_{2}(\mathrm{dba})_{3}$ & DPEPHos & $44 \%$ \\
2 & $\mathrm{Br}(\mathbf{6 a})$ & $\mathrm{PdCl}_{2}\left(\mathrm{PPh}_{3}\right)_{2}$ & DPEPHos & $31 \%$
\end{tabular}




\begin{tabular}{|c|c|c|c|}
\hline 3 & $\operatorname{Br}(\mathbf{6 a})$ & $\mathrm{Pd}(\mathrm{OAc})_{2}$ & DPEPHos \\
\hline 4 & $\operatorname{Br}(\mathbf{6 a})$ & NHC-Pd $(\mathbf{8})^{\mathrm{b}}$ & DPEPHos \\
\hline 5 & $\operatorname{Br}(\mathbf{6 a})$ & NHC-Pd (8) $)^{\mathrm{b}}$ & - \\
\hline 6 & $\operatorname{Br}(\mathbf{6 a})$ & {$[\mathrm{Pd}($ allyl $)(\mathrm{cod})] \mathrm{BF}_{4}$} & DPEPHos \\
\hline 7 & $\operatorname{Br}(\mathbf{6 a})$ & {$[\mathrm{Pd}($ cinnamyl $) \mathrm{Cp}]$} & DPEPHos \\
\hline 8 & $\operatorname{Br}(\mathbf{6 a})$ & $\operatorname{Pd}(\mathrm{dba})_{2}$ & DPEPhos \\
\hline 9 & $\operatorname{Br}(\mathbf{6 a})$ & {$[\mathrm{Pd}($ allyl $)(\mathrm{cod})] \mathrm{BF}_{4} / \mathrm{dba}$} & DPEPHos \\
\hline 10 & $\operatorname{Br}(\mathbf{6 a})$ & $\mathrm{Pd}(\mathrm{dba})_{2}$ & DPEPHos \\
\hline 11 & $\operatorname{Br}(\mathbf{6 a})$ & $\operatorname{Pd}(d b a)_{2}$ & XantPhos \\
\hline 12 & $\operatorname{Br}(\mathbf{6 a})$ & $\operatorname{Pd}(\mathrm{dba})_{2}$ & dppf \\
\hline 13 & $\operatorname{Br}(\mathbf{6 a})$ & $\operatorname{Pd}(d b a)_{2}$ & SegPhos \\
\hline 14 & $\operatorname{Br}(\mathbf{6 a})$ & $\mathrm{Pd}(\mathrm{dba})_{2}$ & BINAP \\
\hline 15 & $\mathrm{Cl}(\mathbf{6} \mathbf{b})$ & $\operatorname{Pd}(d b a)_{2}$ & DPEPHos \\
\hline 16 & $\mathrm{I}(\mathbf{6 c})$ & $\operatorname{Pd}(\mathrm{dba})_{2}$ & DPEPHos \\
\hline
\end{tabular}

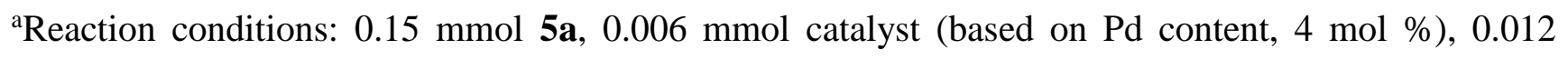
mmol DPEPHos (8 mol \%), 0.225 mmol 1-halooct-1-yne 6 (1.5 equiv), $0.225 \mathrm{mmol} \mathrm{NaOtBu}(1.5$ equiv), $0.8 \mathrm{~mL}$ toluene, $3 \mathrm{~h}, 80{ }^{\circ} \mathrm{C}$, yield was determined by GC-MS; ${ }^{\mathrm{b}}(\mathrm{NHC}) \mathrm{Pd}($ allyl $) \mathrm{Cl}(\mathbf{8})=\mathrm{Al}-$ lyl[1,3-bis(mesityl)imidazol-2-ylidene]palladium chloride; ${ }^{\mathrm{c}} 0.0060 \mathrm{mmol}$ DPEPHos (4 mol \%).

We decided to focus our attention next on the screening of different diphosphines as ligands. DPEPHos was optimal for the cyclization reaction with octynyl bromide 6a. An excess of this ligand was important to prevent a drop of the yield (entry 10). Other ligands were much less efficient than DPEPHos. Low yields were obtained with XantPhos and dppf (entries 11 and 12). While the former has similar electronic properties as DPEPHos, the latter displays a similar bite angle, but lacks the oxygen atom, 
which is a potential further weak coordination site. The bite angle of the chelating ligand is known to be a crucial parameter to favor reductive elimination over $\beta$-hydride elimination. ${ }^{12}$ In fact, no product was obtained with ligands having a smaller bite angle, such as SegPhos or BINAP (entries 13 and 14). The efficiency of different alkynyl halides was investigated next. Both octynyl chloride (6b) and iodide (6c) exhibited low reactivity and gave the desired product in low yields only (entries 15 and 16).

The choice of the base also had a strong influence on the outcome of the reaction. The use of $\mathrm{NaO} t \mathrm{Bu}$ was essential for success. Both $\mathrm{KO} t \mathrm{Bu}$ and $\mathrm{LiO} t \mathrm{Bu}$ gave the cyclized product only in traces. A modest yield (24\%) was obtained with NaHMDS, which further supported the importance of sodium as countercation. Moreover, a base strong enough to significantly deprotonate the alcohol was required, and no reactivity was observed with weaker bases such as sodium carbonate or sodium acetate. While no significant effect was observed in the presence of different additives, ${ }^{13}$ the reaction temperature was found to be important: running the reaction at lower temperature $\left(50^{\circ} \mathrm{C}\right)$ led to a significantly slower transformation, with low conversion of octynyl bromide (6a). By contrast, the reaction reached $45 \%$ yield after just one hour at higher temperature $\left(110^{\circ} \mathrm{C}\right)$, but without further improvement after a longer reaction time.

We concluded our studies on the optimization of the reaction with solvents and concentration effects (Table 2). The use of non-aromatic solvents resulted in very low yield (entries 1-5). Moderate yields were obtained with solvents similar to toluene, such as trifluorotoluene (entry 6) or xylene (entry 7). Finally, the reaction concentration had a strong effect on the reaction outcome. The yield dropped to $35 \%$ or less when the reaction was performed at higher concentration (entry 8) than the usual reaction (entry 9). On the contrary, a significant improvement up to $65 \%$ was observed under more diluted conditions (0.075 M) (entry 10). Further dilution did not lead to higher yields (entry 11). Under the optimized conditions, tetrahydrofuran 7 aa could finally be isolated in $69 \%$ yield on preparative scale (entry 12$).{ }^{14}$

\section{Table 2: Influence of solvents and concentration.}




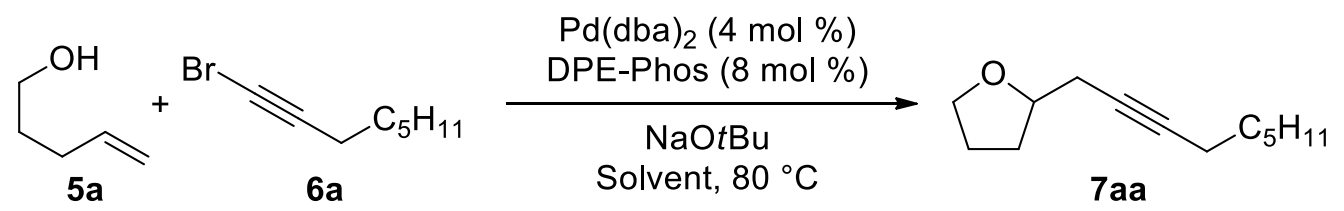

\begin{tabular}{cccc} 
Entry & Solvent & Concentration & Yield $^{\mathrm{a}}$ \\
\hline 1 & THF & $0.19 \mathrm{M}$ & $8 \%$ \\
2 & Dioxane & $0.19 \mathrm{M}$ & $\mathrm{nr}$ \\
3 & $\mathrm{CH}_{3} \mathrm{CN}$ & $0.19 \mathrm{M}$ & $\mathrm{nr}$ \\
4 & DMSO & $0.19 \mathrm{M}$ & $\mathrm{nr}$ \\
5 & $0.19 \mathrm{M}$ & $\mathrm{nr}$ \\
6 & DCE & $0.19 \mathrm{M}$ & $32 \%$ \\
7 & CF 3 Ph & $0.19 \mathrm{M}$ & $42 \%$ \\
8 & Xylene & $0.50 \mathrm{M}$ & $35 \%$ \\
9 & Toluene & $0.19 \mathrm{M}$ & $51 \%$ \\
10 & Toluene & $0.075 \mathrm{M}$ & $65 \%$ \\
11 & Toluene & $0.019 \mathrm{M}$ & $69 \%$ \\
12 & Toluene & $0.075 \mathrm{M}$ & $62 \%$
\end{tabular}

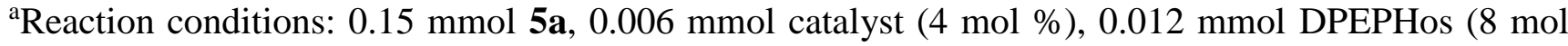
$\%), 0.225 \mathrm{mmol} 6 \mathrm{6a}$ (1.5 equiv), $0.225 \mathrm{mmol} \mathrm{NaO} t \mathrm{Bu}\left(1.5\right.$ equiv), solvent, $3 \mathrm{~h}, 80{ }^{\circ} \mathrm{C}$, yield was determined by GC-MS; ${ }^{\text {b } 0.40 ~ m m o l ~ 5 a, ~} 0.52 \mathrm{mmol}$ 1-bromooctyne (6a) (1.3 equiv), $0.52 \mathrm{mmol} \mathrm{NaOt} \mathrm{Bu}$ (1.3 equiv), $0.020 \mathrm{mmol}$ catalyst ( $5 \mathrm{~mol} \%), 0.030 \mathrm{mmol}$ DPEPHos $(7.5 \mathrm{~mol} \%)$, solvent, $3 \mathrm{~h}, 80^{\circ} \mathrm{C}$, isolated yield after column chromatography.

With optimized conditions in hand, we then examined the scope of the reaction. We started with variation of the bromo alkyne 6 (Scheme 2). The required aliphatic bromo acetylenes were readily prepared 
by bromination of terminal alkynes with a slight excess of NBS, in the presence of catalytic $\mathrm{AgNO}_{3} .{ }^{15} \mathrm{In}$ addition to octynyl bromide $\mathbf{6 a}$, the reaction worked well with pentynyl bromides bearing different functional groups in the terminal position, giving products bearing a silyl-protected alcohol (7ad, 67\% yield) a phenyl group (7ae, 64\% yield), a chloride group (7af, 56\%) or a protected alkyne (7ag, 59\%). The tolerance to a halogen atom is particularly interesting, as a Williamson etherification could have been expected in this case. For the first time, bromo acetylenes $\mathbf{6 h - k}$ derived from propargylic alcohols could be used in the oxyalkynylation reaction to produce products 7ah-i. This result was of particular interest when considering the prevalence of hydroxy substituents in bioactive natural products and also constituted a major breakthrough in the field, as propargylic or allylic alcohols had never been obtained in the oxyfunctionalization of alkenes before. Both benzyl and triisopropyl silyl protected groups could be used in the reaction to give tertiary (products 7ah and 7ai) and secondary (products 7aj and 7ak) propargylic alcohols in 63-85\% yield. We then decided to examine secondary alcohols $\mathbf{5 b}$ and $\mathbf{5 c}$ as substrates. ${ }^{16}$ The reaction is especially interesting in this case because the resulting 2,5-disubstituted tetrahydrofurans are often encountered in biologically active natural compounds (Figure 1). 2Phenylpentenol (5b) smoothly reacted with tertiary alkynyl bromide $\mathbf{6 h}$ to deliver trans-substituted tetrahydrofuran $\mathbf{7 b h}$ as the only diastereoisomer in $72 \%$ yield. Alcohol 5c, bearing a propargyl group on the carbinol position, was less reactive and complete conversion could not be achieved. Nonetheless, the oxyalkynylation with octynylbromide $\mathbf{6 a}$ resulted in the formation of the C2-symmetric product 7ca, in $55 \%$ isolated yield and a 87:13 trans selectivity.

Scheme 2: Scope of the oxyalkynylation of $\gamma$-hydroxyalkenes with aliphatic alkynyl bromides. ${ }^{\text {a }}$ 


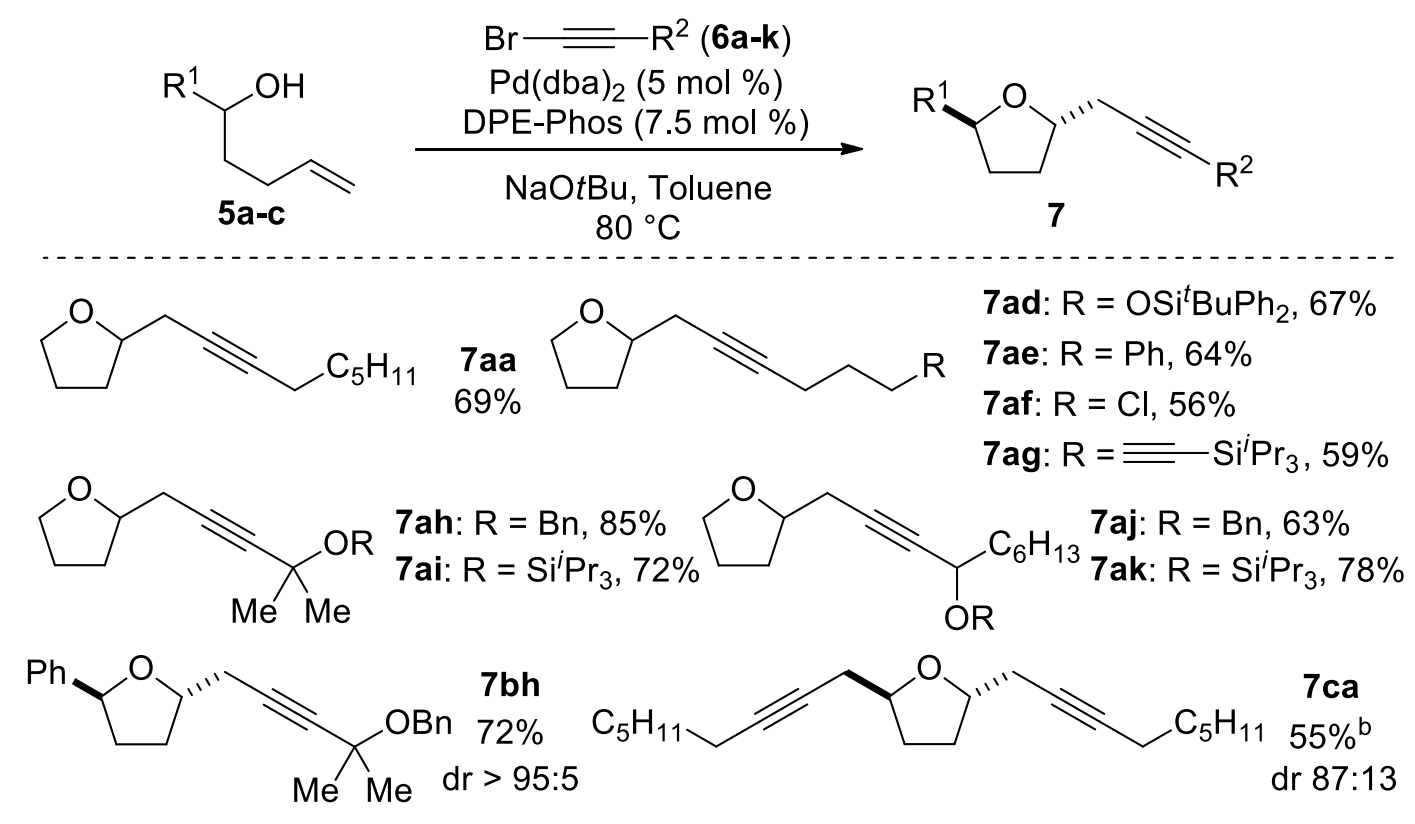

aReaction conditions: $0.40 \mathrm{mmol}$ alcohol 5, $0.52 \mathrm{mmol}$ alkynyl bromide 6 (1.3 equiv), $0.52 \mathrm{mmol}$ $\mathrm{NaO} t \mathrm{Bu}$ (1.3 equiv), $0.020 \mathrm{mmol} \mathrm{Pd(dba)})_{2}(5 \mathrm{~mol} \%), 0.030 \mathrm{mmol}$ DPEPHos $(7.5 \mathrm{~mol} \%), 4.6 \mathrm{~mL}$ toluene, $80{ }^{\circ} \mathrm{C}$, under $\mathrm{N}_{2}$ for 3 hours, isolated yield after column chromatography; ${ }^{\mathrm{b}} 0.040 \mathrm{mmol} \mathrm{Pd}(\mathrm{dba})_{2}$ (10 mol \%), 0.060 mmol DPEPHos (15 mol \%), 15 hours.

The reaction of aliphatic alkynyl bromides with $N$-protected $\gamma$-amino alkenes was then investigated (Scheme 3). ${ }^{17}$ Amines at primary position gave the corresponding 2-propargyl pyrrolidines in $60-77 \%$ yields. In addition to octynyl bromide 6a (product 10aa), the reaction worked well with both bromoacetylenes bearing a protected alcohol or a phenyl group on the terminal position (products 10ad and 10ae) and bromo derivatives of tertiary and secondary propargylic alcohols (products 10ah and 10aj). Amines on a secondary position gave full conversion and high diastereoselectivity in favor of the cis2,5-disubstituted pyrrolidines. The transformation was compatible with both aromatic (product 10ba) and aliphatic substituents (product 10ca) on the secondary position. The presence of a double bond in the lateral chain was well tolerated and compound 10da was isolated in $60 \%$ yield. Polycyclic nitrogen heterocycles constitute the core of a multitude of bioactive natural alkaloids. The potential of the method to access polycyclic systems were consequently examined in more detail. cis-2-Allyl cyclopentyl, cyclohexyl and cycloheptenyl amines 9e-g were good substrates for aminoalkynylation and give access 
to [5,5], [5,6] and [5.7] bicyclic heterocycles (products 10ea, 10fa, 10fl and 10ga). Aminoalkynylation with brominated alkynyl bromide $\mathbf{6 l}$ also worked well to produce amine 10fl, without alkylation of the carbamate. The aminoalkynylation was also highly effective in the case of $N$-Boc protected 2-allyl aniline $(\mathbf{9 h})$, showcasing the possibility of applying our method for the preparation of propargylic indoline heterocycles such as 10ha. Finally, the reaction was not limited to $N$-Boc-protected amines: under the same conditions, $N$-aryl substituted pyrrolidines 10ia and $\mathbf{1 0 j a}$ could be obtained in $79 \%$ and $59 \%$ yield respectively.

Scheme 3: Scope of the oxyalkynylation reaction with N-Boc $\gamma$-aminoxyalkenes. ${ }^{\text {a }}$

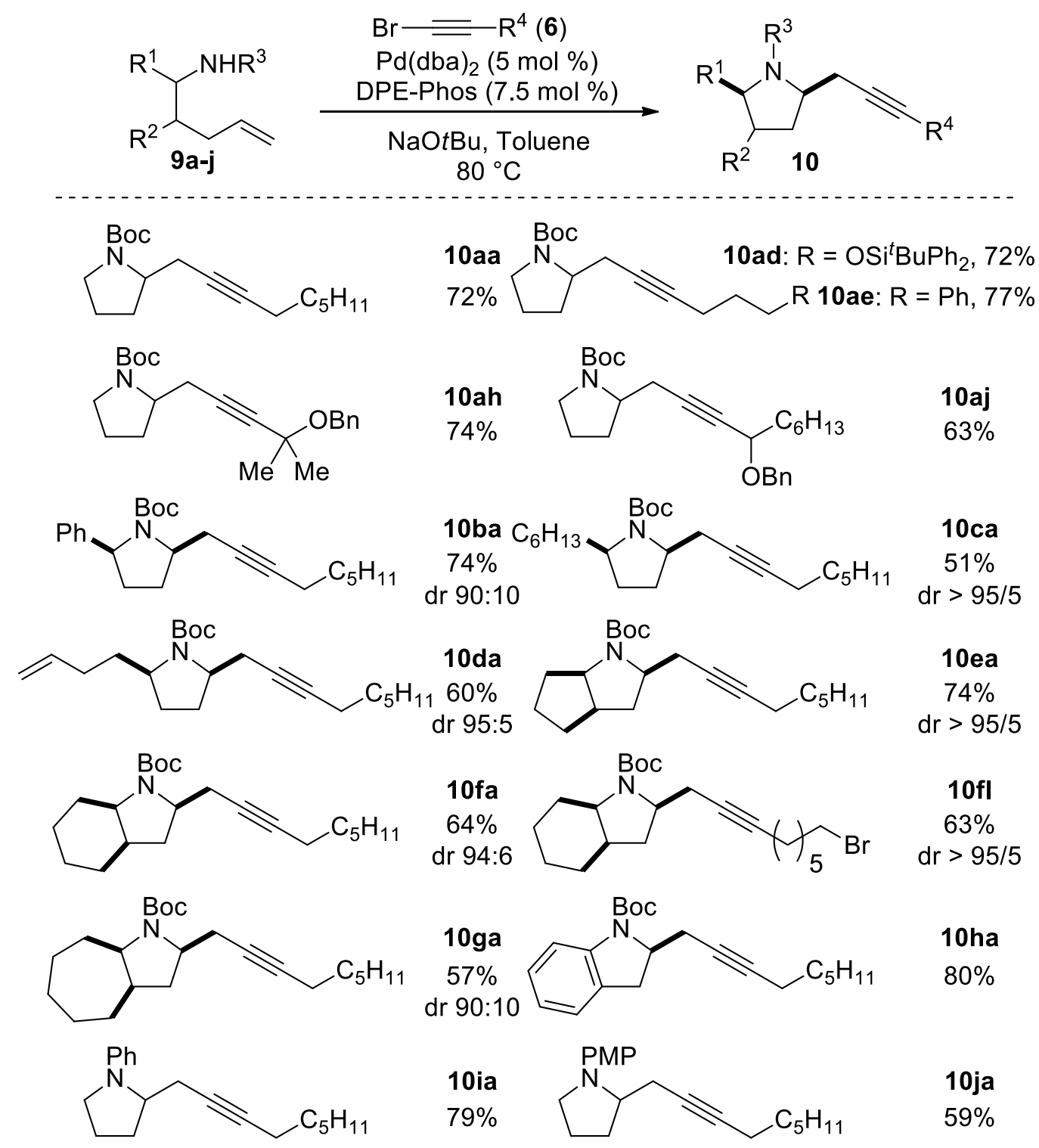




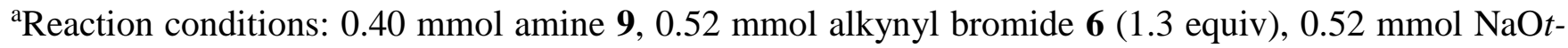
$\mathrm{Bu}$ (1.3 equiv), $0.020 \mathrm{mmol} \mathrm{Pd}(\mathrm{dba})_{2}(5 \mathrm{~mol} \%), 0.030 \mathrm{mmol}$ DPEPHos $(7.5 \mathrm{~mol} \%), 4.6 \mathrm{~mL}$ toluene, $80{ }^{\circ} \mathrm{C}$, under $\mathrm{N}_{2}$ for 3 hours.

Having effectively developed an extension of our method to aliphatic acetylenes, we turned to the reduction of the triple bond to obtain the alkyl chain contained in most natural products. In particular, a one-pot transformation without isolation and purification of the alkyne would provide very efficient access to this class of compounds, especially when considering that the oxy- or aminoalkylation of olefins is still an unknown process. A simple switch of solvent to methanol, addition of $\mathrm{Pd} / \mathrm{C}(5 \mathrm{~mol} \%)$ and hydrogenation under a $\mathrm{H}_{2}$ atmosphere resulted in the smooth and complete in situ reduction to compounds 11aa and 12aa within 12 hours (Scheme 4). ${ }^{18}$ In addition, the reaction worked by simply adding methanol and $\mathrm{Pd} / \mathrm{C}$ to the reaction mixture, but it was much slower (more than 48 hours). Therefore, the removal of toluene prior to the addition of methanol, although not strictly required, was more convenient.

Scheme 4: Oxy- and aminoalkynylation followed by in situ hydrogenation with Pd/C.

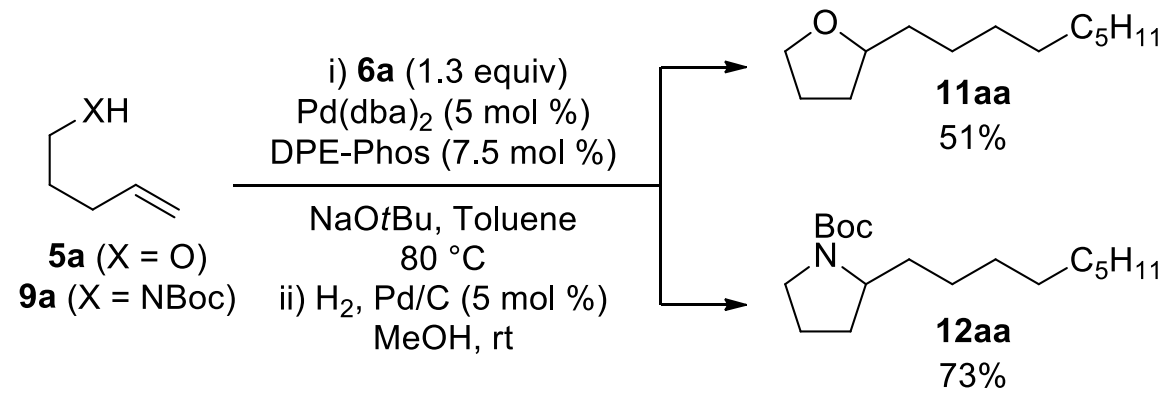

The developed methodology is of high interest because it allows the convergent combination of alcohols or amines and alkynyl bromides of similar complexity, without using a large excess of one of the two partners. In order to gain deeper insight into the reaction mechanism for future improvements, we decided to study the especially challenging coupling of secondary alcohol $\mathbf{5 b}$ with propargylic ether $\mathbf{6 h}$ (Scheme 5). On a $1.85 \mathrm{mmol}$ scale, tetrahydrofuran $\mathbf{7 b h}$ could be isolated in $55 \%$ yield. Three further products originating from alcohol $\mathbf{5 b}$ could also be isolated: recovered $\mathbf{5 b}$ itself (13\% yield), ketone $\mathbf{1 3}$ 
(4\% yield) and hydroxy ketone 14 (12\% yield). In addition, two products derived from alkynyl bromide 6h were obtained: reduced alkyne $\mathbf{1 5}$ (5\% yield) and dimer $\mathbf{1 6}$ (36\% yield).

Scheme 5: Large-scale reaction between alcohol 5b and alkynyl bromide $\mathbf{6 h}$ and identification of side products.

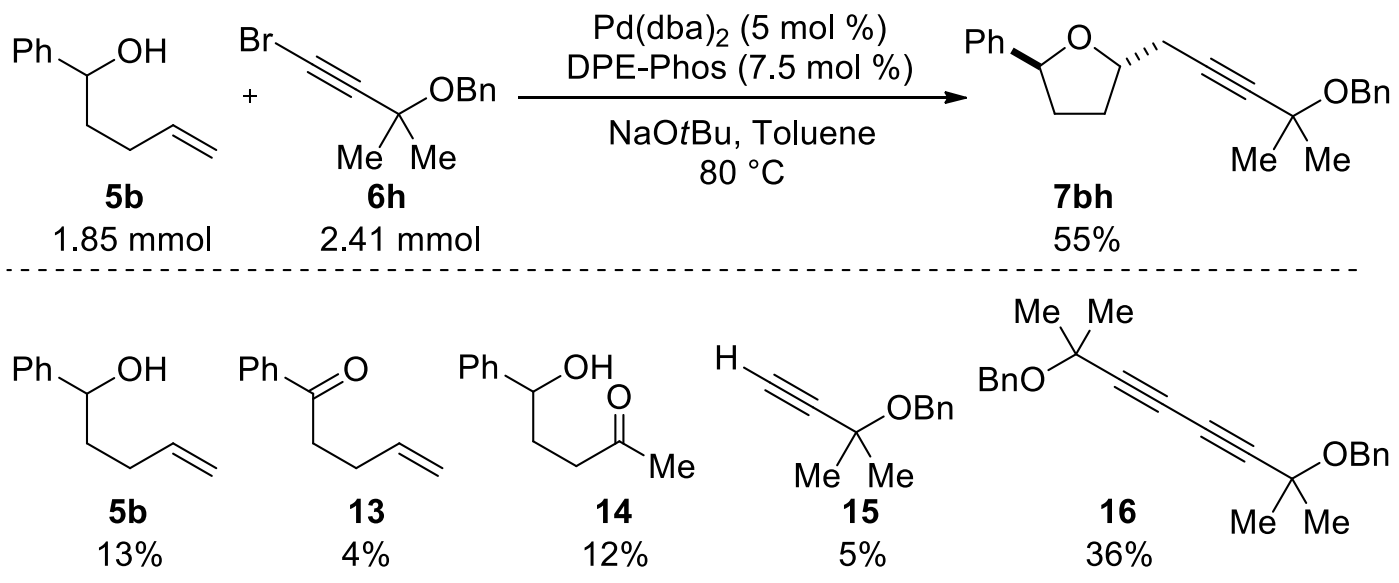

The high number of isolated side products further emphasizes the challenging nature of the oxyalkynylation process. On the other hand, it also constitutes a fascinating footprint for the potential intermediates of the catalytic cycle (Scheme 6). A probable first step would be oxidative addition of a $\operatorname{Pd}(0)$ complex I on alkynyl bromide $\mathbf{6 h}$ to give alkynyl-Pd intermediate II. This kind of organometallic intermediate can potentially undergo ligand exchange to form a bis-alkynyl complex, and subsequent reductive elimination would give the observed diyne $16 .{ }^{19}$ In fact, preventing the homocoupling of the alkynyl bromide is one of the major challenges of the oxyalkynylation process. Ligand exchange on Pd followed by intramolecular oxypalladation on III to give intermediate IV would be in agreement with the excellent trans diastereoselectivity observed, if the two substituents are in pseudo-equatorial position in the transition state $\mathbf{V}$. It allows also rationalizing the cis selectivity observed for pyrrolidines, as in this case a strong $\mathrm{A}^{1,3}$ interaction with the Boc group would make a pseudo axial position of the adjacent substituent more favorable. ${ }^{20}$ Furthermore, a base strong enough to form the alkoxide to allow ligand exchange would be required for this step, as it has been observed during the optimization of the reaction. However, if oxypalladation is too slow, $\beta$-hydride elimination can occur on intermediate III, 
leading to the formation of the observed ketone $\mathbf{1 3}$ and alkyne $\mathbf{1 5}$. Finally, the last step of the catalytic cycle is reductive elimination to give oxyalkynylation product $\mathbf{7 b h}$ and regenerate the active $\mathrm{Pd}(0)$ catalyst I. Again, $\beta$-hydride elimination is possible on intermediate $\mathbf{I V}$, which would lead to the formation of enol ether 17. Although 17 was not isolated from the reaction mixture, hydroxy ketone $\mathbf{1 4}$ could reasonably have been formed during aqueous work-up or on silica gel during column chromatography. ${ }^{21}$ The formation of $\mathbf{1 4}$ is also in agreement with insertion of the olefin into the Pd-O bond from III to form intermediate IV. An alternative mechanism involving first insertion into the Pd-alkynyl bond does not allow rationalizing the formation of $\mathbf{1 4}$.

Scheme 6: Working model for the reaction mechanism of the oxyalkynylation reaction.

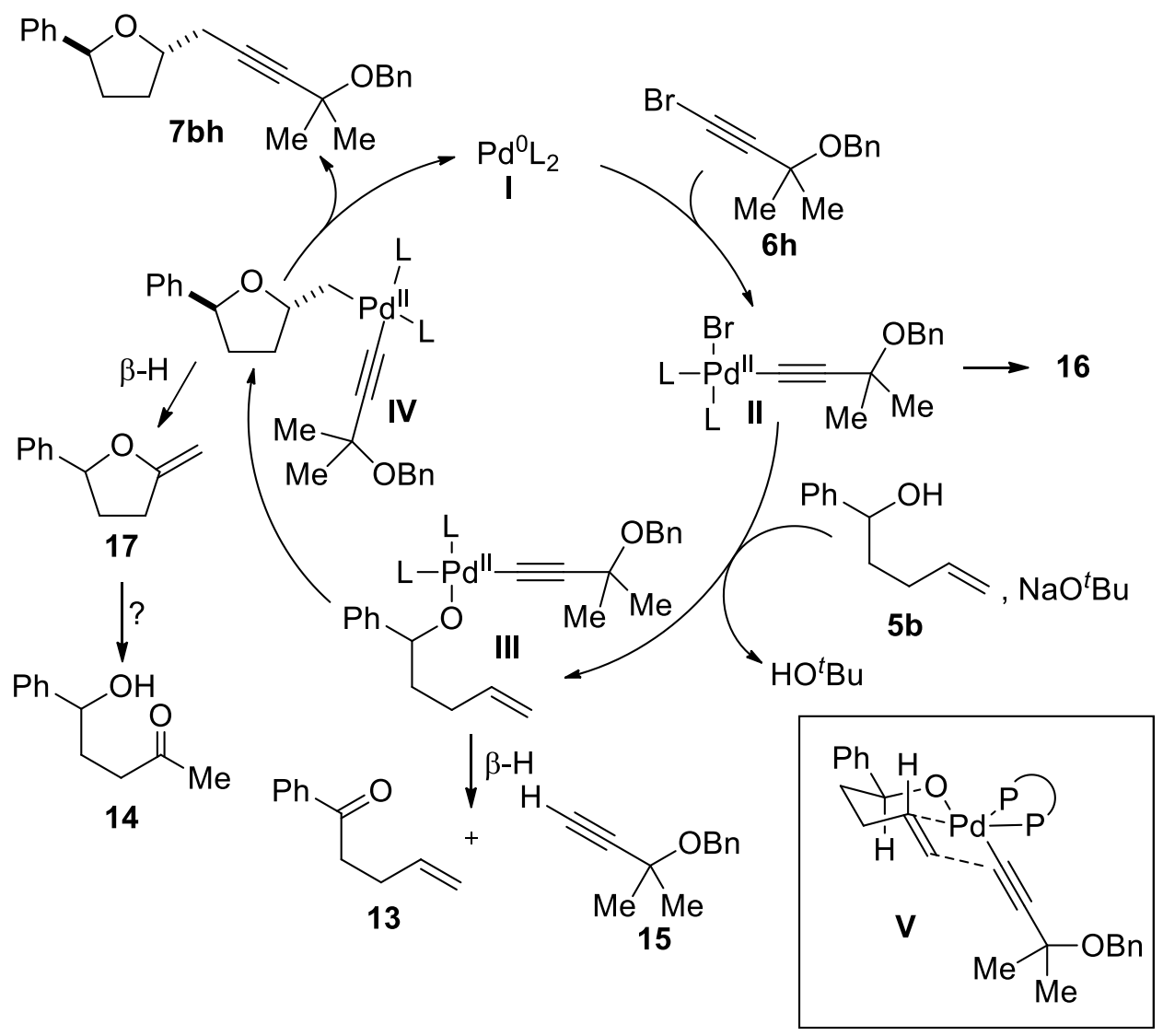

When considering the complexity of the reaction, the required reaction temperature, the short reaction time and the high sensitivity to air, obtaining a precise kinetic profile for the reaction constitutes a formidable challenge. Nevertheless, interesting preliminary results were already obtained by studying the effect of reagents stoichiometry on the rate of formation of oxyalkynylation product 7bh (Figure 2). 
Although the many side reactions does not allow a better understanding of the reaction mechanism, ${ }^{22}$ important practical conclusions could already be drawn from these experiments: 1) Increasing the excess of alkynyl bromide only accelerate slightly the reaction and do not lead to a significant increase in yield. Furthermore, the alkynyl bromide was not completely consumed in the case the reaction had stopped before completion. 2) In the presence of a large excess of base, product formation became much slower. As no extensive decomposition of starting material $\mathbf{5 b}$ and $\mathbf{6 h}$ was observed, this outcome is probably due to catalyst deactivation. 3) The reaction is accelerated when the catalyst loading is increased and more importantly higher yields of product can be obtained, as for example in the case of the oxyalkynylation of propargylic alcohol 5c (Scheme 2, yield with 5 mol\% catalyst: $21 \%$ yield, with 10 mol\% catalyst 55\%). Taken together, these results indicate that catalyst deactivation is a major issue in the developed process and increasing catalyst stability will be important in the future.

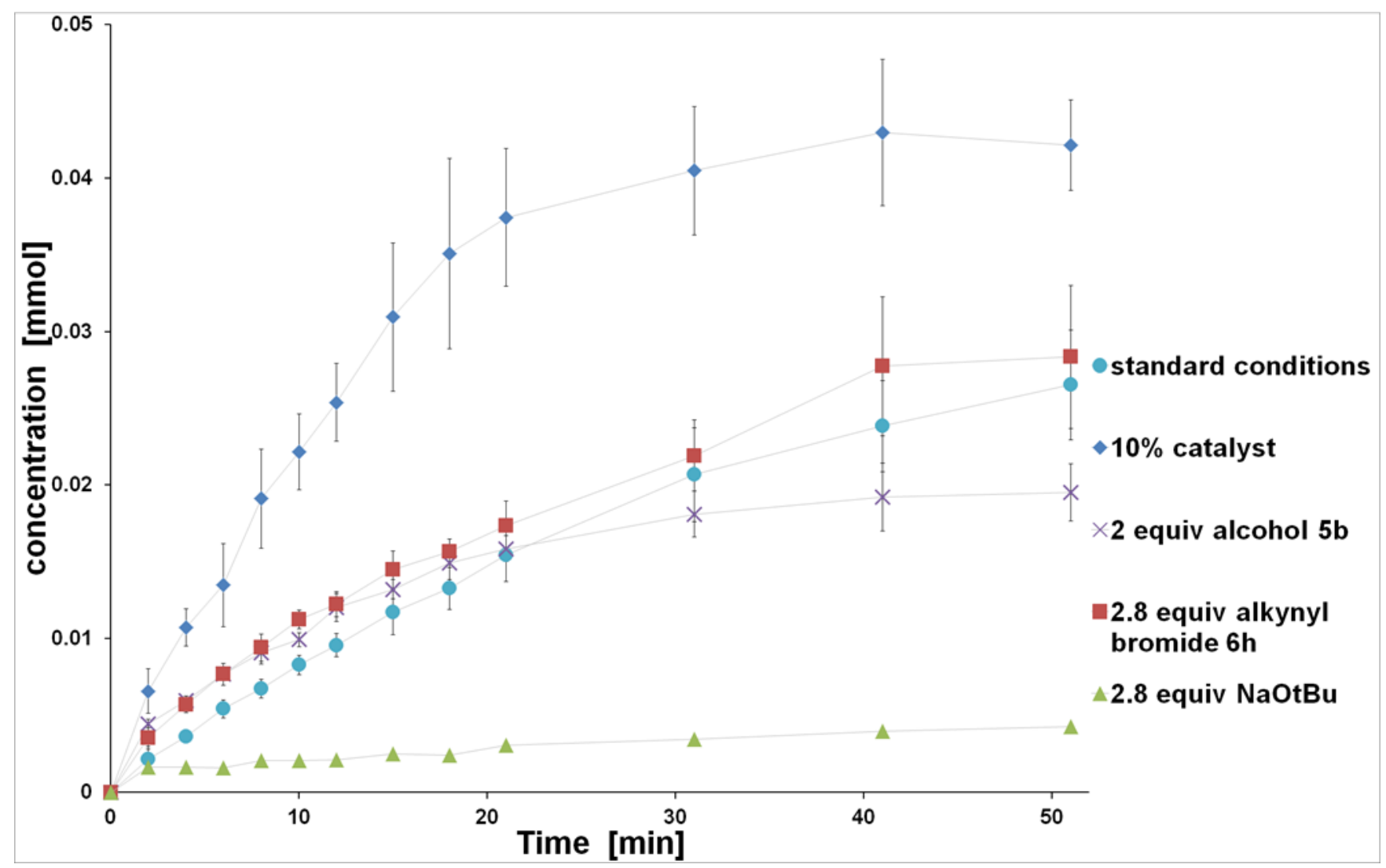

Figure 2. Influence of reagent stoichiometry on the formation of tetrahydrofuran $\mathbf{7 b h}$.

\section{Conclusion}


In conclusion, we have described the first examples of intramolecular oxy- and aminoalkynylation of alkenes using aliphatic bromoacetylenes. The successful use of functionalized acetylenes in particular was unprecedented for the functionalization of olefins and led to a highly convergent synthesis of important tetrahydrofuran and pyrrolidine building blocks for organic synthesis. The obtained products can be easily hydrogenated in a one-pot transformation to give alkyl-substituted furans and pyrrolidines. A careful study of the side products formed during the reaction finally led to a first speculative model for the mechanism of the oxyalkynylation process.

\section{Experimental Section}

\section{1-Phenylpent-4-en-1-ol (5b)}

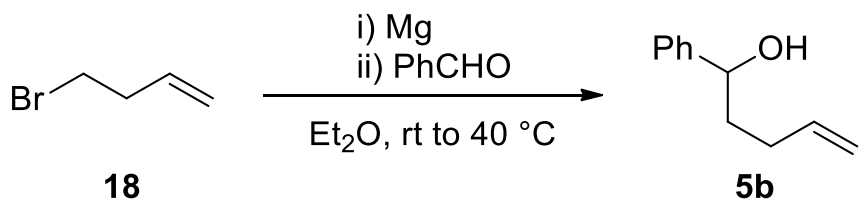

Following a reported procedure, ${ }^{16 a}$ a solution of 4-bromobutene $(\mathbf{1 8})(2.30 \mathrm{~mL}, 22.8 \mathrm{mmol}, 1.15$ equiv) in $\mathrm{Et}_{2} \mathrm{O}(9 \mathrm{~mL})$ was added dropwise to a suspension of $\mathrm{Mg}$ turnings (972 $\mathrm{mg}, 40.0 \mathrm{mmol}, 2.05$ equiv) in $\mathrm{Et}_{2} \mathrm{O}(18 \mathrm{~mL})$ at $\mathrm{rt}$. The mixture was then stirred at $\mathrm{rt}$ for $1 \mathrm{~h}$ and further refluxed for $1 \mathrm{~h}$. A solution of benzaldehyde (2.00 mL, $20.0 \mathrm{mmol}, 1.0$ equiv) in ( $9 \mathrm{~mL})$ was then added dropwise and the mixture was refluxed for $2 \mathrm{~h}$. It was then poured onto ice (ca. $10 \mathrm{~g}$ ) and treated by dropwise addition of $\mathrm{HCl}$ (aqueous solution 2.0 M). The two layers were separated and the aqueous one was extracted with $\mathrm{Et}_{2} \mathrm{O}(2 \times 20 \mathrm{~mL})$. The combined organic layers were washed with aqueous $\mathrm{NaHCO}_{3}$ (saturated solution, $20 \mathrm{~mL}$ ) and brine, dried over $\mathrm{MgSO}_{4}$, filtered and the solvent was removed in vacuo. Purification by column chromatography $\left(\mathrm{SiO}_{2}\right.$, pentane/EtOAc 95/5) afforded benzyl alcohol $\mathbf{5 b}$ as a colorless oil (1.96 g, $12.1 \mathrm{mmol}, 60 \%$ yield). $\mathrm{R}_{\mathrm{f}} 0.30$ (Hexane/EtOAc 20/3); ${ }^{1} \mathrm{H}$ NMR (400 MHz, $\left.\mathrm{CDCl}_{3}\right) \delta$ 7.38-7.33 (m, $3 \mathrm{H}), 7.29(\mathrm{~m}, 2 \mathrm{H}), 5.85(\mathrm{ddt}, 1 \mathrm{H}, J=16.9,10.2,6.6 \mathrm{~Hz}), 5.05$ (ddd, $1 \mathrm{H}, J=17.1,3.4,1.6 \mathrm{~Hz}$ ), $4.99(\mathrm{ddd}, J=10.1,3.1,1.2 \mathrm{~Hz}), 4.70(\mathrm{ddd}, 1 \mathrm{H}, J=7.9,5.5,3.4 \mathrm{~Hz}), 2.15$ (m, $2 \mathrm{H}), 1.97-1.75$ (m, $3 \mathrm{H})$; ${ }^{13} \mathrm{C}$ NMR $\left(101 \mathrm{MHz}, \mathrm{CDCl}_{3}\right) \delta 144.6,138.1,128.5,127.6,125.9,114.9,74.0,38.0,30.0 ;$ IR 3359 (br, 
w), $2932(w), 1721(w), 1721(w), 1642(w), 1603(w), 1591(w), 1493(w), 1453(w), 1416(w), 1416$

(w), $1400(w), 1305(w), 1270(w), 1239(w), 1239(w), 1200(w), 1200(w), 1175(w), 1104(w), 1061$

(m), $1023(\mathrm{~m}), 1013(\mathrm{~m}), 913(\mathrm{~m}), 760(\mathrm{~m}), 701(\mathrm{~s}), 675(\mathrm{~m}), 668(\mathrm{~m}), 667(\mathrm{~m}), 650(\mathrm{~m}), 638(\mathrm{~m}), 629$

(w), $616(w), 606(w)$. The values for the characterization of $\mathbf{5 b}$ correspond to the ones reported in literature. $^{16 \mathrm{a}}$

\section{Tetradec-1-en-7-yn-5-ol (5c)}

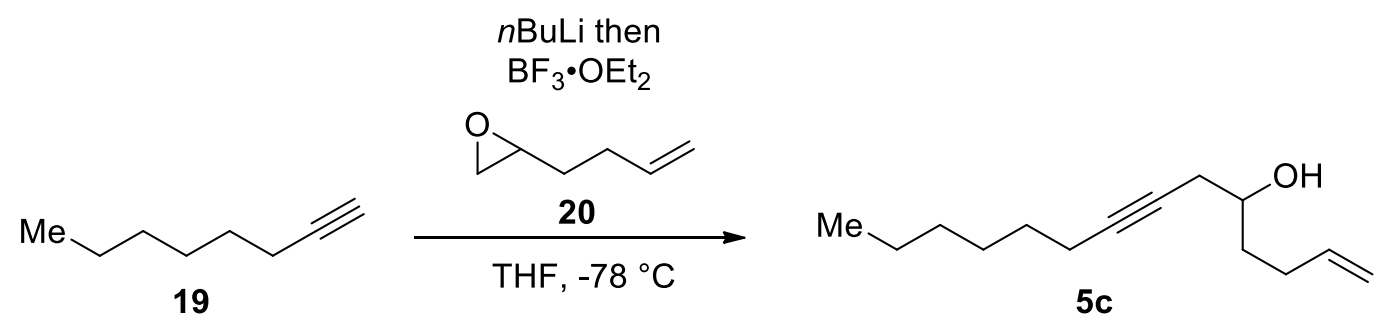

Following a reported procedure, ${ }^{16 \mathrm{~b}}$ 1-octyne $(\mathbf{1 9})(1.94 \mathrm{~mL}, 13.0 \mathrm{mmol}, 1.3$ equiv.) was dissolved in THF (20 mL) and $n \operatorname{BuLi}\left(2.5 \mathrm{M}\right.$ in hexane, $4.8 \mathrm{~mL}, 12 \mathrm{mmol}, 1.2$ equiv.) was added at $-78^{\circ} \mathrm{C}$. The resulting mixture was stirred for $15 \mathrm{~min}$ at this temperature and then warmed to $0{ }^{\circ} \mathrm{C}$ and stirred for 1 h. A solution of epoxide 20 (1.13 mL, $10.0 \mathrm{mmol}, 1.0$ equiv.) in THF (5 mL) was added with stirring at $-78{ }^{\circ} \mathrm{C}$, followed by $\mathrm{BF}_{3} \cdot \mathrm{Et}_{2} \mathrm{O}$ (freshly ditilled on $\mathrm{CaH}_{2}, 1.52 \mathrm{~mL}, 12.0 \mathrm{mmol}, 1.2$ equiv.). After $7 \mathrm{~h}$, the reaction was quenched with aqueous $\mathrm{NH}_{4} \mathrm{Cl}$ (saturated solution, $30 \mathrm{~mL}$ ). Upon warming to $\mathrm{rt}$, the aqueous layer was extracted with $\mathrm{Et}_{2} \mathrm{O}(3 \times 20 \mathrm{~mL})$. The combined organic layers were washed with brine, dried over $\mathrm{MgSO}_{4}$ and the solvent was removed in vacuo. Purification by column chromatography $\left(\mathrm{SiO}_{2}\right.$, Pentane/Et $\left.2 \mathrm{O} 10 / 1\right)$ afforded secondary alcohol 5c as a colorless oil (1.07 g, $5.13 \mathrm{mmol}$, $51 \%$ yield). $\mathrm{R}_{\mathrm{f}} 0.56$ (Hexane/EtOAc 5/1); ${ }^{1} \mathrm{H}$ NMR (400 MHz, $\left.\mathrm{CDCl}_{3}\right) \delta 5.83$ (ddt, $1 \mathrm{H}, J=16.9,10.2$, $6.6 \mathrm{~Hz}), 5.05(\mathrm{dq}, 1 \mathrm{H}, J=17.1,1.5 \mathrm{~Hz}), 4.97(\mathrm{ddd}, 1 \mathrm{H}, J=10.0,2.5,1.5 \mathrm{~Hz}), 3.71$ (dddd, $1 \mathrm{H}, J=$ 11.6, 6.5, 5.1, 5.1 Hz, $1 \mathrm{H}), 2.41$ (dddd, $1 \mathrm{H}, J=16.4,4.7,2.3,2.3 \mathrm{~Hz}$ ), 2.29 (dddd, $J=16.1,6.5,2.0$, $2.0 \mathrm{~Hz}), 2.25-2.09(\mathrm{~m}, 2 \mathrm{H}), 2.17(\mathrm{tt}, 2 \mathrm{H}, J=7.0,2.3 \mathrm{~Hz}), 1.95(\mathrm{~d}, 1 \mathrm{H}, J=5.0 \mathrm{~Hz}), 1.62(\mathrm{dt}, J=8.0$, $6.5 \mathrm{~Hz}$ ), 1.49 (quint, $2 \mathrm{H}, J=6.9 \mathrm{~Hz}), 1.42-1.33(\mathrm{~m}, 2 \mathrm{H}), 1.33-1.23(\mathrm{~m}, 4 \mathrm{H}), 0.89$ (t, $3 \mathrm{H}, J=6.8 \mathrm{~Hz})$; ${ }^{13} \mathrm{C}$ NMR $\left(101 \mathrm{MHz}, \mathrm{CDCl}_{3}\right) \delta 138.2,114.8,75.8,69.6,65.8,35.3,31.3,29.9,28.9,28.5,27.8,22.5$, 
18.7, 14.0; IR 3374 (w), 3080 (w), 2956 (m), 2931 (s), 2872 (w), 2858 (m), 1642 (w), 1467 (w), 1466

(w), $1455(\mathrm{w}), 1436(\mathrm{w}), 1418(\mathrm{w}), 1331(\mathrm{w}), 1120(\mathrm{w}), 1119(\mathrm{w}), 1081(\mathrm{w}), 1080(\mathrm{w}), 1062(\mathrm{w}), 1061$

(w), 1026 (w), $994(w), 912(s)$; HRMS (ESI) calcd for $\mathrm{C}_{14} \mathrm{H}_{25} \mathrm{O}^{+}[\mathrm{M}+\mathrm{H}]^{+}$209.1900; found 209.1903.

\section{Tert-butyl pent-4-enylcarbamate (9a)}

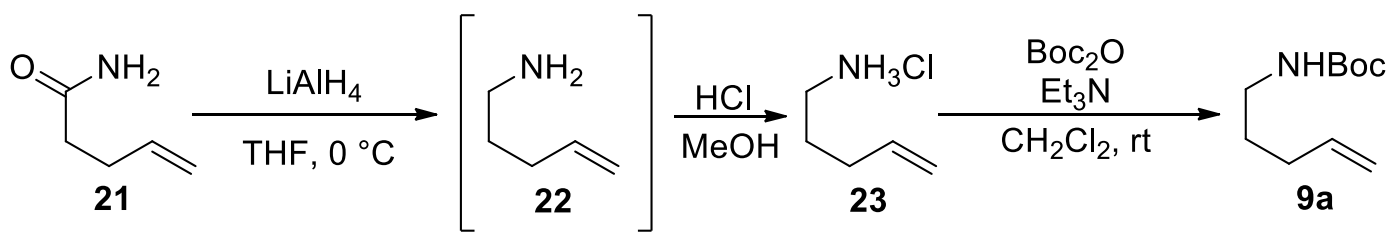

Following a reported procedure, ${ }^{17 \mathrm{f}}$ a suspension of $\mathrm{LiAlH}_{4}(1.72 \mathrm{~g}, 45.1 \mathrm{mmol}, 1.7 \mathrm{equiv})$ in $\mathrm{Et}_{2} \mathrm{O}(45 \mathrm{~mL})$ was slowly added to a solution of 4-pentenamide (21) (2.65 g, $26.5 \mathrm{mmol}, 1.0$ equiv) in $\mathrm{Et}_{2} \mathrm{O}(26 \mathrm{~mL})$ at $0{ }^{\circ} \mathrm{C}$. The resulting mixture was stirred at $\mathrm{rt}$ overnight and then diluted with $\mathrm{Et}_{2} \mathrm{O}(300$ $\mathrm{mL})$. Aqueous $\mathrm{NaOH}(10.0 \mathrm{M})$ was cautiously added dropwise, until complete precipitation of the insoluble materials. After filtration, the solids were washed with $\mathrm{Et}_{2} \mathrm{O}(3 \times 100 \mathrm{~mL})$. The combined organic layers were dried over $\mathrm{MgSO}_{4}$, filtered and the solvent was removed in vacuo. Purification by column chromatography $\left(\mathrm{SiO}_{2}, \mathrm{CH}_{2} \mathrm{Cl}_{2} / \mathrm{ULTRA} 95 / 5\right.$ to 50/50) afforded 4-pentenamine (22 as a colorless oil (0.907 g, $10.5 \mathrm{mmol}, 40 \%$ yield). An impoved yield was obtained when $\mathrm{HCl}$ in $\mathrm{MeOH}$ (1.25 M, ca. 9 $\mathrm{mL}$ ) was added under stirring to the etheral solution of the amine. In this case, removal of the solvent in vacuo afforded the 4-pentenamine hydrochloride (23) as a colorless solid (930 $\mathrm{mg}, 7.64 \mathrm{mmol}, 81 \%$ yield).

Following a slightly modified version of a reported procedure, ${ }^{17 \mathrm{~d}} \mathrm{Et}_{3} \mathrm{~N}(3.25 \mathrm{~mL}, 23.4 \mathrm{mmol}, 2.2$ equiv) was added to a solution of $\mathrm{Boc}_{2} \mathrm{O}\left(2.55 \mathrm{~g}, 11.7 \mathrm{mmol}, 1.1\right.$ equiv) in $\mathrm{CH}_{2} \mathrm{Cl}_{2}(16 \mathrm{~mL})$ and the mixture was stirred at $0{ }^{\circ} \mathrm{C}$ for 5 min. 4-Pentenamine (23) (0.907 g, 10.6 mmol, 1.0 equiv) in $\mathrm{CH}_{2} \mathrm{Cl}_{2}(16$ $\mathrm{mL}$ ) was then added at $0{ }^{\circ} \mathrm{C}$ and the resulting mixture was stirred at $\mathrm{rt}$ overnight. The solution was then washed with aqueous citric acid $(0.1 \mathrm{M}, 20 \mathrm{~mL})$. The aqueous layer was extracted with $\mathrm{CH}_{2} \mathrm{Cl}_{2}(3 \times 20$ $\mathrm{mL}$ ); the combined organic layers were washed with aqueous $\mathrm{NaHCO}_{3}$ (saturated solution, $20 \mathrm{~mL}$ ) and brine, dried over $\mathrm{MgSO}_{4}$, filtered and the solvent was removed in vacuo. Purification by column chro- 
matography ( $\mathrm{SiO}_{2}$, Pentane/EtOAc $95 / 5$ to $80 / 20$ ) afforded protected pentenamine 9a as a pale yellow oil (1.73 g, 9.33 mmol, 88\% yield). $\mathrm{R}_{\mathrm{f}} 0.32$ (Hexane/EtOAc 20/2); ${ }^{1} \mathrm{H}$ NMR $\left(400 \mathrm{MHz}, \mathrm{CDCl}_{3}\right) \delta 5.80$ (ddt, $1 \mathrm{H}, J=16.9,10.2,6.7 \mathrm{~Hz}), 5.03(\mathrm{dq}, 1 \mathrm{H}, J=17.1,1.7 \mathrm{~Hz}), 4.97$ (ddd, $1 \mathrm{H}, J=11.3,2.0,1.1 \mathrm{~Hz}$ ), $4.52(\mathrm{~m}, 1 \mathrm{H}), 3.13(\mathrm{q}, 2 \mathrm{H}, J=6.6 \mathrm{~Hz}), 2.08(\mathrm{~m}, 2 \mathrm{H}), 1.58$ (quint, $1 \mathrm{H}, J=7.4 \mathrm{~Hz}), 1.44(\mathrm{~s}, 9 \mathrm{H}) ;{ }^{13} \mathrm{C}$ NMR (101 MHz, $\left.\mathrm{CDCl}_{3}\right) \delta 155.9,137.7,114.9,78.9,40.0,30.9,29.1,28.3 ;$ IR $3349(\mathrm{w}), 2978(\mathrm{~m})$, $2933(\mathrm{~m}), 2870(\mathrm{w}), 1692(\mathrm{~s}), 1643(\mathrm{w}), 1525(\mathrm{~m}), 1453(\mathrm{w}), 1392(\mathrm{w}), 1367(\mathrm{~m}), 1271(\mathrm{~m}), 1252(\mathrm{~m})$, 1173 (s), 1044 (w), 995 (w), 977 (w), 913 (m), 874 (w), 782 (w), 666 (w), 638 (w). The ${ }^{1}$ H NMR values for the characterization for 9 a correspond to the ones reported in literature. ${ }^{17 \mathrm{~d}}$

\section{Tert-butyl 1-phenylpent-4-enylcarbamate (9b)}

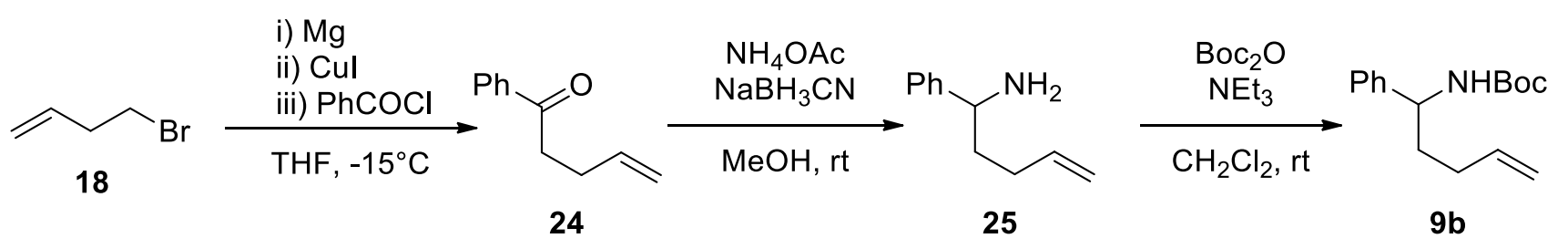

Following a reported procedure, ${ }^{17 \mathrm{e}}$ a solution of 4-bromobutene (18) $(1.6 \mathrm{~mL}, 16 \mathrm{mmol}, 1.0$ equiv) in THF (18 mL) was added dropwise to a suspension of Mg turnings (397 mg, $16.3 \mathrm{mmol}, 1.02$ equiv) in THF ( $2 \mathrm{~mL})$ at $\mathrm{rt}$; the resulting mixture was then stirred at $\mathrm{rt}$ for $1 \mathrm{~h}$. CuI (152 $\mathrm{mg}, 0.798$ mmol, 0.05 equiv) was added to a solution of benzoyl chloride (1.9 mL, 16 mmol, 1.0 equiv) in THF $(17 \mathrm{~mL})$ at $-15{ }^{\circ} \mathrm{C}$ and the resulting mixture was stirred at the same temperature for $10 \mathrm{~min}$. The Grignard reagent previously prepared was then added dropwise over $1 \mathrm{~h}$ at $-15^{\circ} \mathrm{C}$. The mixture was stirred at $-15{ }^{\circ} \mathrm{C}$ for additionally $2 \mathrm{~h}$ and then allowed to warm to rt. THF was removed by distillation under reduced pressure and the residue was treated with $\mathrm{CH}_{2} \mathrm{Cl}_{2}(30 \mathrm{~mL})$ and aqueous $\mathrm{HCl}(1.0 \mathrm{M}, 20 \mathrm{~mL})$. The two layers were separated and the aqueous one was extracted with $\mathrm{CH}_{2} \mathrm{Cl}_{2}(3 \times 30 \mathrm{~mL})$. The combined organic layers were washed with aqueous $\mathrm{NaHCO}_{3}$ (saturated solution), dried over $\mathrm{MgSO}_{4}$, filtered and the solvent was removed in vacuo. Purification by column chromatography $\left(\mathrm{SiO}_{2}, \mathrm{Pen}-\right.$ tane/EtOAc 95/5) afforded ketone 24 as a pale yellow oil (2.44 g, 15.2 mmol, $95 \%$ yield). 
Ketone 24 (2.30 g, $14.3 \mathrm{mmol}, 1.0$ equiv) was dissolved in $\mathrm{MeOH}$ (43 mL). Ammonium acetate (18.0 g, 233 mmol, 16.3 equiv), $\mathrm{NaBH}_{3} \mathrm{CN}$ (1.53 g, $24.4 \mathrm{mmol}, 1.7$ equiv) and activated molecular sieves $4 \AA$ were added and the resulting mixture was stirred at $\mathrm{rt}$ for $24 \mathrm{~h}$. The reaction was then quenched by dropwise addition of aqueous $\mathrm{HCl}(37 \% \mathrm{w} / \mathrm{v}$, ca. $20 \mathrm{~mL})$ until $\mathrm{pH} 2$. The organic solvent was removed under reduced pressure and the residue diluted with water $(15 \mathrm{~mL})$. The aqueous layer was washed with $\mathrm{Et}_{2} \mathrm{O}(2 \times 35 \mathrm{~mL})$ and treated by addition of solid $\mathrm{KOH}$ until $\mathrm{pH} 12$. It was then extracted with $\mathrm{Et}_{2} \mathrm{O}$ (4 x $25 \mathrm{~mL}$ ), the combined organic layers were dried over $\mathrm{KOH}$, filtered and the solvent was removed in vacuo to afford secondary amine 25 as a colorless oil (1.44 g, 8.95 mmol 62\% yield), which was not further purified.

Secondary amine 25 (0.564 g, 3.50 mmol, 1.0 equiv) was dissolved in $\mathrm{CH}_{2} \mathrm{Cl}_{2}(10.5 \mathrm{~mL}) . \mathrm{Et} 3 \mathrm{~N}$ (1.1 mL, $7.7 \mathrm{mmol}, 2.2$ equiv) was added and the solution was cooled to $0{ }^{\circ} \mathrm{C}$. $\mathrm{Boc}_{2} \mathrm{O}(0.840 \mathrm{~g}, 3.85$ mmol, 1.1 equiv) was added in two portions and the resulting mixture was stirred at rt overnight. The solution was then washed with aqueous citric acid $(0.1 \mathrm{M}, 10 \mathrm{~mL})$. The aqueous layer was extracted with $\mathrm{CH}_{2} \mathrm{Cl}_{2}(3 \times 12 \mathrm{~mL})$; the combined organic layers were washed with aqueous $\mathrm{NaHCO}_{3}$ (saturated solution, $12 \mathrm{~mL}$ ) and brine, dried over $\mathrm{MgSO}_{4}$, filtered and the solvent was removed in vacuo. Purification by column chromatography $\left(\mathrm{SiO}_{2}\right.$, Pentane/EtOAc $98 / 2$ to $\left.95 / 5\right)$ afforded protected amine $\mathbf{9 b}$ as a colorless solid (0.815 g, $3.11 \mathrm{mmol}, 89 \%$ yield). R 0.51 (Pentane/EtOAc 20/3); ${ }^{1} \mathrm{H}$ NMR (400 MHz, $\left.\mathrm{CDCl}_{3}\right) \delta 7.33(\mathrm{~m}, 2 \mathrm{H}), 7.25(\mathrm{~m}, 3 \mathrm{H}), 5.81(\mathrm{ddt}, 1 \mathrm{H}, J=16.8,10.2,6.5 \mathrm{~Hz}), 5.01(\mathrm{ddd}, J=16.1,3.5$, 2.0 Hz), 4.99-4.96 (m, $1 \mathrm{H}), 4.78(\mathrm{~m}, 1 \mathrm{H}), 4.64(\mathrm{~m}, 1 \mathrm{H}), 2.09$ (m, $2 \mathrm{H}), 1.78$ (m, $2 \mathrm{H}), 1.42$ (s, $9 \mathrm{H})$; ${ }^{13} \mathrm{C}$ NMR $\left(101 \mathrm{MHz} \mathrm{CDCl}_{3}\right) \delta 155.2,142.7,137.6,128.5,127.2,126.3,115.2,79.3,55.1,36.0,30.4$, 28.4; IR 3382 (w), 3078 (w), 3064 (w), 3030 (w), 3004 (w), 2978 (w), 2933 (w), 2360 (w), 2342 (w), 1685 (s), 1643 (w), 1519 (s), 1452 (w), $1414(w), 1391(w), 1365$ (m), 1321 (w), 1297 (m), 1254 (m), $1213(\mathrm{w}), 1175(\mathrm{~s}), 1122(\mathrm{w}), 1047$ (m), $1026(\mathrm{w}), 1018(\mathrm{w}), 1000(\mathrm{w}), 912(\mathrm{~m}), 868(\mathrm{w}), 779(\mathrm{w}), 765$ (m), $752(\mathrm{~m}), 703$ (s), $686(\mathrm{w}), 670(\mathrm{w}), 660$ (w), 648 (w), 632 (w), $613(\mathrm{w})$; M.p.: 81.9-84. $4^{\circ} \mathrm{C}$. The values for the characterization for $\mathbf{9 b}$ correspond to the ones reported in literature. ${ }^{23}$ 

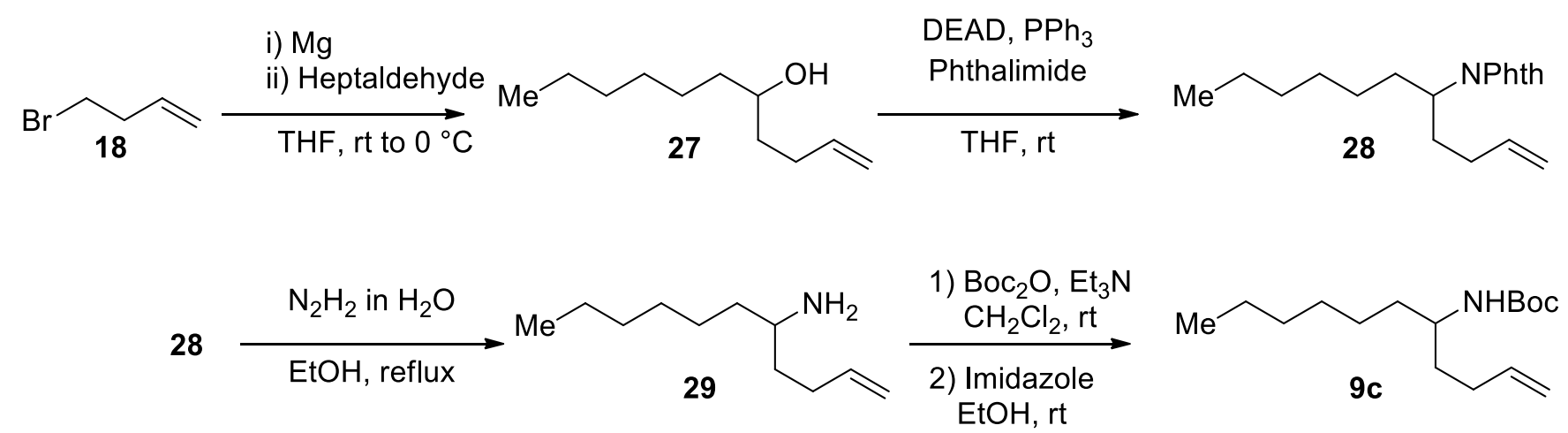

Following a reported procedure, ${ }^{17 \mathrm{~g}}$ 4-bromobutene (18) $(2.0 \mathrm{~mL}, 20 \mathrm{mmol}, 2.5$ equiv.) in THF (10 mL) was added dropwise to a suspension of Mg turnings ( $486 \mathrm{mg}, 20.0 \mathrm{mmol}, 2.5$ equiv.) in THF (2 $\mathrm{mL})$. The resulting mixture was stirred overnight and then a solution of heptaldehyde $(1.1 \mathrm{~mL}, 8.0$ mmol, 1.0 equiv.) in THF $(10 \mathrm{~mL})$ was added dropwise at $0{ }^{\circ} \mathrm{C}$. The reaction was stirred for $3.5 \mathrm{~h}$ and then quenched with aqueous $\mathrm{NH}_{4} \mathrm{Cl}$ (saturated solution). The aqueous layer was extracted with $\mathrm{Et}_{2} \mathrm{O}$ (3 x $20 \mathrm{~mL}$ ). The combined organic layers were washed with brine, dried over $\mathrm{MgSO}_{4}$, filtered and the solvent was removed in vacuo. Purification by column chromatography $\left(\mathrm{SiO}_{2}\right.$, Pentane/EtOAc 98/2) afforded the secondary alcohol 27 as a pale yellow oil (1.05 g, $6.17 \mathrm{mmol}, 77 \%$ yield).

Following a reported procedure, ${ }^{17 \mathrm{c}}$ phthalimide $(1.05 \mathrm{~g}, 7.11 \mathrm{mmol}, 1.4$ equiv.) and triphenyl phosphine (1.87 g, $7.11 \mathrm{mmol}, 1.40$ equiv) were dissolved in THF (37 mL). Secondary alcohol 27 (865 $\mathrm{mg}, 5.08 \mathrm{mmol}, 1.0$ equiv) was added; DEAD (40\% solution in toluene, $3.1 \mathrm{~mL}, 7.11 \mathrm{mmol}, 1.4$ equiv) was then added dropwise at $\mathrm{rt}$ over $20 \mathrm{~min}$. The reaction mixture was stirred at $\mathrm{rt}$ for $24 \mathrm{~h}$. The solvent was evaporated and the mixture was directly purified by column chromatorgraphy $\left(\mathrm{SiO}_{2}\right.$, pentane/EtOAc 20/1) to afford phthalimide $\mathbf{2 8}$ as a pale yellow oil (1.17 g, $3.91 \mathrm{mmol}, 77 \%$ yield).

Phthalimide 28 (1.16 g, 3.86 mmol, 1.0 equiv.) was dissolved in EtOH (34 mL). Hydrazine hydrate $(0.39 \mathrm{~mL}, 8.0 \mathrm{mmol}, 2.07$ equiv. $)$ was added and the mixture was refluxed for $7 \mathrm{~h}$. The mixture was allowed to cool to rt. Concentrated $\mathrm{HCl}(37 \%$ w/w, ca. $10 \mathrm{~mL})$ was added dropwise to quench the reaction and the mixture was filtered through a pad of celite. The aqueous solution was extracted with 
$\mathrm{Et}_{2} \mathrm{O}(2 \times 20 \mathrm{~mL})$ and treated with solid $\mathrm{NaOH}$ until $\mathrm{pH}$ 12. It was then extracted with $\mathrm{CH}_{2} \mathrm{Cl}_{2}(4 \times 50$ $\mathrm{mL}$ ). The combined organic layers were washed with brine and dried over $\mathrm{Na}_{2} \mathrm{SO}_{4}$, filtered and the solvent was removed in vacuo to afford the secondary amine 29 (315 mg, $1.86 \mathrm{mmol}, 48 \%$ yield) as a viscous colorless oil which did not require further purification.

Secondary amine 29 (315 mg, $1.86 \mathrm{mmol}, 1.0$ equiv) was dissolved in $\mathrm{CH}_{2} \mathrm{Cl}_{2}$ (4.3 mL). Et $3 \mathrm{~N}$ (freshly distilled on $\mathrm{CaH}_{2}, 0.65 \mathrm{~mL}, 4.6 \mathrm{mmol}, 2.5$ equiv.) was added and the solution was cooled to $0^{\circ} \mathrm{C}$. Boc $_{2} \mathrm{O}$ (567 mg, $2.60 \mathrm{mmol}, 1.4$ equiv.) was added in two portions and the resulting mixture was stirred at rt overnight. The solution was then washed with aqueous citric acid $(0.1 \mathrm{M}, 4 \mathrm{~mL})$. The aqueous layer was extracted with $\mathrm{CH}_{2} \mathrm{Cl}_{2}(3 \times 10 \mathrm{~mL})$ and the combined organic layers were washed with aqueous $\mathrm{NaHCO}_{3}$ (saturated solution, $10 \mathrm{~mL}$ ) and brine, dried over $\mathrm{MgSO}_{4}$, filtered and the solvent was removed in vacuo. In order to remove the excess of $\mathrm{Boc}_{2} \mathrm{O},{ }^{24}$ crude $\mathrm{N}$-protected amine 9c was dissolved in $\mathrm{EtOH}(7.5 \mathrm{~mL})$ and imidazole was added $(633 \mathrm{mg}, 9.30 \mathrm{mmol}, 5.0$ equiv.). The resulting mixture was stirred for 30 min at $\mathrm{rt}$, then $\mathrm{CHCl}_{3}(18 \mathrm{~mL})$ was added and the mixture was washed with an aqueous $\mathrm{HCl} 1 \%$ solution $\left(2 \times 37 \mathrm{~mL}, 0-5{ }^{\circ} \mathrm{C}\right)$. The combined organic layers were dried over $\mathrm{MgSO}_{4}$, filtered and the solvent was removed in vacuo and the mixture was purified by column chromatography $\left(\mathrm{SiO}_{2}\right.$, Pentane/EtOAc 20/1) to afford the protected secondary amine 9c as a colorless oil (287 mg, $1.07 \mathrm{mmol}$, $57 \%$ yield). $\mathrm{R}_{\mathrm{f}} 0.76$ (Hexane/EtOAc 5/1); ${ }^{1} \mathrm{H} \mathrm{NMR}\left(400 \mathrm{MHz}, \mathrm{CDCl}_{3}\right) \delta 5.81$ (ddt, $1 \mathrm{H}, J=16.9,10.2$, $6.7 \mathrm{~Hz}), 5.01(\mathrm{dq}, 1 \mathrm{H}, J=17.1,1.7 \mathrm{~Hz}), 4.95(\mathrm{ddd}, 1 \mathrm{H}, J=10.1,2.0,1.3 \mathrm{~Hz}), 4.24(\mathrm{~m}, 1 \mathrm{H}), 3.55(\mathrm{~m}$, $1 \mathrm{H}), 2.08(\mathrm{~m}, 2 \mathrm{H}), 1.43(\mathrm{~s}, 9 \mathrm{H}), 1.36-1.22(\mathrm{~m}, 12 \mathrm{H}), 0.87(\mathrm{t}, 3 \mathrm{H}, J=6.7 \mathrm{~Hz}) ;{ }^{13} \mathrm{C} \mathrm{NMR}(101 \mathrm{MHz}$ $\left.\mathrm{CDCl}_{3}\right) \delta 155.6,138.3,114.6,78.8,50.3,35.6,34.8,31.8,30.2,29.2,28.4,25.8,22.6,14.1 ; \mathrm{IR} 3353$ (w), $2978(w), 2957(w), 2931(\mathrm{~m}), 2872(\mathrm{w}), 2859(\mathrm{w}), 1692(\mathrm{~s}), 1642(\mathrm{w}), 1524(\mathrm{~m}), 1506(\mathrm{~m}), 1455$ (w), $1391(w), 1366(\mathrm{~m}), 1266(\mathrm{w}), 1248(\mathrm{w}), 1247(\mathrm{w}), 1173(\mathrm{~s}), 1105(\mathrm{w}), 1045(\mathrm{w}), 1021(\mathrm{w}), 995$ (w), $910(\mathrm{~m}), 857$ (w); HRMS (ESI) calcd for $\mathrm{C}_{16} \mathrm{H}_{32} \mathrm{NO}_{2}{ }^{+}[\mathrm{M}+\mathrm{H}]^{+}$270.2428; found 270.2428.

\section{Nona-1,8-dien-5-ol (30)}




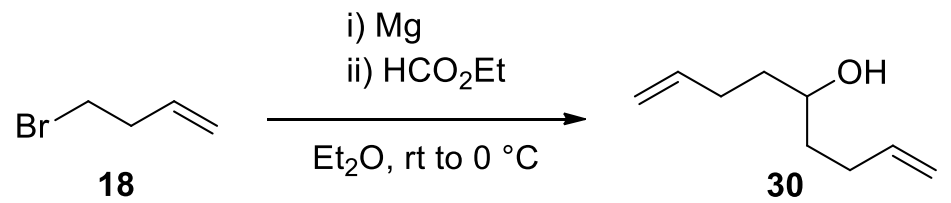

Following a reported procedure, ${ }^{17 \mathrm{~g}}$ a solution of 4-bromobutene (18) $(2.0 \mathrm{~mL}, 20 \mathrm{mmol}, 2.5$ equiv) in THF (16 mL) was added dropwise to a suspension of $\mathrm{Mg}$ turnings (486 $\mathrm{mg}, 20 \mathrm{mmol}, 2.5$ equiv) in THF (2 mL) at rt. After stirring the resulting mixture for $1 \mathrm{~h}$ at $\mathrm{rt}$, it was cooled to $0{ }^{\circ} \mathrm{C}$ and a solution of ethyl formate $(0.65 \mathrm{~mL}, 8.0 \mathrm{mmol}, 1.0$ equiv) in THF $(10 \mathrm{~mL})$ was added dropwise. The mixture was stirred at $\mathrm{rt}$ for $4 \mathrm{~h}$ and then the reaction was quenched with aqueous $\mathrm{NH}_{4} \mathrm{Cl}$ (saturated solution, $30 \mathrm{~mL})$. The two layers were separated and the aqueous one was extracted with $\mathrm{Et}_{2} \mathrm{O}(3 \times 30$ $\mathrm{mL}$ ). The combined organic layers were washed with brine, dried over $\mathrm{MgSO}_{4}$, filtered and the solvent was removed in vacuo. Purification by column chromatography $\left(\mathrm{SiO}_{2}\right.$, Pentane/EtOAc $90 / 10$ to $\left.70 / 30\right)$ afforded secondary alcohol $\mathbf{3 0}$ as a colorless oil (1.03 g, $7.38 \mathrm{mmol}, 92 \%$ yield). $\mathrm{R}_{\mathrm{f}} 0.29$ (Hexane/EtOAc 20/3); ${ }^{1} \mathrm{H}$ NMR (400 MHz, $\left.\mathrm{CDCl}_{3}\right) \delta 5.83(\mathrm{ddt}, 2 \mathrm{H}, J=16.9,10.2,6.7 \mathrm{~Hz}), 5.04$ (ddd, $2 \mathrm{H}$, $J=17.1,3.4,1.7 \mathrm{~Hz}), 4.96(\mathrm{ddd}, 2 \mathrm{H}, J=10.2,3.2,1.5 \mathrm{~Hz}), 3.64(\mathrm{~m}, 1 \mathrm{H}), 2.16(\mathrm{~m}, 4 \mathrm{H}), 1.68-1.45(\mathrm{~m}$, $5 \mathrm{H}) ;{ }^{13} \mathrm{C}$ NMR $\left(101 \mathrm{MHz}, \mathrm{CDCl}_{3}\right) \delta 138.5,114.7,70.9,36.4,30.0 ;$ IR $3359(\mathrm{w}), 3078(\mathrm{w}), 2997$ (w), $2979(w), 2934$ (m), 2869 (w), $2850(w), 1642(w), 1450(w), 1416(w), 1338(w), 1317(w), 1126(w)$, $1126(w), 1080(w), 1061(w), 1053(w), 994(\mathrm{~m}), 947(w), 910(\mathrm{~s}), 736(\mathrm{w}), 650(\mathrm{w}), 650(\mathrm{w}), 636(\mathrm{w})$, $624(w), 614(w)$. The values for the characterization of $\mathbf{3 0}$ correspond to the ones reported in literature. ${ }^{17 g}$

\section{Tert-butyl nona-1,8-dien-5-ylcarbamate (9d)}

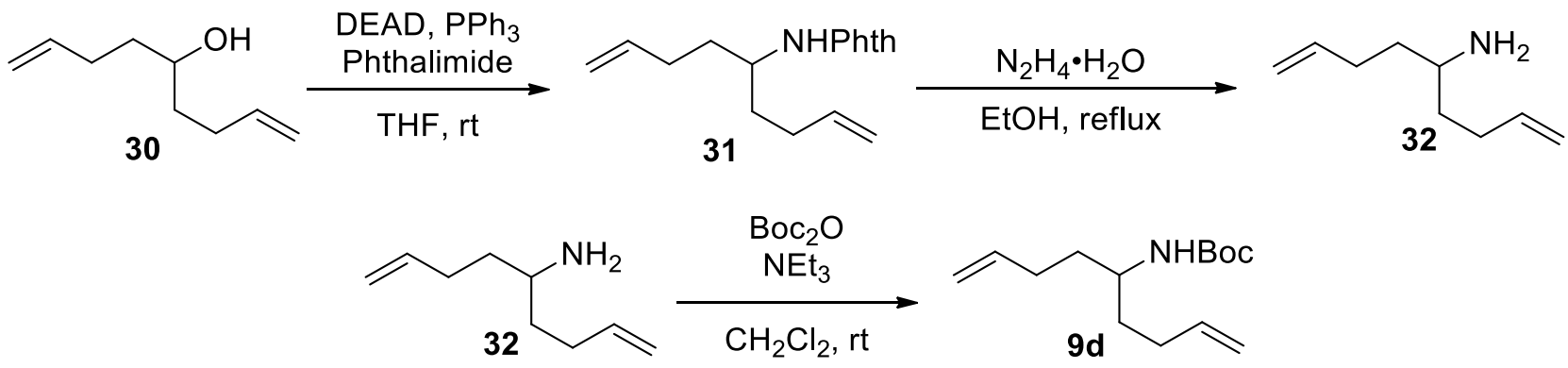


Following a reported procedure, ${ }^{17 \mathrm{c}}$ phthalimide $(1.93 \mathrm{~g}, 13.1 \mathrm{mmol}, 1.40$ equiv) and triphenyl phosphine (3.44 g, $13.1 \mathrm{mmol}, 1.40$ equiv) were dissolved in THF (74 mL). Secondary alcohol 30 (1.59 g, 10.5 mmol, 1.0 equiv) was added; DEAD (40\% solution in toluene, $6.6 \mathrm{~mL}, 15 \mathrm{mmol}, 1.4$ equiv) was then added dropwise at $\mathrm{rt}$ over $20 \mathrm{~min}$. The reaction mixture was stirred at $\mathrm{rt}$ for $23 \mathrm{~h}$. The solvent was removed under reduced pressure and the resulting crude oil was triturated with petroleum ether/Et $2 \mathrm{O}$ (2:1 mixture) until complete precipitation of the solids. The latter were filtered off and washed with the same mixture of solvents. The organic layers were combined and the solvents were removed in vacuo. Purification by column chromatography ( $\mathrm{SiO}_{2}$, Pentane/EtOAc 98/2 to 95/5) afforded phthalimide $\mathbf{3 1}$ as a colorless oil (2.32 g, $8.61 \mathrm{mmol}, 82 \%$ yield).

Phthalimide 31 (2.32 g, $8.61 \mathrm{mmol}, 1.0$ equiv) was dissolved in EtOH (76 mL). Hydrazine hydrate $(0.870 \mathrm{~mL}, 17.8 \mathrm{mmol}, 2.07$ equiv) was added and the mixture was refluxed for $7 \mathrm{~h}$ (during this time a white solid precipitated). The mixture was allowed to cool down to rt and concentrated $\mathrm{HCl}(37 \%$ w/w, ca. $20 \mathrm{~mL}$ ) was added dropwise to quench the reaction. The solvent was removed by distillation under reduced pressure and the residual aqueous solution was washed with $\mathrm{Et}_{2} \mathrm{O}(2 \times 30 \mathrm{~mL})$ and treated with solid $\mathrm{NaOH}$ until $\mathrm{pH}$ 12. It was then extracted with $\mathrm{Et}_{2} \mathrm{O}$ (4 x $100 \mathrm{~mL}$ ). The combined organic layers were washed with brine and dried over $\mathrm{Na}_{2} \mathrm{SO}_{4}$, filtered and the solvent was removed in vacuo. Purification by column chromatography $\left(\mathrm{SiO}_{2}, \mathrm{CH}_{2} \mathrm{Cl}_{2} / \mathrm{ULTRA} 95 / 5\right.$ to 50/50) afforded secondary amine 32 as a colorless oil (0.631 $\mathrm{g}, 4.53 \mathrm{mmol}, 53 \%$ yield).

Secondary amine 32 (0.631 g, $4.53 \mathrm{mmol}, 1.0$ equiv) was dissolved in $\mathrm{CH}_{2} \mathrm{Cl}_{2}(10.5 \mathrm{~mL}) . \mathrm{Et}_{3} \mathrm{~N}$ (1.6 mL, $11 \mathrm{mmol}, 2.5$ equiv) was added and the solution was cooled to $0{ }^{\circ} \mathrm{C}$. Boc $2 \mathrm{O}(1.38 \mathrm{~g}, 6.34$ mmol, 1.4 equiv) was added in two portions and the resulting mixture was stirred at rt overnight. The solution was then washed with aqueous citric acid $(0.1 \mathrm{M}, 10 \mathrm{~mL})$. The aqueous layer was extracted with $\mathrm{CH}_{2} \mathrm{Cl}_{2}(3 \times 10 \mathrm{~mL})$; the combined organic layers were washed with aqueous $\mathrm{NaHCO}_{3}$ (saturated solution, $10 \mathrm{~mL}$ ) and brine, dried over $\mathrm{MgSO}_{4}$, filtered and the solvent was removed in vacuo. Purification by column chromatography ( $\mathrm{SiO}_{2}$, Pentane/EtOAc 95/5 to 90/10) afforded protected amine 9d as a 
colorless solid (0.749 g, 3.13 mmol, 69\% yield). $\mathrm{R}_{\mathrm{f}} 0.59$ (Hexane/EtOAc 20/3); ${ }^{1} \mathrm{H}$ NMR (400 MHz, $\left.\mathrm{CDCl}_{3}\right) \delta 5.81(\mathrm{ddt}, 2 \mathrm{H}, J=16.9,10.2,6.6 \mathrm{~Hz}), 5.02(\mathrm{ddd}, 2 \mathrm{H}, J=17.1,3.2,1.5 \mathrm{~Hz}), 4.96(\mathrm{~d}, 2 \mathrm{H}, J=$ $10.2 \mathrm{~Hz}), 4.25(\mathrm{~m}, 1 \mathrm{H}), 3.59(\mathrm{~m}, 1 \mathrm{H}), 2.10(\mathrm{~m}, 4 \mathrm{H}), 1.56(\mathrm{~m}, 4 \mathrm{H}), 1.44(\mathrm{~s}, 9 \mathrm{H}) ;{ }^{13} \mathrm{C} \mathrm{NMR}(101 \mathrm{MHz}$, $\left.\mathrm{CDCl}_{3}\right) \delta 155.6,138.2,114.8,78.9,49.9,34.8,30.2,28.4$; IR $3439(w), 3341(w), 3077(\mathrm{w}), 3002(\mathrm{w})$, $2978(\mathrm{~m}), 2933$ (m), $2853(\mathrm{w}), 1685$ (s), $1642(\mathrm{w}), 1525(\mathrm{~m}), 1452(\mathrm{w}), 1391(\mathrm{w}), 1366(\mathrm{~m}), 1302(\mathrm{w})$, $1269(\mathrm{w}), 1248$ (m), 1172 (s), 1102 (w), $1046(\mathrm{w}), 1023(\mathrm{w}), 994(\mathrm{w}), 910(\mathrm{~s}), 875(\mathrm{w}), 861(\mathrm{w}), 778$ (w), $748(w), 681(w), 664(w), 644(w), 631(w), 610(w)$; M.p.: found: 38.5-40.5 ${ }^{\circ}$ C; reported: 35.8$36.8^{\circ} \mathrm{C}$. The values for the characterization for $9 \mathrm{~d}$ correspond to the ones reported in literature..$^{25}$

\section{2-Allylcyclopentanol (34)}

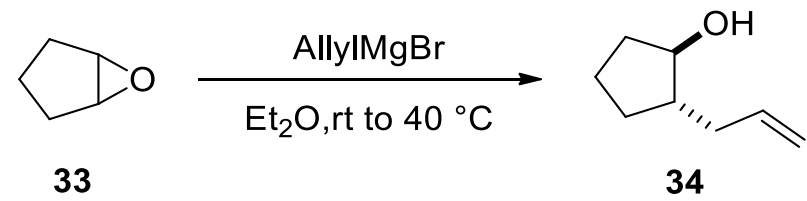

Following a reported procedure, ${ }^{17 \mathrm{a}}$ allyl magnesium bromide $\left(1.0 \mathrm{M}\right.$ in $\mathrm{Et}_{2} \mathrm{O}, 20 \mathrm{~mL}, 20 \mathrm{mmol}$, 2.5 equiv) was diluted with $\mathrm{Et}_{2} \mathrm{O}(20 \mathrm{~mL})$. Cyclopentene oxide $(33)(0.70 \mathrm{~mL}, 8.0 \mathrm{mmol}, 1.0$ equiv $)$ was added dropwise to the resulting solution at rt over $15 \mathrm{~min}$. The mixture was refluxed for $2.5 \mathrm{~h}$. It was the cooled to $0{ }^{\circ} \mathrm{C}$ and then the reaction was quenched by addition of aqueous $\mathrm{NH}_{4} \mathrm{Cl}$ (saturated solution, 20 $\mathrm{mL})$. The two layers were separated and the aqueous one was extracted with $\mathrm{Et}_{2} \mathrm{O}(3 \times 30 \mathrm{~mL})$. The combined organic layers were washed with water $(3 \times 20 \mathrm{~mL})$ and brine, dried over $\mathrm{MgSO}_{4}$, filtered and the solvent was removed in vacuo. 2-Allyl cyclopentanol (34) was obtained as a colorless oil (777 mg, $6.16 \mathrm{mmol}, 77 \%$ yield), which did not require further purification. ${ }^{1} \mathrm{H} \mathrm{NMR}\left(400 \mathrm{MHz}, \mathrm{CDCl}_{3}\right) \delta 5.85$ (dddd, $1 \mathrm{H}, J=17.0,10.1,6.8,6.8 \mathrm{~Hz}$ ), 5.06 (dddd, $J=17.0,2.1,1.4,1.4 \mathrm{~Hz}$ ), 5.00 (ddd, $1 \mathrm{H}, J=10.1$, 1.0, $1.0 \mathrm{~Hz}), 3.86(\mathrm{~m}, 1 \mathrm{H}), 2.18(\mathrm{ddd}, J=14.1,7.0,7.0 \mathrm{~Hz}), 2.03(\mathrm{~m}, 1 \mathrm{H}), 1.91(\mathrm{~m}, 2 \mathrm{H}), 1.80(\mathrm{~m}, 1$ $\mathrm{H}), 1.71(\mathrm{~m}, 1 \mathrm{H}), 1.65-1.51(\mathrm{~m}, 2 \mathrm{H}), 1.49(\mathrm{~d}, 1 \mathrm{H}, J=3.1 \mathrm{~Hz}), 1.22(\mathrm{~m}, 1 \mathrm{H}) ;{ }^{13} \mathrm{C} \mathrm{NMR}(101 \mathrm{MHz}$, $\left.\mathrm{CDCl}_{3}\right) \delta 137.5,115.2,78.0,47.1,37.8,34.0,29.2,21.5$. The values for the characterization for 34 correspond to the ones reported in literature. ${ }^{26}$ 


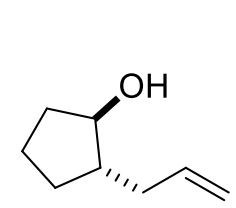

34

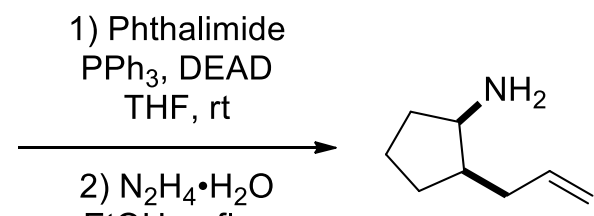

35

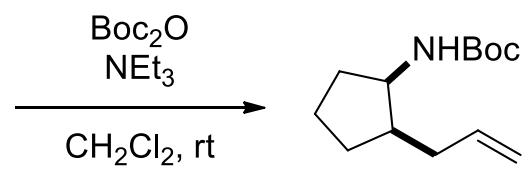

$9 e$

Following a reported procedure, ${ }^{17 \mathrm{c}}$ phthalimide $(1.18 \mathrm{~g}, 8.00 \mathrm{mmol}, 1.3$ equiv) and triphenyl phosphine (2.10 g, $8.00 \mathrm{mmol}, 1.3$ equiv) were dissolved in THF (43 mL). Secondary alcohol 34 (777 mg, 6.16 mmol, 1.0 equiv) was added; DEAD (40\% solution in toluene, $3.9 \mathrm{~mL}, 8.6 \mathrm{mmol}, 1.4$ equiv) was then added dropwise at $\mathrm{rt}$ over $20 \mathrm{~min}$. The reaction mixture was stirred at $\mathrm{rt}$ for $23 \mathrm{~h}$. The solvent was removed under reduced pressure and the resulting crude oil was triturated with $\mathrm{PET} / \mathrm{Et}_{2} \mathrm{O}(2: 1$ mixture) until complete precipitation of the solids. The latter were filtered off and washed with the same mixture of solvents. The organic layers were combined and the solvents were removed in vacuo. Purification by column chromatography $\left(\mathrm{SiO}_{2}\right.$, Pentane/EtOAc 95/5) afforded the corresponding phthalimide as a pale yellow oil (1.21 $\mathrm{g}, 4.73 \mathrm{mmol}, 77 \%$ yield $)$, which was used for the next step without characterization.

The phthalimide obtained in the previous step ( $1.21 \mathrm{~g}, 4.73 \mathrm{mmol}, 1.0$ equiv) was dissolved in EtOH (46 mL). Hydrazine hydrate $(0.48 \mathrm{~mL}, 9.9 \mathrm{mmol}, 2.1$ equiv) was added and the mixture was refluxed for $3 \mathrm{~h}$ (during this time a white solid precipitated). The mixture was allowed to cool down to $\mathrm{rt}$ and concentrated $\mathrm{HCl}(37 \%$ w/w, ca. $20 \mathrm{~mL})$ was added dropwise to quench the reaction. The solvent was removed by distillation under reduced pressure and the residual aqueous solution was washed with $\mathrm{Et}_{2} \mathrm{O}(2 \times 30 \mathrm{~mL})$ and treated with solid $\mathrm{NaOH}$ until pH 12. It was then extracted with $\mathrm{Et}_{2} \mathrm{O}(4 \times 100$ $\mathrm{mL}$ ). The combined organic layers were washed with brine and dried over $\mathrm{Na}_{2} \mathrm{SO}_{4}$, filtered and the solvent was removed in vacuo. Crude amine 35 was obtained as a pale yellow oil (ca $590 \mathrm{mg}, 4.71 \mathrm{mmol}$, quantitative), which was used for the next step without further purification. 
Crude secondary amine 35 (590 g, 4.71 mmol, 1.0 equiv) was dissolved in $\mathrm{CH}_{2} \mathrm{Cl}_{2}$ (18 mL). Et $3 \mathrm{~N}$ (1.9 $\mathrm{mL}, 13 \mathrm{mmol}, 2.7$ equiv) was added and the solution was cooled to $0{ }^{\circ} \mathrm{C}$. $\mathrm{Boc}_{2} \mathrm{O}(1.48 \mathrm{~g}, 6.77 \mathrm{mmol}, 1.4$ equiv) was added in two portions and the resulting mixture was stirred at rt overnight. The solution was then washed with aqueous citric acid $(0.1 \mathrm{M}, 20 \mathrm{~mL})$. The aqueous layer was extracted with $\mathrm{CH}_{2} \mathrm{Cl}_{2}(3 \mathrm{x}$ $20 \mathrm{~mL}$ ); the combined organic layers were washed with aqueous $\mathrm{NaHCO}_{3}$ (saturated solution, $20 \mathrm{~mL}$ ) and brine, dried over $\mathrm{MgSO}_{4}$, filtered and the solvent was removed in vacuo. Purification by column chromatography ( $\mathrm{SiO}_{2}$, Pentane/EtOAc 97/3 to 95/5) afforded N-Boc protected amine 9e as a colorless solid (560 mg, $2.48 \mathrm{mmol}, 53 \%$ yield). $\mathrm{R}_{\mathrm{f}} 0.48$ (Hexane/EtOAc 5/1); Melting Point: 43.0-45.2 ${ }^{\circ} \mathrm{C} ;{ }^{1} \mathrm{H}$ $\operatorname{NMR}\left(400 \mathrm{MHz}, \mathrm{CDCl}_{3}, 65^{\circ} \mathrm{C}\right) \delta 5.82(\mathrm{~m}, 1 \mathrm{H}), 5.02(\mathrm{ddd}, 1 \mathrm{H}, J=17.1,3.4,1.6 \mathrm{~Hz}), 4.97$ (dddd, $1 \mathrm{H}$, $J=10.2,2.1,1.1,1.1 \mathrm{~Hz}), 4.34(\mathrm{~m}, 1 \mathrm{H}), 4.03(\mathrm{~m}, 1 \mathrm{H}), 2.23(\mathrm{~m}, 1 \mathrm{H}), 2.01(\mathrm{~m}, 1 \mathrm{H}), 1.97-1.86(\mathrm{~m}, 2$ H), $1.80(\mathrm{~m}, 1 \mathrm{H}), 1.68(\mathrm{~m}, 1 \mathrm{H}), 1.62-1.46(\mathrm{~m}, 2 \mathrm{H}), 1.46(\mathrm{~m}, 9 \mathrm{H}), 1.36-1.23(\mathrm{~m}, 2 \mathrm{H}) ;{ }^{13} \mathrm{C}$ NMR $(101$ $\left.\mathrm{MHz}, \mathrm{CDCl}_{3}\right) \delta 155.6,137.8,115.2,79.0,54.4,42.6,34.2,32.6,29.4,28.5,21.6 ; \mathrm{IR} 3451(\mathrm{w}), 3336$ (br w), 3332 (w), $3076(\mathrm{w}), 2970(\mathrm{~m}), 2874(\mathrm{w}), 1696(\mathrm{~s}), 1642(\mathrm{w}), 1507(\mathrm{~m}), 1454(\mathrm{w}), 1388(\mathrm{~m}), 1365$ (m), $1311(w), 1248$ (m), 1169 (s), 1089 (w), 1045 (w), 1000 (m), 911 (m), 864 (w); HRMS (ESI) calcd for $\mathrm{C}_{13} \mathrm{H}_{23} \mathrm{NNaO}_{2}{ }^{+}[\mathrm{M}+\mathrm{Na}]^{+}$248.1621; found 248.1626.

\section{2-Allylcyclohexanol (37)}

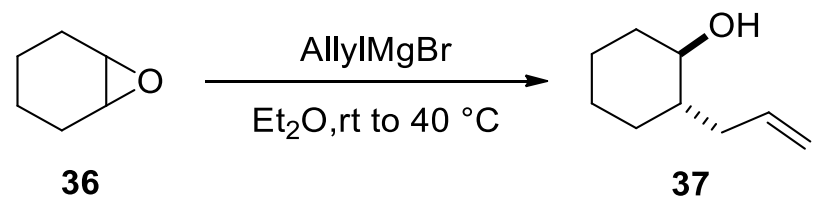

Following a reported procedure, ${ }^{17 \mathrm{a}}$ allyl magnesium bromide $\left(1.0 \mathrm{M}\right.$ in $\mathrm{Et}_{2} \mathrm{O}, 20 \mathrm{~mL}, 20 \mathrm{mmol}$, 3.0 equiv) was diluted with $\mathrm{Et}_{2} \mathrm{O}(16 \mathrm{~mL})$. Cyclohexene oxide 36 (0.67 mL, $6.6 \mathrm{mmol}, 1.0$ equiv) was added dropwise to the resulting solution at rt over $15 \mathrm{~min}$. The mixture was refluxed for $3 \mathrm{~h}$ and then the reaction was quenched by addition of aqueous $\mathrm{NH}_{4} \mathrm{Cl}$ (saturated solution, $30 \mathrm{~mL}$ ). The two layers were separated and the aqueous one was extracted with $\mathrm{Et}_{2} \mathrm{O}(3 \times 30 \mathrm{~mL})$. The combined organic layers were washed with water (3 x $20 \mathrm{~mL}$ ) and brine, dried over $\mathrm{MgSO}_{4}$, filtered and the solvent was removed in 
vacuo. Purification by column chromatography $\left(\mathrm{SiO}_{2}, \mathrm{CH}_{2} \mathrm{Cl}_{2} / \mathrm{MeOH} 99 / 1\right.$ to $\left.96 / 4\right)$ afforded secondary alcohol 37 as a colorless oil (0.838 g, 5.98 mmol, 90\% yield). $\mathrm{R}_{\mathrm{f}} 0.44$ (Hexane/EtOAc 20/3); ${ }^{1} \mathrm{H}$ NMR (400 MHz, $\left.\mathrm{CDCl}_{3}\right) \delta 5.89(\mathrm{ddt}, 1 \mathrm{H}, J=17.2,10.1,7.4 \mathrm{~Hz}), 5.09(\mathrm{~m}, 1 \mathrm{H}), 5.05(\mathrm{~m}, 1 \mathrm{H}), 3.30(\mathrm{~m}, 1 \mathrm{H})$, $2.48(\mathrm{~m}, 1 \mathrm{H}), 2.09-1.92(\mathrm{~m}, 2 \mathrm{H}), 1.79(\mathrm{~m}, 2 \mathrm{H}), 1.65(\mathrm{~m}, 2 \mathrm{H}), 1.43-1.12(\mathrm{~m}, 4 \mathrm{H}), 0.98(\mathrm{~m}, 1 \mathrm{H}) ;{ }^{13} \mathrm{C}$ NMR (101 MHz, $\left.\mathrm{CDCl}_{3}\right) \delta 137.5,115.9,74.5,44.8,37.4,35.5,30.3,25.5,24.9 ;$ IR $3332(\mathrm{w}), 2927$ (s), $2856(\mathrm{~s}), 1639$ (w), 1462 (w), $1462(\mathrm{w}), 1449$ (m), 1415 (w), 1352 (w), 1308 (w), 1234 (w), 1214 (w), $1195(w), 1151(w), 1132$ (w), $1081(w), 1061$ (s), 1037 (s), 997 (w), 965 (w), 965 (w), $940(w), 908$

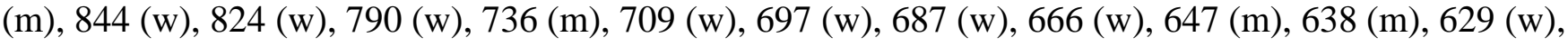
$629(\mathrm{w}), 620(\mathrm{w}), 611(\mathrm{~m})$. The values for the characterization for 37 correspond to the ones reported in literature. ${ }^{27}$

\section{tert-Butyl (2-allylcyclohexyl)carbamate (9f)}

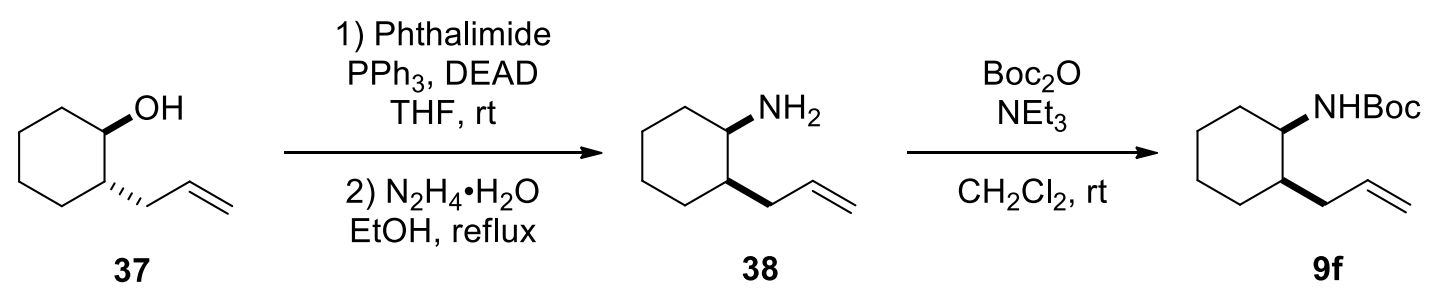

Following a reported procedure, ${ }^{17 \mathrm{c}}$ phthalimide $(1.38 \mathrm{~g}, 9.36 \mathrm{mmol}, 1.3$ equiv) and triphenyl phosphine (2.45 g, $9.36 \mathrm{mmol}, 1.3$ equiv) were dissolved in THF (50 mL). 2-Allyl cyclohexanol (37) (1.00 g, $7.20 \mathrm{mmol}, 1.0$ equiv) was added; DEAD (40\% solution in toluene, $4.6 \mathrm{~mL}, 10 \mathrm{mmol}, 1.4$ equiv) was then added dropwise at $\mathrm{rt}$ over $20 \mathrm{~min}$. The reaction mixture was stirred at $\mathrm{rt}$ for $23 \mathrm{~h}$. The solvent was removed under reduced pressure and the resulting crude oil was triturated with $\mathrm{PET} / \mathrm{Et} 2 \mathrm{O}$ (2:1 mixture) until complete precipitation of the solids. The latter were filtered off and washed with the same mixture of solvents. The organic layers were combined and the solvents were removed in vacuo. Purification by column chromatography $\left(\mathrm{SiO}_{2}\right.$, Pentane/EtOAc $95 / 5$ to 90/10) afforded the corresponding phthalimide as a pale yellow solid (835 $\mathrm{mg}, 3.10 \mathrm{mmol}$, 44\% yield), which was used for the next step without characterization. 
The phthalimide obtained in the previous step (835 mg, $3.10 \mathrm{mmol}, 1.0$ equiv) was dissolved in EtOH $(27 \mathrm{~mL})$. Hydrazine hydrate $(0.32 \mathrm{~mL}, 6.5 \mathrm{mmol}, 2.1$ equiv) was added and the mixture was refluxed for $3 \mathrm{~h}$ (during this time a white solid precipitated). The mixture was allowed to cool down to $\mathrm{rt}$ and concentrated $\mathrm{HCl}(37 \% \mathrm{w} / \mathrm{w}$, ca. $10 \mathrm{~mL})$ was added dropwise to quench the reaction. The solvent was removed by distillation under reduced pressure and the residual aqueous solution was washed with $\mathrm{Et}_{2} \mathrm{O}(2 \times 20 \mathrm{~mL})$ and treated with solid $\mathrm{NaOH}$ until pH 12. It was then extracted with $\mathrm{Et}_{2} \mathrm{O}(4 \times 50 \mathrm{~mL})$. The combined organic layers were washed with brine and dried over $\mathrm{Na}_{2} \mathrm{SO}_{4}$, filtered and the solvent was removed in vacuo. Crude amine 38 was obtained as a pale yellow oil (366 mg, $2.63 \mathrm{mmol}, 85 \%$ yield), which was used for the next step without further purification.

Crude secondary amine 38 (366 mg, $2.63 \mathrm{mmol}, 1.0$ equiv) was dissolved in $\mathrm{CH}_{2} \mathrm{Cl}_{2}(7.7 \mathrm{~mL})$. $\mathrm{Et}_{3} \mathrm{~N}$ (freshly distilled on $\mathrm{CaH}_{2}, 0.80 \mathrm{~mL}, 5.8 \mathrm{mmol}, 2.2$ equiv) was added and the solution was cooled to $0{ }^{\circ} \mathrm{C}$. Boc $2 \mathrm{O}(632 \mathrm{mg}, 2.89 \mathrm{mmol}, 1.1$ equiv) was added in two portions and the resulting mixture was stirred at rt overnight. The solution was then washed with aqueous citric acid $(0.1 \mathrm{M}, 15 \mathrm{~mL})$. The aqueous layer was extracted with $\mathrm{CH}_{2} \mathrm{Cl}_{2}(3 \times 15 \mathrm{~mL})$; the combined organic layers were washed with aqueous $\mathrm{NaHCO}_{3}$ (saturated solution, $15 \mathrm{~mL}$ ) and brine, dried over $\mathrm{MgSO}_{4}$, filtered and the solvent was removed in vacuo. Purification by column chromatography ( $\mathrm{SiO}_{2}$, Pentane/EtOAc 97/3) afforded N-Boc protected amine $9 f$ as a colorless solid (438 mg, $1.83 \mathrm{mmol}, 69 \%$ yield). $\mathrm{R}_{\mathrm{f}} 0.75$ (Hexane/EtOAc 4/1); Melting Point: $46.9-49.2{ }^{\circ} \mathrm{C} ;{ }^{1} \mathrm{H}$ NMR (400 $\left.\mathrm{MHz}, \mathrm{CDCl}_{3}\right) \delta 5.79$ (dddd, $1 \mathrm{H}, J=17.0,10.2,7.3,7.3$ Hz), $5.02(\mathrm{~m}, 1 \mathrm{H}), 4.98(\mathrm{~m}, 1 \mathrm{H}), 4.60$ (br m, $1 \mathrm{H}), 3.83$ (m, $1 \mathrm{H}), 2.09$ (m, $1 \mathrm{H}), 1.91$ (m, $1 \mathrm{H}), 1.77-$ $1.46(\mathrm{~m}, 6 \mathrm{H}), 1.45(\mathrm{~s}, 9 \mathrm{H}), 1.41-1.20(\mathrm{~m}, 2 \mathrm{H}), 1.13(\mathrm{~m}, 1 \mathrm{H}) ;{ }^{13} \mathrm{C} \mathrm{NMR}\left(101 \mathrm{MHz}, \mathrm{CDCl}_{3}\right) \delta 155.4$, 137.1, 115.8, 78.9, 49.2, 39.7, 36.2, 30.8, 28.4, 27.3, 24.3, 21.7. IR 3461 (w), 3348 (br w), 3284 (br w), $3135(w), 3074(w), 2976(w), 2929(\mathrm{~m}), 2859(\mathrm{w}), 2858(w), 1814(w), 1697(\mathrm{~s}), 1643(\mathrm{w}), 1500(\mathrm{~m})$, 1456 (m), 1388 (m), 1365 (m), 1338 (w), $1312(\mathrm{w}), 1247$ (m), 1170 (s), 1106 (w), 1067 (m), 975 (w), $944(\mathrm{w}), 911(\mathrm{~m}), 873(\mathrm{w})$; HRMS (FT-Orbitrap) calcd for $\mathrm{C}_{14} \mathrm{H}_{26} \mathrm{NO}_{2}{ }^{+}[\mathrm{M}+\mathrm{H}]^{+}$240.1958; found 240.1949. 


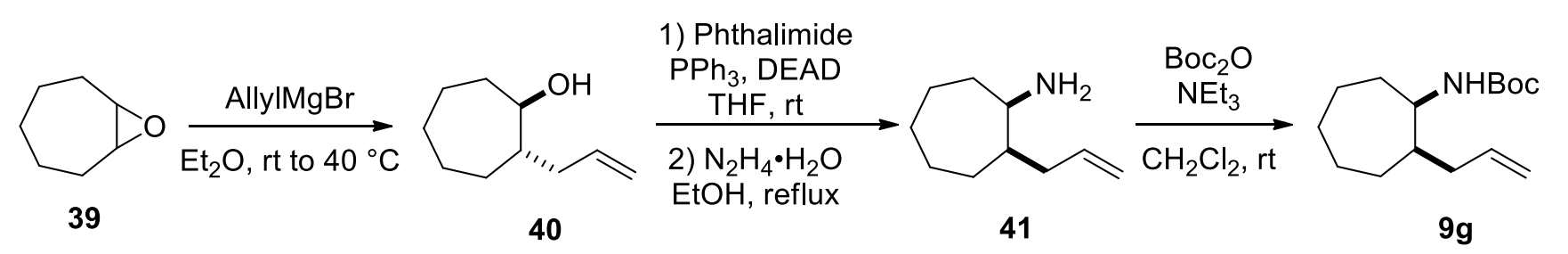

Following a reported procedure, ${ }^{17 \mathrm{a}}$ allyl magnesium bromide $\left(1.0 \mathrm{M}\right.$ in $\mathrm{Et}_{2} \mathrm{O}, 17.5 \mathrm{~mL}, 17.5$ mmol, 2.5 equiv) was diluted with $\mathrm{Et}_{2} \mathrm{O}(16.8 \mathrm{~mL})$. Cycloheptene oxide 39 (0.81 mL, $7.0 \mathrm{mmol}, 1.0$ equiv) was added dropwise to the resulting solution at $\mathrm{rt}$ over $15 \mathrm{~min}$. The mixture was refluxed for $2 \mathrm{~h}$. It was the cooled to $0{ }^{\circ} \mathrm{C}$ and then the reaction was quenched by addition of aqueous $\mathrm{NH}_{4} \mathrm{Cl}$ (saturated solution, $18 \mathrm{~mL})$. The two layers were separated and the aqueous one was extracted with $\mathrm{Et}_{2} \mathrm{O}(3 \times 25$ $\mathrm{mL})$. The combined organic layers were washed with water ( 3 × $25 \mathrm{~mL}$ ) and brine, dried over $\mathrm{MgSO}_{4}$, filtered and the solvent was removed in vacuo. Column chromatography $\left(\mathrm{SiO}_{2}, \mathrm{CH}_{2} \mathrm{Cl}_{2} / \mathrm{EtOAc}^{97 / 3}\right.$ to 93/7) afforded the pure 2-allyl cycloheptanol (40) as a colorless oil (978 mg, $6.34 \mathrm{mmol}, 91 \%$ yield), which was used directly in the next step.

Following a reported procedure, ${ }^{17 \mathrm{c}}$ phthalimide $(1.06 \mathrm{~g}, 7.20 \mathrm{mmol}, 1.3 \mathrm{equiv})$ and triphenyl phosphine (1.89 g, $7.20 \mathrm{mmol}, 1.3$ equiv) were dissolved in THF (38 mL). Secondary alcohol 40 (855 mg, 5.54 mmol, 1.0 equiv) was added; DEAD (40\% solution in toluene, $3.5 \mathrm{~mL}, 7.8 \mathrm{mmol}, 1.4$ equiv) was then added dropwise at $\mathrm{rt}$ over $20 \mathrm{~min}$. The reaction mixture was stirred at $\mathrm{rt}$ for $23 \mathrm{~h}$. The solvent was removed under reduced pressure and the resulting crude oil was triturated with PET/Et $2 \mathrm{O}(2: 1$ mixture) until complete precipitation of the solids. The latter were filtered off and washed with the same mixture of solvents. The organic layers were combined and the solvents were removed in vacuo. Purification by column chromatography ( $\mathrm{SiO}_{2}$, Pentane/EtOAc $95 / 5$ to $93 / 7$ ) afforded the corresponding phthalimide as a colorless solid (1.32 $\mathrm{g}, 4.66 \mathrm{mmol}, 84 \%$ yield), which was used directly for the next step. 
The phthalimide obtained in the previous step (1.09 g, $3.86 \mathrm{mmol}, 1.0$ equiv) was dissolved in EtOH (34 mL). Hydrazine hydrate $(0.47 \mathrm{~mL}, 9.6 \mathrm{mmol}, 2.5$ equiv) was added and the mixture was refluxed for $3 \mathrm{~h}$ (during this time a white solid precipitated). The mixture was allowed to cool down to $\mathrm{rt}$ and concentrated $\mathrm{HCl}(37 \%$ w/w, ca. $20 \mathrm{~mL})$ was added dropwise to quench the reaction. The solvent was removed by distillation under reduced pressure and the residual aqueous solution was washed with $\mathrm{Et}_{2} \mathrm{O}(2 \times 30 \mathrm{~mL})$ and treated with solid $\mathrm{NaOH}$ until $\mathrm{pH}$ 12. It was then extracted with $\mathrm{Et}_{2} \mathrm{O}(4 \times 100$ $\mathrm{mL}$ ). The combined organic layers were washed with brine and dried over $\mathrm{Na}_{2} \mathrm{SO}_{4}$, filtered and the solvent was removed in vacuo. Crude amine 41 was obtained as a pale yellow oil (468 mg, $3.05 \mathrm{mmol}$, $79 \%$ yield), which was used for the next step without further purification.

Crude secondary amine 41 (460 mg, $3.00 \mathrm{mmol}, 1.0$ equiv) was dissolved in $\mathrm{CH}_{2} \mathrm{Cl}_{2}(8.8 \mathrm{~mL})$. $\mathrm{Et}_{3} \mathrm{~N}$ (freshly distilled on $\mathrm{CaH}_{2}, 0.92 \mathrm{~mL}, 6.6 \mathrm{mmol}, 2.2$ equiv) was added and the solution was cooled to $0{ }^{\circ} \mathrm{C}$. Boc $2 \mathrm{O}(785 \mathrm{mg}, 3.60 \mathrm{mmol}, 1.4$ equiv) was added in two portions and the resulting mixture was stirred at rt overnight. In order to remove the excess of $\mathrm{Boc}_{2} \mathrm{O},{ }^{24}$ the solvent was then removed by evaporation under reduced pressure and the residue was dissolved in EtOH (12 mL). Imidazole (1.02 $\mathrm{g}, 15.0$ mmol, 5.0 equiv) was added and the mixture was stirred at $\mathrm{rt}$ for $15 \mathrm{~min}$. The mixture was then concentrated in vacuo and diluted with $\mathrm{CHCl}_{3}(30 \mathrm{~mL})$. The organic solution was then washed with aqueous $\mathrm{HCl}\left(1 \% \mathrm{v} / \mathrm{v}, 8.8 \mathrm{~mL}, 0{ }^{\circ} \mathrm{C}\right)$, dried over $\mathrm{MgSO}_{4}$, filtered and the solvent was removed in vacuo. Purification by column chromatography $\left(\mathrm{SiO}_{2}\right.$, pentane/EtOAc 95/5) afforded $\mathrm{N}$-Boc protected amine $\mathbf{9 g}$ as a colorless viscous oil (596 mg, $2.35 \mathrm{mmol}, 78 \%$ yield). $\mathrm{R}_{\mathrm{f}} 0.57$ (Hexane/EtOAc 5/1); ${ }^{1} \mathrm{H}$ NMR (400 $\left.\mathrm{MHz}, \mathrm{CDCl}_{3}\right) \delta 5.77(\mathrm{dddd}, 1 \mathrm{H}, J=17.1,10.0,7.2,7.2 \mathrm{~Hz}), 5.00(\mathrm{ddd}, 1 \mathrm{H}, J=14.4,3.3,1.5 \mathrm{~Hz}), 4.97$ (ddd, $1 \mathrm{H}, J=5.8,1.8,1.8 \mathrm{~Hz}), 4.51(\mathrm{~d}, 1 \mathrm{H}, J=7.9 \mathrm{~Hz}), 3.89(\mathrm{~m}, 1 \mathrm{H}), 2.12(\mathrm{~m}, 1 \mathrm{H}), 1.90(\mathrm{~m}, 1 \mathrm{H})$, $1.75(\mathrm{~m}, 1 \mathrm{H}), 1.65(\mathrm{~m}, 2 \mathrm{H}), 1.62-1.42(\mathrm{~m}, 6 \mathrm{H}), 1.42(\mathrm{~s}, 9 \mathrm{H}), 1.25(\mathrm{~m}, 2 \mathrm{H}) ;{ }^{13} \mathrm{C} \mathrm{NMR}(101 \mathrm{MHz}$, $\left.\mathrm{CDCl}_{3}\right) \delta 155.4,137.6,115.8,78.8,52.6,42.6,37.3,33.1,28.9,28.4,27.7,26.3,23.4$; IR $3455(\mathrm{w})$, 3344 (br w), 3075 (w), 2977 (w), 2926 (m), 2859 (w), 1696 (s), 1642 (w), 1500 (m), 1456 (w), 1389 
(m), 1366 (m), 1341 (w), 1319 (w), 1246 (m), 1169 (s), $1106(w), 1047(w), 1021(w), 998(w), 955$ (w),

$911(\mathrm{~m}), 889(\mathrm{w})$; HRMS (ESI) calcd for $\mathrm{C}_{15} \mathrm{H}_{28} \mathrm{NO}_{2}{ }^{+}[\mathrm{M}+\mathrm{H}]^{+}$254.2115; found 254.2117.

\section{tert-Butyl 2-allylphenylcarbamate (9h):}

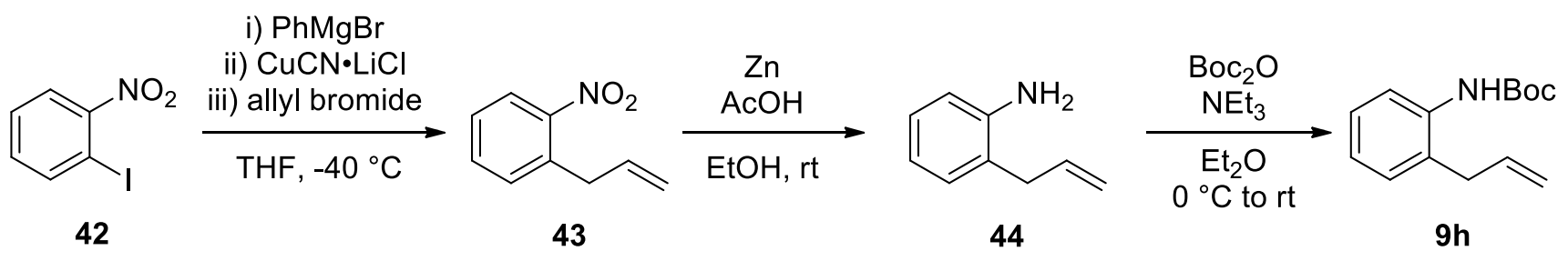

Following a reported procedure, ${ }^{17 \mathrm{~h}}$ 2-iodonitrobenzene (42) $(1.74 \mathrm{~g}, 7.00 \mathrm{mmol}, 1.0$ equiv) was dissolved in THF $(10 \mathrm{~mL})$ and the solution was cooled to $-40{ }^{\circ} \mathrm{C}$. Phenyl magnesium bromide $(1.0 \mathrm{M}$ in THF, $7.7 \mathrm{~mL}, 7.7 \mathrm{mmol}, 1.1$ equiv) was added dropwise and the resulting mixture was stirred at $-40{ }^{\circ} \mathrm{C}$ for $15 \mathrm{~min}$ before a solution of $\mathrm{CuCN}(627 \mathrm{mg}, 7.00 \mathrm{mmol}, 1.0$ equiv) and $\mathrm{LiCl}$ (593 $\mathrm{mg}, 14.0 \mathrm{mmol}$, 2.0 equiv) in THF (4.0 mL) was also added. The mixture was stirred for further 15 min and then allyl bromide $\left(0.67 \mathrm{~mL}, 7.7 \mathrm{mmol}, 1.1\right.$ equiv) was added. The mixture was stirred at $-40{ }^{\circ} \mathrm{C}$ for 2 hours and then allowed to warm to $\mathrm{rt}$ and quenched by the addition of aqueous $\mathrm{NH}_{4} \mathrm{Cl}$ (saturated solution, ca. 10 $\mathrm{mL})$. The aqueous layer was extracted with $\mathrm{Et}_{2} \mathrm{O}(3 \times 20 \mathrm{~mL})$ and the combined organic extracts were treated with activated charcoal. After the latter was filtered off, the organic solution was dried over over $\mathrm{MgSO}_{4}$, filtered and the solvent removed by evaporation under reduced pressure. Purification by column chromatography $\left(\mathrm{SiO}_{2}\right.$, Pentane/ $\mathrm{CH}_{2} \mathrm{Cl}_{2} 100 / 0$ to $\left.95 / 5\right)$ afforded 2-allyl nitrobenzene (43) as a pale yellow oil (590 mg, $3.60 \mathrm{mmol}, 52 \%$ yield). ${ }^{1} \mathrm{H}$ NMR (400 MHz, $\left.\mathrm{CDCl}_{3}\right) \delta 7.91(\mathrm{dd}, 1 \mathrm{H}, J=8.6,1.4$ Hz), 7.55 (d, 1H, J = 7.6, 1.2, Hz), 7.41-7.32 (m, $2 \mathrm{H}), 5.97$ (dddd, $1 \mathrm{H}, J=16.7,10.1,6.5,6.5 \mathrm{~Hz}), 5.12$ $(\mathrm{m}, 1 \mathrm{H}), 5.08(\mathrm{~m}, 1 \mathrm{H}), 3.69(\mathrm{~d}, 2 \mathrm{H}, J=6.5 \mathrm{~Hz})$.

Following a reported procedure, ${ }^{17 \mathrm{i}} \mathrm{Zn}$ (dust, $3.53 \mathrm{~g}, 54.0 \mathrm{mmol}, 15.0$ equiv) and acetic acid (3.1 $\mathrm{mL}, 54 \mathrm{mmol}, 15$ equiv) were added to a solution of 2-allyl nitrobenzene (43) $(590 \mathrm{mg}, 3.60 \mathrm{mmol}, 1.0$ equiv) in $\mathrm{EtOH}(36 \mathrm{~mL})$. The resulting suspension was stirred at $\mathrm{rt}$ for 1.5 hours and then filtered through celite. After washing the celite pad with EtOH, the organic solution was concentrated in vacuo. 
Aqueous $\mathrm{NaHCO}_{3}$ (saturated solution, $30 \mathrm{~mL}$ ) was added to the residue and the aqueous layer was extracted with EtOAc $(3 \times 30 \mathrm{~mL})$. The combined organic extracts were washed with brine, dried over $\mathrm{MgSO}_{4}$, filtered and the solvent was removed in vacuo. The obtained crude oil was used for the next step without further purification.

Crude 2-allyl aniline (44) (ca. $480 \mathrm{mg}$, ca. $3.60 \mathrm{mmol}, 1.0$ equiv) was dissolved in $\mathrm{Et}_{2} \mathrm{O}(5.8 \mathrm{~mL})$ and $\mathrm{Et}_{3} \mathrm{~N}$ (1.1 mL, $7.9 \mathrm{mmol}, 2.2$ equiv) was added to the resulting solution, cooled to $0{ }^{\circ} \mathrm{C}$. A solution of $\mathrm{Boc}_{2} \mathrm{O}$ (1.65 g, $7.54 \mathrm{mmol}, 2.1$ equiv) in $\mathrm{Et}_{2} \mathrm{O}(5.8 \mathrm{~mL})$ was then added and the mixture was stirred at $0{ }^{\circ} \mathrm{C}$ for 10 minutes and then at $\mathrm{rt}$ for 20 hours. After filtering the solids off, the resulting solution was concentrated in vасио. Purification of the crude oil by column chromatography $\left(\mathrm{SiO}_{2}\right.$, pentane/EtOAc 95/5) afforded the pure N-Boc protected 2-allyl aniline $\mathbf{9 h}$ as a colorless oil (365 mg, $1.56 \mathrm{mmol}, 43 \%$ yield). $\mathrm{R}_{\mathrm{f}} 0.57$ (Hexane/EtOAc 5/1); ${ }^{1} \mathrm{H} \mathrm{NMR}\left(400 \mathrm{MHz}, \mathrm{CDCl}_{3}\right) \delta 7.78(\mathrm{~d}, 1 \mathrm{H}, J=7.9 \mathrm{~Hz}), 7.24(\mathrm{~m}, 2$ H), 7.14 (dd, $1 \mathrm{H}, J=7.6,1.3 \mathrm{~Hz}), 7.04$ (td, $1 \mathrm{H}, J=7.4,1.0 \mathrm{~Hz}), 6.43$ (br s, $1 \mathrm{H}), 5.96$ (dddd, $1 \mathrm{H}, J=$ 17.2, 9.9, 5.8, $5.8 \mathrm{~Hz}), 5.16(\mathrm{dq}, 1 \mathrm{H}, J=9.9,1.5 \mathrm{~Hz}), 5.06(\mathrm{dq}, 1 \mathrm{H}, J=17.2,1.7 \mathrm{~Hz}), 3.37(\mathrm{~d}, 2 \mathrm{H}, J=$ $6.0 \mathrm{~Hz}), 1.51(\mathrm{~s}, 9 \mathrm{H}) ;{ }^{13} \mathrm{C} \mathrm{NMR}\left(101 \mathrm{MHz}, \mathrm{CDCl}_{3}\right) \delta 153.1,136.4,135.8,129.9,128.9,127.3,123.9$, 121.9, 116.5, 80.2, 36.4, 28.3. IR 3430 (br w), 3335 (br w), 3003 (w), 2976 (w), 2932 (w), 2877 (w), $2876(w), 2871(w), 2360(w), 2342(w), 2332(w), 1731(\mathrm{~m}), 1688(\mathrm{~m}), 1639(w), 1613(w), 1589(w)$, $1513(\mathrm{~s}), 1477$ (w), $1452(\mathrm{~m}), 1429(\mathrm{w}), 1412(\mathrm{~m}), 1392(\mathrm{w}), 1366(\mathrm{~m}), 1300(\mathrm{w}), 1299(\mathrm{w}), 1245$ (m), $1158(\mathrm{~s}), 1119(\mathrm{~m}), 1037(\mathrm{w}), 1028(\mathrm{w}), 999(\mathrm{w}), 919(\mathrm{w}), 878(\mathrm{w}), 843(\mathrm{w}), 816(\mathrm{w})$. The data for the characterization of compound $\mathbf{9 h}$ correspond to the ones reported in the literature. ${ }^{23}$

\section{N-(Pent-4-en-1-yl)aniline (9i)}

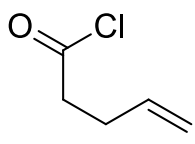

45

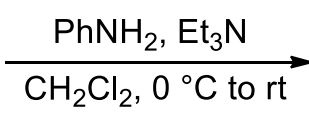

Aniline (0.36 mL, $4.0 \mathrm{mmol}, 1.0$ equiv) was dissolved in $\mathrm{CH}_{2} \mathrm{Cl}_{2}(12 \mathrm{~mL})$ and the resulting solution was cooled to $0{ }^{\circ} \mathrm{C}$. $\mathrm{Et}_{3} \mathrm{~N}(0.83 \mathrm{~mL}, 6.0 \mathrm{mmol}, 1.5$ equiv) was added. Pentenoyl chloride (45) (0.44 
$\mathrm{mL} ; 4.0 \mathrm{mmol}, 1.0$ equiv) was then added dropwise and the mixture was allowed to warm to rt overnight. It was then diluted with $\mathrm{CH}_{2} \mathrm{Cl}_{2}(10 \mathrm{~mL})$ and washed with aqueous $\mathrm{HCl}(1.0 \mathrm{M}, 20 \mathrm{~mL})$, aqueous $\mathrm{NaOH}(1.0 \mathrm{M}, 20 \mathrm{~mL})$, water and brine, dried over $\mathrm{MgSO}_{4}$, filtered and the solvent was removed in vacuo. The resulting off-white solid $(690 \mathrm{mg}, 3.94 \mathrm{mmol}, 98 \%$ yield) was used in the next step without further purification.

Pentenamide 46 (683 mg, $3.90 \mathrm{mmol}, 1.0$ equiv) was dissolved in THF (4.3 mL) and the solution was cooled to $0{ }^{\circ} \mathrm{C}$. A suspension of $\mathrm{LiAlH}_{4}\left(430 \mathrm{mg}, 11.3 \mathrm{mmol}, 2.9\right.$ equiv) in $\mathrm{Et}_{2} \mathrm{O}(11.3 \mathrm{~mL})$ was added dropwise. The resulting mixture was allowed to warm to $\mathrm{rt}$ and stirred overnight. It was then cooled back to $0{ }^{\circ} \mathrm{C}$ and water $(0.43 \mathrm{~mL})$, aqueous $\mathrm{NaOH}(10 \% \mathrm{w} / \mathrm{w}, 0.86 \mathrm{~mL})$ and again water $(1.3$ $\mathrm{mL}$ ) were added under vigorous stirring in order to induce the complete precipitation of lithium salts. The solids were filtered off and washed with $\mathrm{Et}_{2} \mathrm{O}$ several times. The organic solution was concentrated in vacuo to afford $\mathrm{N}$-(pent-4-en-1-yl)aniline (9i) $(585 \mathrm{mg}, 3.63 \mathrm{mmol}, 93 \%$ yield) as a colorless oil, which did not require further purification. $\mathrm{R}_{\mathrm{f}} 0.43$ (Hexane/EtOAc 10/1); ${ }^{1} \mathrm{H}$ NMR $\left(400 \mathrm{MHz}, \mathrm{CDCl}_{3}\right) \delta$ $7.22(\mathrm{~m}, 2 \mathrm{H}), 6.74(\mathrm{t}, 1 \mathrm{H}, J=7.2 \mathrm{~Hz}), 6.64(\mathrm{~m}, 2 \mathrm{H}), 5.89$ (dddd, $1 \mathrm{H}, J=16.9,10.2,6.7,6.7 \mathrm{~Hz}), 5.11$ (ddd, $1 \mathrm{H}, J=17.1,3.3,1.7 \mathrm{~Hz}), 5.05$ (ddd, $1 \mathrm{H}, J=10.5,3.5,1.5 \mathrm{~Hz}$ ), 3.65 (br s, $1 \mathrm{H}), 3.17$ (dd, $2 \mathrm{H}, J$ $=7.0,7.0 \mathrm{~Hz}), 2.22(\mathrm{~m}, 2 \mathrm{H}), 1.76$ (quint, $2 \mathrm{H}, J=7.3 \mathrm{~Hz}) ;{ }^{13} \mathrm{C} \mathrm{NMR}\left(101 \mathrm{MHz}, \mathrm{CDCl}_{3}\right) \delta 148.3,138.0$, 129.2, 117.1, 115.0, 112.6, 43.3, 31.3, 28.6; IR 3411 (br w), 3077 (w), 3054 (w), 3053 (w), 3021 (w), $3001(w), 2976(w), 2930(w), 2858(w), 1641(w), 1603(s), 1507(s), 1477(w), 1433(w), 1371(w)$, $1320(\mathrm{~m}), 1279(\mathrm{w}), 1259(\mathrm{~m}), 1180(\mathrm{w}), 1153(\mathrm{w}), 1102(\mathrm{w}), 993(\mathrm{~m}), 912(\mathrm{~m}), 869(\mathrm{w}), 837(\mathrm{w})$. The values for the characterization of $9 \mathbf{i}$ correspond to the ones reported in literature. ${ }^{6 f}$

\section{4-Methoxy- $N$-(pent-4-en-1-yl)aniline (9j)}

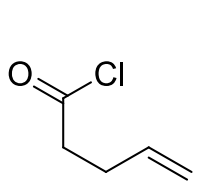

45

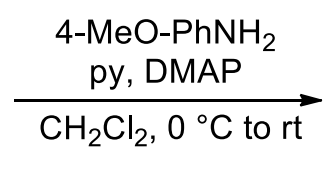

$\underset{\mathrm{CH}_{2} \mathrm{Cl}_{2}, \mathrm{O}^{\circ} \mathrm{C} \text { to } \mathrm{rt}}{\longrightarrow}$

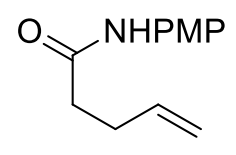

47

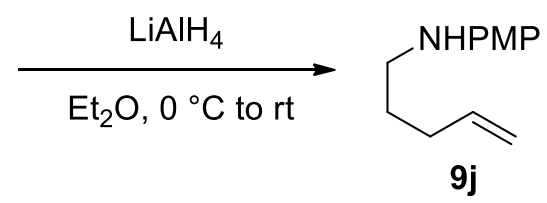


Following a reported procedure, ${ }^{17 \mathrm{~b}}$ pyridine $(0.22 \mathrm{~mL}, 2.8 \mathrm{mmol}, 1.1$ equiv) and DMAP (16.0 $\mathrm{mg}, 0.125 \mathrm{mmol}, 0.050$ equiv) were added to a solution of para-anisidine (308 $\mathrm{mg}, 2.50 \mathrm{mmol}, 1.0$ equiv) in $\mathrm{CH}_{2} \mathrm{Cl}_{2}$ (7.0 mL). The mixture was cooled to $0{ }^{\circ} \mathrm{C}$ and pentenoyl chloride (45) $(0.30 \mathrm{~mL}, 2.8$ mmol, 1.1 equiv) was added dropwise. The mixture was allowed to warm to rt. The reaction was then quenched by adding aqueous $\mathrm{HCl}(10 \% \mathrm{v} / \mathrm{v}, 7.0 \mathrm{~mL})$ and the aqueous layer was separated and extracted with $\mathrm{CH}_{2} \mathrm{Cl}_{2}(3 \times 10 \mathrm{~mL})$. The combined organic extracts were washed with aqueous $\mathrm{NaHCO}_{3}$ (saturated solution, $10 \mathrm{~mL}$ ), water and brine, dried over $\mathrm{MgSO}_{4}$, filtered and the solvent was removed in vacuo. Purification by column chromatography $\left(\mathrm{SiO}_{2}, \mathrm{CH}_{2} \mathrm{Cl}_{2} / \mathrm{MeOH} 99 / 1\right.$ to $\left.95 / 5\right)$ afforded pentenamide 47 as an off-white solid (400 mg, $1.95 \mathrm{mmol}, 78 \%$ yield).

Pentenamide 47 (400 mg, $1.95 \mathrm{mmol}, 1.0$ equiv) was dissolved in a mixture of THF (1.4 mL) and $\mathrm{Et}_{2} \mathrm{O}(6.1 \mathrm{~mL})$ and the solution was cooled to $0{ }^{\circ} \mathrm{C}$. A suspension of $\mathrm{LiAlH}_{4}(185 \mathrm{mg}, 4.87 \mathrm{mmol}$, 2.5 equiv) in $\mathrm{Et}_{2} \mathrm{O}(4.9 \mathrm{~mL})$ was added dropwise. The resulting mixture was allowed to warm to $\mathrm{rt}$ and stirred overnight. It was then cooled back to $0{ }^{\circ} \mathrm{C}$ and water $(0.20 \mathrm{~mL})$, aqueous $\mathrm{NaOH}(10 \%$ w/w, 0.40 $\mathrm{mL})$ and again water $(0.6 \mathrm{~mL})$ were added under vigorous stirring in order to induce the complete precipitation of lithium salts. The solids were filtered off and washed with $\mathrm{Et}_{2} \mathrm{O}$ several times. The organic solution was concentrated in vacuo to afford 4-methoxy-N-(pent-4-en-1-yl)aniline (9j) (356 mg, 1.86 mmol, 95\% yield) as a brown oil, which did not require further purification. $\mathrm{R}_{\mathrm{f}} 0.55$ (Hexane/EtOAc 5/1); ${ }^{1} \mathrm{H}$ NMR (400 MHz, $\left.\mathrm{CDCl}_{3}\right) \delta 6.78(\mathrm{~d}, 2 \mathrm{H}, J=8.6 \mathrm{~Hz}), 6.58(\mathrm{~d}, 2 \mathrm{H}, J=8.6 \mathrm{~Hz}), 5.84(\mathrm{ddd}, 1 \mathrm{H}$, $J=17.0,10.1,6.7 \mathrm{~Hz}), 5.06(\mathrm{~d}, 1 \mathrm{H}, J=17.2 \mathrm{~Hz}), 5.00(\mathrm{~d}, 1 \mathrm{H}, J=10.1 \mathrm{~Hz}), 3.75(\mathrm{~s}, 3 \mathrm{H}), 3.35$ (br s, 1 $\mathrm{H}), 3.10(\mathrm{t}, 2 \mathrm{H}, J=7.0 \mathrm{~Hz}), 2.17(\mathrm{dd}, 2 \mathrm{H}, J=13.7,6.7 \mathrm{~Hz}), 1.71$ (quint, $2 \mathrm{H}, J=7.1 \mathrm{~Hz})$; ${ }^{13} \mathrm{C} \mathrm{NMR}$ $\left(101 \mathrm{MHz} \mathrm{CDCl}_{3}\right) \delta 151.9,142.6,138.0,114.9,114.8,114.0,55.7,44.3,31.3,28.7 ; \mathrm{IR} 3411(\mathrm{w}), 3077$ (w), $3054(\mathrm{w}), 3021(\mathrm{w}), 3001(\mathrm{w}), 2976(\mathrm{w}), 2930(\mathrm{w}), 2858(\mathrm{w}), 1641(\mathrm{w}), 1603(\mathrm{~s}), 1507(\mathrm{~s}), 1477$ (w), $1433(w), 1371(w), 1320(\mathrm{~m}), 1279(w), 1259(\mathrm{~m}), 1180(\mathrm{w}), 1153(\mathrm{w}), 1153(\mathrm{w}), 1102(\mathrm{w}), 1102$ (w), $1023(w), 993(\mathrm{~m}), 912(\mathrm{~m}), 869(\mathrm{w}), 869(\mathrm{w})$. The values for the characterization of $\mathbf{9 j}$ correspond to the ones reported in literature. ${ }^{6 f}$ 


\section{General procedure for the bromination of terminal alkynes: ${ }^{15 a}$}

The terminal alkyne (1.0 equiv) is dissolved in acetone (ca. $6.8 \mathrm{~mL}$ per mmol of alkyne). Nbromosuccinimide (1.2 equiv) and $\mathrm{AgNO}_{3}$ (0.1 equiv) are added to the resulting solution in this order and the mixture is stirred at $\mathrm{rt}$ for 3-6 hours, until complete consumption of the starting material according to TLC. It was then poured onto iced water. The aqueous layer was extracted with pentane (3 times) and the combined organic extracts were dried over $\mathrm{MgSO}_{4}$, filtered and the solvent removed by evaporation under reduced pressure. The bromo alkyne was isolated by column chromatography in 95-99\% purity as judged by ${ }^{1} \mathrm{H}$ NMR.

\section{2-Bromo-1-triisopropylsilyl acetylene (4)}

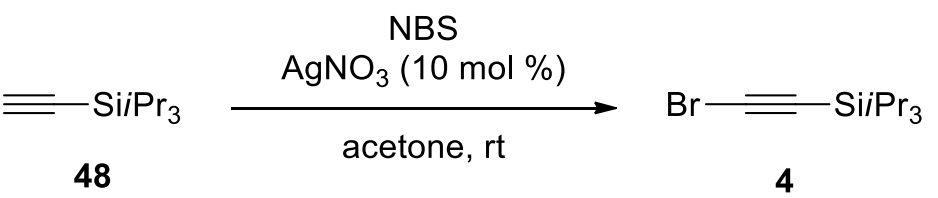

Triisopropylsilylacetylene (48) (813 mg, $4.45 \mathrm{mmol}, 1.00$ equiv) was brominated according to the general procedure. Bromoalkyne 4 was obtained as a colorless oil (1.16 g, 4.43 mmol, 99\%) without further purification. ${ }^{1} \mathrm{H}$ NMR $\left(400 \mathrm{MHz}, \mathrm{CDCl}_{3}\right) \delta 1.20-0.97(\mathrm{~m}, 21 \mathrm{H}) ;{ }^{13} \mathrm{C} \mathrm{NMR}\left(101 \mathrm{MHz}, \mathrm{CDCl}_{3}\right) \delta$ $83.5,61.7,18.5,11.3$. The values for the characterization of 4 correspond to the ones reported in literature. $^{28}$

\section{1-Bromooct-1-yne (6a)}

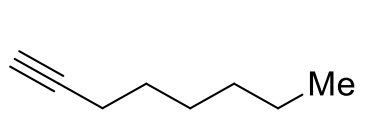

19

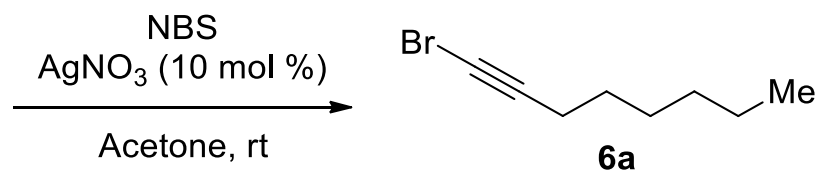

$6 a$

1-Octyne (19) $(3.0 \mathrm{~mL}, 20 \mathrm{mmol}, 1.0$ equiv.) was brominated according to the general procedure. After purification by column chromatography $\left(\mathrm{SiO}_{2}\right.$, pentane), bromoalkyne $\mathbf{6 a}$ was obtained as a colorless oil (3.33 g, $17.6 \mathrm{mmol}, 88 \%$ yield). $\mathrm{R}_{\mathrm{f}} 0.91$ (Hexane); ${ }^{1} \mathrm{H}$ NMR (400 MHz, $\left.\mathrm{CDCl}_{3}\right) \delta 2.20$ (t, $2 \mathrm{H}, J=7.0$ $\mathrm{Hz}$ ), 1.51 (quint, $2 \mathrm{H}, J=6.4 \mathrm{~Hz}$ ), 1.42-1.33 (quint, $2 \mathrm{H}, J=7.1 \mathrm{~Hz}$ ), 1.33-1.22 (m, $4 \mathrm{H}) 0.89(\mathrm{t}, 3 \mathrm{H}, J$ 
$=6.7 \mathrm{~Hz}) ;{ }^{13} \mathrm{C} \mathrm{NMR}\left(101 \mathrm{MHz}, \mathrm{CDCl}_{3}\right) \delta 80.5,37.4,31.3,28.5,28.3,22.5,19.7,14.0$. The values for the characterization of $\mathbf{6 a}$ correspond to the ones reported in literature. ${ }^{29}$

\section{1-Chlorooct-1-yne (6b)}

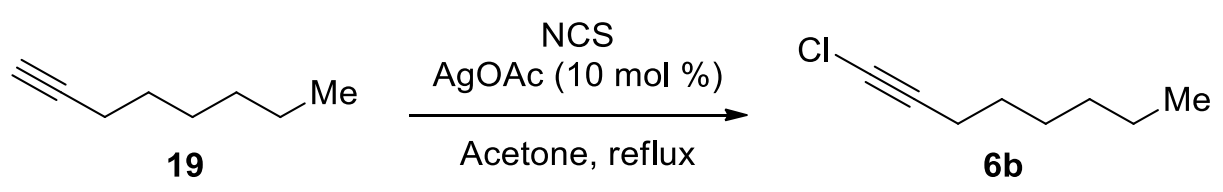

Following a slightly modified version of a reported procedure, ${ }^{15 \mathrm{~g}} \mathrm{~N}$-Chlorosuccinimide $(641 \mathrm{mg}$, $4.80 \mathrm{mmol}, 1.20$ equiv) and AgOAc (67.0 mg, $0.400 \mathrm{mmol}, 0.10$ equiv) were added in this order to a solution of 1-octyne (19) $(0.60 \mathrm{~mL} ; 4.0 \mathrm{mmol}, 1.0$ equiv) in acetone $(16.0 \mathrm{~mL})$ and the solution was heated to reflux overnight. The mixture was poured onto ice and the resulting aqueous layer was extracted with pentane $(3 \times 20 \mathrm{~mL})$. The combined organic layers were washed with brine, dried over $\mathrm{MgSO}_{4}$, filtered and the solvent was removed in vacuo. Purification by column chromatography $\left(\mathrm{SiO}_{2}\right.$, Pentane) afforded chloro alkyne $6 \mathbf{b}$ as a smelly colorless oil (577 $\mathrm{mg}, 3.99 \mathrm{mmol}$, quantitative). ${ }^{1} \mathrm{H}$ NMR (400 MHz, $\left.\mathrm{CDCl}_{3}\right) \delta 2.16(\mathrm{t}, 2 \mathrm{H}, J=7.0 \mathrm{~Hz}$ ), 1.50 (quint, $J=6.9 \mathrm{~Hz}, 2 \mathrm{H}), 1.43-1.24(\mathrm{~m}, 6 \mathrm{H}$ ), $0.89(\mathrm{t}, 3 \mathrm{H}, J=6.7 \mathrm{~Hz}) ;{ }^{13} \mathrm{C} \mathrm{NMR}\left(101 \mathrm{MHz} \mathrm{CDCl}_{3}\right) \delta 69.7,56.9,31.3,28.5,28.4,22.5,18.8,14.0$. The values for the characterization of $\mathbf{6 b}$ correspond to the ones reported in literature. ${ }^{30}$

\section{1-Iodooct-1-yne (6c)}

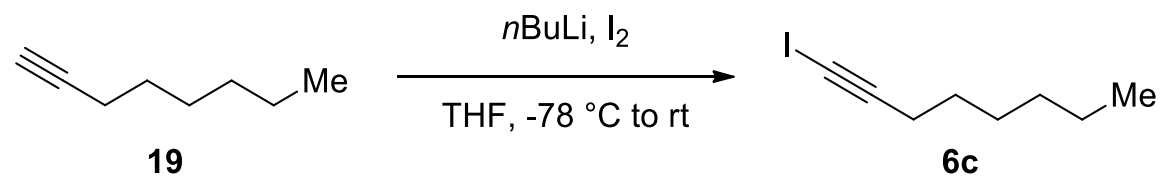

Following a reported procedure, ${ }^{15 \mathrm{~b}}$ a solution of 1 -octyne $(\mathbf{1 9})(0.60 \mathrm{~mL}, 4.0 \mathrm{mmol}, 1.00$ equiv $)$ in $\mathrm{THF}(6.5 \mathrm{~mL})$ was cooled to $-78^{\circ} \mathrm{C}$ and $n \mathrm{BuLi}(2.5 \mathrm{M}$ in hexanes, $1.7 \mathrm{~mL}, 4.2 \mathrm{mmol}, 1.0$ equiv) was added dropwise. The solution was stirred at $-78{ }^{\circ} \mathrm{C}$ for $15 \mathrm{~min}$ and then at $0{ }^{\circ} \mathrm{C}$ for 5 min; it was then cooled back to $-78^{\circ} \mathrm{C}$ and a solution of iodine $(1.12 \mathrm{~g}, 4.40 \mathrm{mmol}, 1.10$ equiv) in THF (6.5 mL) was added dropwise. The mixture was stirred at $\mathrm{rt}$ for 2 hours and then diluted with $\mathrm{Et}_{2} \mathrm{O}$ and quenched with 
brine (ca. $15 \mathrm{~mL}$ ). The organic layer was separated, washed with aqueous $\mathrm{Na}_{2} \mathrm{~S}_{2} \mathrm{O}_{3}$ (saturated solution, $15 \mathrm{~mL}$ ), dried over $\mathrm{MgSO}_{4}$, filtered and the solvent was removed in vacuo. Purification by column chromatography $\left(\mathrm{SiO}_{2}\right.$, Pentane/Et $\left.2 \mathrm{O} 98 / 2\right)$ afforded iodo alkyne 6c as a smelly colorless oil (932 mg, $3.95 \mathrm{mmol}, 99 \%) .{ }^{1} \mathrm{H} \mathrm{NMR}\left(400 \mathrm{MHz}, \mathrm{CDCl}_{3}\right) \delta 2.35$ (t, $2 \mathrm{H}, J=7.0 \mathrm{~Hz}$ ), 1.50 (quint, $J=7.0 \mathrm{~Hz}, 2 \mathrm{H}$ ), 1.41-1.31 (m, $2 \mathrm{H}), 1.33-1.23(\mathrm{~m}, 4 \mathrm{H}), 0.89(\mathrm{t}, 3 \mathrm{H}, J=6.8 \mathrm{~Hz}) ;{ }^{13} \mathrm{C} \mathrm{NMR}\left(101 \mathrm{MHz}, \mathrm{CDCl}_{3}\right) \delta 94.8$, $65.8,31.3,28.4,22.5,20.8,14.0,-7.6$. The values for the characterization of $\mathbf{6 c}$ correspond to the ones reported in literature. ${ }^{29}$

((5-Bromopent-4-yn-1-yl)oxy)(tert-butyl)diphenylsilane (6d)

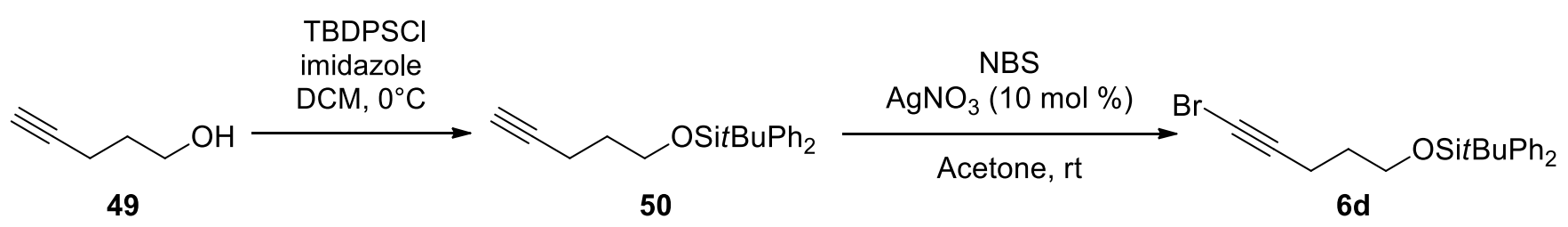

4-Pentyn-1-ol (49) (0.46 mL, $5.0 \mathrm{mmol})$ was dissolved in $\mathrm{CH}_{2} \mathrm{Cl}_{2}(10 \mathrm{~mL})$ and the solution was cooled to $0{ }^{\circ} \mathrm{C}$. After the addition of imidazole (442 mg, $6.50 \mathrm{mmol}, 1.3$ equiv), tert-butyl diphenyl silyl chloride (1.4 mL. 5.4 mmol, 1.1 equiv) was also added, dropwise. The mixture was stirred and allowed to warm to $\mathrm{rt}$ overnight. The reaction was then quenched by the addition of water (ca. $10 \mathrm{~mL}$ ). The aqueous layer was separated and extracted with $\mathrm{CH}_{2} \mathrm{Cl}_{2}(3 \times 10 \mathrm{~mL})$. The combined organic extracts were dried over $\mathrm{MgSO}_{4}$, filtered and the solvent was removed in vacuo. Purification by column chromatography $\left(\mathrm{SiO}_{2}\right.$, Pentane/EtOAc 98/2) afforded the O-silylated pentynol $\mathbf{5 0}$ as a colorless oil (1.33 g, $4.12 \mathrm{mmol}, 82 \%$ yield). ${ }^{1} \mathrm{H} \mathrm{NMR}\left(400 \mathrm{MHz}, \mathrm{CDCl}_{3}\right) \delta 7.67(\mathrm{~m}, 4 \mathrm{H}), 7.46-7.34(\mathrm{~m}, 6 \mathrm{H}), 3.75(\mathrm{t}, 2 \mathrm{H}, J$ $=6.0 \mathrm{~Hz}), 2.35(\mathrm{td}, 2 \mathrm{H}, J=7.2,2.6 \mathrm{~Hz}), 1.92(\mathrm{t}, 1 \mathrm{H}, J=2.6 \mathrm{~Hz}), 1.78(\mathrm{ddd}, 2 \mathrm{H}, J=13.1,7.1,6.0 \mathrm{~Hz})$, $1.05(\mathrm{~s}, 9 \mathrm{H})$.

O-Silylated alcohol $\mathbf{5 0}(1.33 \mathrm{~g} .4 .12 \mathrm{mmol})$ was brominated according to the general procedure. After purification by column chromatography $\left(\mathrm{SiO}_{2}\right.$, Pentane/EtOAc $\left.98 / 2\right)$, bromoalkyne 6d was obtained as a pale yellow oil (1.42 g, $3.54 \mathrm{mmol}, 86 \%$ yield). ${ }^{1} \mathrm{H} \mathrm{NMR}\left(400 \mathrm{MHz}, \mathrm{CDCl}_{3}\right) \delta 7.68(\mathrm{~m}, 4 \mathrm{H})$, 
7.47-7.34 (m, $6 \mathrm{H}), 3.74(\mathrm{t}, 2 \mathrm{H}, J=5.9 \mathrm{~Hz}), 2.38(\mathrm{t}, 2 \mathrm{H}, J=7.1 \mathrm{~Hz}), 1.76(\mathrm{ddd}, 2 \mathrm{H}, J=12.9,6.7,5.8$

$\mathrm{Hz}), 1.06(\mathrm{~s}, 9 \mathrm{H}) ;{ }^{13} \mathrm{C} \mathrm{NMR}\left(101 \mathrm{MHz}, \mathrm{CDCl}_{3}\right) \delta 135.5,133.7,129.6,127.6,79.9,62.1,37.8,31.1$, 26.8, 19.2, 16.2; IR $3070(w), 3050(w), 2954(w), 2932(w), 2931(w), 2893(w), 2857(w), 1590(w)$, $1470(w), 1428$ (w), $1389(w), 1361(w), 1189(w), 1107$ (s), 1063 (m), $1003(w), 961(w), 909(w), 823$ (w); HRMS (ESI) calcd for $\mathrm{C}_{21}{ }^{79} \mathrm{BrH}_{26} \mathrm{OSi}^{+}[\mathrm{M}+\mathrm{H}]^{+} 401.0931$; found 401.0943 .

\section{(5-Bromopent-4-yn-1-yl)benzene (6e)}

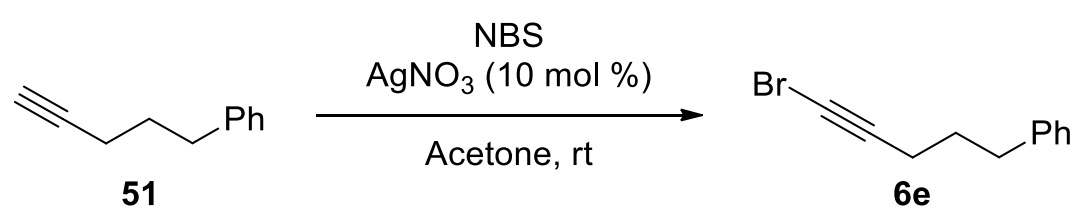

Pent-4-yn-1-ylbenzene (51) $(0.76 \mathrm{~mL}, 5.0 \mathrm{mmol}, 1.0$ equiv.) was brominated according to the general procedure. After purification by column chromatography $\left(\mathrm{SiO}_{2}\right.$, pentane), bromo alkyne 6e was obtained as a pale yellow oil (1.05 g, $4.71 \mathrm{mmol}, 94 \%$ yield). $\mathrm{R}_{\mathrm{f}} 0.38$ (Hexane); ${ }^{1} \mathrm{H} \mathrm{NMR}(400 \mathrm{MHz}$, $\left.\mathrm{CDCl}_{3}\right) \delta$ 7.33-7.28 (m, $\left.2 \mathrm{H}\right), 7.24-7.19(\mathrm{~m}, 3 \mathrm{H}), 2.73(\mathrm{t}, 2 \mathrm{H}, J=7.5 \mathrm{~Hz}), 2.24(\mathrm{t}, 2 \mathrm{H}, J=7.0 \mathrm{~Hz})$, $1.86(\mathrm{~m}, 2 \mathrm{H},) ;{ }^{13} \mathrm{C} \mathrm{NMR}\left(101 \mathrm{MHz}, \mathrm{CDCl}_{3}\right) \delta 141.3,128.5,128.3,125.9,79.9,38.1,34.7,29.8,19.1$. The values for the characterization of $\mathbf{6 e}$ correspond to the ones reported in literature. ${ }^{29}$

\section{1-Bromo-5-chloropent-1-yne (6f)}

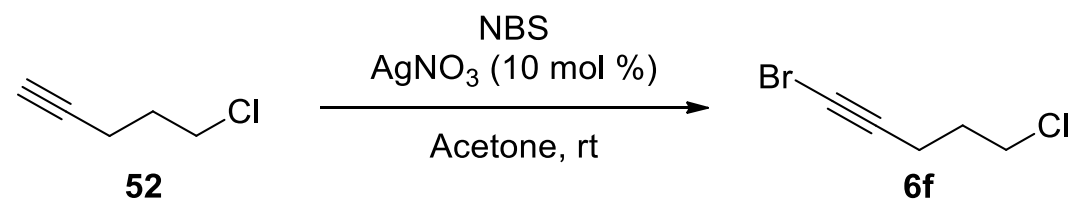

5-Chloropent-1-yne (52) (0.53 mL, $5.0 \mathrm{mmol}, 1.0$ equiv.) was brominated according to the general procedure. After purification by column chromatography $\left(\mathrm{SiO}_{2}\right.$, Pentane), bromoalkyne $\mathbf{6}$ f was obtained as a colorless oil ( $805 \mathrm{mg}, 4.44 \mathrm{mmol}, 89 \%$ yield).

$\mathrm{R}_{\mathrm{f}} 0.38$ (Hexane); ${ }^{1} \mathrm{H} \mathrm{NMR}\left(400 \mathrm{MHz}, \mathrm{CDCl}_{3}\right) \delta 3.64(\mathrm{t}, 2 \mathrm{H}, J=6.3 \mathrm{~Hz}), 2.41(\mathrm{t}, 2 \mathrm{H}, J=6.8 \mathrm{~Hz}), 1.97$ (quint, $2 \mathrm{H}, J=6.5 \mathrm{~Hz}) ;{ }^{13} \mathrm{C} \mathrm{NMR}\left(101 \mathrm{MHz}, \mathrm{CDCl}_{3}\right) \delta$ 78.4, 43.4, 39.0, 31.0, 17.1; IR $3000(\mathrm{w}), 2961$ 
(m), $2915(w), 2914(w), 2873(w), 2844(w), 2843(w), 2219(w), 2218(w), 1455(w), 1442(s), 1433$

(s), 1354 (w), 1329 (w), 1309 (m), 1290 (s), $1111(w), 1041(w), 1040(w), 1034(w), 1033$ (w), 991

(w), 990 (w), 972 (w), 945 (w), 911 (w), 854 (m); Anal. Calcd. for $\mathrm{C}_{5} \mathrm{H}_{6} \mathrm{ClBr}$ : C, 33.09\%; H, 3.33\%.

Found: C, 33.13\%; H, 3.06\%.

\section{(7-bromohepta-1,6-diyn-1-yl)triisopropylsilane (6g):}

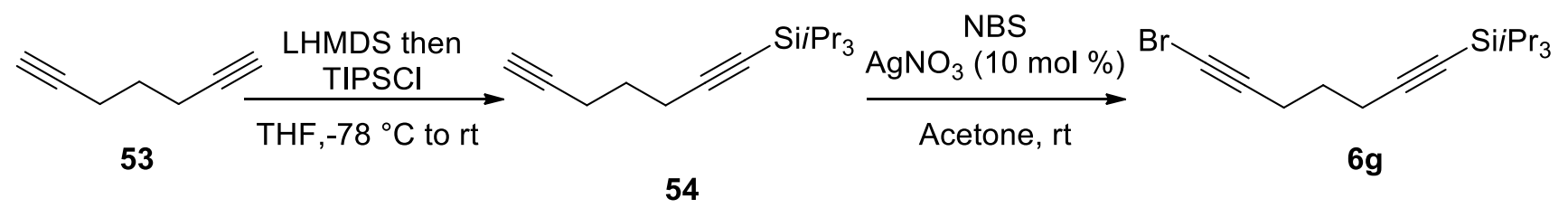

Following a reported procedure, ${ }^{15 \mathrm{e}}$ 1,6-heptadiyne $(\mathbf{5 3})(0.62 \mathrm{~mL}, 5.4 \mathrm{mmol}, 1.0$ equiv) was dissolved in THF $(8.0 \mathrm{~mL})$ and the solution was cooled to $-78{ }^{\circ} \mathrm{C}$. A $1.0 \mathrm{M}$ solution of LHMDS in THF (freshly prepared by treating HMDS $(5.3 \mathrm{mmol})$ with $n \mathrm{BuLi}(2.5 \mathrm{M}$ in hexanes, $2.1 \mathrm{~mL}, 5.3 \mathrm{mmol}, 0.98$ equiv) was added dropwise over $15 \mathrm{~min}$ and the resulting mixture was stirred at $-78{ }^{\circ} \mathrm{C}$ for $40 \mathrm{~min}$. Triisopropyl silyl chloride (1.15 mL, $5.40 \mathrm{mmol}, 1.0$ equiv) was added dropwise over 1.5 hours at the same temperature and was then warmed to rt during 3 hours. The reaction was quenched by addition of water $(10 \mathrm{~mL})$ and the aqueous layer was extracted with $\mathrm{Et}_{2} \mathrm{O}(3 \times 15 \mathrm{~mL})$. The combined organic extracts were washed with aqueous $\mathrm{HCl}(1.0 \mathrm{M}, 10 \mathrm{~mL})$, dried over $\mathrm{MgSO}_{4}$, filtered and concentrated in vacuo. The crude oil was purified by column chromatography $\left(\mathrm{SiO}_{2}\right.$, pentane) to furnish monosilylated diyne 54 as a colorless oil (640 mg, $2.78 \mathrm{mmol}, 48 \%$ yield).

Monosilylated diyne $54(640 \mathrm{mg}, 2.78 \mathrm{mmol})$ was brominated according to the general procedure, but using 1.3 equiv of NBS (594 mg, $3.34 \mathrm{mmol})$ and 0.3 equiv of $\mathrm{AgNO}_{3}(131 \mathrm{mg}, 0.771 \mathrm{mmol})$. After purification by column chromatography $\left(\mathrm{SiO}_{2}\right.$, pentane), bromo alkyne $\mathbf{6} \mathbf{g}$ was obtained as a colorless oil (803 g, $2.45 \mathrm{mmol}, 95 \%$ yield). ${ }^{1} \mathrm{H} \mathrm{NMR}\left(400 \mathrm{MHz}, \mathrm{CDCl}_{3}\right) \delta 2.36(\mathrm{t}, 2 \mathrm{H}, J=7.0 \mathrm{~Hz}), 2.36$ (t, $2 \mathrm{H}, J=7.3 \mathrm{~Hz}), 1.74$ (quint, $2 \mathrm{H}, J=7.0 \mathrm{~Hz}), 1.10-1.02(\mathrm{~m}, 21 \mathrm{H}) ;{ }^{13} \mathrm{C} \mathrm{NMR}\left(101 \mathrm{MHz}, \mathrm{CDCl}_{3}\right) \delta$ 107.5, 81.1, 79.3, 38.3, 27.6, 19.0, 18.7, 18.6, 11.3; IR 2942 (s), 2893 (m), 2865 (s), 2721 (w), 2172 
(m), $1464(\mathrm{~s}), 1431(\mathrm{~m}), 1384(\mathrm{w}), 1362(\mathrm{w}), 1343(\mathrm{w}), 1326(\mathrm{w}), 1311(\mathrm{w}), 1290(\mathrm{w}), 1241(\mathrm{w}), 1213$

(w), $1135(\mathrm{w}), 1070(\mathrm{w}), 1044(\mathrm{~m}), 1019(\mathrm{~m}), 995(\mathrm{~m}), 919(\mathrm{w}), 883(\mathrm{~s}), 840(\mathrm{w})$; HRMS (ESI) calcd for $\mathrm{C}_{16} \mathrm{H}_{27}{ }^{79} \mathrm{BrSi}[\mathrm{M}+]$ 326.1065; found 326.1058.

\section{(((4-Bromo-2-methylbut-3-yn-2-yl)oxy)methyl)benzene (6h)}

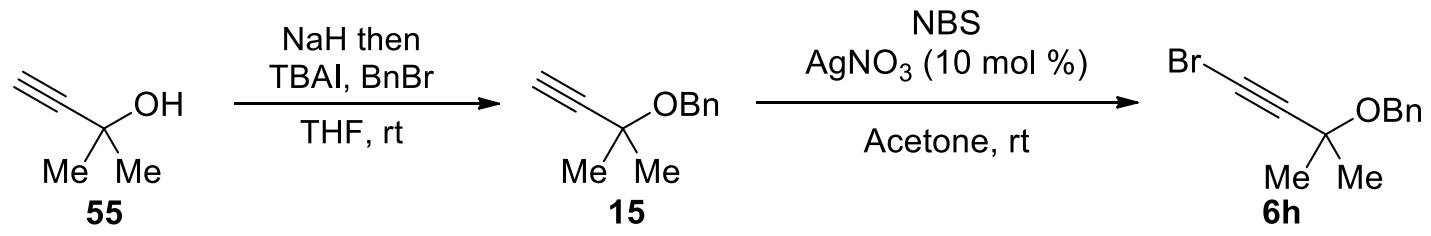

Following a reported procedure, ${ }^{15 \mathrm{c}} \mathrm{NaH}$ (60\% suspension in mineral oil, $240 \mathrm{mg}, 6.00 \mathrm{mmol}, 1.2$ equiv) was added portionwise to a solution of 2-methyl-3-butyn-2-ol (55) (0.49 mL, $5.0 \mathrm{mmol}, 1.0$ equiv) in THF (24 mL). The mixture was stirred at $\mathrm{rt}$ for 1 hour and then TBAI (92.0 mg, $0.250 \mathrm{mmol}$, 0.050 equiv) and benzyl bromide $(0.72 \mathrm{~mL}, 6.0 \mathrm{mmol}, 1.2$ equiv) were added in this order. The reaction mixture was stirred at $\mathrm{rt}$ overnight and then diluted with $\mathrm{Et}_{2} \mathrm{O}(18 \mathrm{~mL})$. The organic solution was washed with water $(3 \times 15 \mathrm{~mL})$, brine and dried over $\mathrm{MgSO}_{4}$. Upon filtration, it was concentrated by evaporation under reduced pressure and the resulting crude oil was purified by column chromatography $\left(\mathrm{SiO}_{2}\right.$, Pentane/Et $\left.2 \mathrm{O} 95 / 5\right)$ to afford the pure O-benzylated alcohol 15 as a colorless oil (715 $\mathrm{mg}, 4.10$ mmol, $82 \%$ yield) which was directly used in the next step.

O-Benzylated alcohol $15(523 \mathrm{mg}, 3.00 \mathrm{mmol})$ was brominated according to the general procedure. After purification by column chromatography ( $\mathrm{SiO}_{2}$, Pentane/EtOAc 98/2), bromoalkyne $6 \mathbf{h}$ was obtained as a pale yellow oil (631 mg, $2.49 \mathrm{mmol}, 83 \%$ yield). ${ }^{1} \mathrm{H} \mathrm{NMR}\left(400 \mathrm{MHz}, \mathrm{CDCl}_{3}\right) \delta$ 7.41-7.31 (m, $4 \mathrm{H}), 7.27(\mathrm{~m}, 1 \mathrm{H}), 4.62(\mathrm{~s}, 2 \mathrm{H}), 1.55(\mathrm{~s}, 6 \mathrm{H}) ;{ }^{13} \mathrm{C} \mathrm{NMR}\left(101 \mathrm{MHz}, \mathrm{CDCl}_{3}\right) \delta 138.7,128.3,127.7$, 127.4, 82.4, 71.7, 66.7, 44.1, 28.7; IR 3065 (w), 3031 (w), 2985 (w), 2934 (w), $2864(w), 2210(w)$, $1496(w), 1454(w), 1436(w), 1382(w), 1361(w), 1235(\mathrm{~m}), 1186(\mathrm{~m}), 1157(\mathrm{~s}), 1086(\mathrm{~m}), 1055$ (s), 1030 (m), $1003(w), 960$ (w), 894 (w); HRMS (ESI) calcd for $\mathrm{C}_{12} \mathrm{H}_{13}{ }^{79} \mathrm{BrO}$ [M] 252.0150; found . 252.0144 . 


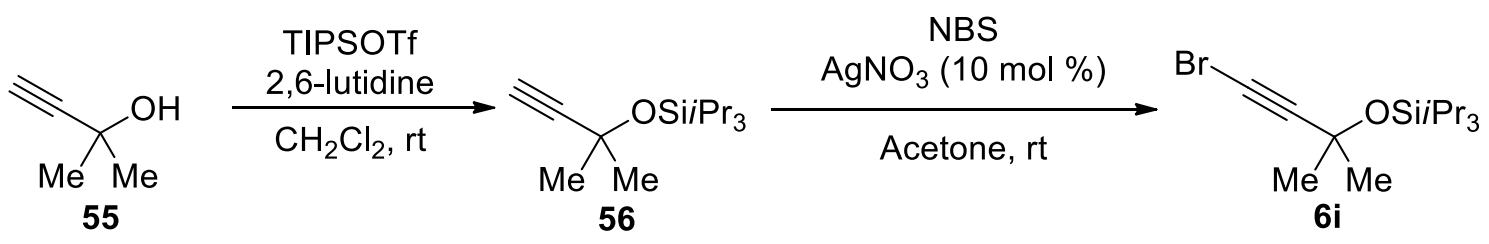

Following a reported procedure, ${ }^{15 \mathrm{~h}}$ 2-methylbut-3-yn-2-ol (55) $(0.34 \mathrm{~mL}, 3.5 \mathrm{mmol}, 1.0$ equiv.) and 2,6-lutidine (freshly distilled on $\mathrm{CaH}_{2}, 0.41 \mathrm{~mL}, 3.5 \mathrm{mmol}, 1.0$ equiv.) were dissolved in $\mathrm{CH}_{2} \mathrm{Cl}_{2}(12$ $\mathrm{mL})$. TIPSOTf $\left(0.94 \mathrm{~mL}, 3.5 \mathrm{mmol}, 1.0\right.$ equiv.) was added dropwise to the solution at $0{ }^{\circ} \mathrm{C}$. The solution was allowed to warm to rt overnight and then quenched with a saturated aqueous $\mathrm{NaHCO}_{3}$ solution and the aqueous layer was extracted with $\mathrm{CH}_{2} \mathrm{Cl}_{2}(3 \times 10 \mathrm{~mL})$. The combined organic layers were washed with $\mathrm{H}_{2} \mathrm{O}$, dried over $\mathrm{MgSO}_{4}$, filtered and the solvent was removed in vacuo. Purification by column chromatography ( $\mathrm{SiO}_{2}$, pentane) afforded TIPS-protected propargyl alcohol $\mathbf{5 6}$ as a colorless oil (622 mg, $2.59 \mathrm{mmol}, 74 \%$ yield), which was used directly for the next step.

Propargyl alcohol 56 (603 mg, $2.51 \mathrm{mmol}, 1.0$ equiv.) was brominated according to the general procedure. After purification by column chromatography $\left(\mathrm{SiO}_{2}\right.$, pentane), bromoalkyne $\mathbf{6} \mathbf{i}$ was obtained as a colorless oil (733 mg, $2.30 \mathrm{mmol}, 91 \%$ yield). $\mathrm{R}_{\mathrm{f}} 0.91$ (Hexane); ${ }^{1} \mathrm{H} \mathrm{NMR}\left(400 \mathrm{MHz}, \mathrm{CDCl}_{3}\right) \delta$ $1.51(\mathrm{~s}, 6 \mathrm{H}), 1.18-1.03(\mathrm{~m}, 21 \mathrm{H}) ;{ }^{13} \mathrm{C} \mathrm{NMR}\left(101 \mathrm{MHz}, \mathrm{CDCl}_{3}\right) \delta 85.4,67.2,42.7,32.9,18.3,13.0 ; \mathrm{IR}$ $2982(w), 2962(w), 2961(w), 2943(\mathrm{~m}), 2892(w), 2866(\mathrm{~m}), 2214(\mathrm{w}), 1748(w), 1741(\mathrm{w}), 1740(\mathrm{w})$, $1724(\mathrm{w}), 1464(\mathrm{~m}), 1379(\mathrm{w}), 1361(\mathrm{w}), 1230(\mathrm{~m}), 1205(\mathrm{w}), 1164(\mathrm{~s}), 1050(\mathrm{~s}), 1016(\mathrm{w}), 997(\mathrm{w}), 996$ (w), 953 (w), 937 (w), 909 (m), 882 (s), 842 (w); HRMS (APPI) calcd for $\mathrm{C}_{14}{ }^{79} \mathrm{BrH}_{27} \mathrm{OSi} 318.1009$ [M]; found 318.1011.

\section{(((1-Bromonon-1-yn-3-yl)oxy)methyl)benzene (6j)}




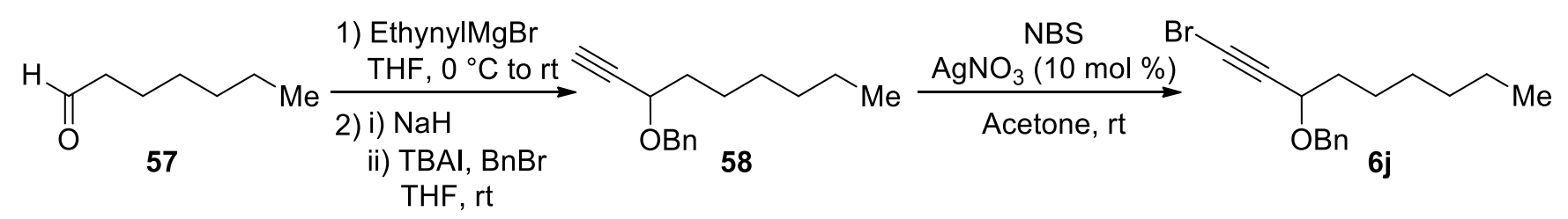

Following a slightly modified reported procedure, ${ }^{15 \mathrm{~d}}$ heptaldehyde $(\mathbf{5 7})(1.22 \mathrm{~mL}, 8.76 \mathrm{mmol}$, 1.0 equiv.) was added dropwise to a solution of ethynyl magnesium bromide (0.5 M in THF, $22.8 \mathrm{~mL}$, 11.4 mmol, 1.3 equiv.) at $0{ }^{\circ} \mathrm{C}$. After $30 \mathrm{~min}$, the cooling bath was removed to reach $\mathrm{rt}$ and the solution was stirred for further $2 \mathrm{~h}$. The reaction was then quenched by addition of aqueous $\mathrm{HCl}(1.0 \mathrm{M}, 15 \mathrm{~mL})$ and the mixture was extracted with $\mathrm{Et}_{2} \mathrm{O}(3 \times 20 \mathrm{~mL})$. The combined organic layers were washed with brine, dried over $\mathrm{MgSO}_{4}$, filtered and the solvent was removed in vacuo. Purification by column chromatography $\left(\mathrm{SiO}_{2}\right.$, pentane/EtOAc 20/1) afforded the corresponding propargyl alcohol as a yellow oil (943 mg, $6.73 \mathrm{mmol}, 77 \%$ yield).

Following a reported procedure, ${ }^{15 \mathrm{c}}$ the propargyl alcohol $(701 \mathrm{mg}, 5.00 \mathrm{mmol}, 1.0$ equiv.) was added dropwise to a suspension of $\mathrm{NaH}(168 \mathrm{mg}, 7.00 \mathrm{mmol}, 1.4$ equiv.) in THF (24 mL). The solution was stirred for $2 \mathrm{~h}$ and then TBAI $(92.3 \mathrm{mg}, 0.250 \mathrm{mmol}, 0.05$ equiv.) and benzyl bromide $(0.84 \mathrm{~mL}$, 7.0 mmol, 1.4 equiv.) were added sequentially. The resulting mixture was stirred overnight and then quenched by slow addition of $\mathrm{H}_{2} \mathrm{O}$. The aqueous layer was extracted with $\mathrm{Et}_{2} \mathrm{O}(3 \times 40 \mathrm{~mL})$ and the combined organic layers were washed with brine, dried over $\mathrm{MgSO}_{4}$, filtered and the solvent was removed in vacuo. Purification by column chromatography $\left(\mathrm{SiO}_{2}\right.$, pentane/EtOAc 20/1) afforded the $O$ benzylated propargyl alcohol $\mathbf{5 8}$ as a yellow oil (1.12 $\mathrm{mg}, 4.86 \mathrm{mmol}, 97 \%$ yield).

Propargyl alcohol 58 (1.12 g, $4.86 \mathrm{mmol}, 1.0$ equiv.) was brominated according to the general procedure. After purification by chromatography column $\left(\mathrm{SiO}_{2}\right.$, Pentane/EtOAc 98/2), bromoalkyne $\mathbf{6 j}$ was obtained as a pale yellow oil (1.06 g, $3.43 \mathrm{mmol}, 71 \%$ yield). $\mathrm{R}_{\mathrm{f}} 0.66$ (Hexane/EtOAc 10/1); ${ }^{1} \mathrm{H}$ NMR (400 MHz, $\left.\mathrm{CDCl}_{3}\right) \delta$ 7.37-7.27 (m, $\left.5 \mathrm{H}\right), 4.78(\mathrm{~d}, 1 \mathrm{H}, J=11.7 \mathrm{~Hz}), 4.49(\mathrm{~d}, 1 \mathrm{H}, J=11.7 \mathrm{~Hz})$, $4.09(\mathrm{t}, 1 \mathrm{H}, J=6.6 \mathrm{~Hz}), 1.74(\mathrm{ddd}, 2 \mathrm{H}, J=13.2,6.6,2.0 \mathrm{~Hz}), 1.44(\mathrm{~m}, 2 \mathrm{H}), 1.35-1.25(\mathrm{~m}, 6 \mathrm{H}), 0.88$ 
(t, $3 \mathrm{H}, J=6.7 \mathrm{~Hz}) ;{ }^{13} \mathrm{C}$ NMR $\left(101 \mathrm{MHz}, \mathrm{CDCl}_{3}\right) \delta 137.8,128.4,128.0,127.7,79.5,70.7,69.6,45.1$, 35.6, 31.7, 28.9, 25.2, 22.6, 14.1; IR 3031 (w), 2953 (s), 2928 (s), 2857 (s), 2207 (w), 1726 (w), 1725 (w), $1705(w), 1497(w), 1456(s), 1391(w), 1377(w), 1333(\mathrm{~m}), 1206(w), 1120(w), 1092(\mathrm{~s}), 1071$ (s), 1029 (m), 990 (w), $910(w), 846$ (w); HRMS (ESI) calcd for $\mathrm{C}_{16}{ }^{79} \mathrm{BrH}_{22} \mathrm{O}^{+}[\mathrm{M}+\mathrm{H}]^{+}$309.0849; found 309.0857.

\section{((1-Bromonon-1-yn-3-yl)oxy)triisopropylsilane (6k)}

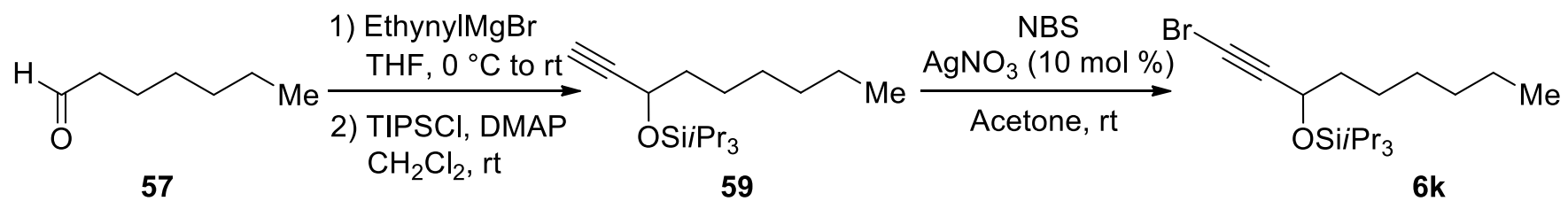

Following a slightly modified reported procedure, ${ }^{15 \mathrm{~d}}$ heptaldehyde $(\mathbf{5 7})(1.22 \mathrm{~mL}, 8.76 \mathrm{mmol}$, 1.0 equiv.) was added dropwise to a solution of ethynyl magnesium bromide (0.5 M in THF, $22.8 \mathrm{~mL}$, $11.4 \mathrm{mmol}, 1.3$ equiv.) at $0{ }^{\circ} \mathrm{C}$. After $30 \mathrm{~min}$, the cooling bath was removed to reach $\mathrm{rt}$ and the solution was stirred for further $2 \mathrm{~h}$. The reaction was then quenched by addition of aqueous $\mathrm{HCl}(1.0 \mathrm{M}, 15 \mathrm{~mL})$ and the mixture was extracted with $\mathrm{Et}_{2} \mathrm{O}(3 \times 20 \mathrm{~mL})$. The combined organic layers were washed with brine, dried over $\mathrm{MgSO}_{4}$, filtered and the solvent was removed in vacuo. Purification by column chromatography $\left(\mathrm{SiO}_{2}\right.$, pentane/EtOAc 20/1) afforded the corresponding propargyl alcohol as a yellow oil (943 mg, $6.73 \mathrm{mmol}, 77 \%$ yield).

TIPSCl (1.36 mL, $6.36 \mathrm{mmol}, 1.1$ equiv.) and DMAP (777 mg, $6.36 \mathrm{mmol}, 1.1$ equiv.) were dissolved in $\mathrm{CH}_{2} \mathrm{Cl}_{2}(10 \mathrm{~mL})$ at $\mathrm{rt}$ and a solution of propargyl alcohol (810 $\mathrm{mg}, 5.78 \mathrm{mmol}, 1.0$ equiv.) in $\mathrm{CH}_{2} \mathrm{Cl}_{2}(30 \mathrm{~mL})$ was slowly added to the reaction mixture. The reaction was stirred overnight and then quenched by sequential addition of $\mathrm{H}_{2} \mathrm{O}(36 \mathrm{~mL})$ and aqueous $\mathrm{HCl}(2.0 \mathrm{M}, 36 \mathrm{~mL})$. The mixture was extracted with $\mathrm{CH}_{2} \mathrm{Cl}_{2}(3 \times 20 \mathrm{~mL})$ and the combined organic layers were washed with brine, dried over $\mathrm{MgSO}_{4}$, filtered and the solvent was removed in vacuo. Purification by column chromatography 
$\left(\mathrm{SiO}_{2}\right.$, Pentane) afforded the O-silylated propargyl alcohol 59 as a colorless oil (1.04 g, $3.51 \mathrm{mmol}, 61 \%$ yield).

O-Silylated propargyl alcohol 59 (890 mg, $3.00 \mathrm{mmol}, 1.0$ equiv.) was brominated according to the general procedure. After purification by column chromatography $\left(\mathrm{SiO}_{2}\right.$, pentane), bromo alkyne $6 \mathbf{k}$ was obtained as a colorless oil (1.04 g, $2.77 \mathrm{mmol}, 92 \%$ yield). $\mathrm{R}_{\mathrm{f}} 0.63$ (Hexane); ${ }^{1} \mathrm{H}$ NMR (400 MHz, $\left.\mathrm{CDCl}_{3}\right) \delta 4.48(\mathrm{t}, 1 \mathrm{H}, J=6.3 \mathrm{~Hz}), 1.69(\mathrm{~m}, 2 \mathrm{H}), 1.44(\mathrm{~m}, 2 \mathrm{H}), 1.36-1.26(\mathrm{~m}, 6 \mathrm{H}), 1.17-1.04(\mathrm{~m}, 21$ H), $0.89(\mathrm{t}, J=6.7 \mathrm{~Hz}) ;{ }^{13} \mathrm{C} \mathrm{NMR}\left(101 \mathrm{MHz}, \mathrm{CDCl}_{3}\right) \delta 82.1,64.0,43.6,38.7,31.8,29.0,24.9,22.6$, 18.0, 18.0, 14.1, 12.3; IR 2942 (s), 2928 (s), 2894 (m), 2866 (s), 2212 (w), 1598 (w), 1597 (w), 1597 (w), $1596(w), 1592$ (w), $1591(w), 1464$ (m), 1383 (w), $1367(w), 1339(w), 1260(w), 1259(w), 1119$ (m), 1096 (s), 1067 (s), 1014 (m), 998 (m), 971 (w), 920 (w), 883 (s); HRMS (ESI) calcd for $\mathrm{C}_{18}{ }^{79} \mathrm{BrH}_{36} \mathrm{OSi}^{+}[\mathrm{M}+\mathrm{H}]^{+}$375.1713; found 375.1724 .

\section{1,9-Dibromonon-1-yne (6l)}

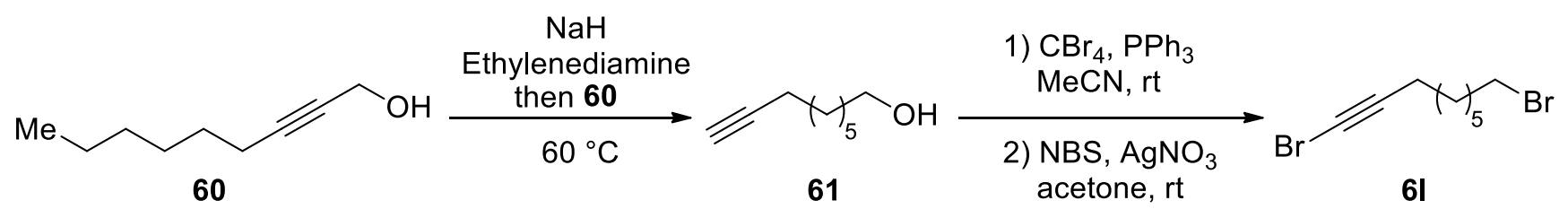

Following a reported procedure, ${ }^{15 \mathrm{f}} \mathrm{NaH}(60 \%$ suspension in mineral oil, $1.28 \mathrm{~g}, 32.0 \mathrm{mmol}, 4.0$ equiv) was added to ethylene diamine (freshly distilled from $\mathrm{KOH}, 14.4 \mathrm{~mL}$ ) and the resulting mixture was stirred at rt for 1 hour. During this time, it became brown and, after being stirred at $60{ }^{\circ} \mathrm{C}$ during an additional hour, it finally converted into a turbid violet solution. It was then cooled to $40{ }^{\circ} \mathrm{C}$ and 3 nonyn-1-ol (60) (1.27 mL, $8.00 \mathrm{mmol}, 1.0$ equiv) was added dropwise. The mixture was then heated back to $60{ }^{\circ} \mathrm{C}$ and stirred at this temperature for 2 hours. Passed this time, the mixture was allowed to cool down to rt and aqueous $\mathrm{HCl}(1.0 \mathrm{M}, 15 \mathrm{~mL})$ was added. The aqueous layer was separated and extracted with $\mathrm{Et}_{2} \mathrm{O}(3 \times 20 \mathrm{~mL})$. The combined organic extracts were dried over $\mathrm{MgSO}_{4}$, filtered and concentrated in vacuo. The crude oil was purified by column chromatography $\left(\mathrm{SiO}_{2}\right.$, Pentane/EtOAc 95/5 
to 70/30) to furnish 8-nonyn-1-ol (61) as a yellow oil (856 mg, $6.10 \mathrm{mmol}$, 76\% yield) which was used directly in the next step.

Alcohol 61 (280 mg, $2.00 \mathrm{mmol}, 1.0$ equiv) was dissolved in acetonitrile (6.8 mL). Triphenyl phosphine (787 mg, $3.00 \mathrm{mmol}, 1.5$ equiv) and tetrabromo methane (997 $\mathrm{mg}, 3.00 \mathrm{mmol}, 1.5$ equiv) were added in this order and the mixture was stirred at $\mathrm{rt}$ for 1 hour. The reaction was quenched by addition of aqueous $\mathrm{NaOH}\left(15 \%\right.$ w/w) until $\mathrm{pH} 9$ and the aqueous layer was extracted with $\mathrm{Et}_{2} \mathrm{O}(3 \times 10$ $\mathrm{mL}$ ). The combined organic extracts were dried over $\mathrm{MgSO}_{4}$, filtered and concentrated in vacuo. The crude oil was purified by column chromatography $\left(\mathrm{SiO}_{2}\right.$, Pentane/EtOAc 95/5) to furnish the corresponding alkyl bromide as a yellow oil (404 mg, $1.99 \mathrm{mmol}$, quantitative), which was used directly in the following step.

The obtained alkyl bromide (404 mg, $1.99 \mathrm{mmol}$ ) was brominated according to the general procedure. After purification by column chromatography $\left(\mathrm{SiO}_{2}\right.$, pentane), dibromo alkyne $\mathbf{6}$ was obtained as a colorless oil (422 g, $1.49 \mathrm{mmol}, 75 \%$ yield). $\mathrm{R}_{\mathrm{f}} 0.44$ (Hexane); ${ }^{1} \mathrm{H}$ NMR (400 MHz, $\left.\mathrm{CDCl}_{3}\right) \delta 3.41$ (t, $2 \mathrm{H}, J=6.8 \mathrm{~Hz}), 2.21(\mathrm{t}, 2 \mathrm{H}, J=6.9 \mathrm{~Hz}), 1.86$ (quint, $2 \mathrm{H}, J=6.5 \mathrm{~Hz}), 1.52(\mathrm{~m}, 2 \mathrm{H}), 1.47-1.28(\mathrm{~m}$, $6 \mathrm{H}) ;{ }^{13} \mathrm{C} \mathrm{NMR}\left(101 \mathrm{MHz}, \mathrm{CDCl}_{3}\right) \delta 80.3,37.6,33.9,32.7,28.5,28.2,28.1,28.0,19.6$; IR 2951 (m), $2929(\mathrm{~m}), 2900$ (w), $2856(\mathrm{~m}), 1599(\mathrm{w}), 1490(\mathrm{w}), 1471(\mathrm{w}), 1464(\mathrm{w}), 1442(\mathrm{w}), 1433(\mathrm{w}), 1433(\mathrm{w})$, $1407(w), 1389(w), 1389(w), 1361(w), 1361(w), 1352(w), 1254(\mathrm{~m}), 1223(\mathrm{w}), 1189(\mathrm{w}), 1105$ (s), $1071(\mathrm{~m}), 1029$ (w), 1007 (w), 1007 (w), 982 (w), 954 (w), 912 (w), 835 (s), 816 (w); Anal. Calcd. for $\mathrm{C}_{9} \mathrm{H}_{14} \mathrm{Br}_{2}: \mathrm{C}, 38.33 \%$; H, 5.00\%. Found: C, 38.69\%; H, 5.08\%.

\section{General procedure for the oxy- and amino- alkynylation reaction:}

Under inert atmosphere, $\mathrm{Pd}(\mathrm{dba})_{2}(11.5 \mathrm{mg}, 0.0200 \mathrm{mmol}, 0.05$ equiv), DPEPHos (16.1 mg, 0.0300 mmol, 0.075 equiv) and $\mathrm{NaO} t \mathrm{Bu}(50.0 \mathrm{mg}, 0.520 \mathrm{mmol}, 1.3$ equiv) were introduced into a $5 \mathrm{~mL}$ vial, which was then sealed. Toluene was added $(4.6 \mathrm{~mL})$, followed by the bromo acetylene $(0.520 \mathrm{mmol}, 1.3$ equiv) and the starting material $\left(0.40 \mathrm{mmol}, 1.0\right.$ equiv). The mixture was stirred at $80{ }^{\circ} \mathrm{C}$ for $3 \mathrm{~h}$ and 
then allowed to cool to room temperature. The solvent was evaporated under reduced pressure. The crude mixture was then directly purified by column chromatography ( $\mathrm{SiO}_{2}$, pentane/EtOAc $98 / 2$ to 96/4).

\section{General procedure for the deprotection of 2-propargyl N-Boc pyrrolidines:}

The N-Boc pyrrolidines $\mathbf{1 0}$ (1.0 equiv) is dissolved in $\mathrm{CH}_{2} \mathrm{Cl}_{2}(20 \mathrm{~mL}$ per mmol of protected pyrrolidine) and the resulting solution is cooled to $0{ }^{\circ} \mathrm{C}$. Trifluoroacetic acid $(10 \mathrm{~mL}$ per mmol of protected pyrrolidine) was added dropwise and the mixture was stirred at $0{ }^{\circ} \mathrm{C}$ for $40 \mathrm{~min}$. The volatiles were then removed by distillation under reduced pressure. The residue was taken up in $\mathrm{CH}_{2} \mathrm{Cl}_{2}$ and the solution as washed with aqueous $\mathrm{NaOH}\left(2 \mathrm{M}\right.$, three times). The combined organic layers were dried over $\mathrm{Na}_{2} \mathrm{SO}_{4}$, filtered and concentrated under reduced pressure.

2-(Non-2-yn-1-yl)tetrahydrofuran (7aa): was prepared from 4-penten-1-ol (5a) (34.4 mg, 0.400 mmol) and octynyl bromide $(\mathbf{6 a})(98.0 \mathrm{mg}, 0.521 \mathrm{mmol})$. It was obtained as a colorless oil $(56.4 \mathrm{mg}$, $0.291 \mathrm{mmol}, 69 \%$ yield). $\mathrm{R}_{\mathrm{f}} 0.54$ (Hexane/EtOAc 5/1); ${ }^{1} \mathrm{H}$ NMR (400 MHz, $\left.\mathrm{CDCl}_{3}\right) \delta 3.99$ (ddd, $1 \mathrm{H}, J$ $=12.2,6.7,6.7 \mathrm{~Hz}), 3.90(\mathrm{ddd}, 1 \mathrm{H}, J=8.2,7.0,7.0 \mathrm{~Hz}), 3.76(\mathrm{ddd}, 1 \mathrm{H}, J=7.7,7.7,6.4 \mathrm{~Hz}), 2.43$ (ddt, $1 \mathrm{H}, J=16.4,5.1,2.4 \mathrm{~Hz}), 2.33(\mathrm{ddt}, 1 \mathrm{H}, J=16.4,6.7,2.4 \mathrm{~Hz}), 2.15(\mathrm{tt}, 2 \mathrm{H}, J=7.0,2.4 \mathrm{~Hz}), 2.02(\mathrm{~m}$, $1 \mathrm{H}), 1.90(\mathrm{~m}, 2 \mathrm{H}), 1.69$ (ddt, $1 \mathrm{H}, J=12.0,8.7,7.0 \mathrm{~Hz}$ ), 1.48 (quint, $2 \mathrm{H}, J=7.0 \mathrm{~Hz}$ ), 1.41-1.21 (m, 6 $\mathrm{H}), 0.88(\mathrm{t}, 3 \mathrm{H}, J=6.8 \mathrm{~Hz}) ;{ }^{13} \mathrm{C} \mathrm{NMR}\left(101 \mathrm{MHz}, \mathrm{CDCl}_{3}\right) \delta 81.6,77.7,76.5,68.4,31.3,30.7,29.0$, 28.5, 25.7, 25.6, 22.5, 18.8, 14.0; IR $2956(\mathrm{~m}), 2928(\mathrm{~m}), 2857(\mathrm{~m}), 1690(\mathrm{w}), 1460(\mathrm{w}), 1436(\mathrm{w}), 1435$ (w), $1378(w), 1369(w), 1183(w), 1110(w), 1069($ s), $920(w), 877(w), 844(w), 831(w), 816(w)$; HRMS (ESI) calcd for $\mathrm{C}_{16} \mathrm{H}_{30} \mathrm{AgOSi}^{+}[\mathrm{M}+\mathrm{H}]^{+}$195.1743; found 195.1741.

tert-Butyldiphenyl((6-(tetrahydrofuran-2-yl)hex-4-yn-1-yl)oxy)silane (7ad): was prepared from 4penten-1-ol (5a) (34.4 mg, $0.400 \mathrm{mmol})$ and alkynyl bromide $6 \mathbf{d}$ (208 mg, $0.519 \mathrm{mmol})$. It was obtained as a colorless oil (109 mg, $0.269 \mathrm{mmol}, 67 \%$ yield). $\mathrm{R}_{\mathrm{f}} 0.49$ (Hexane/EtOAc 5/1); ${ }^{1} \mathrm{H}$ NMR (400 MHz, $\left.\mathrm{CDCl}_{3}\right) \delta 7.67(\mathrm{~m}, 4 \mathrm{H}), 7.45-7.34(\mathrm{~m}, 6 \mathrm{H}), 3.95(\mathrm{ddd}, 1 \mathrm{H}, J=12.3,6.7,6.7 \mathrm{~Hz}), 3.88(\mathrm{~m}, 1 \mathrm{H}), 3.78-$ $3.70(\mathrm{~m}, 1 \mathrm{H}), 3.73(\mathrm{t}, 2 \mathrm{H}, J=6.1 \mathrm{~Hz}), 2.40(\mathrm{ddd}, 1 \mathrm{H}, J=13.7,5.3,2.3 \mathrm{~Hz}), 2.34-2.26(\mathrm{~m}, 3 \mathrm{H}), 1.98$ 
(m, $1 \mathrm{H}), 1.94-1.80(\mathrm{~m}, 2 \mathrm{H}), 1.74$ (quint, $2 \mathrm{H}, J=6.7 \mathrm{~Hz}), 1.63$ (dddd, $1 \mathrm{H}, J=12.3,8.8,7.0,7.0 \mathrm{~Hz}$ ), $1.05(\mathrm{~s}, 9 \mathrm{H}) ;{ }^{13} \mathrm{C} \mathrm{NMR}\left(101 \mathrm{MHz}, \mathrm{CDCl}_{3}\right) \delta 135.9,134.2,129.8,127.9,81.3,78.0,77.1,68.7,62.9$, 32.2, 31.0, 27.1, 26.0, 25.9, 19.5, 15.7; IR 3070 (w), 3049 (w), $3026(w), 3015(w), 2997(w), 2953(w)$, $2931(\mathrm{~m}), 2857(\mathrm{w}), 1590(\mathrm{w}), 1488(\mathrm{w}), 1473(\mathrm{w}), 1463(\mathrm{w}), 1446(\mathrm{w}), 1429(\mathrm{~m}), 1390(\mathrm{w}), 1361(\mathrm{w})$, $1189(\mathrm{w}), 1140(\mathrm{w}), 1108$ (s), 1068 (s), 1032 (w), 1009 (w), $999(\mathrm{w}), 975(\mathrm{w}), 963(\mathrm{w}), 938(\mathrm{w}), 911$ (m), $910(\mathrm{~m}), 823(\mathrm{~m})$; HRMS (ESI) calcd for $\mathrm{C}_{26} \mathrm{H}_{35} \mathrm{O}_{2} \mathrm{Si}^{+}[\mathrm{M}+\mathrm{H}]^{+}$407.2401; found 407.2385.

2-(6-Phenylhex-2-yn-1-yl)tetrahydrofuran (7ae): was prepared from 4-penten-1-ol (5a) (34.4 mg, $0.400 \mathrm{mmol})$ and alkynyl bromide $6 \mathbf{e}(116 \mathrm{mg}, 0.520 \mathrm{mmol})$. It was obtained as a pale yellow oil (58.0 $\mathrm{mg}, 0.254 \mathrm{mmol}, 64 \%$ yield). $\mathrm{R}_{\mathrm{f}} 0.67$ (Hexane/EtOAc 5/1); ${ }^{1} \mathrm{H}$ NMR (400 MHz, $\left.\mathrm{CDCl}_{3}\right) \delta 7.28(\mathrm{~m}, 2$ H), 7.21-7.16 (m, $3 \mathrm{H}), 4.01$ (ddd, $1 \mathrm{H}, J=13.5,6.7,5.5 \mathrm{~Hz}), 3.92(\mathrm{ddd}, 1 \mathrm{H}, J=8.2,7.0,6.4 \mathrm{~Hz}), 3.77$ (ddd, $1 \mathrm{H}, J=8.1,7.5,6.3 \mathrm{~Hz}), 2.72(\mathrm{t}, 2 \mathrm{H}, J=7.5 \mathrm{~Hz}), 2.46$ (dddd, $1 \mathrm{H}, J=16.4,5.4,2.4,2.4 \mathrm{~Hz}$ ), 2.37 (dddd, $1 \mathrm{H}, J=16.4,6.7,2.4,2.4 \mathrm{~Hz}), 2.22-2.16$ (m, $2 \mathrm{H}), 2.05$ (m, $1 \mathrm{H}), 1.99-1.86$ (m, $2 \mathrm{H}), 1.81$ (quint, $2 \mathrm{H}, J=6.9 \mathrm{~Hz}), 1.72(\mathrm{~m}, 1 \mathrm{H}) ;{ }^{13} \mathrm{C} \mathrm{NMR}\left(101 \mathrm{MHz}, \mathrm{CDCl}_{3}\right) \delta 141.8,128.5,128.3,125.8,81.0$, 77.6, 77.2, 68.4, 34.8, 30.7, 30.6, 25.7, 25.6, 18.3; IR 3025 (w), 2973 (w), 2943 (w), 2942 (w), 2929 (w), $2909(w), 2903(w), 2885(w), 2884(w), 2863(w), 1603(w), 1496(w), 1455(w), 1434(w), 1408$ (w), $1394(w), 1370(w), 1332(w), 1313(w), 1251(w), 1243(w), 1234(w), 1233(w), 1179(w), 1067$ (s), $1032(w), 1014(w), 1013(w), 1009(w), 996(w), 984(w), 967(w), 945(w), 911(w), 880(w), 873$ (w), $844(w), 838(w), 832(w)$; HRMS (ESI) calcd for $\mathrm{C}_{16} \mathrm{H}_{21} \mathrm{O}^{+}[\mathrm{M}+\mathrm{H}]^{+}$229.1587; found 229.1586.

2-(6-Chlorohex-2-yn-1-yl)tetrahydrofuran (7af): was prepared from 4- penten-1-ol (5a) (34.4 mg, $0.400 \mathrm{mmol})$ and alkynyl bromide $\mathbf{6 f}(94.4 \mathrm{mg}, 0.520 \mathrm{mmol})$. It was obtained as a pale yellow oil (41.5 mg, 0.222 mmol, 56\% yield). $\mathrm{R}_{\mathrm{f}} 0.53$ (Hexane/EtOAc 5/1); ${ }^{1} \mathrm{H} \mathrm{NMR}\left(400 \mathrm{MHz}, \mathrm{CDCl}_{3}\right) \delta 3.98$ (quint, 1 $\mathrm{H}, J=6.5 \mathrm{~Hz}), 3.90(\mathrm{ddd}, 1 \mathrm{H}, J=8.5,7.0,7.0 \mathrm{~Hz}), 3.76(\mathrm{ddd}, 1 \mathrm{H}, J=7.5,6.5,6.5 \mathrm{~Hz}), 3.64(\mathrm{t}, 2 \mathrm{H}, J$ = 6.5 Hz), 2.45-2.30 (m, $4 \mathrm{H}), 2.03(\mathrm{~m}, 1 \mathrm{H}), 1.97-1.82(\mathrm{~m}, 2 \mathrm{H}), 1.92$ (quint, $2 \mathrm{H}, J=6.5 \mathrm{~Hz}), 1.65(\mathrm{~m}$, $1 \mathrm{H}) ;{ }^{13} \mathrm{C} \mathrm{NMR}\left(101 \mathrm{MHz}, \mathrm{CDCl}_{3}\right) \delta 79.4,77.8,77.5,68.4,43.7,31.6,30.7,25.7,25.5,16.2 ; \mathrm{IR} 2961$ (w), $2953(w), 2952(w), 2951(w), 2926(w), 2914(w), 2869(w), 1457(w), 1441(w), 1435(w), 1369$ 
(w), $1358(w), 1357(w), 1331(w), 1330(w), 1307(w), 1292(w), 1272(w), 1110(w), 1067(s), 1009$

(w), $987(w), 972(w), 971(w), 913(\mathrm{~m}), 861(w)$. HRMS (ESI) calcd for $\mathrm{C}_{10}{ }^{37} \mathrm{ClH}_{16} \mathrm{O}^{+}[\mathrm{M}+\mathrm{H}]^{+}$ 187.0884; found 187.0889.

Triisopropyl(8-(tetrahydrofuran-2-yl)octa-1,6-diyn-1-yl)silane (7ag): was prepared from 4- penten-1-ol (5a) (34.4 mg, $0.400 \mathrm{mmol})$ and alkynyl bromide $\mathbf{6 g}$ (170 $\mathrm{mg}, 0.520 \mathrm{mmol})$. It was obtained as a pale yellow oil (76.7 mg, $0.230 \mathrm{mmol}, 59 \%$ yield). $\mathrm{R}_{\mathrm{f}} 0.34$ (Hexane/EtOAc 20/1); ${ }^{1} \mathrm{H}$ NMR (400 $\left.\mathrm{MHz}, \mathrm{CDCl}_{3}\right) \delta 3.98(\mathrm{ddd}, 1 \mathrm{H}, J=12.2,6.5,6.5 \mathrm{~Hz}), 3.89(\mathrm{dd}, 1 \mathrm{H}, J=14.7,7.0 \mathrm{~Hz}), 3.75(\mathrm{dd}, 1 \mathrm{H}, J$ = 14.0, $7.4 \mathrm{~Hz}), 2.42(\mathrm{~m}, 1 \mathrm{H}), 2.26-2.38(\mathrm{~m}, 5 \mathrm{H}), 2.02(\mathrm{~m}, 1 \mathrm{H}), 1.90(\mathrm{~m}, 2 \mathrm{H}), 1.75-1.64(\mathrm{~m}, 1 \mathrm{H})$, 1.70 (quint, $J=7.0 \mathrm{~Hz}$ ), 0.97-1.13 (m, $21 \mathrm{H}) ;{ }^{13} \mathrm{C} \mathrm{NMR}\left(101 \mathrm{MHz}, \mathrm{CDCl}_{3}\right) \delta 108.1,80.7,80.5,77.6$, 77.3, 68.4, 30.7, 28.3, 25.7, 25.6, 19.0, 18.6, 17.9, 11.3; IR 2942 (s), 2865 (s), 2361 (w), 2172 (m), 2172 (m), $1684(\mathrm{w}), 1683(\mathrm{w}), 1462(\mathrm{~m}), 1374(\mathrm{w}), 1336(\mathrm{w}), 1320(\mathrm{w}), 1070(\mathrm{~s}), 999(\mathrm{w}), 921(\mathrm{w}), 883(\mathrm{~m})$; HRMS (APPI) calcd for $\mathrm{C}_{21} \mathrm{H}_{36} \mathrm{OSi}[\mathrm{M}] 332.2535$; found 332.2532.

2-(4-(Benzyloxy)-4-methylpent-2-yn-1-yl)tetrahydrofuran (7ah): was prepared from 4- penten-1-ol (5a) (34.4 mg, $0.400 \mathrm{mmol})$ and alkynyl bromide $\mathbf{6 h}(132 \mathrm{mg}, 0.520 \mathrm{mmol})$. It was obtained as a pale yellow oil (87.5 mg, $0.338 \mathrm{mmol}, 85 \%$ yield). $\mathrm{R}_{\mathrm{f}} 0.53$ (Hexane/EtOAc 5/1); ${ }^{1} \mathrm{H}$ NMR (400 MHz, $\left.\mathrm{CDCl}_{3}\right) \delta$ 7.44-7.33 (m, $\left.4 \mathrm{H}\right), 7.29(\mathrm{~m}, 1 \mathrm{H}), 4.66(\mathrm{~s}, 2 \mathrm{H}), 4.06(\mathrm{ddd}, 1 \mathrm{H}, J=13.7,6.9,4.9 \mathrm{~Hz}), 3.94$ (ddd, $1 \mathrm{H}, J=8.2,7.0,7.0 \mathrm{~Hz}), 3.80(\mathrm{ddd}, 1 \mathrm{H}, J=7.4,7.4,6.4 \mathrm{~Hz}), 2.56(\mathrm{dd}, 1 \mathrm{H}, J=16.5,4.8 \mathrm{~Hz})$, $2.45(\mathrm{dd}, 1 \mathrm{H}, J=16.5,7.2 \mathrm{~Hz}), 2.08(\mathrm{~m}, 1 \mathrm{H}), 2.02-1.85(\mathrm{~m}, 2 \mathrm{H}), 1.77$ (ddt, $J=12.0,8.8,7.0 \mathrm{~Hz}), 1.56$ $(\mathrm{s}, 6 \mathrm{H}) ;{ }^{13} \mathrm{C} \mathrm{NMR}\left(101 \mathrm{MHz}, \mathrm{CDCl}_{3}\right) \delta 139.2,128.2,127.6,127.2,83.7,81.2,77.2,70.7,68.5,66.3$, 30.6, 29.1, 25.7, 25.4; IR 3031 (w), 2980 (w), 2934 (w), 2907 (w), 2866 (w), 2865 (w), 2238 (w), 1497 (w), $1455(\mathrm{w}), 1454(\mathrm{w}), 1379(\mathrm{w}), 1360(\mathrm{w}), 1249(\mathrm{w}), 1187(\mathrm{w}), 1156(\mathrm{~m}), 1063(\mathrm{~s}), 1030(\mathrm{w}), 921$ (w), $873(w)$; HRMS (ESI) calcd for $\mathrm{C}_{17} \mathrm{H}_{23} \mathrm{O}_{2}{ }^{+}[\mathrm{M}+\mathrm{H}]^{+}$259.1693; found 259.1704.

\section{Triisopropyl((2-methyl-5-(tetrahydrofuran-2-yl)pent-3-yn-2-yl)oxy)silane (7ai): was prepared} from 4- penten-1-ol (5a) $(34.4 \mathrm{mg}, 0.400 \mathrm{mmol})$ and alkynyl bromide $6 \mathbf{i}$ (166 mg, $0.520 \mathrm{mmol})$. It was obtained as a pale yellow oil $\left(94.0 \mathrm{mg}, 0.290 \mathrm{mmol}, 72 \%\right.$ yield). $\mathrm{R}_{\mathrm{f}} 0.81$ (Hexane/EtOAc 5/1); ${ }^{1} \mathrm{H}$ NMR 
$\left(400 \mathrm{MHz}^{\mathrm{CDCl}}{ }_{3}\right) \delta 3.97(\mathrm{ddd}, 1 \mathrm{H}, J=14.4,6.7,4.8 \mathrm{~Hz}), 3.88(\mathrm{ddd}, 1 \mathrm{H}, J=8.2,7.2,6.3 \mathrm{~Hz}), 3.74$

(ddd, $1 \mathrm{H}, J=8.3,7.4,6.5 \mathrm{~Hz}), 2.47(\mathrm{dd}, 1 \mathrm{H}, J=16.4,4.7 \mathrm{~Hz}), 2.29(\mathrm{dd}, 1 \mathrm{H}, J=16.5,7.9 \mathrm{~Hz}), 2.02$

$(\mathrm{m}, 1 \mathrm{H}), 1.96-1.81(\mathrm{~m}, 2 \mathrm{H}), 1.68(\mathrm{~m}, 1 \mathrm{H}), 1.18-1.00(\mathrm{~m}, 21 \mathrm{H}) ;{ }^{13} \mathrm{C}$ NMR $\left(101 \mathrm{MHz}, \mathrm{CDCl}_{3}\right) \delta 87.1$, 78.9, 77.3, 68.3, 66.2, 33.4, 30.7, 25.7, 25.6, 18.3, 13.0; IR 2961 (m), 2943 (m), 2942 (m), 2890 (w), $2865(\mathrm{~m}), 1754(\mathrm{w}), 1744(\mathrm{w}), 1464(\mathrm{~m}), 1435(\mathrm{w}), 1434(\mathrm{w}), 1377(\mathrm{w}), 1360(\mathrm{w}), 1245(\mathrm{~m}), 1244(\mathrm{~m})$, 1162 (s), 1050 (s), 1049 (s), $1017(w), 996(w), 969$ (w), $956(w), 935(w), 920(w), 904(w), 882(\mathrm{~m})$; HRMS (ESI) calcd for $\mathrm{C}_{19} \mathrm{H}_{37} \mathrm{O}_{2} \mathrm{Si}^{+}[\mathrm{M}+\mathrm{H}]^{+}$325.2557; found 325.2550.

2-(4-(Benzyloxy)dec-2-yn-1-yl)tetrahydrofuran (7aj): was prepared from 4- penten-1-ol (5a) (34.4 $\mathrm{mg}, 0.400 \mathrm{mmol})$ and alkynyl bromide $\mathbf{6 j}(161 \mathrm{mg}, 0.520 \mathrm{mmol})$. It was obtained as a pale yellow oil (79.6 mg, $0.253 \mathrm{mmol}, 63 \%$ yield; inseparable mixture of diastereoisomers, d.r. $1 / 1$ - the differentiation between the two diastereoisomers is only visible in ${ }^{13} \mathrm{C}-\mathrm{NMR}$ spectrum). $\mathrm{R}_{\mathrm{f}} 0.62$ (Hexane/EtOAc 5/1); ${ }^{1} \mathrm{H}$ NMR $\left(400 \mathrm{MHz}, \mathrm{CDCl}_{3}\right) \delta$ 7.41-7.31 (m, $\left.4 \mathrm{H}\right), 7.28(\mathrm{~m}, 1 \mathrm{H}), 4.79(\mathrm{~d}, 1 \mathrm{H}, J=11.8 \mathrm{~Hz}), 4.51(\mathrm{~d}, 1$ $\mathrm{H}, J=11.8 \mathrm{~Hz}), 4.12-4.01(\mathrm{~m}, 3 \mathrm{H}), 3.92(\mathrm{ddd}, 1 \mathrm{H}, J=7.6,6.7,6.7 \mathrm{~Hz}), 3.78(\mathrm{dd}, 1 \mathrm{H}, J=14.1,7.4$ Hz), 2.56 (ddd, $1 \mathrm{H}, J=16.5,4.9,1.8 \mathrm{~Hz}$ ), 2.44 (dddd, $1 \mathrm{H}, J=16.5,7.1,0.9,0.9 \mathrm{~Hz}), 2.06(\mathrm{~m}, 1 \mathrm{H})$, 2.01-1.84 (m, $2 \mathrm{H}), 1.81-1.66$ (m, $3 \mathrm{H}), 1.55-1.38$ (m, $2 \mathrm{H}), 1.40-1.22(\mathrm{~m}, 6 \mathrm{H}), 0.83$ (m, $3 \mathrm{H})$; ${ }^{13} \mathrm{C}$ NMR $\left(101 \mathrm{MHz} \mathrm{CDCl}_{3}\right) \delta 138.2,128.2,127.9,127.5,82.7,80.5,80.5,77.2,70.2,68.9,68.4,36.0,31.7,30.7$, 28.9, 25.7, 25.5, 25.3, 22.5, 14.0; IR 3062 (w), 3027 (w), 2927 (m), 2914 (m), 2908 (m), 2867 (m), 1690 (w), $1651(w), 1645(w), 1634(w), 1624(w), 1604(w), 1586(w), 1557(w), 1543(w), 1496(\mathrm{~m}), 1454$ (s), $1430(\mathrm{~m}), 1406(\mathrm{~m}), 1381(\mathrm{w}), 1357(\mathrm{w}), 1341(\mathrm{w}), 1249(\mathrm{w}), 1199(\mathrm{w}), 1186(\mathrm{w}), 1156(\mathrm{~m}), 1080$ (m), 1059 (s), 1031 (m), 1002 (w), 960 (w), $911(w), 875(w), 840(w), 834(w), 823(w), 812(w)$; HRMS (ESI) calcd for $\mathrm{C}_{21} \mathrm{H}_{31} \mathrm{O}_{2}{ }^{+}[\mathrm{M}+\mathrm{H}]^{+}$315.2319; found 315.2320.

Triisopropyl((1-(tetrahydrofuran-2-yl)dec-2-yn-4-yl)oxy)silane (7ak): was prepared from 4- penten-1-ol (5a) (34.4 mg, $0.400 \mathrm{mmol})$ and alkynyl bromide 6k (199 mg, $0.520 \mathrm{mmol})$. It was obtained as a pale yellow oil (118 mg, $0.310 \mathrm{mmol}, 78 \%$ yield; inseparable mixture of diastereoisomers, d.r. $1 / 1$ the differentiation between the two diastereoisomers is only visible in ${ }^{13} \mathrm{C}-\mathrm{NMR}$ spectrum). $\mathrm{R}_{\mathrm{f}} 0.77$ 
(Hexane/EtOAc 5/1); ${ }^{1} \mathrm{H}$ NMR (400 MHz, $\left.\mathrm{CDCl}_{3}\right) \delta 4.44(\mathrm{~m}, 1 \mathrm{H}), 3.99(\mathrm{ddd}, 1 \mathrm{H}, J=13.9,7.0,4.7$ Hz), $3.88(\mathrm{~m}, 1 \mathrm{H}), 3.75$ (ddd, $1 \mathrm{H}, J=8.2,7.4,6.3 \mathrm{~Hz}), 2.50$ (ddd, $1 \mathrm{H}, J=4.6,2.0,2.0 \mathrm{~Hz}), 2.33$ (ddd, $J=4.6,2.0,2.0 \mathrm{~Hz}), 2.04(\mathrm{~m}, 1 \mathrm{H}), 1.98-1.81(\mathrm{~m}, 2 \mathrm{H}), 1.72(\mathrm{~m}, 1 \mathrm{H}), 1.69-1.62(\mathrm{~m}, 2 \mathrm{H}), 1.49-1.38$ (m, $2 \mathrm{H}), 1.36-1.21(\mathrm{~m}, 6 \mathrm{H}), 1.18-1.03(\mathrm{~m}, 21 \mathrm{H}), 0.89(\mathrm{t}, 3 \mathrm{H}, J=6.7 \mathrm{~Hz}) ;{ }^{13} \mathrm{C} \mathrm{NMR}\left(101 \mathrm{MHz}, \mathrm{CDCl}_{3}\right.$, resolved signals corresponding to different diastereoisomers are reported in italics) ${ }^{31} \delta 83.5,83.5,80.7$, $68.4,68.3,63.2,39.2,31.8,30.7,29.1,25.7,25.7,25.6,25.6,25.0,22.6,18.1,18.0,14.1$; IR 2942 (s), $2895(\mathrm{~m}), 2865(\mathrm{~s}), 1464(\mathrm{~m}), 1383(\mathrm{w}), 1383(\mathrm{w}), 1367(\mathrm{w}), 1341(\mathrm{w}), 1256(\mathrm{w}), 1250(\mathrm{w}), 1151(\mathrm{w})$, 1089 (s), 1070 (s), 1014 (w), 998 (w), 920 (w), 883 (m). ); HRMS (ESI) calcd for $\mathrm{C}_{23} \mathrm{H}_{45} \mathrm{O}_{2} \mathrm{Si}^{+}[\mathrm{M}+\mathrm{H}]^{+}$ 381.3183; found 381.3196 .

2-(4-(Benzyloxy)-4-methylpent-2-yn-1-yl)-5-phenyltetrahydrofuran (7bh): was prepared from alcohol $\mathbf{5 b}(65.0 \mathrm{mg}, 0.401 \mathrm{mmol})$ and alkynyl bromide $\mathbf{6 h}(132 \mathrm{mg}, 0.520 \mathrm{mmol})$. It was obtained as a colorless oil (96.3 mg, $0.288 \mathrm{mmol}, 72 \%$ yield). ${ }^{32} \mathrm{R}_{\mathrm{f}} 0.65$ (Hexane/EtOAc 5/1); ${ }^{1} \mathrm{H}$ NMR (400 MHz, $\left.\mathrm{CDCl}_{3}\right) \delta 7.40-7.28(\mathrm{~m}, 7 \mathrm{H}), 7.28-7.20(\mathrm{~m}, 3 \mathrm{H}), 5.06(\mathrm{dd}, 1 \mathrm{H}, J=7.9,6.7 \mathrm{~Hz}), 4.65(\mathrm{~s}, 2 \mathrm{H}), 4.37$ (ddd, $1 \mathrm{H}, J=13.6,6.9,4.7 \mathrm{~Hz}), 2.62(\mathrm{dd}, 1 \mathrm{H}, J=16.6,4.6 \mathrm{~Hz}), 2.53(\mathrm{dd}, 1 \mathrm{H}, J=16.5,7.2 \mathrm{~Hz}), 2.38$ (m, $1 \mathrm{H}), 2.21(\mathrm{~m}, 1 \mathrm{H}), 2.00-1.82(\mathrm{~m}, 2 \mathrm{H}), 1.54(\mathrm{~s}, 6 \mathrm{H}) ;{ }^{13} \mathrm{C} \mathrm{NMR}\left(101 \mathrm{MHz}, \mathrm{CDCl}_{3}\right) \delta 143.2,139.2$ $128.3,128.3,127.6,127.2,127.2,125.5,84.0,82.2,81.1,77.9,70.8,66.4,35.2,31.5,29.2,25.8$; IR 3063 (w), 3030 (w), 2980 (w), 2933 (w), 2912 (w), $2911(w), 2865$ (w), $1604(w), 1495(w), 1453(w)$, $1380(\mathrm{w}), 1359(\mathrm{w}), 1249(\mathrm{w}), 1186(\mathrm{w}), 1156(\mathrm{~m}), 1084(\mathrm{~m}), 1057(\mathrm{~s}), 1031(\mathrm{~m}), 1002(\mathrm{w}), 967(\mathrm{w})$, 922 (w), 874 (w), 818 (w); HRMS (ESI) HRMS (ESI) calcd for $\mathrm{C}_{23} \mathrm{H}_{27} \mathrm{O}_{2}{ }^{+}[\mathrm{M}+\mathrm{H}]^{+}$335.2006; found 335.2006.

2,5-Di(non-2-yn-1-yl)tetrahydrofuran (7ca): was prepared from alcohol 5c $(77.7 \mathrm{mg}, 0.400 \mathrm{mmol})$ and octynyl bromide $(\mathbf{6 a})(98.0 \mathrm{mg}, 0.521 \mathrm{mmol})$ following the general procedure, but using 0.10 equiv $\mathrm{Pd}(\mathrm{dba})_{2}(23.0 \mathrm{mg}, 0.0400 \mathrm{mmol})$ and 0.15 equiv DPEPHos $(32.3 \mathrm{mg}, 0.0600 \mathrm{mmol})$. It was obtained as a pale yellow oil (69.9 mg, $0.221 \mathrm{mmol}, 55 \%$ yield, 95\% pure; mixture of inseparable diastereoisomers, d.r. trans/cis 87/13). ${ }^{33} \mathrm{R}_{\mathrm{f}} 0.64$ (Hexane/EtOAc 5/1); ${ }^{1} \mathrm{H} \mathrm{NMR}\left(400 \mathrm{MHz}, \mathrm{CDCl}_{3}\right) \delta 4.14$ (m, $\left.2 \mathrm{H}\right), 2.42$ 
(dddd, $2 \mathrm{H}, J=13.1,7.3,2.5,2.5 \mathrm{~Hz}), 2.30(\mathrm{dddd}, 2 \mathrm{H}, J=16.4,7.3,2.4,2.4 \mathrm{~Hz}), 2.16-2.06(\mathrm{~m}, 4 \mathrm{H})$, $1.76(\mathrm{~m}, 2 \mathrm{H}), 1.45$ (quint, $4 \mathrm{H}, J=6.8 \mathrm{~Hz}), 1.35(\mathrm{~m}, 2 \mathrm{H}), 1.31-1.22(\mathrm{~m}, 12 \mathrm{H}), 0.87(\mathrm{t}, 6 \mathrm{H}, J=6.7$ $\mathrm{Hz}) ;{ }^{13} \mathrm{C} \mathrm{NMR}\left(101 \mathrm{MHz}, \mathrm{CDCl}_{3}\right.$, resolved signals corresponding to the minor diastereoisomer are reported in italics) $\delta 81.8,81.6,78.4,78.0,76.5,76.3,31.3,30.9,30.2,28.9,28.9,28.5,28.5,25.8,25.7$, 22.5, 18.7, 14.0; IR 2956 (m), 2929 (s), $2871(\mathrm{~m}), 2857$ (m), $1581(\mathrm{w}), 1465$ (m), 1444 (w), 1435 (w), 1379 (w), 1367 (w), 1359 (w), 1345 (w), 1330 (w), 1314 (w), 1068 (s), 911 (m), 888 (w); HRMS (ESI) calcd for $\mathrm{C}_{22} \mathrm{H}_{37} \mathrm{O}^{+}[\mathrm{M}+\mathrm{H}]^{+}$317.2839; found 317.2847.

tert-Butyl 2-(non-2-yn-1-yl)pyrrolidine-1-carboxylate (10aa): was prepared from N-Boc-4pentenamine (9a) $(74.5 \mathrm{mg}, 0.400 \mathrm{mmol})$ and octynyl bromide (6a) $(98.0 \mathrm{mg}, 0.521 \mathrm{mmol})$. It was obtained as a pale yellow oil (84.4 mg, $0.288 \mathrm{mmol}, 72 \%$ yield); $\mathrm{R}_{\mathrm{f}} 0.60$ (Hexane/EtOAc 5/1). The product was obtained as a mixture of rotamers. In order to characterize it, it was subjected to deprotection of the amino group according to the general procedure.

2-(Non-2-yn-1-yl)pyrrolidine (10aa'): was obtained as a yellow oil (62.6 mg, $0.324 \mathrm{mmol}$, quantitative); ${ }^{1} \mathrm{H} \mathrm{NMR}\left(400 \mathrm{MHz}, \mathrm{CDCl}_{3}\right) \delta 3.16(\mathrm{dt}, 1 \mathrm{H}, J=13.0,6.5 \mathrm{~Hz}), 3.02(\mathrm{ddd}, 1 \mathrm{H}, J=10.4,7.5,5.6$ Hz), 2.85 (ddd, $J=10.3,7.6,6.7 \mathrm{~Hz}), 2.37-2.25(\mathrm{~m}, 2 \mathrm{H}), 2.14(\mathrm{tt}, 2 \mathrm{H}, J=6.9,2.4 \mathrm{~Hz}), 2.05(\mathrm{~m}, 1 \mathrm{H}, \mathrm{br}$ $\mathrm{s}), 1.86(\mathrm{~m}, 1 \mathrm{H}), 1.81-1.68(\mathrm{~m}, 2 \mathrm{H}), 1.51-1.41(\mathrm{~m}, 3 \mathrm{H}), 1.41-1.20(\mathrm{~m}, 6 \mathrm{H}), 0.88(\mathrm{t}, 3 \mathrm{H}, J=6.8 \mathrm{~Hz})$; ${ }^{13} \mathrm{C}$ NMR $\left(101 \mathrm{MHz}, \mathrm{CDCl}_{3}\right) \delta 81.7,77.3,57.7,46.6,31.3,30.7,29.0,28.5,25.5,25.4,22.6,18.7,14.0$; IR 3332 (br w), 2956 (s), 2928 (s), 2857 (s), 2116 (w), 1748 (w), 1748 (w), 1725 (w), 1725 (w), 1692 (w), $1612(w), 1554(w), 1462(w), 1429(w), 1429(w), 1403(w), 1352(w), 1331(w), 1283(w), 1245$ (w), 1152 (w), 1092 (w), 957 (w), 956 (w), 911 (w), 810 (w); HRMS (ESI) calcd for $\mathrm{C}_{13} \mathrm{H}_{24} \mathrm{~N}^{+}[\mathrm{M}+\mathrm{H}]^{+}$ 194.19033; found 194.19044.

tert-Butyl 2-(6-((tert-butyldiphenylsilyl)oxy)hex-2-yn-1-yl)pyrrolidine-1-carboxylate (10ad): was prepared from N-Boc-4-pentenamine (9a) $(74.5 \mathrm{mg}, 0.400 \mathrm{mmol})$ and alkynyl bromide $\mathbf{6 d}(208 \mathrm{mg}$, $0.519 \mathrm{mmol})$. It was obtained as a pale yellow oil (144 mg, $0.288 \mathrm{mmol}, 72 \%$ yield); $\mathrm{R}_{\mathrm{f}} 0.50$ (Hex- 
ane/EtOAc 5/1). The product was obtained as a mixture of rotamers. In order to characterize it, it was subjected to deprotection of the amino group according to the general procedure.

2-(6-((tert-Butyldiphenylsilyl)oxy)hex-2-yn-1-yl)pyrrolidine (10ad'): was obtained as a yellow oil (117 mg, $0.288 \mathrm{mmol}$, quantitative); ${ }^{1} \mathrm{H} \mathrm{NMR}\left(400 \mathrm{MHz}, \mathrm{CDCl}_{3}\right) \delta 7.73(\mathrm{dd}, 4 \mathrm{H}, J=7.4,1.6 \mathrm{~Hz}), 7.42-$ $7.33(\mathrm{~m}, 6 \mathrm{H}), 3.71(\mathrm{t}, 2 \mathrm{H}, J=5.7 \mathrm{~Hz}), 3.09(\mathrm{ddd}, 1 \mathrm{H}, J=12.8,6.2,6.2 \mathrm{~Hz}), 3.05-2.86(\mathrm{~m}, 2 \mathrm{H}), 2.94$ (ddd, $1 \mathrm{H}, J=10.5,7.5,5.5 \mathrm{~Hz}), 2.76(\mathrm{ddd}, 2 \mathrm{H}, J=10.5,7.0,7.0 \mathrm{~Hz}), 2.34-2.20(\mathrm{~m}, 3 \mathrm{H}), 1.76-1.62$ (m, $2 \mathrm{H}), 1.71$ (quint, $2 \mathrm{H}, J=6.5 \mathrm{~Hz}$ ), 1.41 (dddd, $1 \mathrm{H}, J=12.5,7.5,7.5,7.5 \mathrm{~Hz}), 1.05(\mathrm{~s}, 9 \mathrm{H}) ;{ }^{13} \mathrm{C}$ NMR $\left(101 \mathrm{MHz}, \mathrm{CDCl}_{3}\right) \delta 135.5,133.8,129.6,127.6,83.4,74.0,62.4,58.6,45.9,31.6,29.6,26.8$, 23.3, 22.1, 19.2, 15.2; IR 3341 (w), 3069 (w), 3049 (w), 2953 (m), 2932 (m), 2889 (m), 2888 (m), 2856 (m), 1688 (m), $1591(w), 1468$ (m), 1429 (s), 1393 (w), 1393 (w), 1359 (w), 1359 (w), $1334(w), 1305$ (w), $1304(w), 1259(w), 1238(w), 1204(w), 1204(w), 1191(w), 1191(w), 1145(w), 1111(\mathrm{~s}), 1063$ (m), $1004(\mathrm{w}), 1004(\mathrm{w}), 970(\mathrm{w}), 936(\mathrm{w}), 876(\mathrm{~m}), 876(\mathrm{~m}), 822(\mathrm{~m})$; HRMS (ESI) calcd for $\mathrm{C}_{26} \mathrm{H}_{36} \mathrm{NOSi}^{+}[\mathrm{M}+\mathrm{H}]^{+}$406.2561; found 406.2562.

tert-Butyl 2-(7-phenylhept-2-yn-1-yl)pyrrolidine-1-carboxylate (10ae):was prepared from N-Boc4-pentenamine (9a) (74.5 mg, $0.400 \mathrm{mmol})$ and alkynyl bromide $6 \mathbf{e}(116 \mathrm{mg}, 0.520 \mathrm{mmol})$. It was obtained as a pale yellow oil (101 mg, $0.308 \mathrm{mmol}, 77 \%$ yield); $\mathrm{R}_{\mathrm{f}} 0.52$ (Hexane/EtOAc 5/1). The product was obtained as a mixture of rotamers. In order to characterize it, it was subjected to deprotection of the amino group according to the general procedure.

2-(6-Phenylhex-2-yn-1-yl)pyrrolidine (10ae'): was obtained as a yellow oil (52.3 mg, $0.230 \mathrm{mmol}$, 74\% yield); ${ }^{1} \mathrm{H}$ NMR (400 MHz, $\left.\mathrm{CDCl}_{3}\right) \delta 7.31(\mathrm{~m}, 2 \mathrm{H}), 7.23-7.18(\mathrm{~m}, 3 \mathrm{H}), 3.80$ (br s, $\left.1 \mathrm{H}\right), 3.28$ (ddd, $1 \mathrm{H}, J=13.3,7.0,6.4 \mathrm{~Hz}), 3.10(\mathrm{ddd}, 1 \mathrm{H}, J=10.5,7.5,5.8 \mathrm{~Hz}), 2.95$ (ddd,1 H, $J=10.6,7.9,6.7$ Hz), $2.73(\mathrm{t}, 2 \mathrm{H}, J=7.5 \mathrm{~Hz}), 2.44-2.39(\mathrm{~m}, 2 \mathrm{H}), 2.20(\mathrm{tt}, 2 \mathrm{H}, J=7.0,2.3 \mathrm{~Hz}), 1.96(\mathrm{~m}, 1 \mathrm{H}), 1.90-$ $1.74(\mathrm{~m}, 4 \mathrm{H}), 1.83$ (quint, $2 \mathrm{H}, J=6.9 \mathrm{~Hz}), 1.56(\mathrm{~m}, 1 \mathrm{H}) ;{ }^{13} \mathrm{C} \mathrm{NMR}\left(101 \mathrm{MHz}, \mathrm{CDCl}_{3}\right) \delta 141.7,128.4$, $128.3,125.8,81.5,77.4,57.8,46.4,34.8,30.6,30.6,25.2,24.9,18.2$; IR $3087(w), 3078(w), 3063(w)$, 3062 (w), 3026 (w), 3008 (w), 2995 (w), 2939 (s), 2932 (s), 2861 (m), 2860 (m), $2112(\mathrm{w}), 2111(\mathrm{w})$, 
$2108(w), 2107(w), 2091(w), 2090(w), 2089(w), 1950(w), 1949(w), 1944(w), 1943(w), 1687(s)$, $1635(\mathrm{w}), 1603$ (w), $1496(\mathrm{~m}), 1455$ (s), $1430(\mathrm{~m}), 1408$ (m), $1353(\mathrm{w}), 1352(\mathrm{w}), 1334(\mathrm{w}), 1294(\mathrm{w})$, $1229(w), 1201$ (s), 1176 (s), 1175 (s), 1130 (m), $1101(w), 1090(w), 1089$ (w), 1082 (w), 1057 (w), $1050(w), 1032(w), 965(w), 954(w), 943(w), 911(\mathrm{~m}), 882(w), 881(w), 861(w), 827(\mathrm{~m}), 814(w)$; HRMS (ESI) calcd for $\mathrm{C}_{16} \mathrm{H}_{22} \mathrm{~N}^{+}[\mathrm{M}+\mathrm{H}]^{+} 228.1747$; found 228.1749.

tert-Butyl 2-(4-(benzyloxy)-4-methylpent-2-yn-1-yl)pyrrolidine-1-carboxylate (10ah): was prepared from N-Boc-4-pentenamine (9a) $(74.5 \mathrm{mg}, 0.400 \mathrm{mmol})$ and alkynyl bromide 6k (132 mg, 0.520 mmol). It was obtained as a pale yellow oil (106 mg, $0.298 \mathrm{mmol}, 74 \%$ yield, mixture of rotamers); $R_{\mathrm{f}}$ 0.64 (Hexane/EtOAc 5/1); ${ }^{1} \mathrm{H}$ NMR (400 MHz, $\left.\mathrm{CDCl}_{3}\right) \delta$ 7.39-7.29 (m, $\left.3 \mathrm{H}\right), 7.25$ (m, $\left.2 \mathrm{H}\right), 4.60$ (s, 2 H), 3.94 (m, $1 \mathrm{H}), 3.82$ (m, $1 \mathrm{H}), 3.49-3.29$ (m, $2 \mathrm{H}), 2.66(\mathrm{~m}, 1 \mathrm{H}), 2.57$ (m, $1 \mathrm{H}), 2.45$ (m, $1 \mathrm{H}), 2.09$ $1.86(\mathrm{~m}, 3 \mathrm{H}), 1.79(\mathrm{~m}, 1 \mathrm{H}), 1.51(\mathrm{~s}, 6 \mathrm{H}), 1.47(\mathrm{~s}, 9 \mathrm{H}), 1.46(\mathrm{~m}, 9 \mathrm{H}) ;{ }^{13} \mathrm{C} \mathrm{NMR}\left(101 \mathrm{MHz}, \mathrm{CDCl}_{3}\right.$; the signals of resolved rotamers are reported in italics) $\delta 154.3,154.2,139.2,128.2,127.6,127.2,84.0$, $83.6,81.9,81.5,79.3,79.1,70.7,66.3,56.2,56.1,47.1,46.7,30.7,29.9,29.1,28.5,24.2,23.6,23.4$, 22.9; IR 2979 (w), 2933 (w), 2932 (w), 2931 (w), 2926 (w), 2911 (w), 2910 (w), 2909 (w), 2881 (w), $2880(w), 2879(w), 1733(w), 1696(s), 1656(w), 1655(w), 1654(w), 1571(w), 1571(w), 1570(w)$, $1554(\mathrm{w}), 1553(\mathrm{w}), 1512(\mathrm{w}), 1455(\mathrm{w}), 1455(\mathrm{w}), 1396(\mathrm{~s}), 1364(\mathrm{w}), 1341(\mathrm{w}), 1281(\mathrm{w}), 1280(\mathrm{w})$, $1252(w), 1251(w), 1241(w), 1240(w), 1164(\mathrm{~m}), 1163(\mathrm{~m}), 1120(\mathrm{w}), 1096(w), 1057(w), 960(w)$, 929 (w), 905 (w), $813(w)$; HRMS (ESI) calcd for $\mathrm{C}_{22} \mathrm{H}_{32} \mathrm{NO}_{3}\left[\mathrm{M}^{+}\right]$358.2382; found 358.2374.

tert-Butyl 2-(4-(benzyloxy)dec-2-yn-1-yl)pyrrolidine-1-carboxylate (10aj): was prepared from NBoc-4-pentenamine (9a) $(74.5 \mathrm{mg}, 0.400 \mathrm{mmol})$ and alkynyl bromide $\mathbf{6 j}$ (161 $\mathrm{mg}, 0.520 \mathrm{mmol})$. It was obtained as a pale yellow oil (104 mg, $0.251 \mathrm{mmol}, 63 \%$ yield); $\mathrm{R}_{\mathrm{f}} 0.54$ (Hexane/EtOAc 5/1). The product was obtained as a mixture of rotamers. In order to characterize it, it was subjected to deprotection of the amino group according to the general procedure.

(4-(Benzyloxy)dec-2-yn-1-yl)pyrrolidine (10aj'): was obtained as a dark yellow oil (76.6 mg, 0.244 mmol, 97\% yield); ${ }^{1} \mathrm{H}$ NMR (400 $\left.\mathrm{MHz} \mathrm{CDCl}_{3}\right) \delta$ 7.41-7.30 (m, $\left.4 \mathrm{H}\right), 7.28(\mathrm{~m}, 1 \mathrm{H}), 4.77(\mathrm{~d}, 1 \mathrm{H}, J=$ 
$11.8 \mathrm{~Hz}), 4.49(\mathrm{~d}, 1 \mathrm{H}, J=11.8 \mathrm{~Hz}), 4.07(\mathrm{tt}, 1 \mathrm{H}, J=6.5,1.8 \mathrm{~Hz}), 3.23(\mathrm{ddd}, 1 \mathrm{H}, J=13.1,6.5,6.5$ Hz), 3.03 (m, $1 \mathrm{H}), 2.88$ (ddd, $1 \mathrm{H}, J=10.3,7.2,7.2 \mathrm{~Hz}), 2.42(\mathrm{dd}, 2 \mathrm{H}, J=6.1,1.8 \mathrm{~Hz}), 1.97-1.86$ (m, $2 \mathrm{H}), 1.85-1.61(\mathrm{~m}, 3 \mathrm{H}), 1.56-1.37(\mathrm{~m}, 3 \mathrm{H}), 1.35-1.21(\mathrm{~m}, 6 \mathrm{H}), 0.87(\mathrm{t}, 3 \mathrm{H}, J=6.5 \mathrm{~Hz}) ;{ }^{13} \mathrm{C} \mathrm{NMR}$ $\left(101 \mathrm{MHz} \mathrm{CDCl}_{3}\right) \delta 139.9,128.3,127.9,127.6,81.1,77.0,70.4,69.0,57.6,46.3,36.0,31.8,30.6,29.0$, 25.4, 25.1, 24.8, 22.6, 14.1; IR 3395 (br w), 3032 (w), 2953 (s), 2928 (s), 2857 (s), 1737 (m), 1715 (w), $1690(\mathrm{~m}), 1679(\mathrm{~m}), 1642(\mathrm{~m}), 1543(\mathrm{w}), 1497(\mathrm{w}), 1456(\mathrm{~m}), 1435(\mathrm{w}), 1385(\mathrm{w}), 1380(\mathrm{w}), 1337(\mathrm{w})$, $1313(w), 1287(w), 1286(w), 1236(w), 1209(w), 1209(w), 1169(w), 1154(w), 1154(w), 1089(s)$, 1070 (s), 1029 (m), 919 (w), 912 (w), 822 (w); HRMS (ESI) calcd for $\mathrm{C}_{21} \mathrm{H}_{32} \mathrm{NO}^{+}[\mathrm{M}+\mathrm{H}]^{+} 314.2478$; found 314.2486 .

tert-Butyl 2-(non-2-yn-1-yl)-5-phenylpyrrolidine-1-carboxylate (10ba): was prepared from N-Boc amine 9b (105 mg, $0.402 \mathrm{mmol})$ and octynyl bromide $(\mathbf{6 a})(98.0 \mathrm{mg}, 0.521 \mathrm{mmol})$. It was obtained as a pale yellow oil (110 mg, $0.298 \mathrm{mmol}, 74 \%$ yield); $\mathrm{R}_{\mathrm{f}} 0.60$ (Hexane/EtOAc 5/1). The product was obtained as a mixture of rotamers. In order to characterize it, it was subjected to deprotection of the amino group according to the general procedure.

2-(Non-2-yn-1-yl)-5-phenylpyrrolidine (10ba'): was obtained as a dark yellow oil (76.6 mg, 0.244 mmol, 97\% yield; mixture of inseparable diastereoisomers, d.r. trans/cis 10/90). ${ }^{34} \mathrm{H}$ NMR (400 MHz, $\left.\mathrm{CDCl}_{3}\right) \delta 7.40(\mathrm{~m}, 2 \mathrm{H}), 7.31(\mathrm{~m}, 2 \mathrm{H}), 7.23(\mathrm{~m}, 2 \mathrm{H}), 4.17(\mathrm{dd}, J=7.4,7.4 \mathrm{~Hz}), 3.36(\mathrm{ddd}, J=13.2$, 6.1, 6.1 Hz), 2.45 (dddd, $1 \mathrm{H}, J=16.4,5.8,2.3,2.3 \mathrm{~Hz}), 2.38(\mathrm{~m}, 1 \mathrm{H}), 2.20-2.11(\mathrm{~m}, 3 \mathrm{H}), 1.98(\mathrm{~m}, 1$ H), 1.79-1.63 (m, $2 \mathrm{H}), 1.48$ (quint, $2 \mathrm{H}, J=7.0 \mathrm{~Hz}), 1.43-1.32(\mathrm{~m}, 2 \mathrm{H}), 1.33-1.22(\mathrm{~m}, 4 \mathrm{H}), 0.88(\mathrm{t}, J=$ $7.0 \mathrm{~Hz}) ;{ }^{13} \mathrm{C} \mathrm{NMR}\left(101 \mathrm{MHz}, \mathrm{CDCl}_{3}\right) \delta 144.7,128.2,126.7,126.6,81.7,77.6,62.7,57.9,34.2,31.3$, 30.7, 29.0, 28.5, 26.0, 22.5, 18.7, 14.0; IR 3063 (w), 3028 (w), 2955 (m), 2924 (s), 2853 (s), 1738 (w), $1603(w), 1492(w), 1458(\mathrm{~m}), 1434(w), 1400(w), 1399(w), 1377(w), 1250(w), 1109(w), 1075(w)$, 1028 (w), 910 (s), 828 (w); HRMS (ESI) calcd for $\mathrm{C}_{19} \mathrm{H}_{28} \mathrm{~N}^{+}[\mathrm{M}+\mathrm{H}]^{+}$270.2216; found 270.2225.

tert-Butyl 2-heptyl-5-(non-2-yn-1-yl)pyrrolidine-1-carboxylate (10ca): was prepared from N-Boc amine 9c (108 mg, $0.400 \mathrm{mmol})$ and octynyl bromide (6a) $(98.3 \mathrm{mg}, 0.520 \mathrm{mmol})$. It was obtained as a 
pale yellow oil (77.0 mg, $0.204 \mathrm{mmol}, 51 \%$ yield); $\mathrm{R}_{\mathrm{f}} 0.89$ (Hexane/EtOAc 5/1). The product was obtained as a mixture of rotamers. In order to characterize it, it was subjected to deprotection of the amino group according to the general procedure.

2-Heptyl-5-(non-2-yn-1-yl)pyrrolidine (10ca'): was obtained as a dark yellow oil (52.3 mg, 0.188 mmol, 94\% yield; mixture of inseparable diastereoisomers, d.r. trans/cis > 3/97) ${ }^{35}{ }^{1} \mathrm{H} \mathrm{NMR}(400 \mathrm{MHz}$, $\left.\mathrm{CDCl}_{3}\right) \delta 3.13(\mathrm{dddd}, 1 \mathrm{H}, \quad J=7.5,6.0,6.0,6.0 \mathrm{~Hz}), 2.97(\mathrm{dddd}, J=8.0,6.5,6.5,6.5 \mathrm{~Hz}), 2.32(\mathrm{~m}, 2$ H), $2.13(\mathrm{tt}, 2 \mathrm{H}, J=6.9,2.3 \mathrm{~Hz}), 1.88-1.77(\mathrm{~m}, 3 \mathrm{H}), 1.53-1.42(\mathrm{~m}, 5 \mathrm{H}), 1.41-1.21(\mathrm{~m}, 14 \mathrm{H}), 0.91-$ $0.83(\mathrm{~m}, 6 \mathrm{H}) ;{ }^{13} \mathrm{C}$ NMR $\left(101 \mathrm{MHz}, \mathrm{CDCl}_{3}\right) \delta 81.8,77.3,59.6,57.7,36.7,31.8,31.7,31.4,30.3,29.5$, 29.0, 28.5, 27.4, 25.5, 22.6, 22.6, 18.7, 14.1, 14.0; IR 2957 (m), 2927 (m), 2856 (m), $2184(\mathrm{w}), 2183$ (w), $1464(w), 1434(w), 1433(w), 1404(w), 1403(w), 1379(w), 1127(w), 1122(w), 1100(w), 1084$ (w), $991(w), 990(w), 962(w), 909(s), 879(w) .1032(w), 965(w), 954(w), 943(w), 911(m), 882(w)$, $881(\mathrm{w}), 861(\mathrm{w}), 827(\mathrm{~m}), 814(\mathrm{w})$; HRMS (ESI) calcd for $\mathrm{C}_{19} \mathrm{H}_{36} \mathrm{~N}^{+}[\mathrm{M}+\mathrm{H}]^{+}$278.2842; found 278.2846.

tert-Butyl 2-(but-3-en-1-yl)-5-(non-2-yn-1-yl)pyrrolidine-1-carboxylate (10da): was prepared from N-Boc amine 9d (95.0 mg, $0.397 \mathrm{mmol})$ and octynyl bromide (6a) $(98.0 \mathrm{mg}, 0.521 \mathrm{mmol})$. It was obtained as a pale yellow oil (83.4 mg, $0.240 \mathrm{mmol}, 60 \%$ yield); $\mathrm{R}_{\mathrm{f}} 0.58$ (Hexane/EtOAc 5/1). The product was obtained as a mixture of rotamers. In order to characterize it, it was subjected to deprotection of the amino group according to the general procedure.

2-(But-3-en-1-yl)-5-(non-2-yn-1-yl)pyrrolidine (10da'): was obtained as a dark yellow oil (59.1 mg, 0.239 mmol, $99 \%$ yield; mixture of inseparable diastereoisomers, d.r. trans/cis 5/95); ${ }^{36}{ }^{1} \mathrm{H}$ NMR (400 $\left.\mathrm{MHz}, \mathrm{CDCl}_{3}\right) \delta 5.81(\mathrm{~m}, 1 \mathrm{H}), 5.00(\mathrm{dddd}, 1 \mathrm{H}, J=17.1,6.5,2.0,2.0 \mathrm{~Hz}), 4.92(\mathrm{~m}, 1 \mathrm{H}), 3.14(\mathrm{ddd}, 1$ $\mathrm{H}, J=18.6,6.0,6.0 \mathrm{~Hz}), 3.00(\mathrm{ddd}, 1 \mathrm{H}, J=19.6,5.5,5.5 \mathrm{~Hz}), 2.35$ (dddd, $1 \mathrm{H}, J=16.1,8.0,2.5,2.5$ Hz), 2.27 (m, $1 \mathrm{H}), 2.18-2.03$ (m, $4 \mathrm{H}), 1.96$ (br s, $1 \mathrm{H}), 1.90-1.76$ (m, $2 \mathrm{H}), 1.59$ (dddd, $1 \mathrm{H}, J=13.6$, 8.5, 7.0, 7.0 Hz), 1.55-1.40 (m, $4 \mathrm{H}), 1.40-1.20(\mathrm{~m}, 7 \mathrm{H}), 0.86(\mathrm{t}, 3 \mathrm{H}, J=6.2 \mathrm{~Hz}) ;{ }^{13} \mathrm{C} \mathrm{NMR}(101 \mathrm{MHz}$, $\left.\mathrm{CDCl}_{3}\right) \delta 138.6,114.3,81.7,77.3,58.9,57.7,35.7,31.6,31.5,31.3,30.2,29.0,28.5,25.6,22.5,18.7$, 
14.0; IR 3076 (w), 2956 (m), 2928 (s), 2857 (m), 1714 (w), 1698 (w), 1682 (w), 1661 (w), 1641 (w), $1457(w), 1435(w), 1406(w), 1379(w), 1278(w), 1177(w), 1135(w), 1115(w), 995(w), 910(s)$; HRMS (ESI) calcd for $\mathrm{C}_{17} \mathrm{H}_{30} \mathrm{~N}^{+}[\mathrm{M}+\mathrm{H}]^{+}$248.2373; found 248.2371.

\section{tert-Butyl 2-(non-2-yn-1-yl)hexahydrocyclopenta[b]pyrrole-1(2H)-carboxylate (10ea): was pre-} pared from N-Boc amine $9 e(90.1 \mathrm{mg}, 0.400 \mathrm{mmol})$ and octynyl bromide (6a) $(98.0 \mathrm{mg}, 0.521 \mathrm{mmol})$. It was obtained as a pale yellow oil $\left(98.5 \mathrm{mg}, 0.295 \mathrm{mmol}, 74 \%\right.$ yield); $\mathrm{R}_{\mathrm{f}} 0.55$ (Hexane/EtOAc $\left.5 / 1\right)$. The product was obtained as a mixture of rotamers. In order to characterize it, it was subjected to deprotection of the amino group according to the general procedure.

2-(Non-2-yn-1-yl)octahydrocyclopenta[b]pyrrole (10ea'): was obtained as a dark yellow oil (61.2 mg, 0.263 mmol, $89 \%$ yield; mixture of inseparable diastereoisomers, d.r. trans/cis > 5/95); ${ }^{1} \mathrm{H}$ NMR $\left(400 \mathrm{MHz}, \mathrm{CDCl}_{3}\right) \delta 3.62(\mathrm{dd}, 1 \mathrm{H}, J=7.1,7.1 \mathrm{~Hz}), 2.98(\mathrm{ddd}, 1 \mathrm{H}, J=16.2,5.4,5.4 \mathrm{~Hz}), 2.54$ (dddd, $J$ $=17.1,8.0,8.0,2.5 \mathrm{~Hz}), 2.38(\mathrm{dddd}, 1 \mathrm{H}, J=16.4,5.0,2.4,2.4 \mathrm{~Hz}), 2.28(\mathrm{dddd}, 1 \mathrm{H}, J=16.4,4.9,2.3$, $2.3 \mathrm{~Hz}$ ), 2.13 (tt, $2 \mathrm{H}, J=6.9,2.3 \mathrm{~Hz}), 2.05$ (ddd, $1 \mathrm{H}, J=12.2,8.9,5.2 \mathrm{~Hz}), 1.86$ (br s, $1 \mathrm{H}), 1.68-1.48$ (m, $6 \mathrm{H}), 1.46$ (quint, $2 \mathrm{H}, J=7.0 \mathrm{~Hz}), 1.36(\mathrm{dt}, 2 \mathrm{H}, J=16.1,7.0 \mathrm{~Hz}), 1.31-1.21(\mathrm{~m}, 6 \mathrm{H}), 1.01$ (ddd, 1 $\mathrm{H}, J=11.8,10.8,8.9 \mathrm{~Hz}), 0.88(\mathrm{t}, 3 \mathrm{H}, J=6.7 \mathrm{~Hz}) ;{ }^{13} \mathrm{C} \mathrm{NMR}\left(101 \mathrm{MHz}, \mathrm{CDCl}_{3}\right) \delta 82.0,77.0,63.5$, 58.8, 43.1, 39.8, 34.2, 33.1, 31.3, 29.0, 28.6, 24.1, 23.7, 22.5, 18.7, 14.0; IR 3344 (br w), 2951 (s), 2950 (s), 2930 (s), 2858 (s), $1696(w), 1695(w), 1694(w), 1693(w), 1692(w), 1689(w), 1683(w), 1682$ (w), $1641(\mathrm{w}), 1640(\mathrm{w}), 1465(\mathrm{~m}), 1451(\mathrm{~m}), 1434(\mathrm{~m}), 1402(\mathrm{w}), 1379(\mathrm{w}), 1359(\mathrm{w}), 1348(\mathrm{w}), 1326$ (w), $1298(w), 1286(w), 1277(w), 1221(w), 1179(w), 1165(w), 1126(w), 1112(w), 1091(w), 1072$ (w), $1046(\mathrm{w}), 1045(\mathrm{w}), 993(\mathrm{w}), 977(\mathrm{w}), 931(\mathrm{w}), 930(\mathrm{w}), 909(\mathrm{~m}), 891(\mathrm{w}), 890(\mathrm{w}), 840(\mathrm{w})$; HRMS (ESI) calcd for $\mathrm{C}_{16} \mathrm{H}_{28} \mathrm{~N}^{+}[\mathrm{M}+\mathrm{H}]^{+}$234.2216; found 234.2218.

tert-Butyl 2-(non-2-yn-1-yl)octahydro-1H-indole-1-carboxylate (10fa): was prepared from N-Boc amine $9 \mathbf{f}$ (96.0 mg, $0.401 \mathrm{mmol})$ and octynyl bromide (6a) $(98.0 \mathrm{mg}, 0.521 \mathrm{mmol})$. It was obtained as a pale yellow oil (88.3 mg, $0.254 \mathrm{mmol}, 64 \%$ yield); $\mathrm{R}_{\mathrm{f}} 0.60$ (Hexane/EtOAc 5/1). The product was ob- 
tained as a mixture of rotamers. In order to characterize it, it was subjected to deprotection of the amino group according to the general procedure.

2-(Non-2-yn-1-yl)octahydro-1H-indole (10fa'): was obtained as a yellow oil $(61.7 \mathrm{mg}, 0.249 \mathrm{mmol}$, $98 \%$ yield; mixture of inseparable diastereoisomers, d.r. trans/cis 6/94); $\left.{ }^{37}{ }^{1} \mathrm{H} \mathrm{NMR} \mathrm{(400} \mathrm{MHz,} \mathrm{CDCl}_{3}\right) \delta$ 3.25 (dddd, $1 \mathrm{H}, J=8.0,8.0,6.0,6.0 \mathrm{~Hz}), 3.05$ (dd, $1 \mathrm{H}, J=10.8,5.4 \mathrm{~Hz}), 2.43$ (dddd, $1 \mathrm{H}, J=16.1$, 5.0, 2.5, $2.5 \mathrm{~Hz}$ ), 2.37 (dddd, $1 \mathrm{H}, J=16.1,4.5,2.0,2.0 \mathrm{~Hz}), 2.16(\mathrm{tt}, 2 \mathrm{H}, J=6.9,2.3 \mathrm{~Hz}), 2.04(\mathrm{~m}, 1$ H), $1.93(\mathrm{~m}, 1 \mathrm{H}), 1.78(\mathrm{~s}, 1 \mathrm{H}), 1.65(\mathrm{~m}, 2 \mathrm{H}), 1.57-1.42(\mathrm{~m}, 6 \mathrm{H}), 1.42-1.20(\mathrm{~m}, 9 \mathrm{H}), 0.88(\mathrm{t}, 3 \mathrm{H}, J=$ $6.8 \mathrm{~Hz}) ;{ }^{13} \mathrm{C} \mathrm{NMR}\left(101 \mathrm{MHz}, \mathrm{CDCl}_{3}\right) \delta 81.8,77.5,57.8,56.9,38.3,36.6,31.3,29.1,29.0,28.6,28.6$, 26.3, 23.9, 22.5, 22.0, 18.8, 14.0; IR 2926 (s), 2854 (m), $1451(w), 1403(w), 1377(w), 1377(w), 1347$ (w), $1347(w), 1332(w), 1332(w), 1285(w), 1285(w), 1284(w), 1284(w), 1216(w), 1083(w), 1083$ (w), $1028(w), 1028(w), 910(w), 818(w)$; HRMS (ESI) calcd for $\mathrm{C}_{17} \mathrm{H}_{30} \mathrm{~N}^{+}[\mathrm{M}+\mathrm{H}]^{+}$248.2373; found 248.2369.

tert-Butyl 2-(10-bromodec-2-yn-1-yl)octahydro-1H-indole-1-carboxylate (10fi): was prepared from N-Boc amine 9f $(96.0 \mathrm{mg}, 0.401 \mathrm{mmol})$ and alkynyl bromide 6i (147 $\mathrm{mg}, 0.520 \mathrm{mmol})$. It was obtained as a pale yellow oil (112 $\mathrm{mg}, 0.253 \mathrm{mmol}, 63 \%$ yield, mixture of inseparable diastereoisomers, d.r. trans/cis < 5/95); $\mathrm{R}_{\mathrm{f}} 0.69$ (Hexane/EtOAc 5/1). The product was obtained as a mixture of rotamers. In order to characterize it, NMR spectra were acquired at $55{ }^{\circ} \mathrm{C}:{ }^{1} \mathrm{H} \mathrm{NMR}\left(400 \mathrm{MHz}, \mathrm{CDCl}_{3}\right) \delta 3.83-$ $3.68(\mathrm{~m}, 2 \mathrm{H}), 3.39(\mathrm{t}, J=6.8 \mathrm{~Hz}), 2.76(\mathrm{~m}, 1 \mathrm{H}), 2.46(\mathrm{dddd}, J=16.1,7.7,2.3,2.3 \mathrm{~Hz}), 2.25-2.10(\mathrm{~m}, 3$ H), 2.03-1.91 (m, $3 \mathrm{H}), 1.87$ (quint, $2 \mathrm{H}, \mathrm{J}=6.9 \mathrm{~Hz}), 1.73(\mathrm{~m}, 1 \mathrm{H}), 1.69-1.58(\mathrm{~m}, 3 \mathrm{H}), 1.56-1.24(\mathrm{~m}$, $13 \mathrm{H}), 1.46$ (s, $9 \mathrm{H}), 1.17(\mathrm{tt}, 1 \mathrm{H}, J=13.1,3.0 \mathrm{~Hz}) ;{ }^{13} \mathrm{C} \mathrm{NMR}\left(101 \mathrm{MHz}, \mathrm{CDCl}_{3}\right) \delta 154.5,81.9,78.9$, 77.5, 58.1, 57.0, 36.0, 33.8, 33.3, 32.9, 29.2, 28.9, 28.6, 28.3, 28.1, 26.3, 25.7, 25.3, 24.2, 20.9, 18.8; IR $2929(\mathrm{~m}), 2856(\mathrm{w}), 1690(\mathrm{~s}), 1454(\mathrm{w}), 1394(\mathrm{~s}), 1363(\mathrm{~m}), 1295(\mathrm{w}), 1251(\mathrm{w}), 1164(\mathrm{~m}), 1116(\mathrm{~m})$, 1096 (w), 971 (w), 907 (w), 863 (w), 862 (w); HRMS (ESI) calcd for $\mathrm{C}_{23}{ }^{79} \mathrm{BrH}_{39} \mathrm{NO}_{2}{ }^{+}[\mathrm{M}+\mathrm{H}]^{+}$ 440.2159; found 440.2166. 
tert-Butyl 2-(non-2-yn-1-yl)octahydrocyclohepta[b]pyrrole-1(2H)-carboxylate (10ga): was prepared from N-Boc amine $9 \mathrm{~g}(101 \mathrm{mg}, 0.399 \mathrm{mmol})$ and octynyl bromide (6a) $(98.0 \mathrm{mg}, 0.521 \mathrm{mmol})$. It was obtained as a pale yellow oil $\left(82.3 \mathrm{mg}, 0.227 \mathrm{mmol}, 57 \%\right.$ yield); $\mathrm{R}_{\mathrm{f}} 0.60$ (Hexane/EtOAc 5/1). The product was obtained as a mixture of rotamers. In order to characterize it, it was subjected to deprotection of the amino group according to the general procedure.

2-(Non-2-yn-1-yl)decahydrocyclohepta[b]pyrrole (10ga'): was obtained as a dark yellow oil (53.4 mg, 0.204 mmol, 90\% yield; mixture of inseparable diastereoisomers, d.r. trans/cis > 10/90); ${ }^{38} \mathrm{H}$ NMR $\left(400 \mathrm{MHz}, \mathrm{CDCl}_{3}\right) \delta 4.86($ br s, $1 \mathrm{H}), 3.41(\mathrm{ddd}, 1 \mathrm{H}, J=11.6,9.5,4.0 \mathrm{~Hz}), 3.20$ (ddd, $J=11.4,11.4$, $6.0 \mathrm{~Hz}), 2.42(\mathrm{dt}, 2 \mathrm{H}, J=5.9,2.4 \mathrm{~Hz}), 2.33(\mathrm{~m}, 1 \mathrm{H}), 2.15(\mathrm{~m}, 1 \mathrm{H}), 2.11(\mathrm{tt}, J=6.7,2.2 \mathrm{~Hz}, 2 \mathrm{H}), 1.89$ (m, $1 \mathrm{H}), 1.84-1.75(\mathrm{~m}, 2 \mathrm{H}), 1.63(\mathrm{~m}, 1 \mathrm{H}), 1.55(\mathrm{dd}, 1 \mathrm{H}, J=23.1,11.1 \mathrm{~Hz}), 1.45$ (m, $2 \mathrm{H}), 1.39-1.11$ $(\mathrm{m}, 11 \mathrm{H}), 0.87(t, 3 \mathrm{H}, J=6.8 \mathrm{~Hz}) ;{ }^{13} \mathrm{C} \mathrm{NMR}\left(101 \mathrm{MHz}, \mathrm{CDCl}_{3}\right) \delta$ 82.6, 75.8, 63.0, 57.9, 42.8, 39.7, 31.5, 31.4, 31.3, 31.1, 29.2, 28.9, 28.5, 26.4, 23.2, 22.5, 18.7, 14.0; IR $2921(\mathrm{~m}), 2854(\mathrm{w}), 2853(\mathrm{w})$, $2246(\mathrm{w}), 1680(\mathrm{~m}), 1457(\mathrm{w}), 1445(\mathrm{w}), 1431(\mathrm{w}), 1430(\mathrm{w}), 1380(\mathrm{w}), 1202(\mathrm{~m}), 1183(\mathrm{~m}), 1182(\mathrm{~m})$, 1139 (m), 1036 (w), 1028 (w), 1016 (w), 1008 (w), 998 (w), 909 (s), 835 (w); HRMS (ESI) calcd for $\mathrm{C}_{18} \mathrm{H}_{32} \mathrm{~N}^{+}[\mathrm{M}+\mathrm{H}]^{+}$262.2529; found 262.2519.

tert-Butyl 2-(non-2-yn-1-yl)indoline-1-carboxylate (10ha): was prepared from $N$-Boc aniline 9h (93.3 $\mathrm{mg}, 0.400 \mathrm{mmol})$ and octynyl bromide (6a) $(98.0 \mathrm{mg}, 0.521 \mathrm{mmol})$. It was obtained as a pale yellow oil (109 mg, $0.319 \mathrm{mmol}, 80 \%$ yield); $\mathrm{R}_{\mathrm{f}} 0.55$ (Hexane/EtOAc 5/1). The product was obtained as a mixture of rotamers. In order to characterize it, it was subjected to deprotection of the amino group according to the general procedure.

2-(Non-2-yn-1-yl)indoline (10ha'): was obtained as an orange oil (74.7 mg, $0.309 \mathrm{mmol}, 90 \%$ yield); ${ }^{1} \mathrm{H}$ NMR $\left(400 \mathrm{MHz}, \mathrm{CDCl}_{3}\right) \delta 7.07(\mathrm{~d}, 1 \mathrm{H}, J=7.3 \mathrm{~Hz}), 7.01(\mathrm{td}, 1 \mathrm{H}, J=7.6,0.5 \mathrm{~Hz}), 6.69(\mathrm{~m}, 1 \mathrm{H})$, $6.62(\mathrm{~d}, 1 \mathrm{H}, J=7.8 \mathrm{~Hz}), 4.10$ (br s, $1 \mathrm{H}), 3.95$ (ddd, $1 \mathrm{H}, J=13.4,8.6,6.2 \mathrm{~Hz}), 3.17$ (dd, $1 \mathrm{H}, J=15.7$, 8.7 Hz), $2.75(\mathrm{dd}, 1 \mathrm{H}, J=15.7,6.1 \mathrm{~Hz}), 2.38(\mathrm{dd}, 1 \mathrm{H}, J=4.8,2.4 \mathrm{~Hz}), 2.35(\mathrm{dd}, 1 \mathrm{H}, J=3.8,2.4 \mathrm{~Hz})$, $2.16(\mathrm{tt}, 2 \mathrm{H}, J=6.9,2.3 \mathrm{~Hz}), 1.49$ (quint, $2 \mathrm{H}), 1.44-1.20(\mathrm{~m}, 6 \mathrm{H}), 0.90(\mathrm{t}, 3 \mathrm{H}, J=6.7 \mathrm{~Hz}) ;{ }^{13} \mathrm{C} \mathrm{NMR}$ 
$\left(101 \mathrm{MHz} \mathrm{CDCl}_{3}\right) \delta 150.2,128.0,127.3,124.8,118.6,109.2,82.2,77.0,58.6,35.5,31.3,28.9,28.5$, 26.3, 22.5, 18.7, 14.0; IR 3372 (w), 2954 (w), 2929 (m), 2856 (w), 1731 (w), 1692 (m), 1610 (m), 1591 (w), $1514(\mathrm{~m}), 1485(\mathrm{~m}), 1466(\mathrm{~m}), 1455(\mathrm{~m}), 1411(\mathrm{w}), 1366(\mathrm{w}), 1322(\mathrm{w}), 1301(\mathrm{w}), 1245(\mathrm{~s}), 1158$ (s), 1119 (w), 1049 (w), 1023 (w), 918 (w), 898 (w), 879 (w), 842 (w); HRMS (ESI) calcd for $\mathrm{C}_{17} \mathrm{H}_{24} \mathrm{~N}^{+}$ $[\mathrm{M}+\mathrm{H}]^{+}$242.1903; found 242.1901.

2-(Non-2-yn-1-yl)-1-phenylpyrrolidine (10ia): was prepared from N-phenyl amine 9i (64.5 mg, $0.400 \mathrm{mmol})$ and octynyl bromide $(\mathbf{6 a})(97.8 \mathrm{mg}, 0.520 \mathrm{mmol})$. It was obtained as a pale yellow oil (85.3 mg, $0.317 \mathrm{mmol}, 79 \%$ yield). $\mathrm{R}_{\mathrm{f}} 0.55$ (Hexane/EtOAc 10/1); ${ }^{1} \mathrm{H}$ NMR $\left(400 \mathrm{MHz}, \mathrm{CDCl}_{3}\right) \delta 7.21$ $(\mathrm{dd}, 2 \mathrm{H}, J=8.4,7.4 \mathrm{~Hz}), 6.67(\mathrm{t}, 1 \mathrm{H}, J=7.3 \mathrm{~Hz}), 6.60(\mathrm{~d}, 2 \mathrm{H}, J=8.1 \mathrm{~Hz}), 3.86(\mathrm{~m}, 1 \mathrm{H}), 3.43$ (m, 1 H), $3.17(\mathrm{~m}, 1 \mathrm{H}), 2.58(\mathrm{dd}, 1 \mathrm{H}, J=16.4,2.3 \mathrm{~Hz}), 2.17(\mathrm{tt}, 2 \mathrm{H}, J=6.9,2.3 \mathrm{~Hz}), 2.14-1.95(\mathrm{~m}, 5 \mathrm{H})$, $1.49(\mathrm{q}, 2 \mathrm{H}, J=6.8 \mathrm{~Hz}), 1.40(\mathrm{~m}, 2 \mathrm{H}), 1.35-1.24(\mathrm{~m}, 4 \mathrm{H}), 0.90(\mathrm{t}, 3 \mathrm{H}, J=6.7 \mathrm{~Hz}) ;{ }^{13} \mathrm{C}$ NMR $(101$ $\left.\mathrm{MHz}, \mathrm{CDCl}_{3}\right) \delta 146.8,129.2,115.6,111.8,81.9,77.6,58.3,48.3,31.4,30.3,29.0,28.6,23.0,22.9$, 22.6, 18.8, 14.1; IR 2955 (m), 2930 (s), 2929 (s), 2856 (m), 1699 (w), 1599 (s), 1505 (s), 1483 (w), $1482(w), 1463$ (w), $1366(\mathrm{~s}), 1347$ (m), $1346(\mathrm{~m}), 1296(\mathrm{w}), 1244(\mathrm{w}), 1216(\mathrm{w}), 1215(\mathrm{w}), 1179(\mathrm{w})$, $1178(w), 1161(w), 1036(w), 1036(w), 994(w), 958(w), 958(w), 911(w), 858(w)$; HRMS (ESI) calcd for $\mathrm{C}_{19} \mathrm{H}_{28} \mathrm{~N}^{+}[\mathrm{M}+\mathrm{H}]^{+} 270.2216$; found 270.2222 .

1-(4-Methoxyphenyl)-2-(non-2-yn-1-yl)pyrrolidine (10ja): was prepared from N-para- methoxyphenyl amine 9j (76.5 mg, $0.400 \mathrm{mmol})$ and octynyl bromide (6a) $(97.8 \mathrm{mg}, 0.520 \mathrm{mmol})$. It was obtained as a yellow oil (71.0 mg, $0.237 \mathrm{mmol}, 59 \%$ yield). $\mathrm{R}_{\mathrm{f}} 0.79$ (Hexane/EtOAc 5/1); ${ }^{1} \mathrm{H}$ NMR (400 $\left.\mathrm{MHz}, \mathrm{CDCl}_{3}\right) \delta 6.85(\mathrm{~m}, 2 \mathrm{H}), 6.56(\mathrm{~m}, 2 \mathrm{H}), 3.83-3.74(\mathrm{~m}, 1 \mathrm{H}), 3.76(\mathrm{~d}, 2 \mathrm{H}, J=1.6 \mathrm{~Hz}), 3.41(\mathrm{~m}, 1$ H), $3.12(\mathrm{~m}, 1 \mathrm{H}), 2.55$ (ddd, $1 \mathrm{H}, J=16.5,2.3,2.3 \mathrm{~Hz}), 2.17(\mathrm{~m}, 2 \mathrm{H}), 2.13-1.95$ (m, $5 \mathrm{H}), 1.52$ (m, 2 $\mathrm{H}), 1.46-1.24(\mathrm{~m}, 6 \mathrm{H}), 0.91(\mathrm{t}, 3 \mathrm{H}, J=6.8 \mathrm{~Hz}) ;{ }^{13} \mathrm{C} \mathrm{NMR}\left(101 \mathrm{MHz}, \mathrm{CDCl}_{3}\right) \delta 150.9,141.8,115.1$, 112.6, 81.8, 77.7, 58.8, 56.0, 49.0, 31.4, 30.4, 29.0, 28.6, 23.2, 22.6, 18.8, 14.1; IR $3045(\mathrm{w}), 2952(\mathrm{~m})$, $2930(\mathrm{~m}), 2857(\mathrm{w}), 2834(\mathrm{w}), 1622(\mathrm{w}), 1574(\mathrm{w}), 1515(\mathrm{~s}), 1485(\mathrm{w}), 1463(\mathrm{w}), 1365(\mathrm{w}), 1340(\mathrm{w})$, 
$1329(w), 1284(w), 1242(\mathrm{~s}), 1179$ (w), $1044(\mathrm{~m}), 980(\mathrm{w}), 961(\mathrm{w}), 960(\mathrm{w}), 911(\mathrm{w}), 888(\mathrm{w}), 813$

(m); HRMS (ESI) calcd for $\mathrm{C}_{20} \mathrm{H}_{30} \mathrm{NO}^{+}[\mathrm{M}+\mathrm{H}]^{+} 300.2322$; found 300.2319.

\section{General procedure for the oxy- and aminoalkynylation/in situ complete hydrogenation:}

Under inert atmosphere, $\mathrm{Pd}(\mathrm{dba})_{2}(11.5 \mathrm{mg}, 0.0200 \mathrm{mmol}, 0.05$ equiv), DPEPHos (16.1 mg, 0.0300 mmol, 0.075 equiv) and $\mathrm{NaO} t \mathrm{Bu}(50.0 \mathrm{mg}, 0.520 \mathrm{mmol}, 1.3$ equiv) were introduced into a $5 \mathrm{~mL}$ vial, which was then sealed. Toluene was added $(4.6 \mathrm{~mL})$, followed by the bromo acetylene $6(0.520 \mathrm{mmol}$, 1.3 equiv) and the starting material 5 or $9(0.40 \mathrm{mmol}, 1.0$ equiv $)$. The mixture was stirred at $80^{\circ} \mathrm{C}$ for 3 $\mathrm{h}$ and then allowed to cool to rt. Toluene was removed under reduced pressure and $\mathrm{MeOH}$ was added (2.5-3.0 $\mathrm{mL}$ ) followed by palladium on charcoal (two portions of ca. $50 \mathrm{mg}$ ). The mixture was purged with $\mathrm{H}_{2}$ over 10 minutes and stirred under a $\mathrm{H}_{2}$-atmosphere for 24 hours. Upon filtration through celite, the solvent was removed in vacuo and the crude mixture was then directly purified by column chromatography ( $\mathrm{SiO}_{2}$, pentane/EtOAc $98 / 2$ to $\left.96 / 4\right)$.

2-Nonyltetrahydrofuran (11aa): was prepared from 4- penten-1-ol (5a) (34.4 $\mathrm{mg}, 0.400 \mathrm{mmol})$ and octynyl bromide $(\mathbf{6 a})(98.3 \mathrm{mg}, 0.520 \mathrm{mmol})$. It was obtained as a pale yellow oil (40.0 $\mathrm{mg}, 0.202$ mmol, 51\% yield). $\mathrm{R}_{\mathrm{f}} 0.83$ (Hexane/EtOAc 5/1); ${ }^{1} \mathrm{H}$ NMR (400 MHz, $\left.\mathrm{CDCl}_{3}\right) \delta 3.85$ (ddd, $1 \mathrm{H}, J=8.5$, 7.0, $6.0 \mathrm{~Hz}$ ), 3.77 (ddd,1 H, $J=14.6,7.0,6.0 \mathrm{~Hz}), 3.70(\mathrm{ddd}, 1 \mathrm{H}, J=7.5,7.5,6.0 \mathrm{~Hz}), 1.95(\mathrm{~m}, 1 \mathrm{H})$, 1.91-1.79 (m, $2 \mathrm{H}), 1.56(\mathrm{~m}, 1 \mathrm{H}), 1.48-1.20(\mathrm{~m}, 14 \mathrm{H}), 1.47-1.38(\mathrm{~m}, 2 \mathrm{H}), 0.87(\mathrm{t}, 3 \mathrm{H}, J=6.6 \mathrm{~Hz}) ;{ }^{13} \mathrm{C}$ NMR $\left(101 \mathrm{MHz} \mathrm{CDCl}_{3}\right) \delta 79.5,67.6,35.7,31.9,31.4,29.8,29.6,29.6,29.3,26.4,25.7,22.7,14.1$; IR 2957 (m), 2923 (s), 2872 (m), 2854 (s), 1489 (w), $1465(w), 1379(w), 1189(w), 1180(w), 1179(w)$, $1178(w), 1177(w), 1174(w), 1173(w), 1070(\mathrm{~m}), 1039(w), 1026(w), 943(w), 922(w), 904(w), 870$ (w), $861(w), 850(w)$; HRMS (ESI) calcd for $\mathrm{C}_{13} \mathrm{H}_{27} \mathrm{O}^{+}[\mathrm{M}+\mathrm{H}]^{+}$199.2056; found 199.2056.

tert-Butyl 2-nonylpyrrolidine-1-carboxylate (12aa): was prepared from N-Boc-4-pentenamine (9a) $(74.5 \mathrm{mg}, 0.400 \mathrm{mmol})$ and octynyl bromide $(\mathbf{6 a})(98.3 \mathrm{mg}, 0.520 \mathrm{mmol})$. It was obtained as a pale yellow oil (87.1 mg, $0.293 \mathrm{mmol}, 73 \%$ yield); $\mathrm{R}_{\mathrm{f}} 0.83$ (Hexane/EtOAc 5/1). The product was obtained as a 
mixture of rotamers. In order to characterize it, it was subjected to deprotection of the amino group according to the general procedure.

2-Nonylpyrrolidine (12aa'): was obtained as a yellow oil (61.1 mg, $0.310 \mathrm{mmol}$, quantitative); ${ }^{1} \mathrm{H}$ NMR (400 MHz, $\left.\mathrm{CDCl}_{3}\right) \delta 4.98($ br s, $1 \mathrm{H}), 3.13-3.04(\mathrm{~m}, 2 \mathrm{H}), 2.94$ (ddd, $1 \mathrm{H}, J=10.9,8.3,6.4 \mathrm{~Hz}$ ), $1.95(\mathrm{~m}, 1 \mathrm{H}), 1.89-1.72(\mathrm{~m}, 2 \mathrm{H}), 1.58(\mathrm{~m}, 1 \mathrm{H}), 1.50-1.40(\mathrm{~m}, 1 \mathrm{H}), 1.39-1.20(\mathrm{~m}, 15 \mathrm{H}),$,0.86 (t, $3 \mathrm{H}$, $J=6.6 \mathrm{~Hz}) ;{ }^{13} \mathrm{C} \mathrm{NMR}\left(101 \mathrm{MHz}, \mathrm{CDCl}_{3}\right) \delta 59.7,45.7,34.9,31.9,31.3,29.6,29.5,29.5,29.3,27.2$, 24.7, 22.6, 14.1; IR 3424 (w), 2957 (m), 2924 (s), 2873 (w), 2854 (s), 1678 (s), 1525 (w), 1524 (w), 1460 (m), 1414 (m), 1379 (w), 1344 (w), 1201 (s), 1176 (s), 1133 (s), 1047 (w), $1036(\mathrm{w}), 1026$ (w), $937(w), 930(w), 929(w), 909(w), 908(w), 899(w), 831(\mathrm{~m}), 815(w)$; HRMS (ESI) calcd for $\mathrm{C}_{13} \mathrm{H}_{28} \mathrm{~N}^{+}[\mathrm{M}+\mathrm{H}]^{+}$198.2216; found 198.2219.

\section{$[\operatorname{Pd}(\operatorname{allyl})(\operatorname{cod})]\left(\mathrm{BF}_{4}\right)_{2}$}

$$
\left[\mathrm{Pd}(\text { allyl)Cl }]_{2} \underset{\mathrm{CH}_{2} \mathrm{Cl}_{2}, \mathrm{rt}}{\stackrel{\mathrm{AgBF}_{4}, \mathrm{cod}}{\longrightarrow}}[\mathrm{Pd}(\text { allyl })(\mathrm{cod})]\left(\mathrm{BF}_{4}\right)_{2}\right.
$$

Following a reported procedure, ${ }^{39}[\mathrm{Pd}(\text { allyl }) \mathrm{Cl}]_{2}\left(300 \mathrm{mg}, 0.820 \mathrm{mmol}, 1.0\right.$ equiv) and $\mathrm{AgBF}_{4}(314 \mathrm{mg}$, $1.61 \mathrm{mmol}, 2.0$ equiv) were introduced into a 2-necked flask under $\mathrm{N}_{2} . \mathrm{CH}_{2} \mathrm{Cl}_{2}(8.0 \mathrm{~mL})$ was then added and the solution stirred at room temperature for 15 minutes. cod $(0.33 \mathrm{~mL}, 1.6 \mathrm{mmol}, 2.0$ equiv $)$ was then added and the solution was stirred for $1 \mathrm{~h}$. Upon removal of the formed precipitate by filtration through celite, the resulting solution was treated with $\mathrm{Et}_{2} \mathrm{O}(50 \mathrm{~mL})$ in order to induce the precipitation of the product. The latter was removed by filtration and washed with $\mathrm{Et}_{2} \mathrm{O}(3 \times 10 \mathrm{~mL})$ and dried in vacuo. The solid was taken up in $\mathrm{CH}_{2} \mathrm{Cl}_{2}$ and passed through a cotton wool plug; $\mathrm{Et} 2 \mathrm{O}(2 \times 15 \mathrm{~mL})$ was again added to precipitate out the product, which was dried in vacuo. Complex $[\mathrm{Pd}($ allyl $)(\operatorname{cod})]\left(\mathrm{BF}_{4}\right)_{2}$ was finally obtained as a colorless solid (354 mg,1.04 mmol, 63\% yield). ${ }^{1} \mathrm{H}$ NMR (400 MHz, $\left.\mathrm{CDCl}_{3}\right) \delta$ $6.28(\operatorname{broad} \mathrm{d}, 4 \mathrm{H}), 6.10(\mathrm{tt}, J=13.4,7.3 \mathrm{~Hz}, 1 \mathrm{H}), 4.98,(\mathrm{~d}, J=7.3 \mathrm{~Hz}, 2 \mathrm{H}), 3.98(\mathrm{~d}, J=13.4 \mathrm{~Hz}, 2$ $\mathrm{H})$, 2.75-2.55 (m, $6 \mathrm{H}), 2.36(\mathrm{~m}, 2 \mathrm{H}) ;{ }^{13} \mathrm{C} \mathrm{NMR}\left(101 \mathrm{MHz}, \mathrm{CDCl}_{3}\right) \delta 125.6,114.0,112.9$, 29.4. The values for the characterization correspond to the ones reported in literature. ${ }^{40}$ 


\section{[(Cinnamyl)PdCp]}

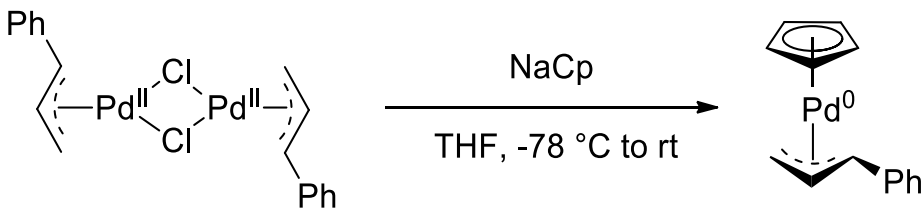

Following a slightly modified version of a reported procedure, ${ }^{10}[\mathrm{Pd}(\text { cinnamyl }) \mathrm{Cl}]_{2}(300 \mathrm{mg}$, 0.579 mmol, 1.0 equiv) was dissolved in THF $(10 \mathrm{~mL})$ and the solution was cooled to $-78{ }^{\circ} \mathrm{C}$. A solution prepared by diluting $\mathrm{NaCp}(2.0 \mathrm{M}, 0.72 \mathrm{~mL}, 1.4 \mathrm{mmol}, 2.5$ equiv) with THF (10 mL) was then added dropwise and the resulting purple mixture was stirred at $-78{ }^{\circ} \mathrm{C}$ for $5 \mathrm{~min}$. It was then allowed to warm to rt and subsequently cooled to $0{ }^{\circ} \mathrm{C}$. The solvent was removed from the cooled solution under reduced pressure and hexane $(10 \mathrm{~mL})$ was added. The dissolved solids were filtered off and the filtrate was concentrated in vacuo to obtain an oily purple solid. Upon addition of hexane $(1.5 \mathrm{~mL})$, crystallization at $-40{ }^{\circ} \mathrm{C}$ afforded [(Cinnamyl)PdCp] $(317 \mathrm{mg}, 0.550 \mathrm{mmol}, 95 \%$ yield $)$ as a dark-purple crystalline solid.

${ }^{1} \mathrm{H}$ NMR (400 MHz, C7 $\left.\mathrm{D}_{8}\right) \delta$ 7.28-7.22 (m, $\left.2 \mathrm{H}\right), 7.04-6.96(\mathrm{~m}, 3 \mathrm{H}), 5.63(\mathrm{~s}, 5 \mathrm{H}), 5.14(\mathrm{ddd}, 1 \mathrm{H}, J=$ 10.3, 10.3, $6.2 \mathrm{~Hz}), 3.84(\mathrm{~d}, 1 \mathrm{H}, J=9.8 \mathrm{~Hz}), 3.36(\mathrm{~d}, 1 \mathrm{H}, J=6.1 \mathrm{~Hz}), 2.16(\mathrm{~d}, 1 \mathrm{H}, J=10.5 \mathrm{~Hz})$. The values for the characterization of [(Cinnamyl)PdCp] correspond to the ones reported in literature. ${ }^{10}$

\section{Large scale reaction for the synthesis of $7 \mathrm{bh}$}

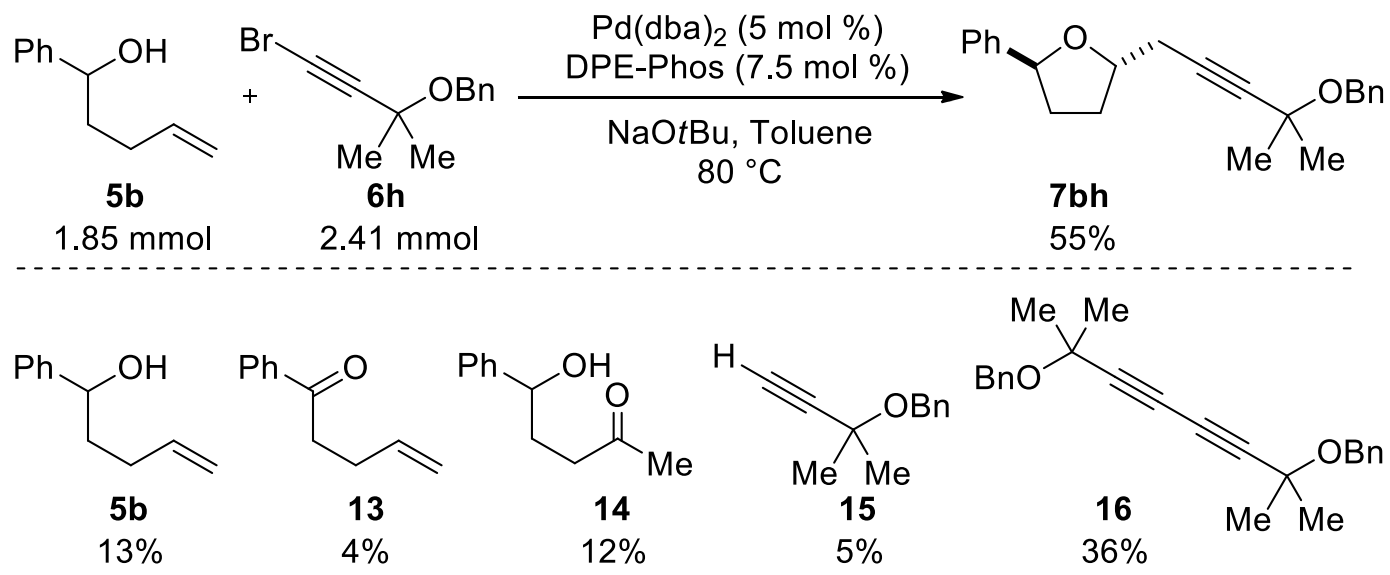


Under inert atmosphere, $\mathrm{Pd}(\mathrm{dba})_{2}(53.2 \mathrm{mg}, 0.0925 \mathrm{mmol}, 0.05$ equiv), DPEPHos (74.9 mg, 0.139 mmol, 0.075 equiv) and $\mathrm{NaO} t \mathrm{Bu}(232 \mathrm{mg}, 2.41 \mathrm{mmol}, 1.3$ equiv) were introduced into a $50 \mathrm{~mL}$ oneneck flask. Toluene $(21.3 \mathrm{~mL})$ was added under an argon atmosphere, followed by the bromo acetylene 6h (610 mg, $2.41 \mathrm{mmol}, 1.3$ equiv) and alcohol $\mathbf{5 b}$ (300 mg, $1.85 \mathrm{mmol}, 1.0$ equiv). The mixture was stirred at $80{ }^{\circ} \mathrm{C}$ for $3 \mathrm{~h}$ and then allowed to cool to room temperature. The solvent was evaporated under reduced pressure. The crude mixture was then directly purified by column chromatography $\left(\mathrm{SiO}_{2}\right.$, pentane/EtOAc 99/1). Fractions containing the inseparable mixture of alkyne $\mathbf{1 5}$ and dimer $\mathbf{1 6}$ were collected and purified again $\left(\mathrm{SiO}_{2}, 98 / 2\right.$ pentane/Et $\left.2 \mathrm{O}\right)$. The isolation and identification showed that $13 \%$ of $\mathbf{5 b}$ (39.5 mg, $0.243 \mathrm{mmol})$ was recovered, $55 \%$ of $7 \mathbf{b h}(338 \mathrm{mg}, 1.01 \mathrm{mmol})$ was formed and the following side-products were generated: ketone $13(12.8 \mathrm{mg}, 0.0799 \mathrm{mmol}, 4 \%)$, hydroxy ketone 14 (40.9 mg, $0.230 \mathrm{mmol}, 12 \%)$, alkyne 15 (21.9 mg, $0.126 \mathrm{mmol}, 5 \%)$ and dimer 16 (152 mg, $0.438 \mathrm{mmol}, 36 \%)$.

1-Phenylpent-4-en-1-one (13): $\mathrm{R}_{\mathrm{f}} 0.37$ (Pentane/EtOAc 20/1); ${ }^{1} \mathrm{H}$ NMR $\left(400 \mathrm{MHz}, \mathrm{CDCl}_{3}\right) \delta 7.96(\mathrm{~m}$, $2 \mathrm{H}), 7.56(\mathrm{~m}, 1 \mathrm{H}), 7.46(\mathrm{~m}, 2 \mathrm{H}), 5.91(\mathrm{~m}, 1 \mathrm{H}), 5.09(\mathrm{dd}, 1 \mathrm{H}, J=17.1,1.5 \mathrm{~Hz}), 5.01(\mathrm{~d}, 1 \mathrm{H}, J=10.2$ $\mathrm{Hz}), 3.07$ (ddd, $2 \mathrm{H}, J=7.3,7.3,2.0 \mathrm{~Hz}), 2.50(\mathrm{~m}, 2 \mathrm{H}) ;{ }^{13} \mathrm{C} \mathrm{NMR}\left(101 \mathrm{MHz}, \mathrm{CDCl}_{3}\right) \delta 199.4,137.3$, $136.9,133.0,128.6,128.0,115.2,37.7,28.1$. The data for the characterization of compound $\mathbf{1 3}$ correspond to the ones reported in the literature. ${ }^{41}$

5-hydroxy-5-phenylpentan-2-one (14): $\mathrm{R}_{\mathrm{f}} 0.05$ (Pentane/EtOAc 20/1); ${ }^{1} \mathrm{H}$ NMR (400 MHz, $\left.\mathrm{CDCl}_{3}\right) \delta$ 7.37-7.30 (m, $3 \mathrm{H}), 7.27(\mathrm{~m}, 2 \mathrm{H}), 4.72(\mathrm{t}, 1 \mathrm{H}, J=6.3 \mathrm{~Hz}), 2.55(\mathrm{t}, 2 \mathrm{H}, J=7.0 \mathrm{~Hz}), 2.13(\mathrm{~s}, 3 \mathrm{H}), 2.02$ $(\mathrm{m}, 2 \mathrm{H}) ;{ }^{13} \mathrm{C}$ NMR $\left(101 \mathrm{MHz}, \mathrm{CDCl}_{3}\right) \delta 209.1,143.9,128.2,127.2,125.4,73.1,39.5,32.3,29.7$. The data for the characterization of compound $\mathbf{1 2}$ correspond to the ones reported in the literature. ${ }^{42}$

(((2-methylbut-3-yn-2-yl)oxy)methyl)benzene (15): $\mathrm{R}_{\mathrm{f}} 0.47$ (Pentane/EtOAc 20/1); ${ }^{1} \mathrm{H}$ NMR (400 $\left.\mathrm{MHz}, \mathrm{CDCl}_{3}\right) \delta$ 7.41-7.31 (m, $\left.4 \mathrm{H}\right), 7.27(\mathrm{~m}, 1 \mathrm{H}), 4.65(\mathrm{~s}, 2 \mathrm{H}), 2.49(\mathrm{~s}, 1 \mathrm{H}), 1.57(\mathrm{~s}, 6 \mathrm{H}) ;{ }^{13} \mathrm{C} \mathrm{NMR}$ $\left(101 \mathrm{MHz} \mathrm{CDCl}_{3}\right) \delta 138.9,128.3,127.7,127.3,86.1,72.2,70.5,66.5,28.8$. The data for the characterization of compound $\mathbf{1 3}$ correspond to the ones reported in the literature. ${ }^{43}$ 
(((4-bromo-2-methylbut-3-yn-2-yl)oxy)methyl)benzene (16): $\mathrm{R}_{\mathrm{f}} 0.40$ (Pentane/EtOAc 20/1); Mp

51.6-53.4 ${ }^{\circ} \mathrm{C} ;{ }^{1} \mathrm{H}$ NMR (400 MHz, $\left.\mathrm{CDCl}_{3}\right) \delta 7.37(\mathrm{~m}, 8 \mathrm{H}), 7.28(\mathrm{~m}, 2 \mathrm{H}), 4.65(\mathrm{~s}, 4 \mathrm{H}), 1.59(\mathrm{~s}, 12 \mathrm{H})$;

${ }^{13} \mathrm{C}$ NMR $\left(101 \mathrm{MHz}, \mathrm{CDCl}_{3}\right) \delta 138.6,128.3,127.7,127.4,81.7,71.0,68.5,66.8,28.7$; IR $3091(\mathrm{w})$, 3067 (w), 3066 (w), $3063(w), 3048(w), 3033(w), 2985(\mathrm{~m}), 2934(w), 2905(w), 2865(w), 2864(w)$, $2838(w), 2374(w), 2357(w), 2150(w), 1948(w), 1871(w), 1810(w), 1745(w), 1705(w), 1606(w)$, $1517(w), 1498(w), 1464(w), 1456(\mathrm{~m}), 1438(w), 1382(\mathrm{~m}), 1360(\mathrm{w}), 1339(\mathrm{w}), 1330(\mathrm{w}), 1330(\mathrm{w})$, $1312(\mathrm{w}), 1303(\mathrm{w}), 1223(\mathrm{~m}), 1185$ (m), $1157(\mathrm{~s}), 1122(\mathrm{w}), 1105(\mathrm{w}), 1086(\mathrm{~m}), 1054(\mathrm{~s}), 1030$ (m), $1003(w), 941(w), 925(w), 912(w), 883(\mathrm{~m}), 847(w), 828(w), 821(w)$; HRMS (ESI) calcd for $\mathrm{C}_{24} \mathrm{H}_{26} \mathrm{NaO}_{2}[\mathrm{M}+\mathrm{Na}]$ 369.1830; found 369.1836.

\section{Acknowledgment}

EPFL, F. Hoffmann-La Roche Ltd and SNF (grant number 200021_119810) are acknowledged for financial support.

Supporting Information. General methods, reaction optimization, kinetic studies and characterization data, including NMR spectra. This material is available free of charge via the Internet at http://pubs.acs.org.

\section{References}

(1) Crimmins, M. T.; She, J. J. Am. Chem. Soc. 2004, 126, 12790.

(2) (a) Shibano, M.; Tsukamoto, D.; Kusano, G. Heterocycles 2002, 57, 1539. (b) Trost, B. M.; Horne, D. B.; Woltering, M. J. Angew. Chem., Int. Ed. 2003, 42, 5987.

(3) (a) Johnson, J. H.; Phillipson, D. W.; Kahle, A. D. J. Antibiot. 1989, 42, 1184. (b) Deng, W.; Overman, L. E. J. Am. Chem. Soc. 1994, 116, 11241.

(4) For reviews, see: (a) Tietze, L. F. Chem. Rev. 1996, 96, 115. (b) Zeni, G.; Larock, R. C. Chem. Rev. 2004, 104, 2285. (c) Beller, M.; Seayad, J.; Tillack, A.; Jiao, H. Angew. Chem., Int. Ed. 2004, 43, 3368. (d) Nakamura, I.; Yamamoto,Y. Chem. Rev. 2004, 104, 2127. (e) Beccalli, E. M.; Broggini, G; Martinelli, M.; Sottocornola, S. Chem. Rev. 2007, 107, 5318. (f) Muniz, K. Angew. Chem., Int. Ed. 2009, 
48, 9412. (g) Beccalli, E. M.; Broggini, G.; Fasana, A.; Rigamonti, M. J. Organomet. Chem. 2011, 696, 277.

(5) Heterocyclization using $\mathrm{Pd}(\mathrm{II}) / \mathrm{Pd}(\mathrm{IV})$-catalysis; with formation of an exocyclic C-O bond: (a) Li, Y.; Song, D.; Dong, V. M. J. Am. Chem. Soc. 2008, 130, 2962. (b) Jensen, K. H.; Webb, J. D.; Sigman, M. S. J. Am. Chem. Soc. 2010, 132, 17471. With formation of an exocyclic C-N bond: (c) Streuff, J.; Hovelmann, C. H.; Nieger, M.; Muniz, K. J. Am. Chem. Soc. 2005, 127, 14586. (d) Muniz, K. J. Am. Chem. Soc. 2007, 129, 14542. (e) Muniz, K.; Hovelmann, C. H.; Streuff, J. J. Am. Chem. Soc. 2008, 130, 763. (f) Desai, L. V.; Sanford, M. S. Angew. Chem., Int. Ed. 2007, 46, 5737. With formation of an exocyclic C-C bond: (g) Sibbald, P. A.; Rosewall, C. F.; Swartz, R. D.; Michael, F. E. J. Am. Chem. Soc. 2009, 131, 15945.

(6) Heterocyclization using $\mathrm{Pd}(0) / \mathrm{Pd}(\mathrm{II})$-catalysis. Heterocarbonylation reactions: (a) Hegedus, L. S.; Allen, G. F.; Olsen, D. J. J. Am. Chem. Soc. 1980, 102, 3583. (b) Semmelhack, M. F.; Zhang, N. J. Org. Chem. 1989, 54, 4483. (c) Cernak, T. A.; Lambert, T. H. J. Am. Chem. Soc. 2009, 131, 3124. Heteroarylation and heterovinylation reactions: (d) Semmelhack, M. F.; Epa, W. R. Tetrahedron Lett. 1993, 34, 7205. (e) Lira, R.; Wolfe, J. P. J. Am. Chem. Soc. 2004, 126, 13906. (f) Ney, J. E.; Wolfe, J. P. Angew. Chem., Int. Ed. 2004, 43, 3605. (g) Wolfe, J. P.; Rossi, M. A. J. Am. Chem. Soc. 2004, 126, 1620. (h) Hay, M. B.; Hardin, A. R.; Wolfe, J. P. J. Org. Chem. 2005, 70, 3099. (i) Ney, J. E.; Hay, M. B.; Yang, Q. F.; Wolfe, J. P. Adv. Synth. Catal. 2005, 347, 1614. (j) Neukom, J. D.; Perch, N. S.; Wolfe, J. P. J. Am. Chem. Soc. 2010, 132, 6276. (k) Mai, D. N.; Wolfe, J. P. J. Am. Chem. Soc. 2010, 132, 12157. (1) Babij, N. R.; Wolfe, J. P. Angew. Chem., Int. Ed. 2012, 51, 4128.

(7) (a) Seregin, I. V.; Ryabova, V.; Gevorgyan, V. J. Am. Chem. Soc. 2007, 129, 7742. (b) Gu, Y.; Wang, X. M. Tetrahedron Lett. 2009, 50, 763. (c) Tobisu, M.; Ano, Y.; Chatani, N. Org. Lett. 2009, 11, 3250. (d) Ano, Y.; Tobisu, M.; Chatani, N. Org. Lett. 2011, 14, 354. (e) Ano, Y.; Tobisu, M.; Chatani, N. J. Am. Chem. Soc. 2011, 133, 12984. (f) Ziadi, A.; Correa, A.; Martin, R. Chem. Commun. 2013, DOI: 10.1039/C2CC37281A. (g) Tolnai, G. L.; Ganss, S.; Brand, J. P.; Waser, J. Org. Lett. 2013, 16, 112. For reviews on electrophilic alkynylation, see: (h) Dudnik, A. S.; Gevorgyan, V. Angew. Chem., Int., Ed. 
2010, 49, 2096. (i) Messaoudi, S.; Brion, J. D.; Alami, M. Eur. J. Org. Chem. 2010, 6495. (j) Brand, J. P.; Waser, J. Chem. Soc. Rev. 2012, 41, 4165.

(8) Nicolai, S.; Waser, J. Org. Lett. 2011, 13, 6324.

(9) (a) Nicolai, S.; Erard, S.; Fernández González, D.; Waser, J. Org. Lett. 2009, 12, 384. (b) Nicolai, S.; Piemontesi, C.; Waser, J. Angew. Chem., Int. Ed. 2011, 50, 4680.

(10) Fraser, A. W.; Besaw, J. E.; Hull, L. E.; Baird, M. C. Organometallics 2012, 31, 2470.

(11) See table S3 in the supporting information for a full list of tested enone ligands.

(12) (a) Kranenburg, M.; Kamer, P. C. J.; van Leeuwen, P. W. N. M. Eur. J. Inorg. Chem. 1998, 1998, 155. (b) Dierkes, P.; W. N. M. van Leeuwen, P. J. Chem. Soc., Dalton Trans. 1999, 1519. (c) van Leeuwen, P. W. N. M.; Kamer, P. C. J.; Reek, J. N. H.; Dierkes, P. Chem. Rev. 2000, 100, 2741. (d) Birkholz, M.-N.; Freixa, Z.; van Leeuwen, P. W. N. M. Chem. Soc. Rev. 2009, 38, 1099.

(13) See supporting information for a list of tested additives.

(14) On larger scale, re-optimization of the catalyst and ligand loadings led to the use of 5 mol \% $\operatorname{Pd}(\mathrm{dba})_{2}$ and $7.5 \mathrm{~mol} \%$ DPEPHos. See supporting information for more details.

(15) (a) Mu, F.; Lee, D. J.; Pryor, D. E.; Hamel, E.; Cushman, M. J. Med. Chem., 2002, 45, 4774. The halogenoalkynes used in these studies were synthesized using known procedures: (b) Cossy, J.; Tresnard, L.; Pardo, D. G. Eur. J. Org. Chem. 1999, 1925. (c) Trost, B. M.; Fandrick, D. R.; Dinh, D. C. J. Am. Chem. Soc. 2005, 127, 14186. (d) Buzas, A.; Gagosz, F. J. Am. Chem. Soc. 2006, 128, 12614. (e) Gramlich, P. M. E.; Warncke, S.; Gierlich, J.; Carell, T. Angew. Chem., Int. Ed. 2008, 47, 3442. (f) Sui, B.; Yeh, E. A. H.; Curran, D. P. J. Org. Chem. 2010, 75, 2942. (g) Schmidt, R. G.; Bayburt, E. K.; Latshaw, S. P.; Koenig, J. R.; Daanen, J. F.; McDonald, H. A.; Bianchi, B. R.; Zhong, C.; Joshi, S.; Honore, P.; Marsh, K. C.; Lee, C.-H.; Faltynek, C. R.; Gomtsyan, A. Bioorg. Med. Chem. Lett. 2011, 21, 1338. (h) Nishimura, T.; Nagaosa, M.; Hayashi, T. Tetrahedron Lett. 2011, 52, 2185.

(16) Alcohols 5b and 5c were synthesized using known procedures: (a) Janza, B.; Studer, A. J. Org. Chem. 2005, 70, 6991. (b) Habel, A.; Boland, W. Org. Biomol. Chem. 2008, 16, 1601. 
(17) The protected amines used in this study were synthesized using known procedures: Ref. 6f. (a)

Schomaker, J. M.; Travis, B. R.; Borhan, B. Org. Lett., 2003, 5, 3089. (b) Dolman, S. J.; Schrock, R. R.; Hoveyda, A. H. Org. Lett. 2003, 5, 4899. (c) Ma, S.; Ni, B. Chem. Eur. J. 2004, 10, 3286. (d) Michael, F. E.; Cochran, B. M. J. Am. Chem. Soc., 2006, 128, 4246. (e) Gribkov, D. V.; Hultzsch, K. C.; Hampel, F. J. Am. Chem. Soc., 2006, 128, 3748. (f) Bertrand, M. B.; Leathen, M. L.; Wolfe, J. P. Org. Lett. 2007, 9, 457. (g) Lemière, G.; Gandon, V.; Cariou, K.; Hours, A.; Fukuyama, T.; Dhimane, A.-L.; Fensterbank, L.; Malacria, M. J. Am. Chem. Soc. 2009, 131, 2993. (h) Gresser, M. J.; Wales, S. M.; Keller, P. A. Tetrahedron 2010, 66, 6965. (i) Li, X.; Li, C.; Zhang, W.; Lu, X.; Han, S.; Hong, R. Org. Lett. 2010, 12, 1696.

(18) For an example of one-pot metathesis-hydrogenation, see: Fürstner, A.; Leitner, A. Angew. Chem., Int. Ed. 2003, 42, 308. The formation of the alkane product was not observed in the absence of $\mathrm{Pd} / \mathrm{C}$, which indicated that the heterogenous catalyst was required for hydrogenation.

(19) (a) Liu Q; Burton, D. J.; Tetrahedron Lett. 1997, 38, 437. (b) Damle, S. V.; Seomoon, D.; Lee, P. H. J. Org. Chem. 2003, 68, 7085. An alternative mechanism would be insertion of II onto the triple bond of $\mathbf{6 h}$ followed by $\beta$-bromide elimination. Overall, this process is a reductive coupling leading to $\operatorname{Pd}(\mathrm{II})$. The active $\mathrm{Pd}(0)$ catalyst would be most probably regenerated after one of the $\beta$-hydride elimination proposed in the catalytic cycle.

(20) A similar explanation has also been proposed in the case of oxyarylation, see Ref. $6 \mathrm{~h}$.

(21) Another possibility for the formation of $\mathbf{1 4}$ would be direct Wacker like oxidation of the olefin. However, as special care has been taken to exclude air and moisture during the reaction, this mechanism appears less probable.

(22) Crude analysis of the initial rate of the reactions would give reaction orders of 0.6, 0.6 and 1.4 for alcohol 5b, alkynyl bromide $\mathbf{6 h}$ and $\mathrm{Pd}(\mathrm{dba})_{2}$ respectively. However, the many side reactions and the catalyst deactivation occurring during oxyalkynylation limit the significance of these results.

(23) Bertrand, M. B.; Wolfe, J. P. Tetrahedron 2005, 61, 6447.

(24) Basel, Y.; Hassner, A. Synthesis 2001, 550. 
(25) Legeay, J. C.; Lewis, W.; Stockman R. A. Chem. Commun. 2009, 2207.

(26) Curran, D. P.; Liu, H. J. Chem. Soc., Perkin Trans. 1 1994, 1377.

(27) Wang, L.; Thai, K.; Gravel, M. Org. Lett. 2009, 11, 891.

(28) Rubin, Y.; Lin, S. S.; Knobler, C. B.; Anthony, J.; Boldi, A. M.; Diederich, F. J. Am. Chem. Soc. 1991, 113, 6943.

(29) Yamagishi, M.; Nishigai, K.; Hata,T.; Urabe, H. Org. Lett. 2011, 13, 4873.

(30) Salvi, L.; Jeon, S.-J.; Fisher, E. L.; Carroll, P. J.; Walsh, P. J. J. Am. Chem. Soc. 2007, 129, 16119.

(31) The peaks at 18.1 and $18.0 \mathrm{ppm}$ correspond to the rotamers of the TIPS protecting group.

(32) The trans-stereochemistry of the tetrahydrofuran products and the cis-stereochemistry of the pyrrolidine products had been assigned in our previous work with silyl acetylenes. ${ }^{8}$ The stereochemistry in this work was deduced by analogy and comparison of the NMR spectra.

(33) Diastereoisomeric ratio calculated by integration of peaks at $\delta 4.14$ (Major diastereoisomer) and $\delta 4.00$ (Minor diastereoisomer).

(34) Diastereoisomeric ratio calculated by integration of peaks at $\delta 3.36$ (Major diastereoisomer) and $\delta 3.56$ (Minor diastereoisomer).

(35) Diastereoisomeric ratio calculated by integration of peaks at $\delta 3.13$ (Major diastereoisomer) and $\delta$ 3.31 (Minor diastereoisomer).

(36) Diastereoisomeric ratio calculated by integration of peaks at $\delta 3.14$ (Major diastereoisomer) and $\delta 3.31$ (Minor diastereoisomer). Full assignment based on COSY.

(37) Diastereoisomeric ratio calculated by integration of peaks at $\delta 3.05$ (Major diastereoisomer) and $\delta 2.97$ (Minor diastereoisomer).

(38) Diastereoisomeric ratio calculated by integration of peaks at $\delta 3.20$ (Major diastereoisomer) and $\delta 3.07$ (Minor diastereoisomer).

(39) Mccormick, J. B.; Jaynes, E. N.; Kaplan, R. I.; Clark, H. C.; Ruddick, J. D. In Inorg. Synth.; John Wiley \& Sons, Inc.: 2007, p 216. 
(40) Hegedus, L. S; McKearin, J. M. J. Am. Chem. Soc. 1982, 104, 2444.

(41) Hok, S.; Schore, N. E. J. Org. Chem. 2006, 71, 1736.

(42) Hattori, K.; Sajiki, H.; Hirota, K. Tetrahedron 2001, 57, 4817.

(43) Jiang, M. X.-W. ; Rawat, M. ; Wulff, W. D. J. Am. Chem. Soc. 2004, 126, 5970. 


\section{Supporting information}

$\operatorname{Pd}(0)$-Catalyzed Alkene Oxy- and Aminoalkynylation with Aliphatic Bromoacetylenes

$$
\text { Stefano Nicolai, Raha Sedigh-Zadeh and Jérôme Waser* }
$$

Laboratory of Catalysis and Organic Synthesis, Ecole Polytechnique Fédérale de Lausanne, EPFL SB ISIC

LCSO, BCH 4306, 1015 Lausanne, Switzerland

jerome.waser@epfl.ch

56 Pages

1. General methods

p. S2

2. Reaction Optimization

p. S3

3. Kinetic data

p. S6

4. Spectra of New Compounds

p. S14 


\section{General Methods}

All reactions were carried out in oven dried glassware under an atmosphere of nitrogen, unless stated otherwise. For quantitative flash chromatography technical grade solvents were used. For flash chromatography for analysis, HPLC grade solvents from Sigma-Aldrich were used. THF, $\mathrm{Et}_{2} \mathrm{O}, \mathrm{CH}_{3} \mathrm{CN}$, toluene, hexane and $\mathrm{CH}_{2} \mathrm{Cl}_{2}$ were dried by passage over activated alumina under nitrogen atmosphere $\left(\mathrm{H}_{2} \mathrm{O}\right.$ content $<30 \mathrm{ppm}$, Karl-Fischer titration). All chemicals were commercially available and used as such unless stated otherwise. Chromatographic purification was performed as flash chromatography using silica 40-63, $60 \AA$, using the solvents indicated as eluent with 0.1-0.5 bar pressure (unprotected pyrrolidines were eluted using DCM/ULTRA; ULTRA; ULTRA: DCM/MeOH/(NH3 $25 \%$ inwater) 75/25/5). TLC was performed on silica gel 60 F254 TLC glass plates or aluminium plates and visualized with UV light, permanganate stain, CAN stain or Anisaldehyde stain. Melting points were measured on a melting point apparatus using open glass capillaries, the data is uncorrected. ${ }^{1} \mathrm{H}-\mathrm{NMR}$ spectra were recorded on a 400 $\mathrm{MHz}$ spectrometer in chloroform-d, all signals are reported in ppm with the internal chloroform signal at $7.26 \mathrm{ppm}$. The data is being reported as $(\mathrm{s}=$ singlet, $\mathrm{d}=$ doublet, $\mathrm{t}=$ triplet, $\mathrm{q}=$ quadruplet, quint $=$ quintet, $\mathrm{m}=$ multiplet or unresolved, $\mathrm{br}=$ broad signal, coupling constant(s) in $\mathrm{Hz}$, integration; interpretation based on chemical shift, unless stated otherwise). ${ }^{13} \mathrm{C}$-NMR spectra were recorded with ${ }^{1} \mathrm{H}$-decoupling on a $100 \mathrm{MHz}$ spectrometer in chloroform-d, DMSO$\mathrm{d}_{6}, \mathrm{CD}_{2} \mathrm{Cl}_{2}$ or $\mathrm{CD}_{3} \mathrm{OD}$, all signals are reported in ppm with the internal chloroform signal at 77.0 ppm. Infrared spectra were recorded on a FT-IR spectrophotometer with an ATR and a ZnSe prisma and are reported as $\mathrm{cm}^{-1}(\mathrm{w}=$ weak, $\mathrm{m}=$ medium, $\mathrm{s}=$ strong, $\mathrm{sh}=$ shoulder, $\mathrm{br}=$ broad). Gas chromatographic and low resolution mass spectrometric measurements were performed using a fused silica column (length: $30 \mathrm{~m}$, diameter: $0.32 \mathrm{~mm}$ ) and Helium as carrier gas. High resolution mass spectrometric measurements were performed via Q-TOF API or ESI. 


\section{Reaction Optimization}

\section{GC-MS Quantification:}

A $0.0 .30 \mathrm{M}$ standard solution was prepared by dissolving pentadecane $(0.100 \mathrm{~mL}, 0.364 \mathrm{mmol})$ in DCM (11.9 mL).

2-(Non-2-yn-1-yl)tetrahydrofuran (7aa) $(25.7 \mathrm{mg}, 0.132 \mathrm{mmol})$ was dissolved in $\mathrm{CH}_{2} \mathrm{Cl}_{2}$ (ca. $4.41 \mathrm{~mL}$ ) (solution $\mathrm{O}$ ).

- $0.50 \mathrm{~mL}$ of solution $\mathrm{O}$ were diluted by adding DCM $(1.50 \mathrm{~mL})$ to obtain solution $\mathrm{A}$;

- $0.50 \mathrm{~mL}$ of solution $\mathrm{O}$ were mixed with $0.25 \mathrm{~mL}$ standard solution $0.030 \mathrm{M}$ and diluted by adding $\mathrm{CH}_{2} \mathrm{Cl}_{2}(1.25 \mathrm{~mL})$ to obtain solution $\mathrm{B}$;

- $0.50 \mathrm{~mL}$ of solution $\mathrm{O}$ were mixed with $0.50 \mathrm{~mL}$ standard solution $0.030 \mathrm{M}$ and diluted by adding $\mathrm{CH}_{2} \mathrm{Cl}_{2}(1.00 \mathrm{~mL})$ to obtain solution $\mathrm{C}$;

- $0.5 \mathrm{~mL}$ of solution $\mathrm{O}$ were mixed with $1.00 \mathrm{~mL}$ standard solution $0.025 \mathrm{M}$ and diluted by adding $\mathrm{CH}_{2} \mathrm{Cl}_{2}(0.50 \mathrm{~mL})$ to obtain solution $\mathrm{D}$.

GC-MS chromatograms were acquired for solutions A, B, C and D and in each of them the ratio between the integrals of the signals corresponding to the internal standard (retention time: 15.9 $\mathrm{min}$ ) and to the compound 7aa (retention time: $16.2 \mathrm{~min}$ ) was calculated. These observed ratios by integration of the chromatogram peaks and the ratios (mmol pentadecane/mmol 7aa) were used as the axis of the calibration graph.

\section{Calibration Curve}

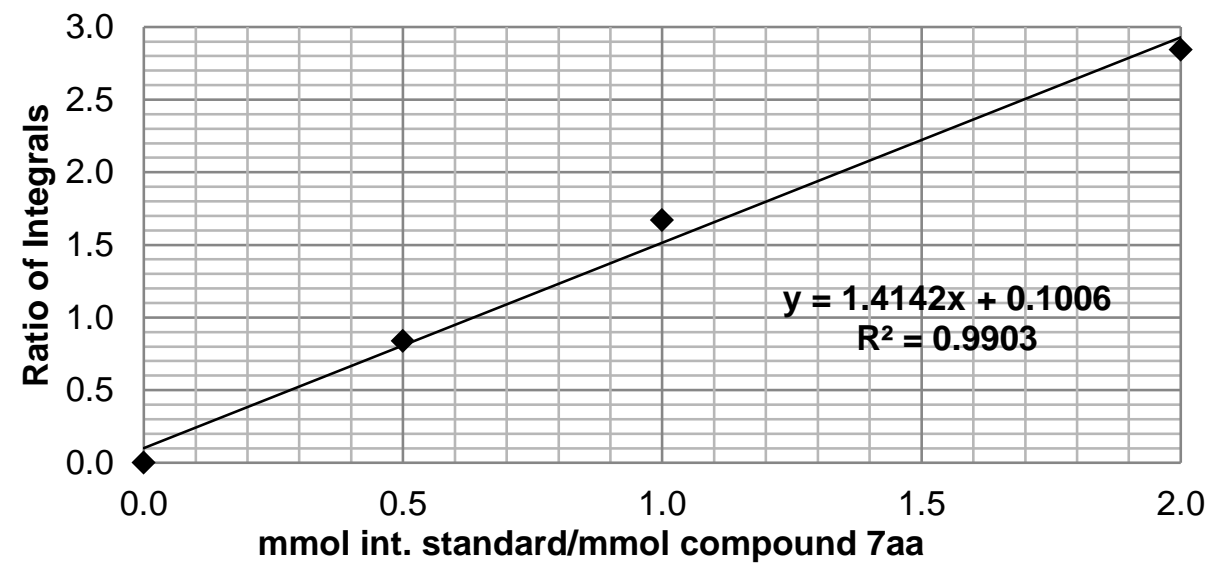

Table S1. Screening of Pd sources and alkynyl reagents 


\begin{tabular}{|c|c|c|c|}
\hline$\overbrace{5 a}^{\mathrm{OH}}$ & $\underbrace{}_{M_{4}} \mathrm{Me}$ & $\begin{array}{l}\text { [Pd] }(2 \mathrm{~mol} \%) \\
\text { NaOtBu } \\
\text { Toluene, } 80^{\circ} \mathrm{C}\end{array}$ & $4 \quad \mathrm{Me}$ \\
\hline Entry & $\mathrm{X}=\mathrm{C}_{6} \mathrm{H}_{13}$ & [Pd]-Catalyst & Yield $(\%)^{\mathrm{a}}$ \\
\hline 1 & $\mathrm{Br}$ & $\mathrm{Pd}_{2}(\mathrm{dba})_{3}$ & 44 \\
\hline 2 & $\mathrm{Br}$ & $\mathrm{PdCl}_{2}\left(\mathrm{PPh}_{3}\right)_{2}$ & 31 \\
\hline 3 & $\mathrm{Br}$ & $\mathrm{Pd}(\mathrm{OAc})_{2}$ & 30 \\
\hline 4 & $\mathrm{Br}$ & $(\mathrm{NHC}) \mathrm{Pd}($ allyl $) \mathrm{Cl}(\mathbf{8})^{\mathrm{b}}$ & 56 \\
\hline 5 & $\mathrm{Br}$ & $(\mathrm{NHC}) \mathrm{Pd}($ allyl $) \mathrm{Cl}(\mathbf{8})^{\mathrm{b}}$ & $-c$ \\
\hline 6 & $\mathrm{Br}$ & {$[\mathrm{Pd}($ allyl $)(\mathrm{cod})]\left(\mathrm{BF}_{4}\right)_{2}$} & 50 \\
\hline 7 & $\mathrm{Br}$ & $\mathrm{Pd}\left(\mathrm{PPh}_{3}\right)_{4}$ & 33 \\
\hline 8 & $\mathrm{Br}$ & {$[\mathrm{Pd}($ cinnamyl $) \mathrm{Cp}]$} & 50 \\
\hline 9 & $\mathrm{Br}$ & $\operatorname{Pd}(\mathrm{dba})_{2}$ & 51 \\
\hline 10 & $\mathrm{Cl}$ & $\operatorname{Pd}(d b a)_{2}$ & traces \\
\hline 11 & I & $\operatorname{Pd}(\mathrm{dba})_{2}$ & 16 \\
\hline
\end{tabular}

(a) Conditions: $0.15 \mathrm{mmol}$ 5a, $0.006 \mathrm{mmol}$ [Pd] (4 mol \%), $0.012 \mathrm{mmol}$ DPE-Phos (8 mol $\%$ ), $0.225 \mathrm{mmol} 1$-halooct-1-yne (1.5 equiv), $0.225 \mathrm{mmol} \mathrm{NaO} t \mathrm{Bu}$ (1.5 equiv), $0.8 \mathrm{~mL}$ toluene, $3 \mathrm{~h}, 75-80^{\circ} \mathrm{C}$, yield was determined by GC-MS; (b) (NHC)Pd(allyl) $\mathrm{Cl}=$ Allyl[1,3bis(mesityl)imidazol-2-ylidene]palladium chloride; (c) no ligand added.

Table S2. Screening of ligands and bases.

\begin{tabular}{|c|c|c|c|}
\hline$\overbrace{5 a}^{O H}+$ & $\overbrace{6 a} \widehat{T}_{4} \mathrm{Me}$ & $\begin{array}{c}\mathrm{Pd}(\mathrm{dba})_{2}(2 \mathrm{~mol} \%) \\
\text { Ligand }(4 \mathrm{~mol} \%)\end{array}$ & 7 aа \\
\hline Entry & Base & Ligand & Yield $(\%)^{\mathrm{a}}$ \\
\hline 1 & $\mathrm{NaO} t \mathrm{Bu}$ & DPE-Phos & 51 \\
\hline 2 & $\mathrm{NaO} t \mathrm{Bu}$ & DPE-Phos & $38^{\mathrm{b}}$ \\
\hline 3 & $\mathrm{NaO} t \mathrm{Bu}$ & Xant-Phos & 29 \\
\hline 4 & $\mathrm{NaO} t \mathrm{Bu}$ & dppf & 16 \\
\hline 5 & $\mathrm{NaO} t \mathrm{Bu}$ & Seg-Phos & - \\
\hline
\end{tabular}




\begin{tabular}{cclc}
6 & $\mathrm{NaO} t \mathrm{Bu}$ & BINAP & - \\
7 & $\mathrm{KO} t \mathrm{Bu}$ & DPE-Phos & traces \\
8 & $\mathrm{LiO} t \mathrm{Bu}$ & DPE-Phos & traces \\
9 & $\mathrm{NaHMDS}$ & DPE-Phos & 24 \\
10 & $\mathrm{NaF}$ & DPE-Phos & - \\
11 & $\mathrm{NaOAc}$ & DPE-Phos & - \\
13 & $\mathrm{Na}_{2} \mathrm{CO}_{3}$ & DPE-Phos & - \\
\hline
\end{tabular}

(a) Conditions: $0.15 \mathrm{mmol}$ 5a, $0.006 \mathrm{mmol} \mathrm{Pd}(\mathrm{dba})_{2}(4 \mathrm{~mol} \%), 0.012 \mathrm{mmol}$ ligand ( $8 \mathrm{~mol} \%), 0.225 \mathrm{mmol} \mathbf{6 a}$ (1.5 equiv), $0.225 \mathrm{mmol}$ base (1.5 equiv), 0.8 $\mathrm{mL}$ toluene, $3 \mathrm{~h}, 75-80^{\circ} \mathrm{C}$, yield was determined by GC-MS; (b) $0.0060 \mathrm{mmol}$ DPE-Phos (4 mol \%).

Table S3. Screening of additives

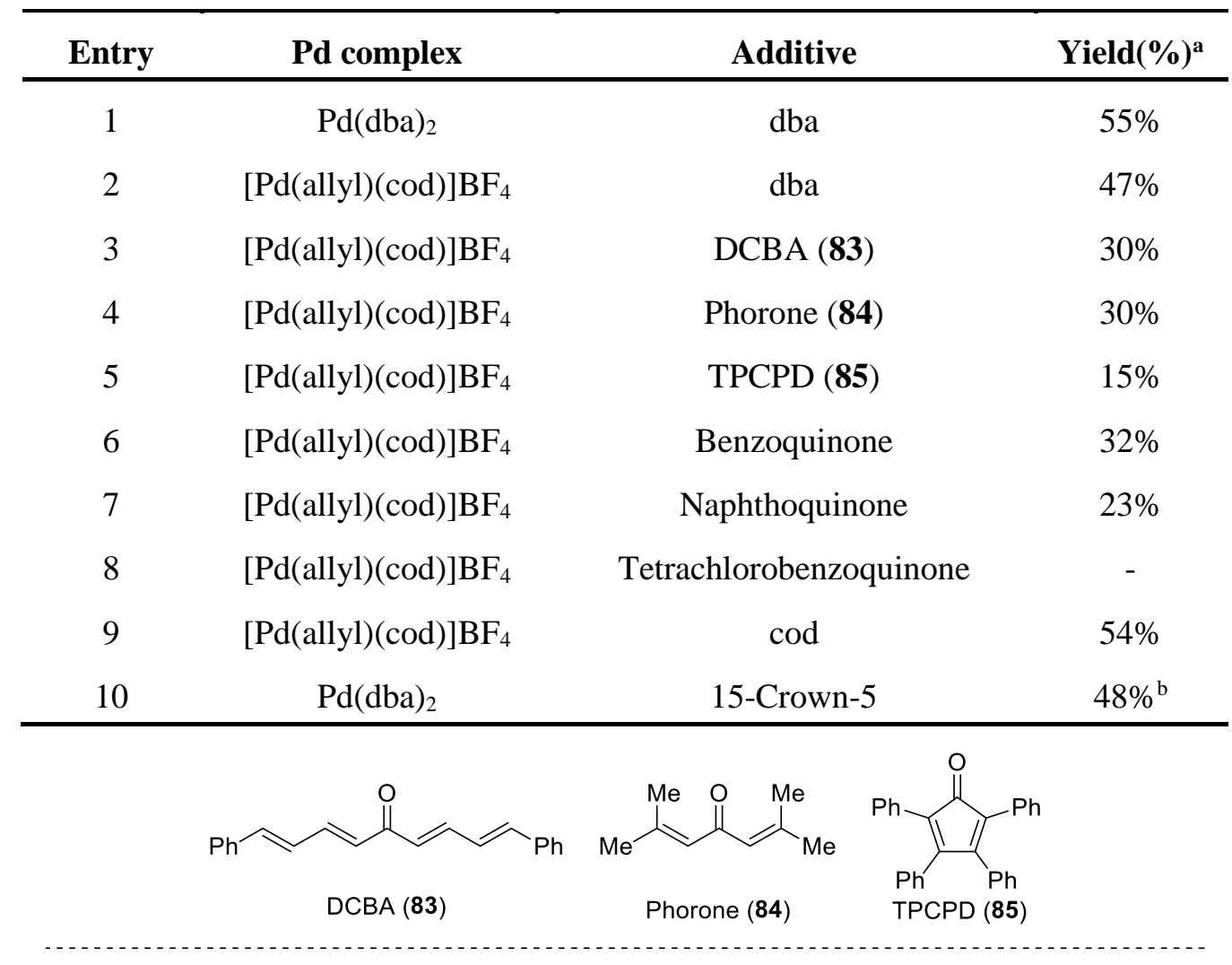

(a) Conditions: $0.15 \mathrm{mmol}$ 5a, $0.006 \mathrm{mmol}$ [Pd] (4 mol \%), $0.012 \mathrm{mmol}$ DPE-Phos ( $8 \mathrm{~mol} \%$ ), $0.225 \mathrm{mmol} 6 \mathbf{6 a}$ ( 1.5 equiv), $0.225 \mathrm{mmol}$ base (1.5 equiv), $0.06 \mathrm{mmol}$ additive ( 0.4 equiv), 0.8 $\mathrm{mL}$ toluene, $3 \mathrm{~h}, 80^{\circ} \mathrm{C}$, yield was determined by GC-MS; (b) $0.0060 \mathrm{mmol}$ DPE-Phos (4 mol $\%$ ); (b) 0.225 mmol 15-crown-5 (1.5 equiv).

Table S4. Screening of solvents, concentrations and palladium sources 


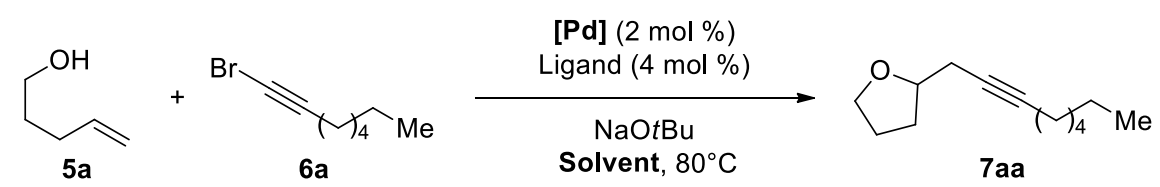

\begin{tabular}{|c|c|c|c|c|}
\hline Entry & Pd-catalyst & Solvent & Concentration & Yield $(\%)^{\mathrm{a}}$ \\
\hline 1 & $\operatorname{Pd}(\mathrm{dba})_{2}$ & $\mathrm{THF}$ & $0.19 \mathrm{M}$ & 8 \\
\hline 2 & $\operatorname{Pd}(d b a)_{2}$ & Dioxane & $0.19 \mathrm{M}$ & - \\
\hline 3 & $\operatorname{Pd}(d b a)_{2}$ & $\mathrm{CH}_{3} \mathrm{CN}$ & $0.19 \mathrm{M}$ & - \\
\hline 4 & $\operatorname{Pd}(d b a)_{2}$ & DMSO & $0.19 \mathrm{M}$ & - \\
\hline 5 & $\operatorname{Pd}(\mathrm{dba})_{2}$ & $\mathrm{DCE}$ & $0.19 \mathrm{M}$ & - \\
\hline 6 & $\operatorname{Pd}(\mathrm{dba})_{2}$ & Trifluoro toluene & $0.19 \mathrm{M}$ & 32 \\
\hline 7 & $\mathrm{Pd}(\mathrm{dba})_{2}$ & Xylene & $0.19 \mathrm{M}$ & 42 \\
\hline 8 & $\operatorname{Pd}(\mathrm{dba})_{2}$ & Toluene & $0.50 \mathrm{M}$ & 35 \\
\hline 9 & $\operatorname{Pd}(\mathrm{dba})_{2}$ & Toluene & $0.19 \mathrm{M}$ & 51 \\
\hline 10 & $\operatorname{Pd}(d b a)_{2}$ & Toluene & $0.075 \mathrm{M}$ & 65 \\
\hline 11 & $\operatorname{Pd}(\mathrm{dba})_{2}$ & Toluene & $0.019 \mathrm{M}$ & 62 \\
\hline 12 & $\operatorname{Pd}(\mathrm{dba})_{2}$ & Toluene & $0.19 \mathrm{M}$ & $61^{b}$ \\
\hline 13 & $\operatorname{Pd}(\mathrm{dba})_{2}$ & Toluene & $0.075 \mathrm{M}$ & $69^{c}$ \\
\hline 14 & $\operatorname{Pd}(\mathrm{dba})_{2}$ & Toluene & $0.075 \mathrm{M}$ & $72^{\mathrm{c}, \mathrm{d}}$ \\
\hline 15 & $\mathrm{Pd}_{2}(\mathrm{dba})_{3}$ & Toluene & $0.075 \mathrm{M}$ & $47^{\mathrm{c}}$ \\
\hline 16 & $\mathrm{Pd}_{2}(\mathrm{dba})_{3} \cdot \mathrm{CHCl}_{3}$ & Toluene & $0.075 \mathrm{M}$ & $39^{c}$ \\
\hline 17 & {$[\mathrm{Pd}($ cinnamyl $) \mathrm{Cp}]$} & Toluene & $0.075 \mathrm{M}$ & $51^{\mathrm{c}}$ \\
\hline
\end{tabular}

(a) Conditions: $0.15 \mathrm{mmol} 5 \mathrm{a}, 0.006 \mathrm{mmol}$ [Pd] (4 mol \%), $0.012 \mathrm{mmol}$ DPE-Phos ( $8 \mathrm{~mol} \%), 0.225 \mathrm{mmol}$ 6a ( 1.5 equiv), $0.225 \mathrm{mmol}$ base ( 1.5 equiv), $0.06 \mathrm{mmol}$ additive ( 0.4 equiv), $0.8 \mathrm{~mL}$ toluene, $3 \mathrm{~h}, 75-80^{\circ} \mathrm{C}$, yield was determined by GC-MS; (b) $0.0060 \mathrm{mmol}$ DPE-Phos (4 mol \%); (b) $0.012 \mathrm{mmol} \mathrm{Pd(dba)} 2$ (8 mol $\%$ ) and $0.024 \mathrm{mmol}$ DPE-Phos (16 mol \%); (c) $0.40 \mathrm{mmol}$ 5a, $0.020 \mathrm{mmol}$ [Pd] (5 mol \%), $0.030 \mathrm{mmol}$ ligand ( $7.5 \mathrm{~mol} \%), 0.52 \mathrm{mmol} 6 \mathbf{6 a}$ (1.3 equiv), $0.52 \mathrm{mmol} \mathrm{NaOtBu}$ (1.3 equiv), isolated yield determinded after column chromatography; (d) [Pd] 4 mol \%, DPE-Phos $16 \mathrm{~mol} \%$.

\section{Kinetic Datas:}

General procedure for standard conditions kinetic study: 
Under inert atmosphere, $\mathrm{Pd}(\mathrm{dba})_{2}(7.90 \mathrm{mg}, 0.0137 \mathrm{mmol}, 0.05$ equiv) and DPE-Phos (11.0 mg, $0.0205 \mathrm{mmol}, 0.075$ equiv) were introduced into a $2 \mathrm{~mL}$ vial, then $\mathrm{NatOBu}(36.9 \mathrm{mg}, 0.384$ mmol, 1.4 equiv) was introduced into another $2 \mathrm{~mL}$ vial and both vials were sealed. Degassed toluene was added into each vial $(2 \times 1.0 \mathrm{~mL})$. To the catalyst mixture was added alkynyl bromide (6h) (97.2 mg, $0.384 \mathrm{mmol}, 1.4$ equiv) followed by degassed toluene $(0.7 \mathrm{~mL})$. To the base solution was added 1-phenylpent-4-en-1-ol (5b) (44.5 mg, $0.274 \mathrm{mmol}, 1.0$ equiv) and the internal standard ( $n$-decane, $30 \mu \mathrm{L}, 0.16 \mathrm{mmol}$ ) followed by degassed toluene $(0.7 \mathrm{~mL})$. The vials were stirred at $80{ }^{\circ} \mathrm{C}$ for $5 \mathrm{~min}$ and then the $\mathrm{Na} t \mathrm{OBu}$-alcohol $\mathbf{5 b}$ solution was transferred via canula to the catalyst solution and samples were taken out at the indicated time and diluted with $\mathrm{CH}_{2} \mathrm{Cl}_{2}(1.0 \mathrm{~mL})$. The obtained solutions were injected into the GC-MS chromatographer (the following oven program was used: Initial temperature: $50{ }^{\circ} \mathrm{C}$, Ramp: $10.0{ }^{\circ} \mathrm{C} / \mathrm{min}$ to $250{ }^{\circ} \mathrm{C}$, hold $25 \mathrm{~min}$ at $250^{\circ} \mathrm{C}$ ). Yields were determined by GC-MS, based on the following calibrations.

\section{GC-MS Quantification:}

A $0.775 \mathrm{M}$ standard solution was prepared by dissolving $\mathrm{n}$-decane $(0.150 \mathrm{~mL}, 0.775 \mathrm{mmol})$ in $\mathrm{CH}_{2} \mathrm{Cl}_{2}(1.0 \mathrm{~mL})$.

1-Phenylpent-4-en-1-ol (5b) $(22.2 \mathrm{mg}, 0.137 \mathrm{mmol})$ was dissolved in $\mathrm{CH}_{2} \mathrm{Cl}_{2}(1.0 \mathrm{~mL})$ (solution $\mathrm{O})$.

- $25 \mu \mathrm{L}$ of solution $\mathrm{O}$ were mixed with $100 \mu \mathrm{L}$ of the standard solution $0.775 \mathrm{M}$ and diluted by adding $\mathrm{CH}_{2} \mathrm{Cl}_{2}(600 \mu \mathrm{L})$ to obtain solution $\mathrm{A}$;

- $33 \mu \mathrm{L}$ of solution $\mathrm{O}$ were mixed with $100 \mu \mathrm{L}$ of the standard solution $0.775 \mathrm{M}$ and diluted by adding $\mathrm{CH}_{2} \mathrm{Cl}_{2}(600 \mu \mathrm{L})$ to obtain solution $\mathrm{B}$;

- $50 \mu \mathrm{L}$ of solution $\mathrm{O}$ were mixed with $100 \mu \mathrm{L}$ of the standard solution $0.775 \mathrm{M}$ and diluted by adding $\mathrm{CH}_{2} \mathrm{Cl}_{2}(600 \mu \mathrm{L})$ to obtain solution $\mathrm{C}$;

- $75 \mu \mathrm{L}$ of solution $\mathrm{O}$ were mixed with $100 \mu \mathrm{L}$ of the standard solution $0.775 \mathrm{M}$ and diluted by adding $\mathrm{CH}_{2} \mathrm{Cl}_{2}(600 \mu \mathrm{L})$ to obtain solution $\mathrm{D}$;

- $100 \mu \mathrm{L}$ of solution $\mathrm{O}$ were mixed with $100 \mu \mathrm{L}$ of the standard solution $0.775 \mathrm{M}$ and diluted by adding $\mathrm{CH}_{2} \mathrm{Cl}_{2}(600 \mu \mathrm{L})$ to obtain solution $\mathrm{E}$;

GC-MS chromatograms were acquired for solutions A, B, C, D and E and in each of them the ratio between the integrals of the signals corresponding to compound $\mathbf{5 b}$ (retention time: 14.0 min) and to the internal standard (retention time: $8.50 \mathrm{~min}$ ) was calculated. These observed ratios by integration of the chromatogram peaks and the ratios ( $\mathrm{mmol} \mathbf{5 b} / \mathbf{m m o l ~ n - d e c a n e ) ~ w e r e ~ u s e d ~ a s ~}$ the axis of the calibration graph. 


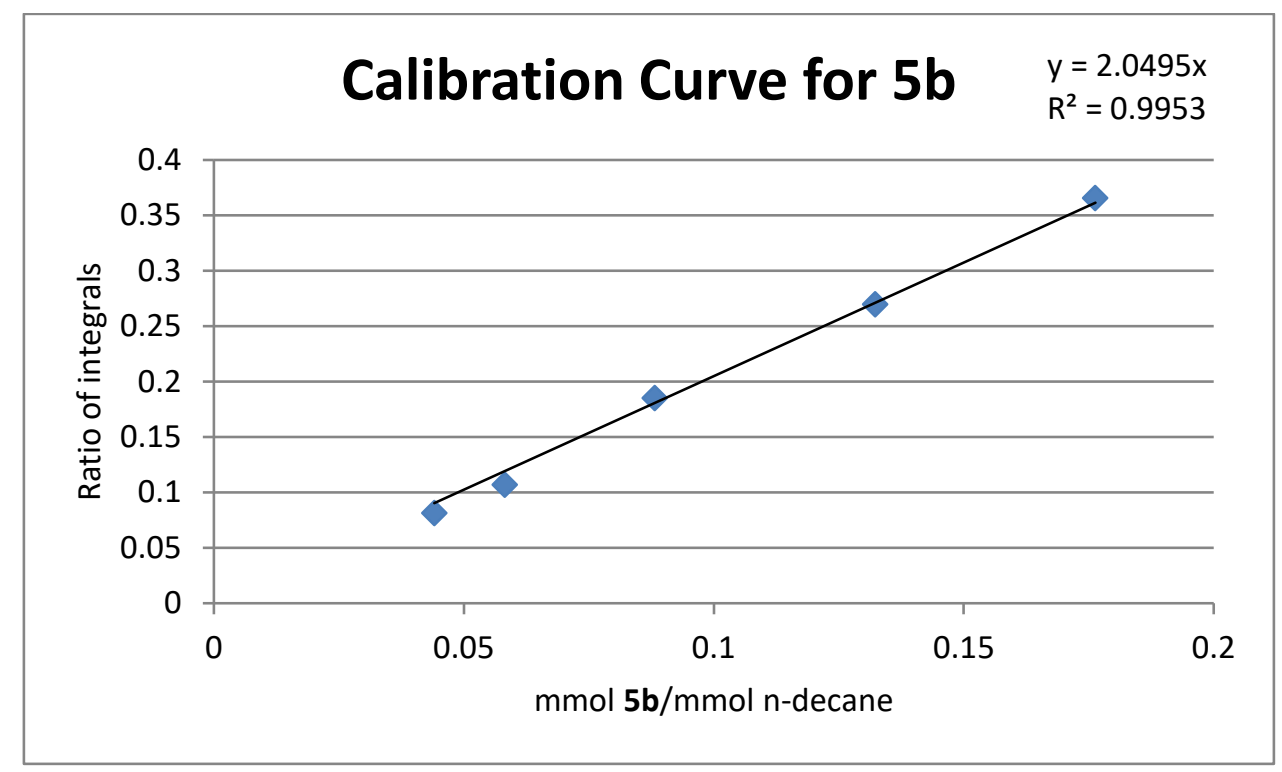

Alkynyl bromide $6 \mathbf{h}$ (49.4 mg, $0.195 \mathrm{mmol}$ ) was dissolved in $\mathrm{CH}_{2} \mathrm{Cl}_{2}$ (1.0 mL) (solution P).

- $25 \mu \mathrm{L}$ of solution $\mathrm{P}$ were mixed with $100 \mu \mathrm{L}$ of the standard solution $0.775 \mathrm{M}$ and diluted by adding $\mathrm{CH}_{2} \mathrm{Cl}_{2}(600 \mu \mathrm{L})$ to obtain solution $\mathrm{A}$;

- $33 \mu \mathrm{L}$ of solution $\mathrm{P}$ were mixed with $100 \mu \mathrm{L}$ of the standard solution $0.775 \mathrm{M}$ and diluted by adding $\mathrm{CH}_{2} \mathrm{Cl}_{2}(600 \mu \mathrm{L})$ to obtain solution $\mathrm{B}$;

- $50 \mu \mathrm{L}$ of solution $\mathrm{P}$ were mixed with $100 \mu \mathrm{L}$ of the standard solution $0.775 \mathrm{M}$ and diluted by adding $\mathrm{CH}_{2} \mathrm{Cl}_{2}(600 \mu \mathrm{L})$ to obtain solution $\mathrm{C}$;

- $75 \mu \mathrm{L}$ of solution $\mathrm{P}$ were mixed with $100 \mu \mathrm{L}$ of the standard solution $0.775 \mathrm{M}$ and diluted by adding $\mathrm{CH}_{2} \mathrm{Cl}_{2}(600 \mu \mathrm{L})$ to obtain solution $\mathrm{D}$;

- $100 \mu \mathrm{L}$ of solution $\mathrm{P}$ were mixed with $100 \mu \mathrm{L}$ of the standard solution $0.775 \mathrm{M}$ and diluted by adding $\mathrm{CH}_{2} \mathrm{Cl}_{2}(600 \mu \mathrm{L})$ to obtain solution $\mathrm{E}$;

GC-MS chromatograms were acquired for solutions A, B, C, D and E and in each of them the ratio between the integrals of the signals corresponding to compound $\mathbf{6 h}$ (retention time: 15.95 $\mathrm{min}$ ) and to the internal standard (retention time: $8.50 \mathrm{~min}$ ) was calculated. These observed ratios by integration of the chromatogram peaks and the ratios ( $\mathrm{mmol} \mathbf{6 h} / \mathrm{mmol} \mathrm{n}$-decane) were used as the axis of the calibration graph. 


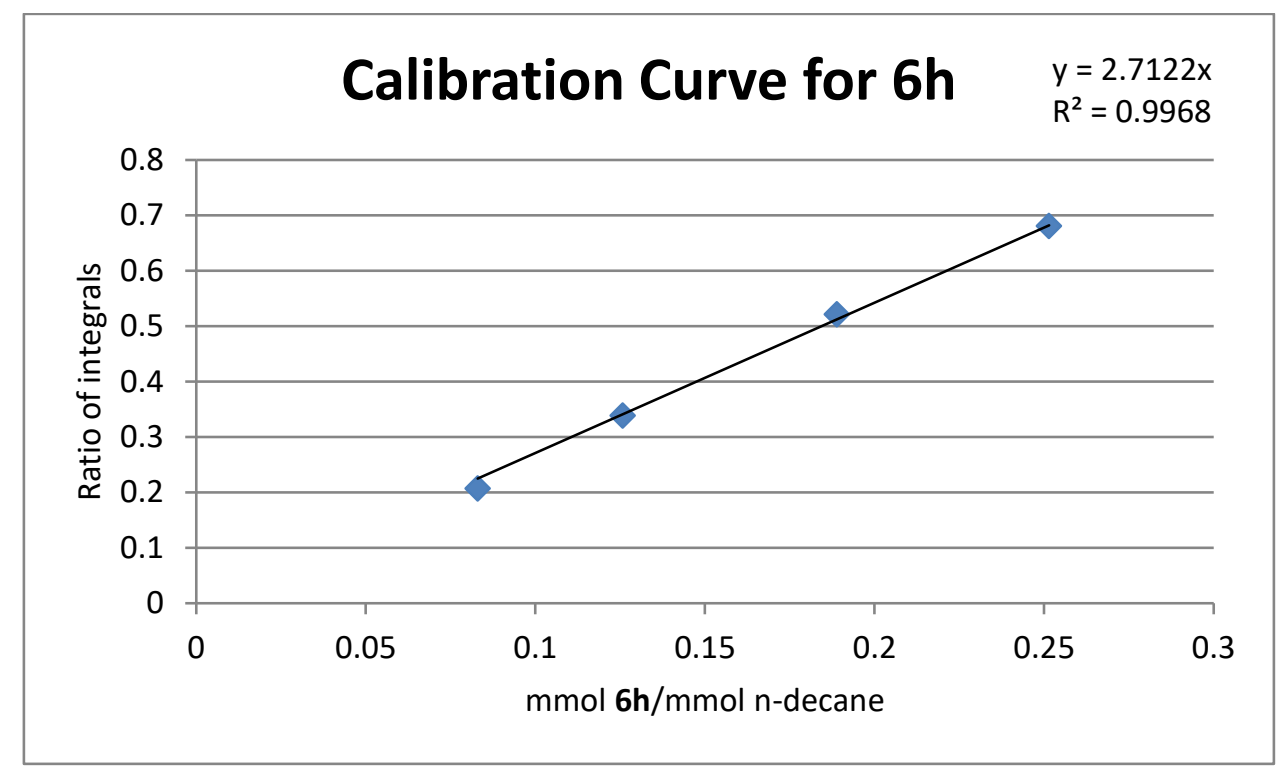

Oxyalkynylation product $7 \mathbf{b h}(45.8 \mathrm{mg}, 0.137 \mathrm{mmol})$ was dissolved in $\mathrm{CH}_{2} \mathrm{Cl}_{2}(1.0 \mathrm{~mL})$ (solution Q).

- $25 \mu \mathrm{L}$ of solution $\mathrm{Q}$ were mixed with $100 \mu \mathrm{L}$ of the standard solution $0.775 \mathrm{M}$ and diluted by adding $\mathrm{CH}_{2} \mathrm{Cl}_{2}(600 \mu \mathrm{L})$ to obtain solution $\mathrm{A}$;

- $33 \mu \mathrm{L}$ of solution $\mathrm{Q}$ were mixed with $100 \mu \mathrm{L}$ of the standard solution $0.775 \mathrm{M}$ and diluted by adding $\mathrm{CH}_{2} \mathrm{Cl}_{2}(600 \mu \mathrm{L})$ to obtain solution $\mathrm{B}$;

- $50 \mu \mathrm{L}$ of solution $\mathrm{Q}$ were mixed with $100 \mu \mathrm{L}$ of the standard solution $0.775 \mathrm{M}$ and diluted by adding $\mathrm{CH}_{2} \mathrm{Cl}_{2}(600 \mu \mathrm{L})$ to obtain solution $\mathrm{C}$;

- $75 \mu \mathrm{L}$ of solution $\mathrm{Q}$ were mixed with $100 \mu \mathrm{L}$ of the standard solution $0.775 \mathrm{M}$ and diluted by adding $\mathrm{CH}_{2} \mathrm{Cl}_{2}(600 \mu \mathrm{L})$ to obtain solution $\mathrm{D}$;

- $100 \mu \mathrm{L}$ of solution Q were mixed with $100 \mu \mathrm{L}$ of the standard solution $0.775 \mathrm{M}$ and diluted by adding $\mathrm{CH}_{2} \mathrm{Cl}_{2}(600 \mu \mathrm{L})$ to obtain solution $\mathrm{E}$;

GC-MS chromatograms were acquired for solutions A, B, C, D and E and in each of them the ratio between the integrals of the signals corresponding to compound $\mathbf{7 b h}$ (retention time: 36.38 $\mathrm{min}$ ) and to the internal standard (retention time: $8.50 \mathrm{~min}$ ) was calculated. These observed ratios by integration of the chromatogram peaks and the ratios ( $\mathrm{mmol} \mathbf{7 b h} / \mathrm{mmol} \mathrm{n}$-decane) were used as the axis of the calibration graph. The data corresponding to solution A was discarded in order to get a better accuracy. 


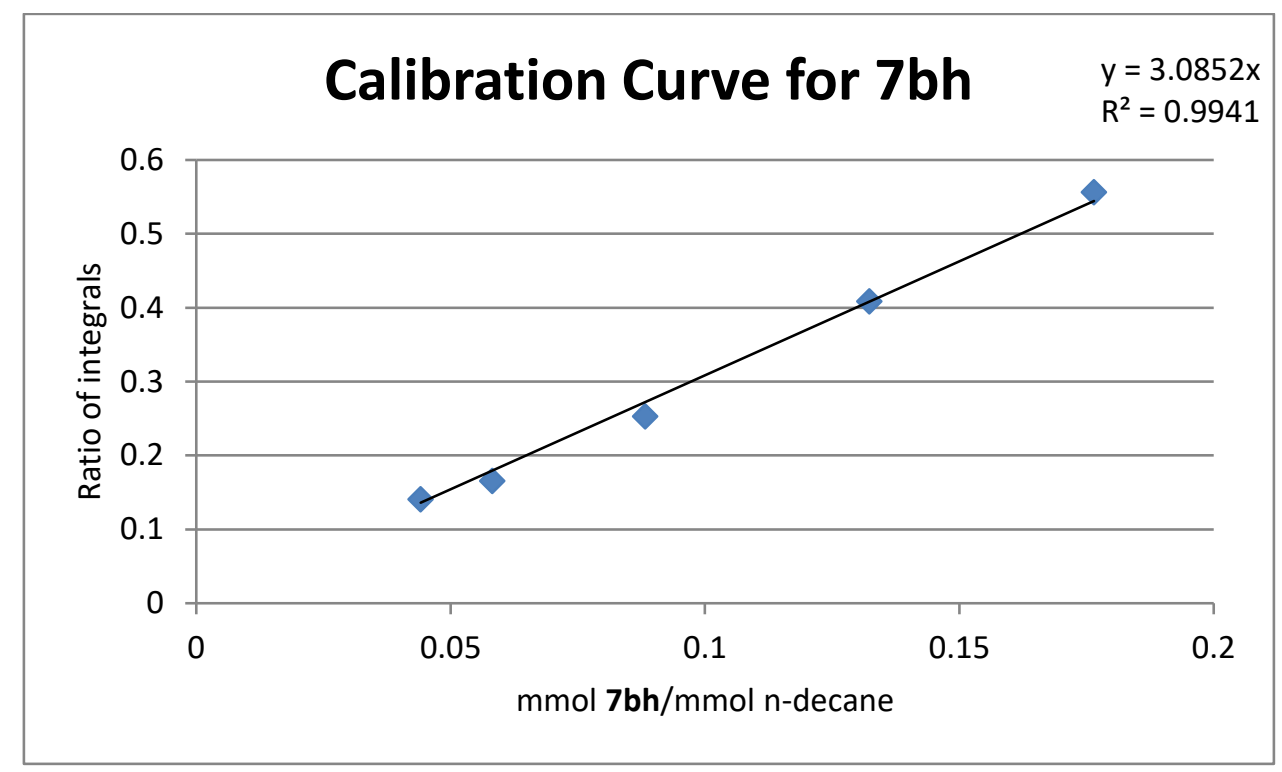

\section{Stoichiometric Calculations for product $7 \mathrm{bh}$ formation:}

The reagent stoichiometry kinetic study was performed following the general procedure for the standard conditions with the amount of reagents described in table S5. The data for the reagent stoichiometry effect on the rate of formation of $\mathbf{7 b h}$ are shown in tables S6-S10. The concentrations (in mmol) for the formation of $\mathbf{7 b h}$ were calculated using the equation of the corresponding calibration curve (Calibration Curve for $\mathbf{7 b h}$ ). The standard deviations were calculated using the following equation:

$$
s=\sqrt{\frac{1}{n} \sum_{i=1}^{n}\left(x_{i}-\bar{x}\right)^{2}}, n=3
$$

Table S5: Reagent stoichiometry conditions.

\begin{tabular}{cccccc}
\hline Entry & $\mathbf{5 b}[\mathbf{m m o l}]$ & $\mathbf{6 h}[\mathbf{m m o l}]$ & $\begin{array}{c}\text { Pd(dba) } \\
{[\mathbf{m m o l}]}\end{array}$ & $\begin{array}{c}\text { DPE-Phos } \\
{[\mathbf{m m o l}]}\end{array}$ & $\begin{array}{c}\text { NatOBu } \\
{[\mathbf{m m o l}]}\end{array}$ \\
\hline 1 & 0.547 & 0.384 & 0.0137 & 0.0205 & 0.384 \\
2 & 0.274 & 0.768 & 0.0137 & 0.0205 & 0.384 \\
3 & 0.274 & 0.384 & 0.0274 & 0.0410 & 0.384 \\
4 & 0.274 & 0.384 & 0.0137 & 0.0205 & 0.768 \\
\hline
\end{tabular}


Table S6: Rate of formation of 7bh using conditions of Entry 1, Table S5.

\begin{tabular}{cccccc}
\hline Time [min] & $\begin{array}{c}\text { Exp. 1 :mmol } \\
\text { of 7bh }\end{array}$ & $\begin{array}{c}\text { Exp. 2 :mmol } \\
\text { of 7 } \mathbf{b h}\end{array}$ & $\begin{array}{c}\text { Exp. 3 :mmol } \\
\text { of } \mathbf{7 b h}\end{array}$ & $\begin{array}{c}\text { Average: } \\
\text { mmol of } \mathbf{7 b h}\end{array}$ & $\begin{array}{c}\text { Standard } \\
\text { Deviation }\end{array}$ \\
\hline 0 & 0 & 0 & 0 & 0 & 0 \\
2 & 0.00592 & 0.00406 & 0.004622 & 0.00445 & 0.000278 \\
4 & 0.00870 & 0.0186 & 0.00554 & 0.00595 & 0.000306 \\
6 & 0.0119 & 0.00628 & 0.00763 & 0.00769 & 0.000221 \\
8 & 0.0148 & 0.00746 & 0.00860 & 0.00907 & 0.000716 \\
10 & 0.0171 & 0.00854 & 0.00930 & 0.00994 & 0.000452 \\
12 & 0.0210 & 0.0103 & 0.0130 & 0.0120 & 0.000914 \\
15 & 0.0227 & 0.0108 & 0.0126 & 0.0132 & 0.000629 \\
18 & 0.0251 & 0.0141 & 0.0136 & 0.0149 & 0.00105 \\
21 & 0.0327 & 0.0161 & 0.0147 & 0.0159 & 0.000827 \\
31 & 0.0366 & 0.0164 & 0.0166 & 0.0181 & 0.00148 \\
41 & 0.0416 & 0.0175 & 0.0168 & 0.0192 & 0.00221 \\
51 & 0.0505 & 0.0187 & 0.0170 & 0.0195 & 0.00186 \\
61 & 0.0557 & 0.0201 & 0.0167 & 0.0196 & 0.00300 \\
76 & 0.0553 & 0.0182 & 0.0173 & 0.0203 & 0.00332 \\
\hline
\end{tabular}

Table S7: Rate of formation of 7bh using conditions of Entry 2, Table S5.

\begin{tabular}{cccccc}
\hline Time [min] & $\begin{array}{c}\text { Exp. 1 :mmol } \\
\text { of 7 bh }\end{array}$ & $\begin{array}{c}\text { Exp. 2 :mmol } \\
\text { of 7 bh }\end{array}$ & $\begin{array}{c}\text { Exp. 3 :mmol } \\
\text { of 7 } \mathbf{b h}\end{array}$ & $\begin{array}{c}\text { Average: } \\
\text { mmol of 7bh }\end{array}$ & $\begin{array}{c}\text { Standard } \\
\text { Deviation }\end{array}$ \\
\hline 0 & 0 & 0 & 0 & 0 & 0 \\
2 & 0.00420 & 0.00247 & 0.00395 & 0.00354 & 0.000761 \\
4 & 0.00568 & 0.00506 & 0.00631 & 0.00568 & 0.000511 \\
6 & 0.00816 & 0.00666 & 0.00822 & 0.00768 & 0.000721 \\
8 & 0.0103 & 0.00820 & 0.00977 & 0.00942 & 0.000886 \\
10 & 0.0121 & 0.0108 & 0.0108 & 0.0112 & 0.000600 \\
12 & 0.0133 & 0.0114 & 0.0121 & 0.0122 & 0.000819 \\
15 & 0.0161 & 0.0141 & 0.0132 & 0.0145 & 0.00122 \\
18 & 0.0167 & 0.0156 & 0.0147 & 0.0157 & 0.000827 \\
21 & 0.0196 & 0.0162 & 0.0162 & 0.0173 & 0.00161 \\
31 & 0.0247 & 0.0220 & 0.0190 & 0.0219 & 0.00232 \\
41 & 0.0328 & 0.0286 & 0.0218 & 0.0277 & 0.00453 \\
51 & 0.0348 & 0.0263 & 0.0240 & 0.0283 & 0.00465 \\
61 & 0.0393 & 0.0254 & 0.0215 & 0.0287 & 0.00763 \\
76 & 0.0371 & 0.0248 & 0.0211 & 0.0277 & 0.00683 \\
\hline
\end{tabular}


Table S8: Rate of formation of $7 \mathbf{b h}$ using conditions of Entry 3, Table S5.

\begin{tabular}{cccccc}
\hline Time [min] & $\begin{array}{c}\text { Exp. 1 :mmol } \\
\text { of 7 bh }\end{array}$ & $\begin{array}{c}\text { Exp. 2 :mmol } \\
\text { of 7 bh }\end{array}$ & $\begin{array}{c}\text { Exp. 3 :mmol } \\
\text { of 7bh }\end{array}$ & $\begin{array}{c}\text { Average: } \\
\text { mmol of 7bh }\end{array}$ & $\begin{array}{c}\text { Standard } \\
\text { Deviation }\end{array}$ \\
\hline 0 & 0 & 0 & 0 & 0 & 0 \\
2 & 0.00488 & 0.00844 & 0.00643 & 0.00658 & 0.00146 \\
4 & 0.00961 & 0.0124 & 0.0101 & 0.0107 & 0.00120 \\
6 & 0.0101 & 0.0168 & 0.0135 & 0.0135 & 0.00270 \\
8 & 0.0172 & 0.0237 & 0.0165 & 0.0191 & 0.00323 \\
10 & 0.0213 & 0.0255 & 0.0197 & 0.0221 & 0.00247 \\
12 & 0.0236 & 0.0289 & 0.0235 & 0.0254 & 0.00252 \\
15 & 0.0269 & 0.0377 & 0.0282 & 0.0309 & 0.00483 \\
18 & 0.0312 & 0.0438 & 0.0302 & 0.0351 & 0.00621 \\
21 & 0.0344 & 0.0438 & 0.0341 & 0.0374 & 0.00449 \\
31 & 0.0400 & 0.0458 & 0.0356 & 0.0405 & 0.00419 \\
41 & 0.0431 & 0.0487 & 0.0371 & 0.0430 & 0.00476 \\
51 & 0.0419 & 0.0459 & 0.0387 & 0.0421 & 0.00294 \\
61 & 0.0398 & 0.0526 & 0.0362 & 0.0429 & 0.00703 \\
76 & 0.0403 & 0.0443 & 0.0343 & 0.0396 & 0.00413 \\
\hline
\end{tabular}

Table S9: Rate of formation of 7bh using conditions of Entry 4, Table S5.

\begin{tabular}{cc}
\hline Time [min] & mmol of $7 \mathbf{b h}$ \\
\hline 0 & 0 \\
2 & 0.00164 \\
4 & 0.00162 \\
6 & 0.00157 \\
8 & 0.00207 \\
10 & 0.00206 \\
12 & 0.00210 \\
15 & 0.00250 \\
18 & 0.00239 \\
21 & 0.00307 \\
31 & 0.00344 \\
41 & 0.00397 \\
51 & 0.00425 \\
61 & 0.00447 \\
76 & 0.00451 \\
\hline
\end{tabular}


Table S10: Rate of formation of $\mathbf{7 b h}$ using the standard conditions described in the general procedure.

\begin{tabular}{cccccc}
\hline Time [min] & $\begin{array}{c}\text { Exp. 1 :mmol } \\
\text { of 7 bh }\end{array}$ & $\begin{array}{c}\text { Exp. 2 :mmol } \\
\text { of 7 bh }\end{array}$ & $\begin{array}{c}\text { Exp. 3 :mmol } \\
\text { of 7bh }\end{array}$ & $\begin{array}{c}\text { Average: } \\
\text { mmol of 7bh }\end{array}$ & $\begin{array}{c}\text { Standard } \\
\text { Deviation }\end{array}$ \\
\hline 0 & 0 & 0 & 0 & 0 & 0 \\
2 & 0.00104 & 0.00249 & 0.00294 & 0.00216 & 0.000809 \\
4 & 0.00331 & 0.00376 & 0.00383 & 0.00363 & 0.000229 \\
6 & 0.00461 & 0.00588 & 0.00580 & 0.00543 & 0.000579 \\
8 & 0.00592 & 0.00684 & 0.00744 & 0.00673 & 0.000621 \\
10 & 0.00756 & 0.00822 & 0.00907 & 0.00828 & 0.000621 \\
12 & 0.00850 & 0.00999 & 0.0102 & 0.00957 & 0.000762 \\
15 & 0.0102 & 0.0113 & 0.0137 & 0.0117 & 0.00148 \\
18 & 0.0116 & 0.0133 & 0.0149 & 0.0133 & 0.00136 \\
21 & 0.0130 & 0.0165 & 0.0168 & 0.0154 & 0.00173 \\
31 & 0.0165 & 0.0217 & 0.0238 & 0.0207 & 0.00306 \\
41 & 0.0196 & 0.0259 & 0.0260 & 0.0238 & 0.00296 \\
51 & 0.0215 & 0.0287 & 0.0294 & 0.0265 & 0.00358 \\
61 & 0.0239 & 0.0286 & 0.0311 & 0.0279 & 0.00297 \\
76 & 0.0263 & 0.0304 & 0.0298 & 0.0288 & 0.00179 \\
\hline
\end{tabular}

\section{Crude analysis of the initial rate of the product formation :}

The initial rate of the product formation was determined by a linear fitting of the four first points of tables S6, S7, S8 and S10. The slope of the linear regression gave the following initial rates:

Table S11: Initial rate of formation of $7 \mathrm{bh}$.

\begin{tabular}{|l|c|c|c|c|}
\hline & Table S6 & Table S7 & Table S8 & Table S10 \\
\hline Initial rate $\left[\mathbf{m i n}^{-\mathbf{1}} \cdot \boldsymbol{c}_{\boldsymbol{i}}^{\mathbf{1 - \boldsymbol { n } _ { \boldsymbol { i } }}}\right]$ & 0.00141 & 0.00136 & 0.00244 & 0.000918 \\
\hline
\end{tabular}

Knowing the initial rates (Table S11) and the initial concentrations (Table S12) the orders were calculated using the following general equations and the van't Hoff plot (log (initial rate) as a function of $\log$ (initial concentration)) by comparing the data of each reagent specie with the standard conditions:

$$
\begin{gathered}
v=k \prod_{i=1}^{r} c_{i}^{n_{i}} \text { and } n:=\sum_{i=1}^{r} n_{i}=(\text { overall) order of a reaction } \\
r=\text { number of reactants, } c_{i}=\text { concentration of reactant } i
\end{gathered}
$$

Table S12: Initial concentrations and orders of the reagent species.

\begin{tabular}{cccc}
\hline Reagent & $\begin{array}{c}\text { Initial Concentration } \\
\text { (Table 1) [mmol] }\end{array}$ & $\begin{array}{c}\text { Initial Concentration } \\
\text { (standard conditions) } \\
\text { [mmol] }\end{array}$ & Order $\boldsymbol{n}_{\boldsymbol{i}}$ \\
\hline $\mathbf{5 b}$ & 0.547 & 0.274 & 0.6 \\
$\mathbf{6 h}$ & 0.768 & 0.384 & 0.6 \\
$\mathbf{P d}(\mathbf{d b a})_{\mathbf{2}}$ & 0.0410 & 0.0205 & 1.4 \\
\hline
\end{tabular}


In the case of the base, the initial rate was not determined as no linear fitting was possible due to the base mediated inhibition of the reaction.

\section{Spectra of New Compounds}




\section{Tetradec-1-en-7-yn-5-ol (5c)}

Solvent: $C D C 13$
Frequency. 400.13
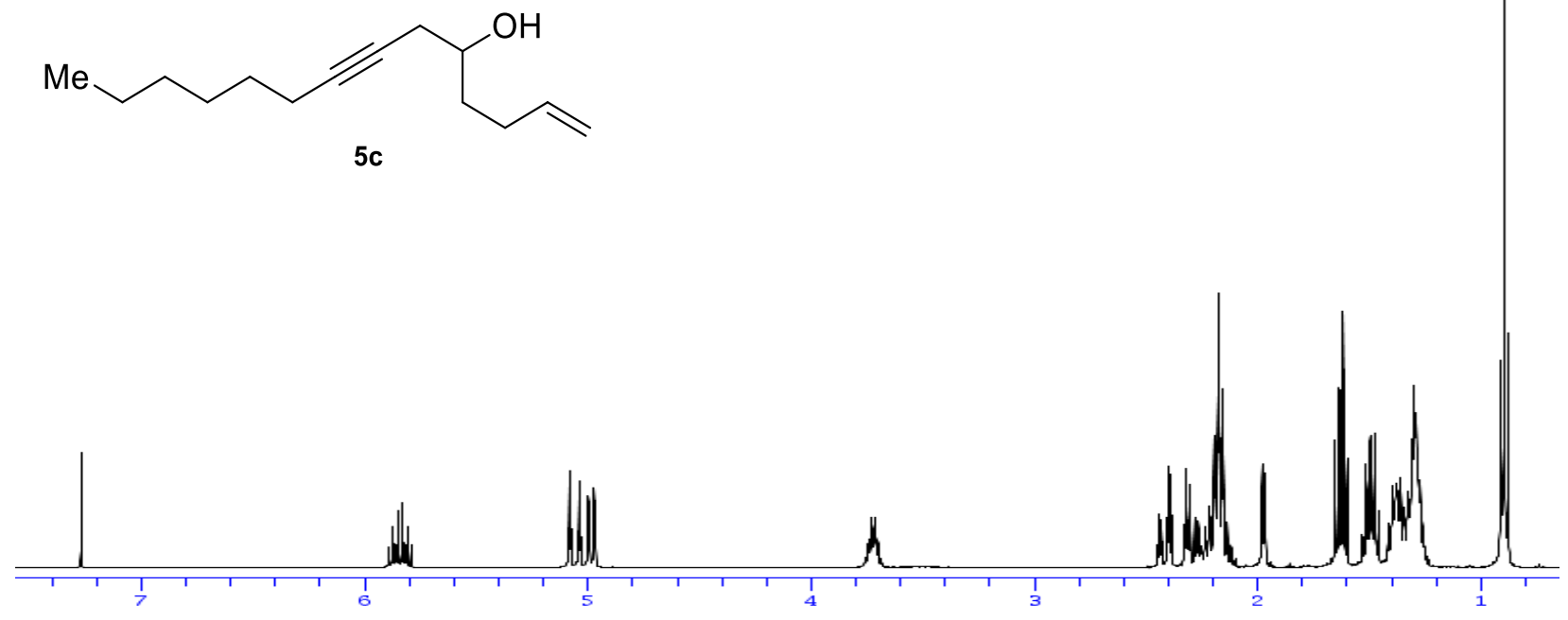

Solvent: $C D C 13$

Frequency.100.61
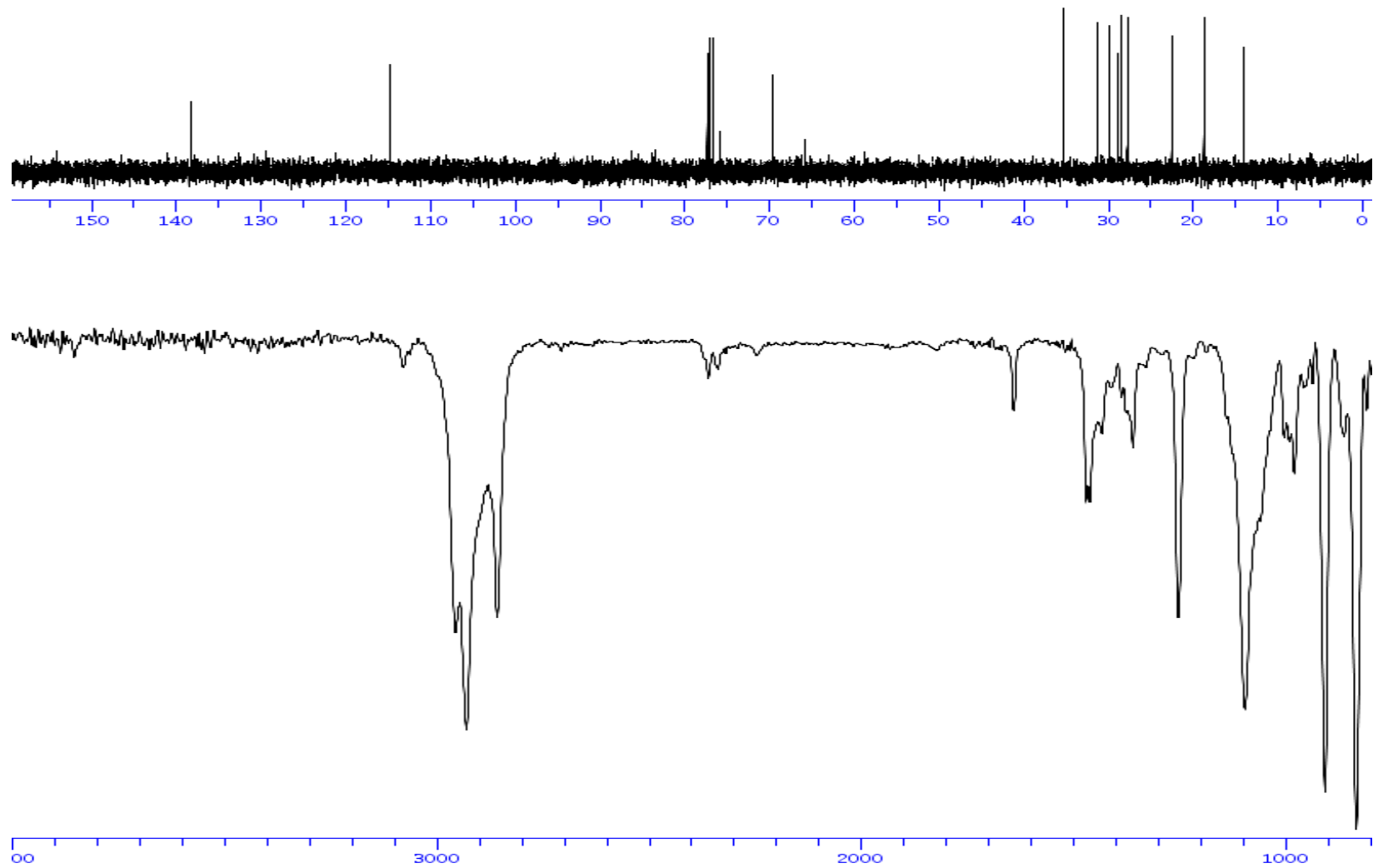

oo

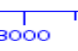


((5-Bromopent-4-yn-1-yl)oxy)(tert-butyl)diphenylsilane (6d)

Solvent: $C D C 13$
Frequency.400.11MHz

$\mathrm{Br}$

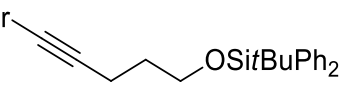

$6 d$

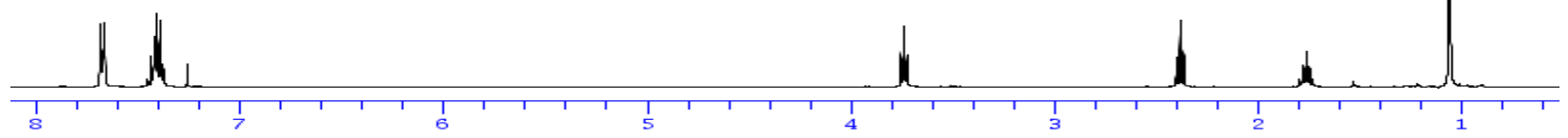

Solvent: $\mathrm{CDCl} 3$

$.61 \mathrm{MHz}$

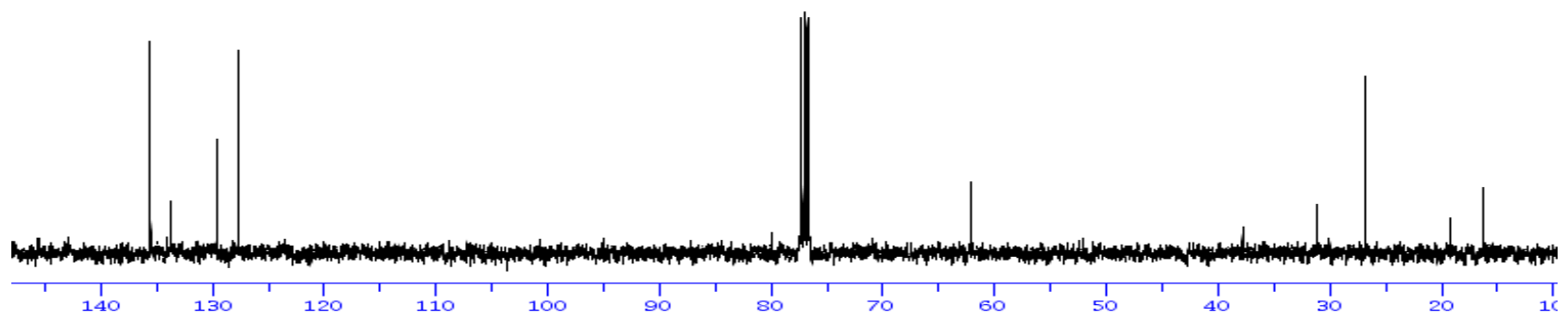

\}

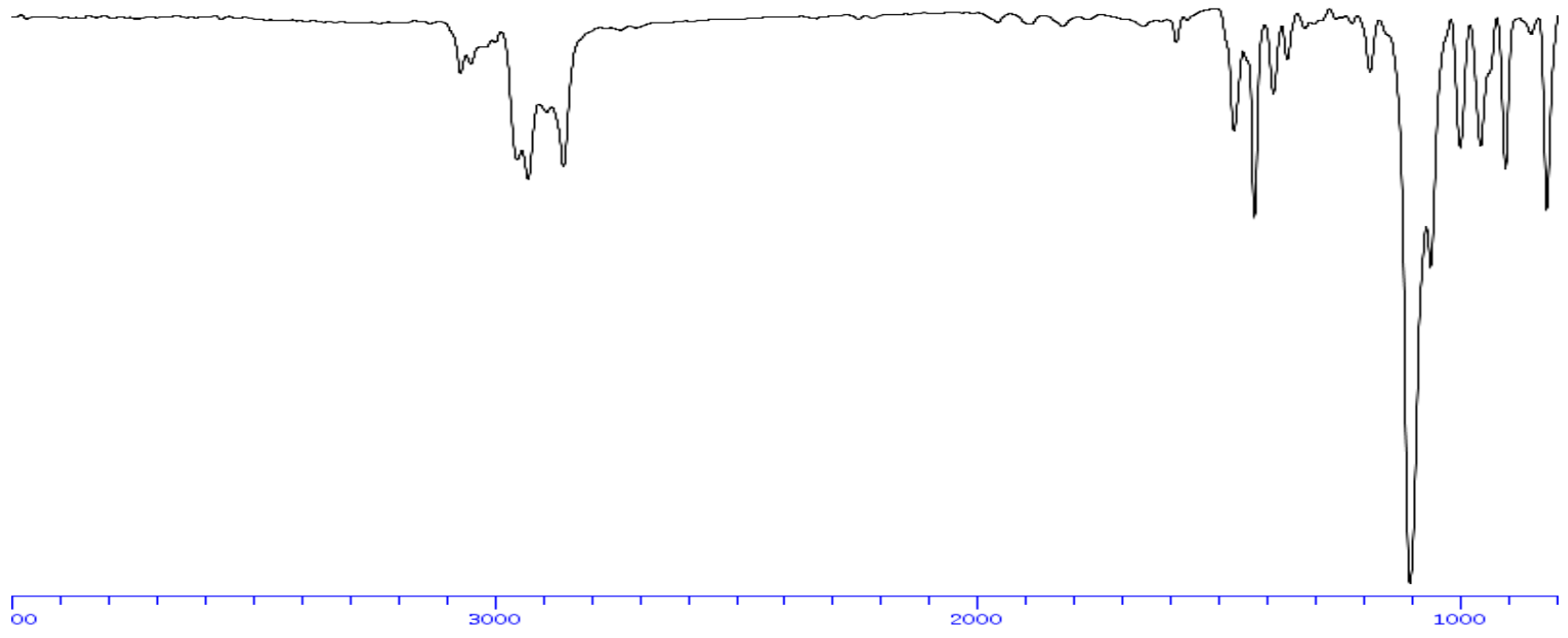


1-Bromo-5-chloropent-1-yne (6f)

Solvent: $\mathrm{CDCl} 3$

Frequency. $400.13 \mathrm{MHz}$

$\mathrm{Br}$<smiles>ClCCCC#C[Te]</smiles>

$6 f$

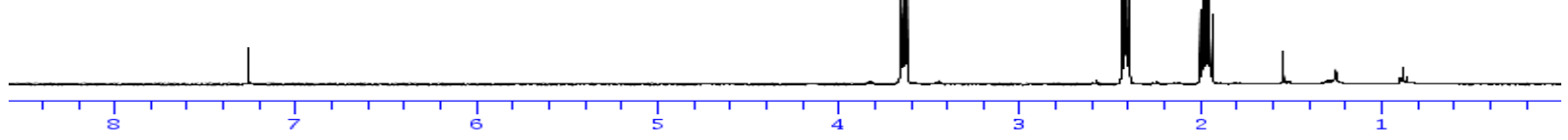

Solvent: $\mathrm{CDCl} 3$

Frequency.100.61MHz
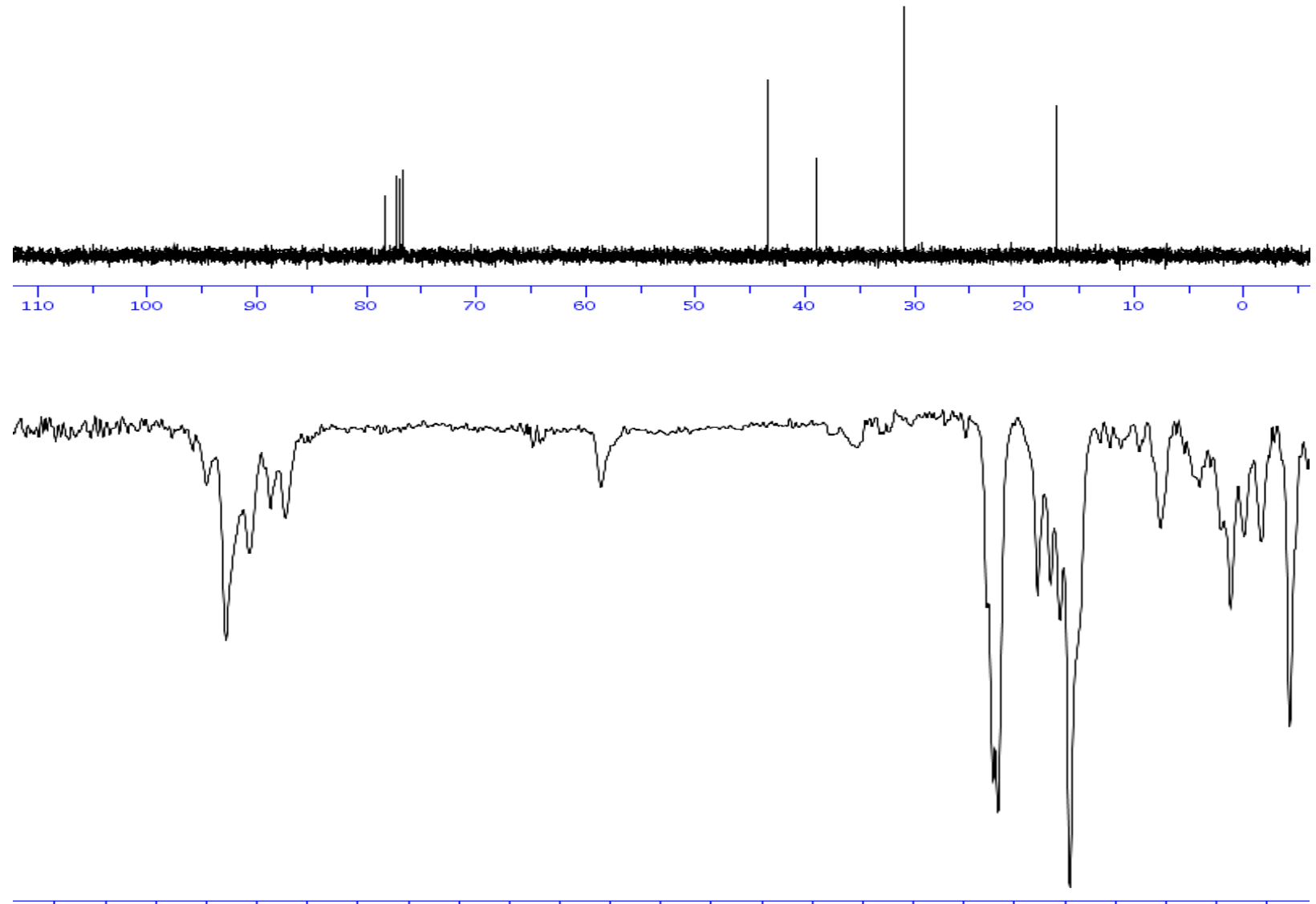
(7-Bromohepta-1,6-diyn-1-yl)triisopropylsilane (6g)

Solvent: $C D C I 3$
Frequency. $400.11 \mathrm{MHz}$

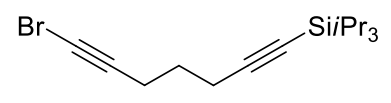

$6 \mathrm{~g}$

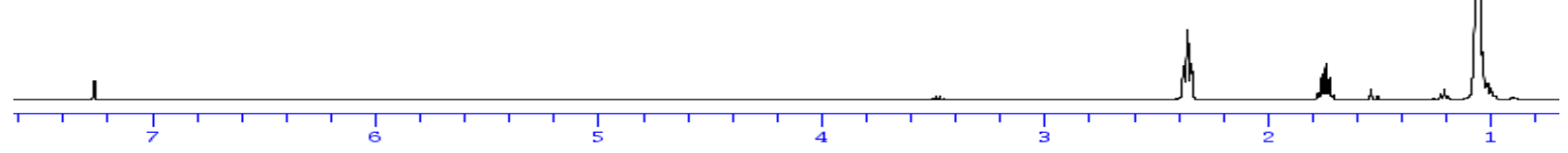

Solvent: $C D C I 3$

quency. $100.61 \mathrm{MHz}$
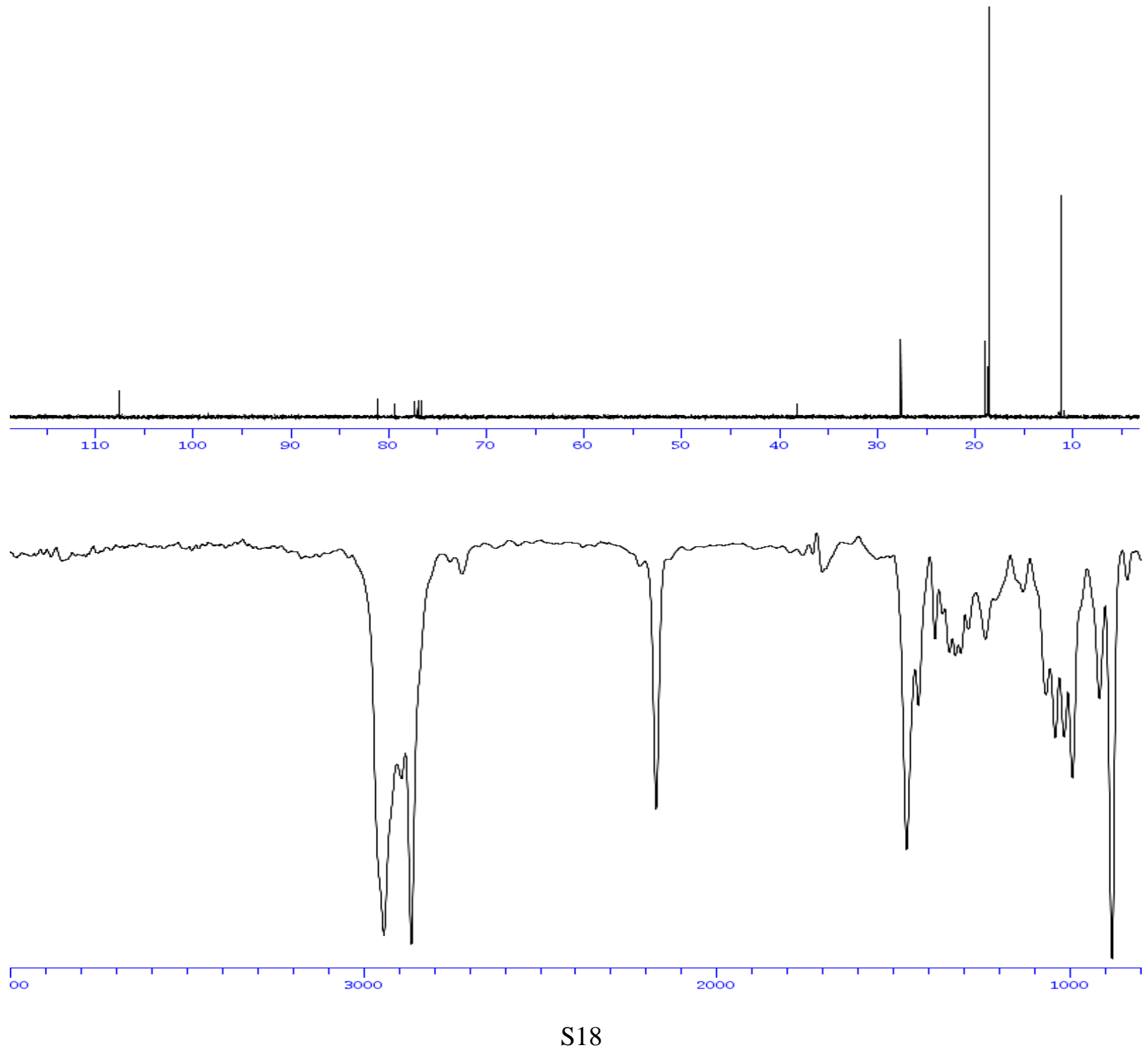
(((4-Bromo-2-methylbut-3-yn-2-yl)oxy)methyl)benzene (6h)

Solvent: $\mathrm{CDC13}$

Frequency. 400.11MHz
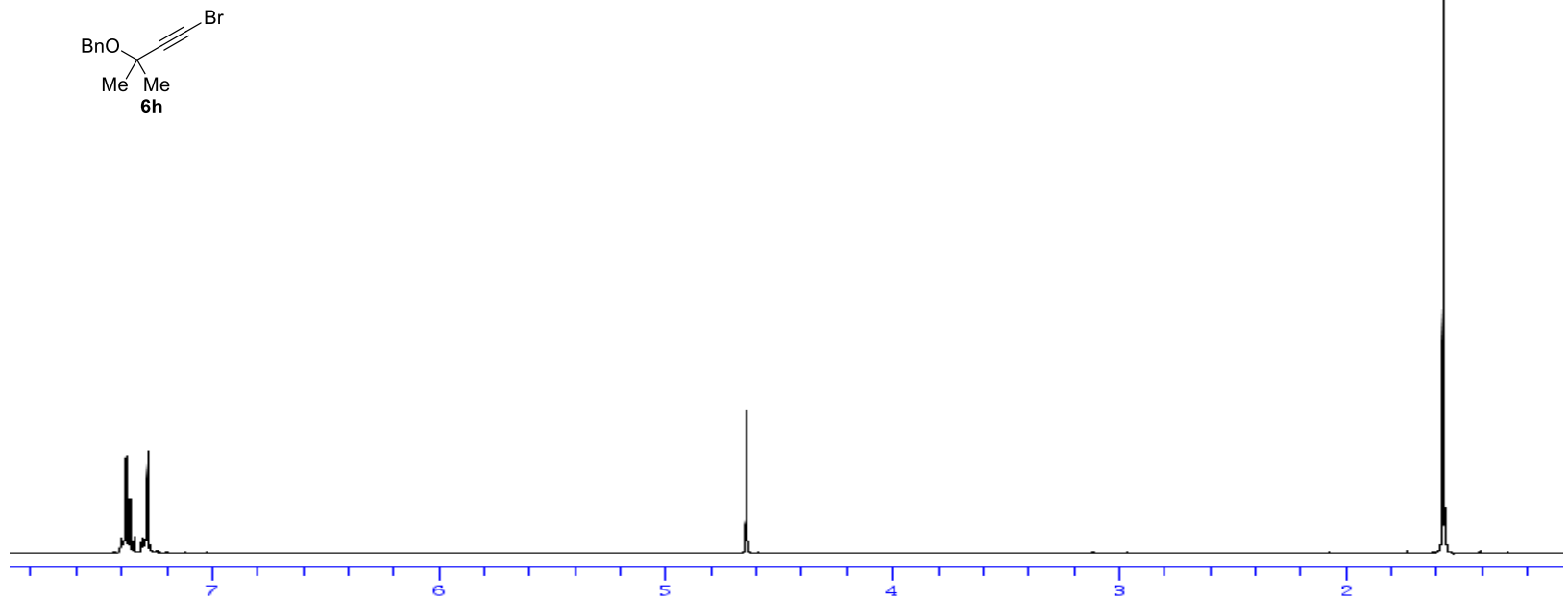

Solvent: $\mathrm{CDCI} 3$

. $10 \mathrm{MHz}$
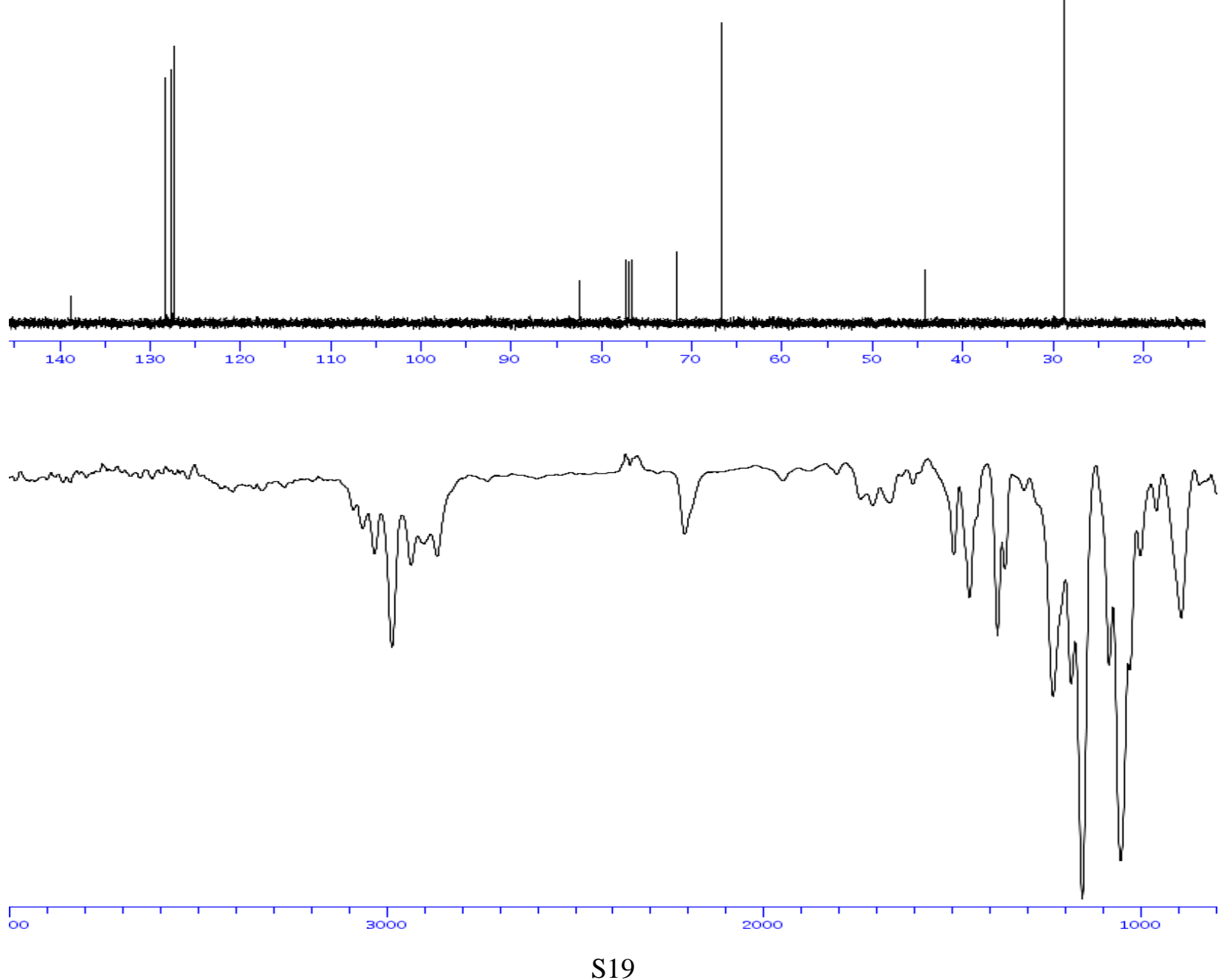
((4-bromo-2-methylbut-3-yn-2-yl)oxy)triisopropylsilane (6i)

Solvent: $\mathrm{CDC13}$

Frequency. $400.13 \mathrm{MHz}$

$\mathrm{Br}$<smiles>CC#CC(C)(C)O[GaH2]</smiles>

$6 \mathrm{i}$

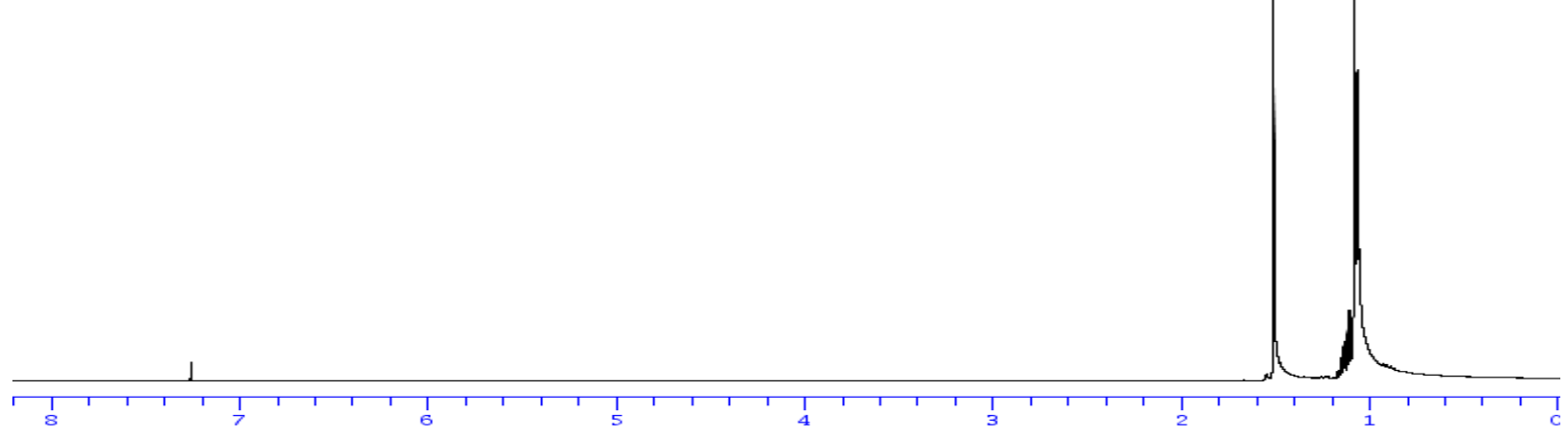

Solvent: $C D C I 3$

Frequency.100.61MHz
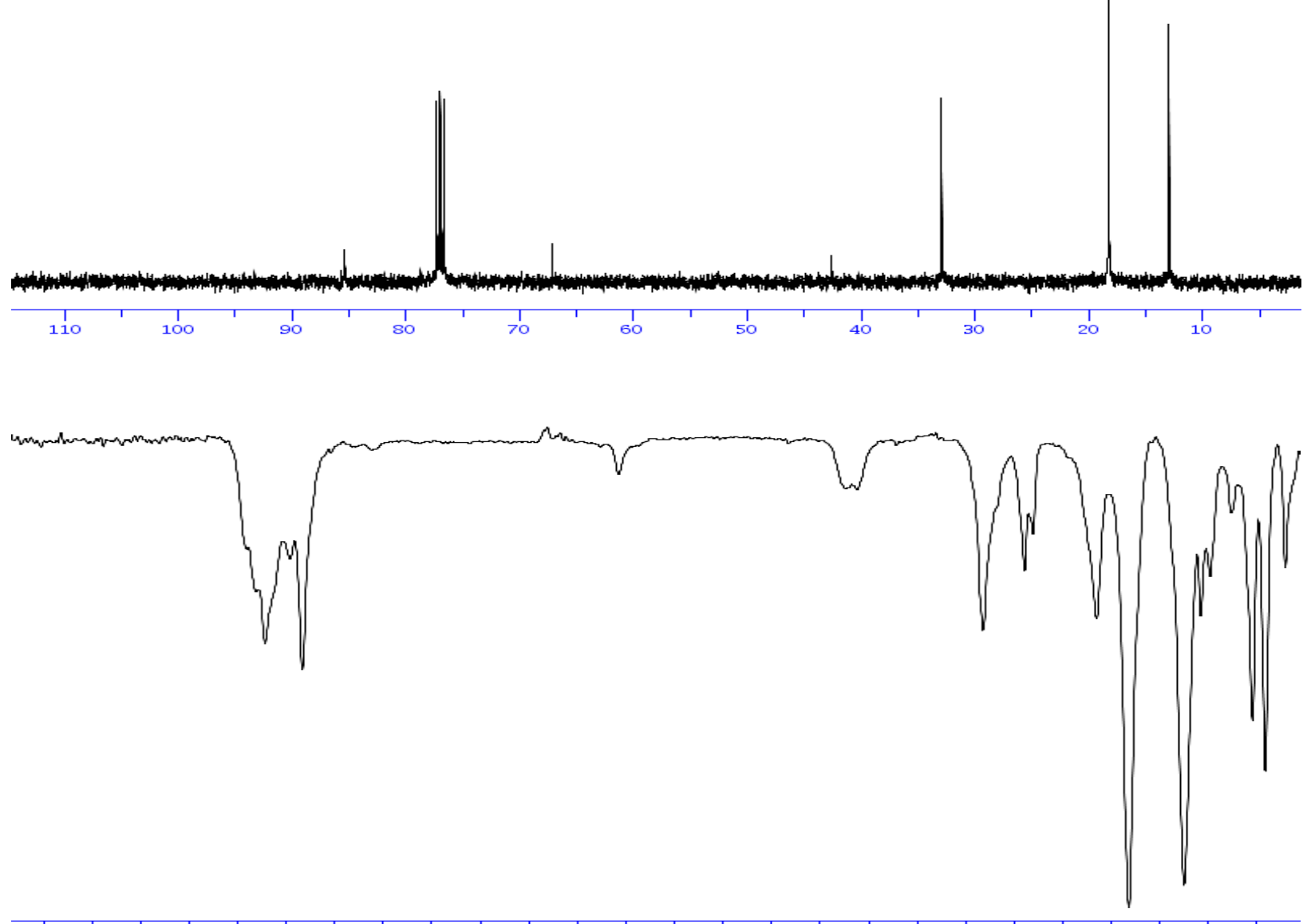
(((1-Bromonon-1-yn-3-yl)oxy)methyl)benzene (6j)

solvent: CDC13

$\mathrm{Br}$<smiles>CC#CC(CCCCCC)OCc1ccccc1</smiles>

6j

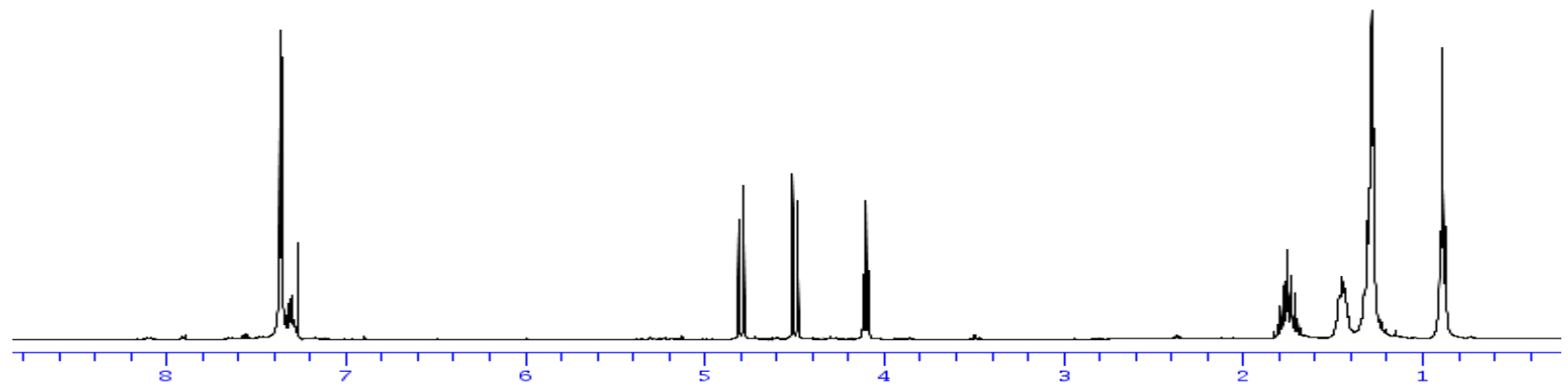

Solvent: $\mathrm{CDCI} 3$

Frequency. $100.61 \mathrm{MHz}$
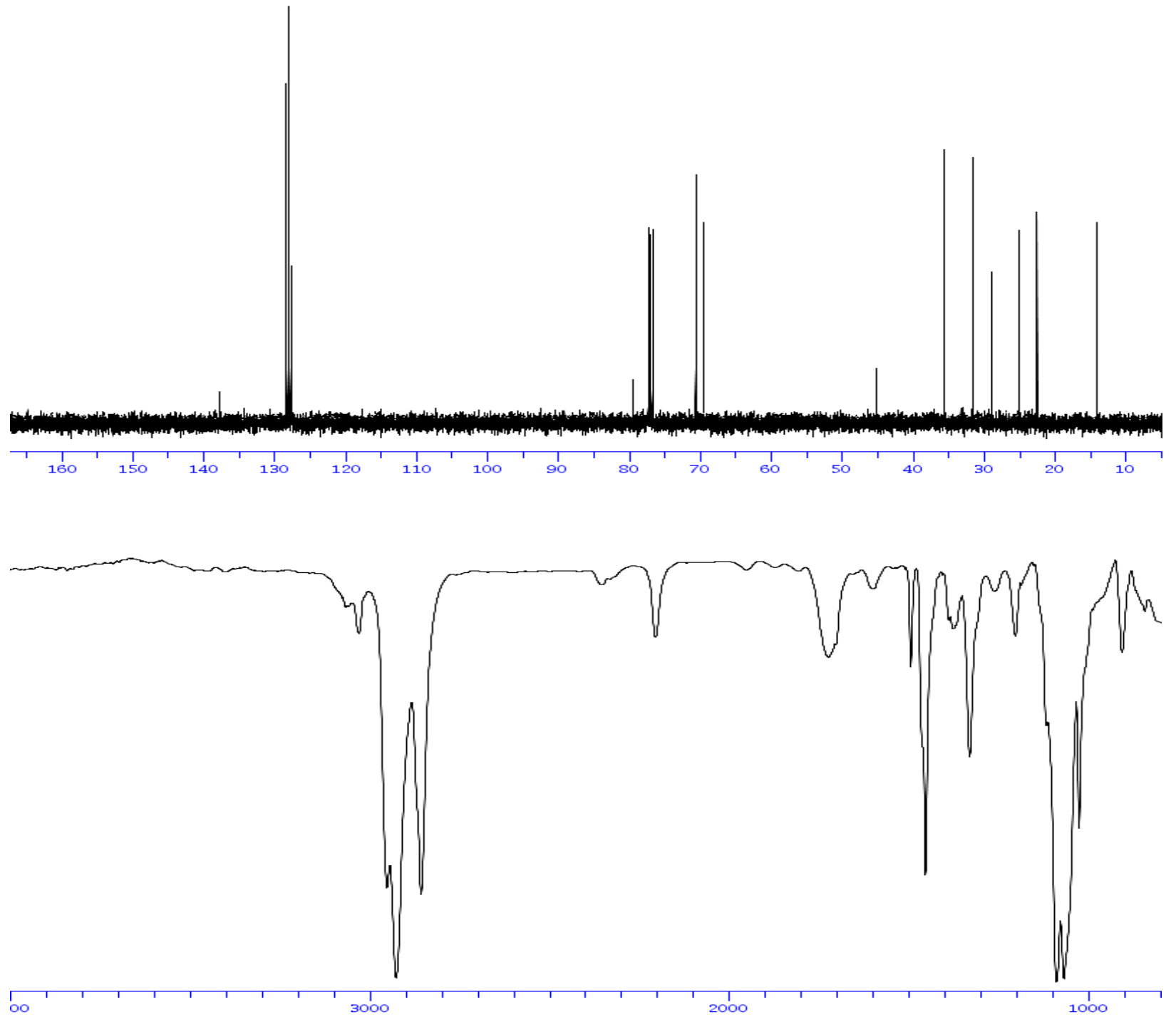
((1-Bromonon-1-yn-3-yl)oxy)triisopropylsilane (6k)

Solvent: $C D C I 3$

Frequency. $400.13 \mathrm{MHz}$
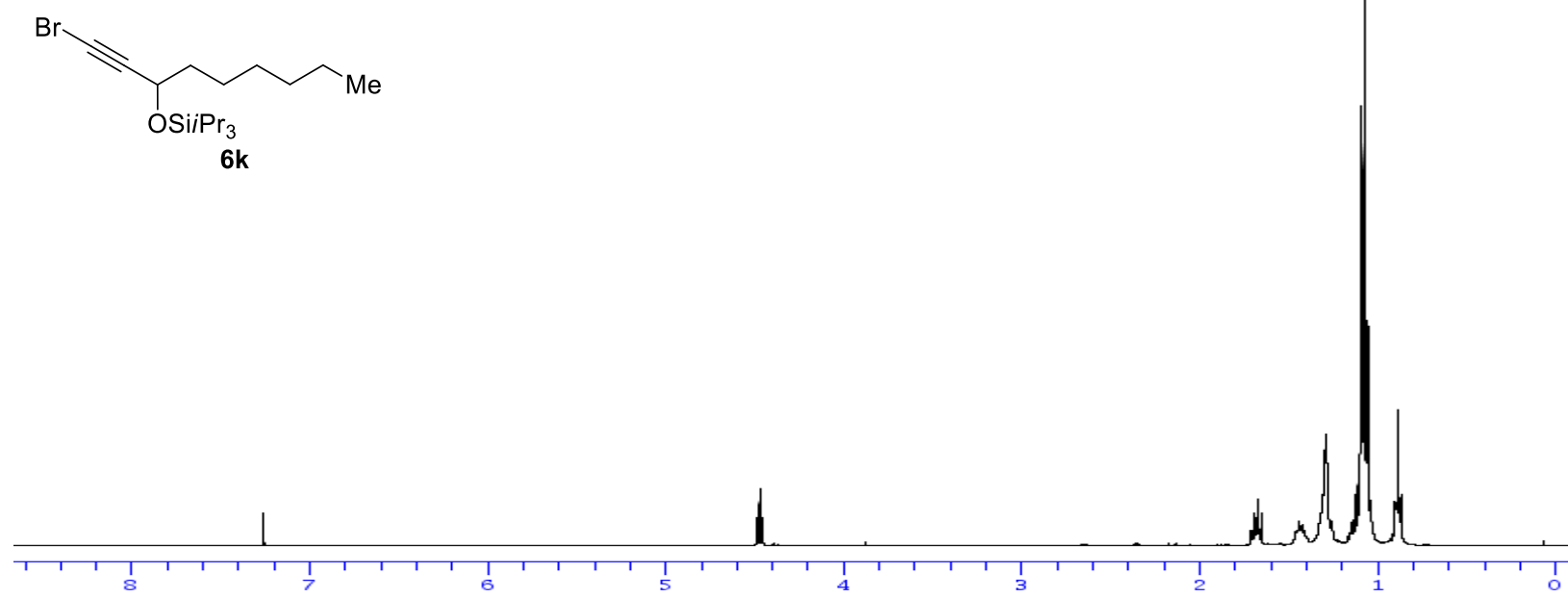

Solvent: $C D C I 3$

Frequency $100.61 \mathrm{MHz}$
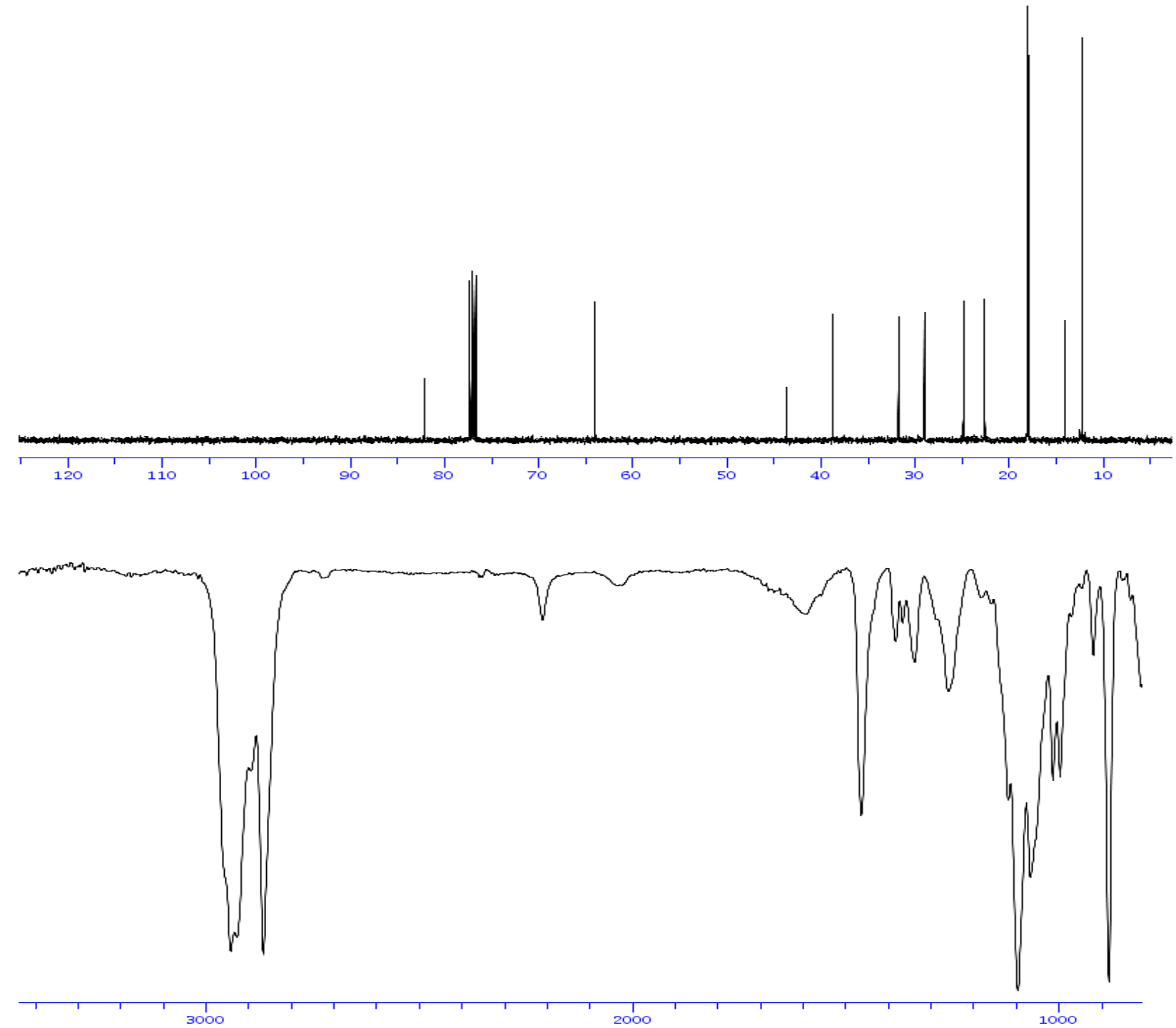


\section{1,9-Dibromonon-1-yne (6I)}

Solvent: $\mathrm{CDCl} 3$

Frequency. $400.11 \mathrm{MHz}$

$\mathrm{Br}$<smiles>CC#CCCCCCCBr</smiles>

61

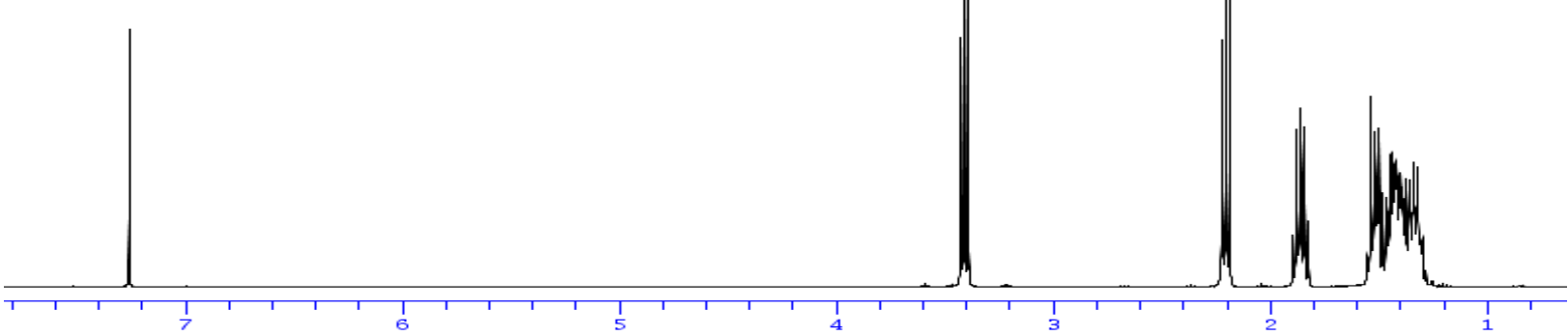

Solvent: $\mathrm{CDCI}$

$00.61 \mathrm{MHz}$
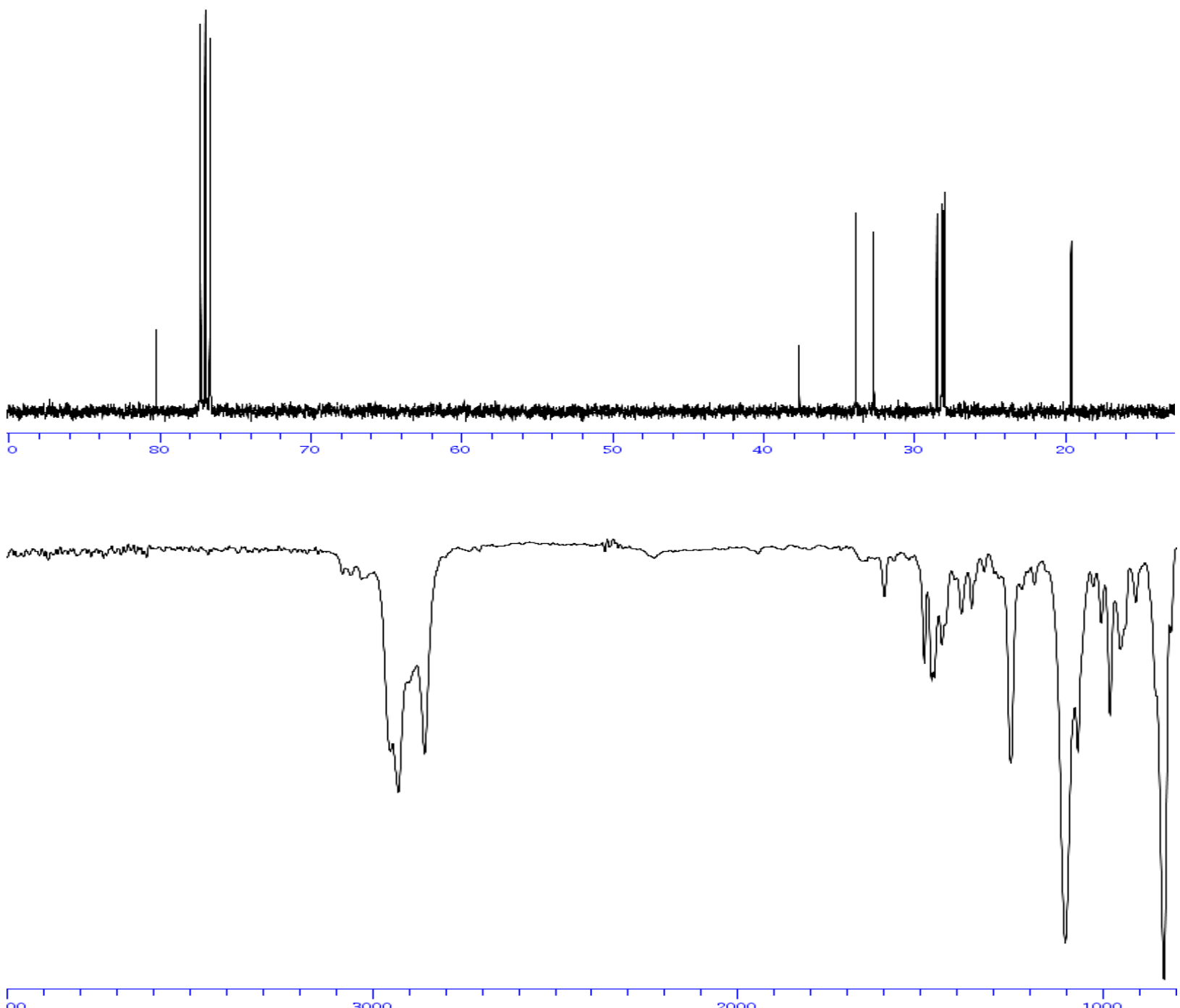
2-(Non-2-yn-1-yl)tetrahydrofuran (7aa)

Solvent: $C D C I 3$

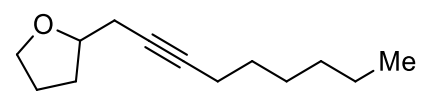

7 aa

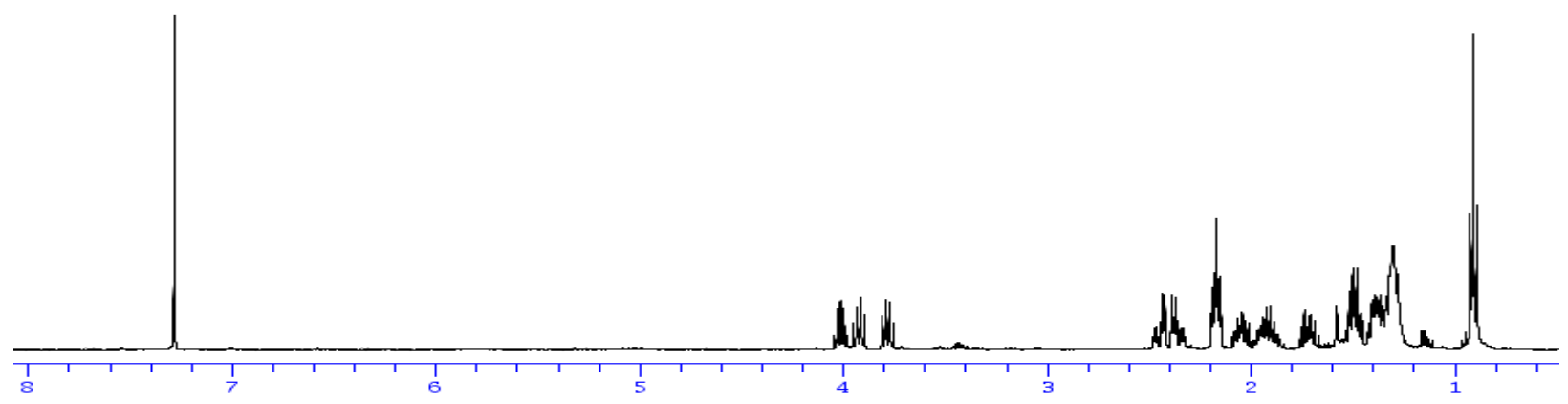

Solvent: $\mathrm{CDCl}$

. $100 \mathrm{MHz}$
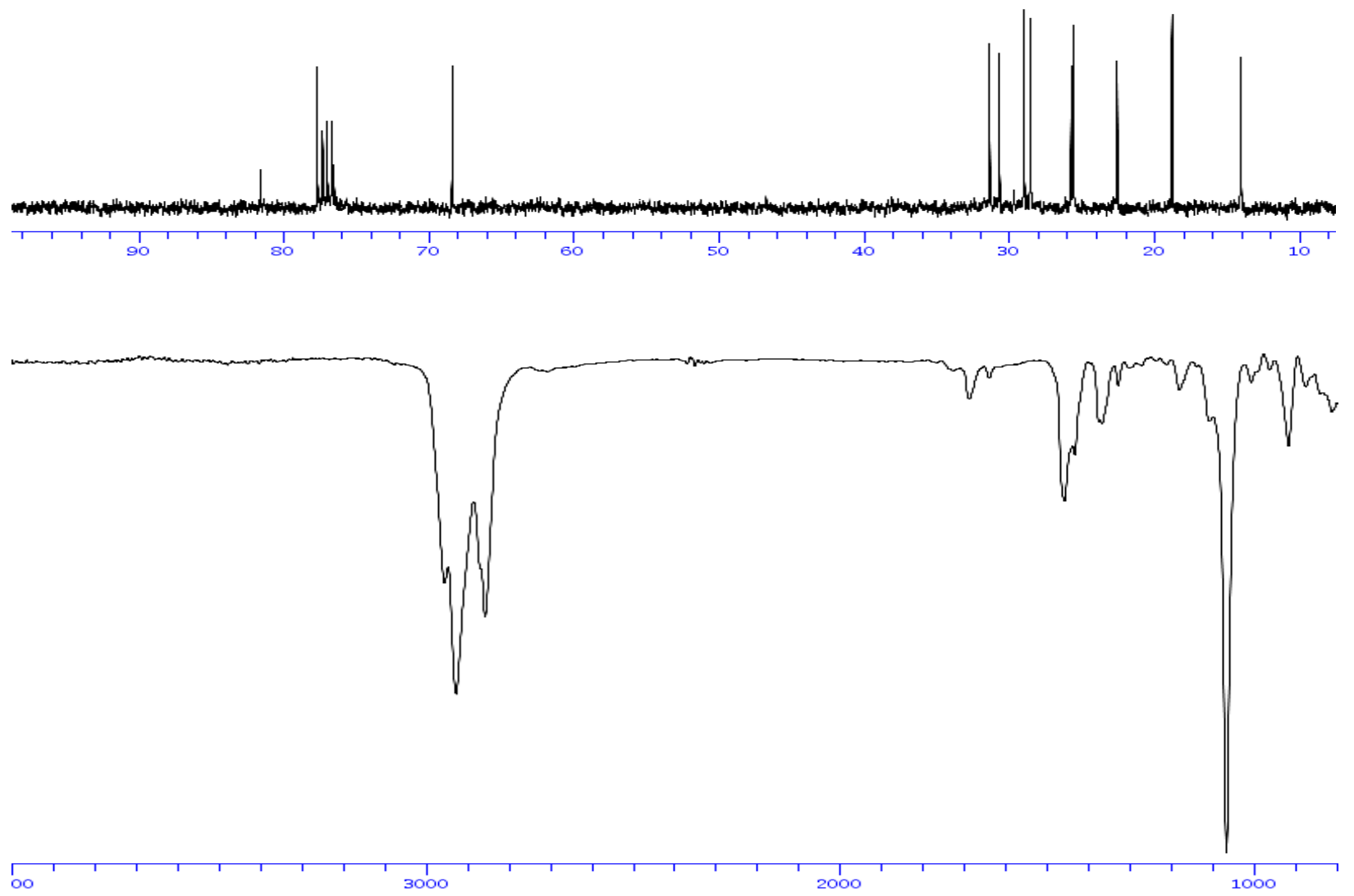
tert-Butyldiphenyl((6-(tetrahydrofuran-2-yl)hex-4-yn-1-yl)oxy)silane (7ad)

Solvent: $\mathrm{CDCl} 3$

Frequency $400.11 \mathrm{MHz}$
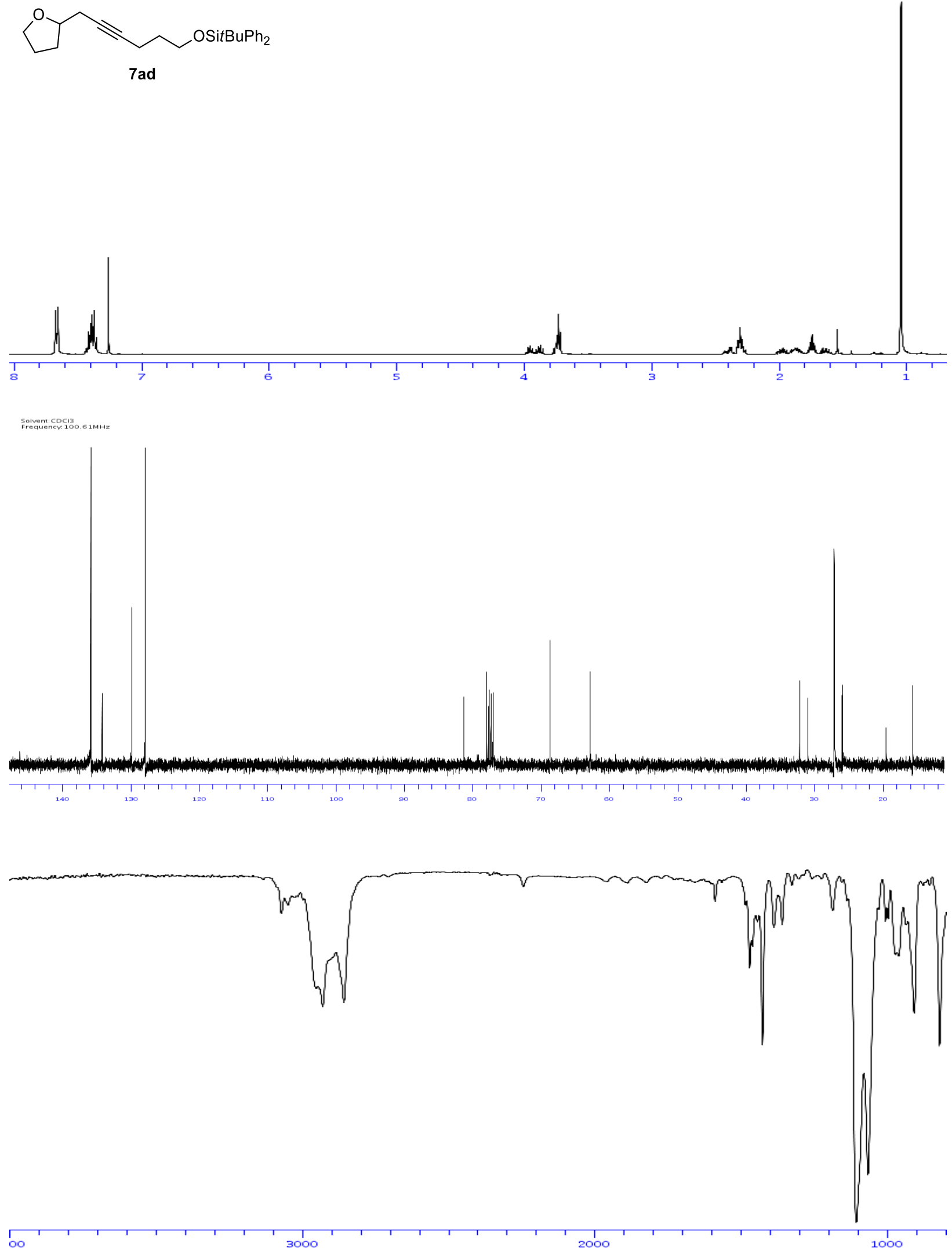
2-(6-Phenylhex-2-yn-1-yl)tetrahydrofuran (7ae)

Solvent: $\mathrm{CDCl} 3$

Frequency $400.13 \mathrm{MHz}$

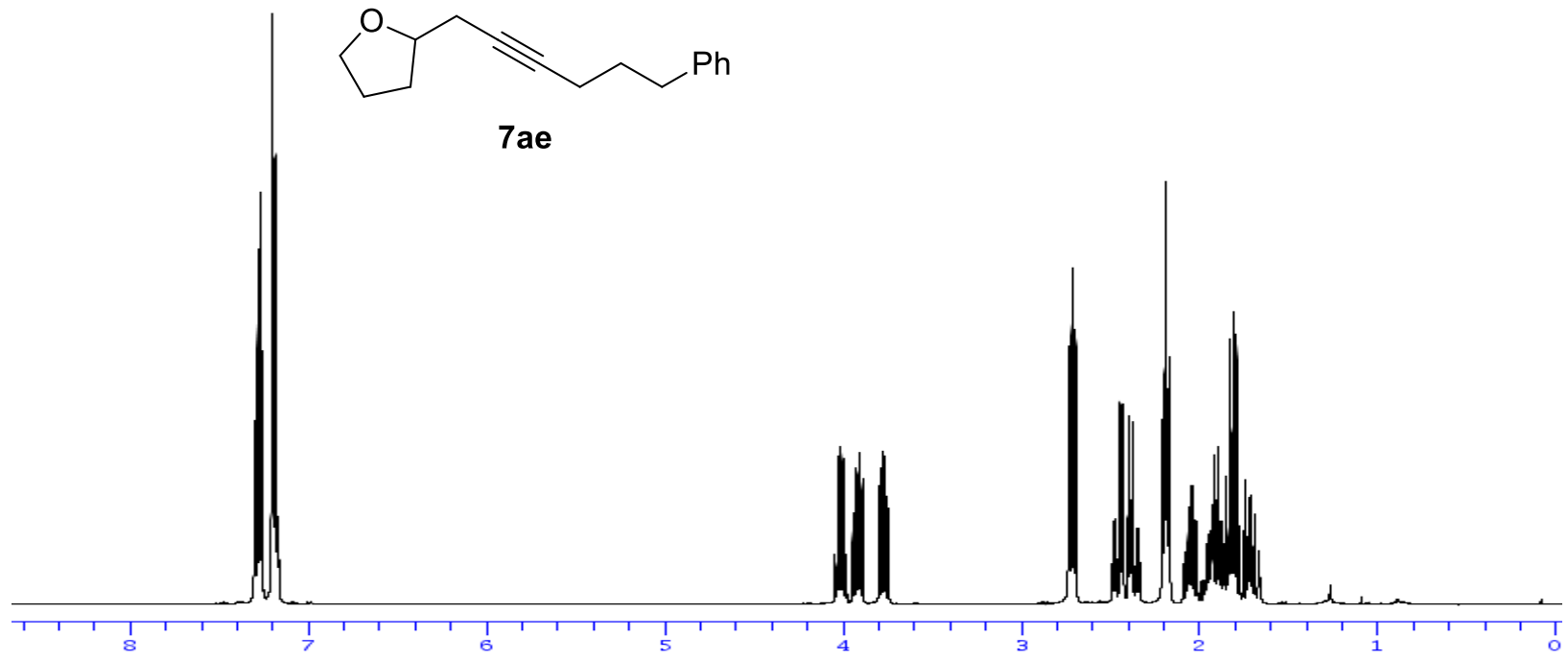

Solvent: $C D C 13$
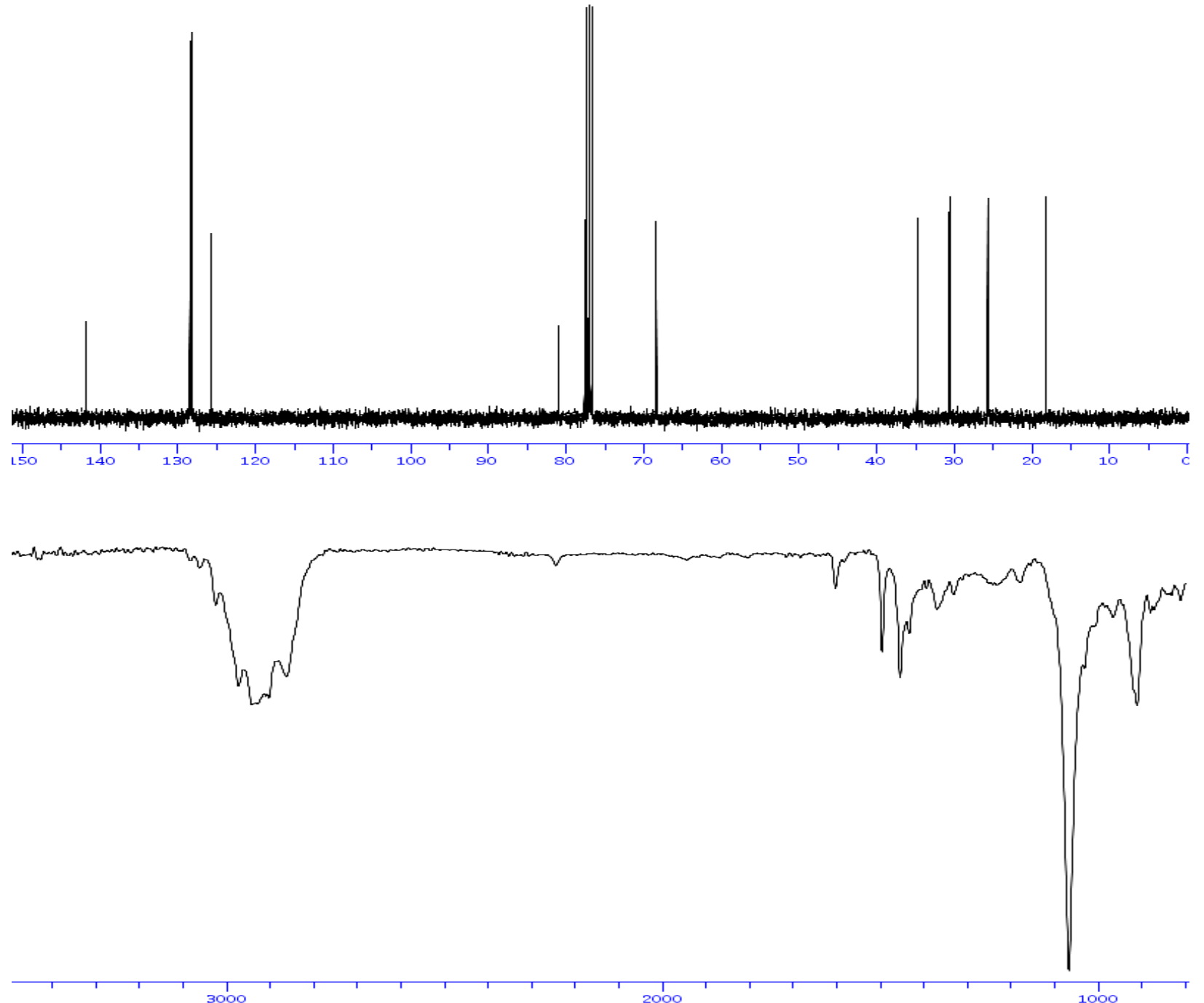


\section{2-(6-Chlorohex-2-yn-1-yl)tetrahydrofuran (7af)}

Solvent: $C D C I 3$
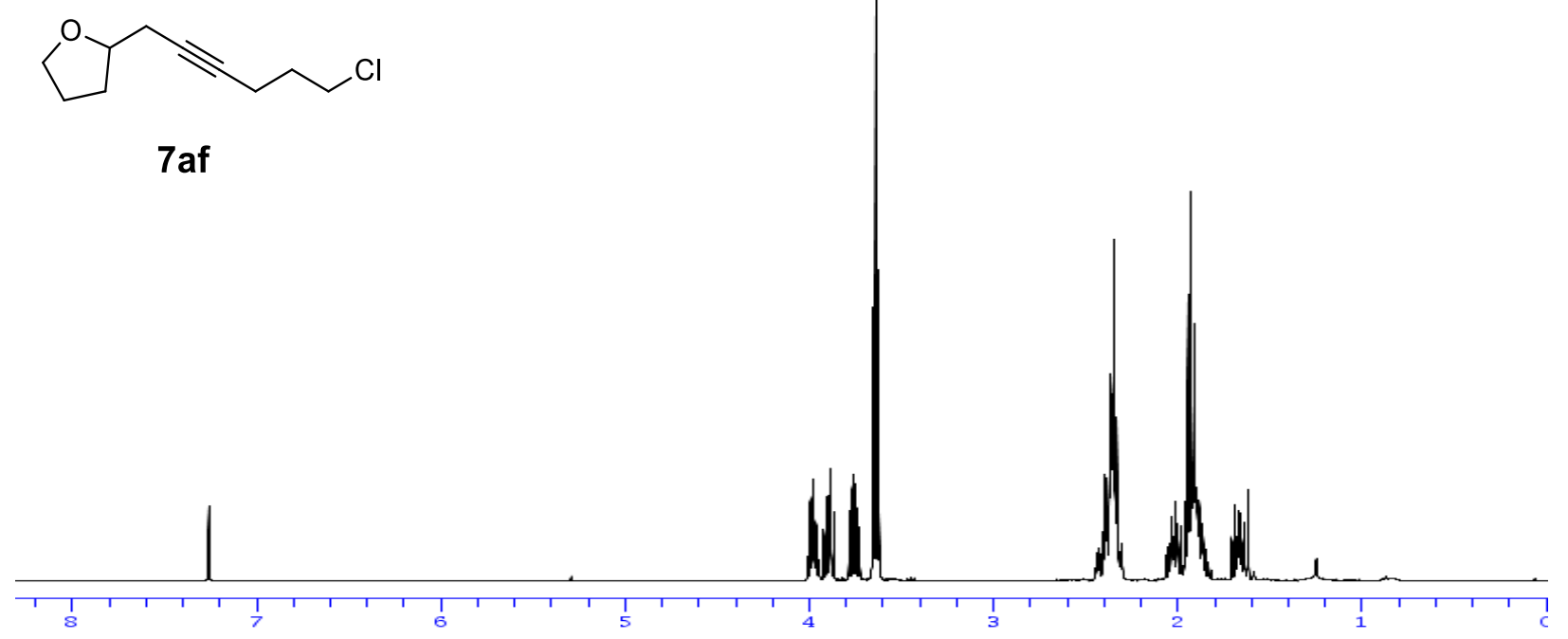

Solvent: $C D C I 3$
Frequency. $100.61 \mathrm{MHz}$
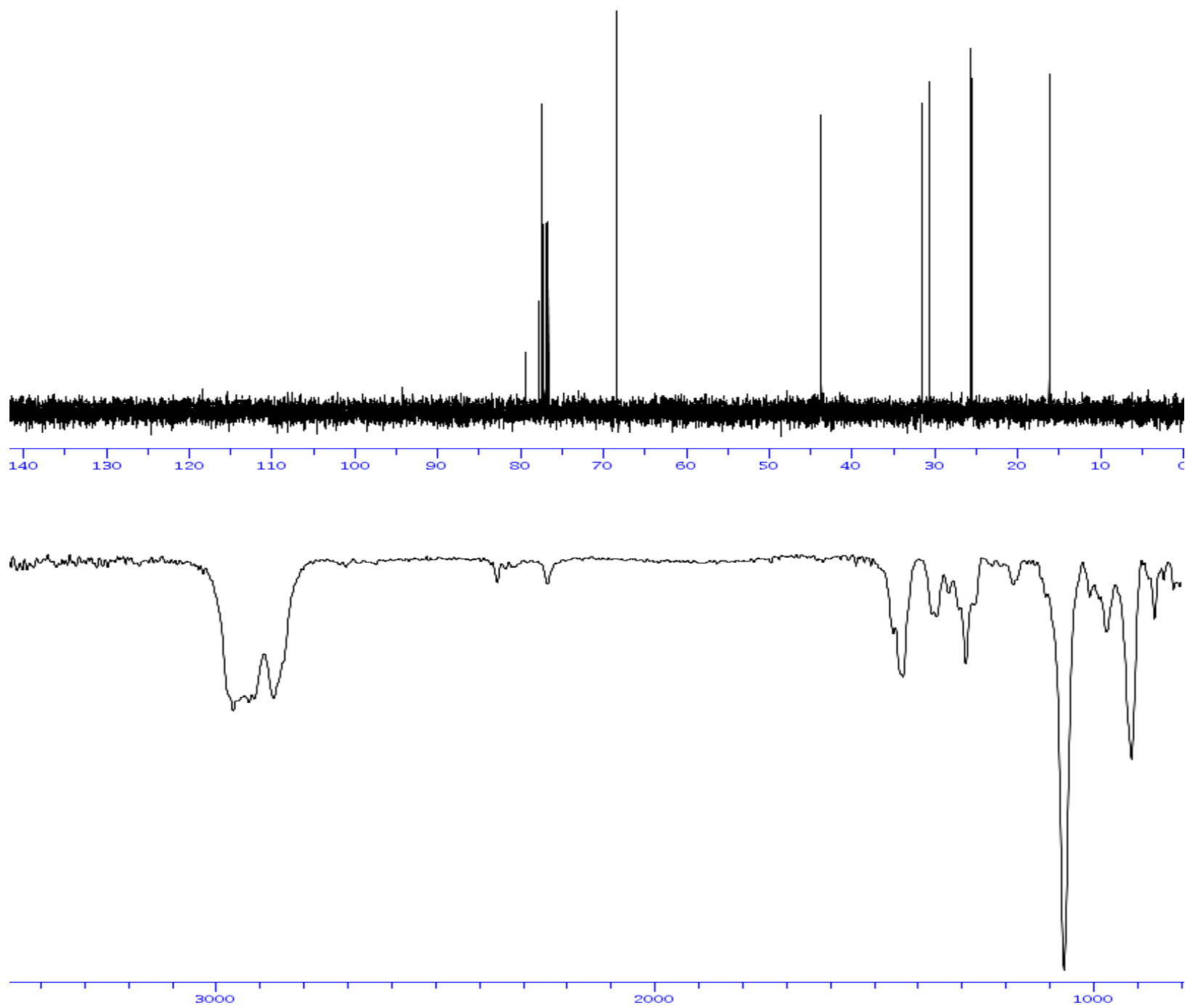
Triisopropyl(8-(tetrahydrofuran-2-yl)octa-1,6-diyn-1-yl)silane (7ag)

Solvent: $\mathrm{CDCI}$
Frequency. $400.03 \mathrm{MHz}$<smiles>C#CCC1CCCO1</smiles>

7 ag

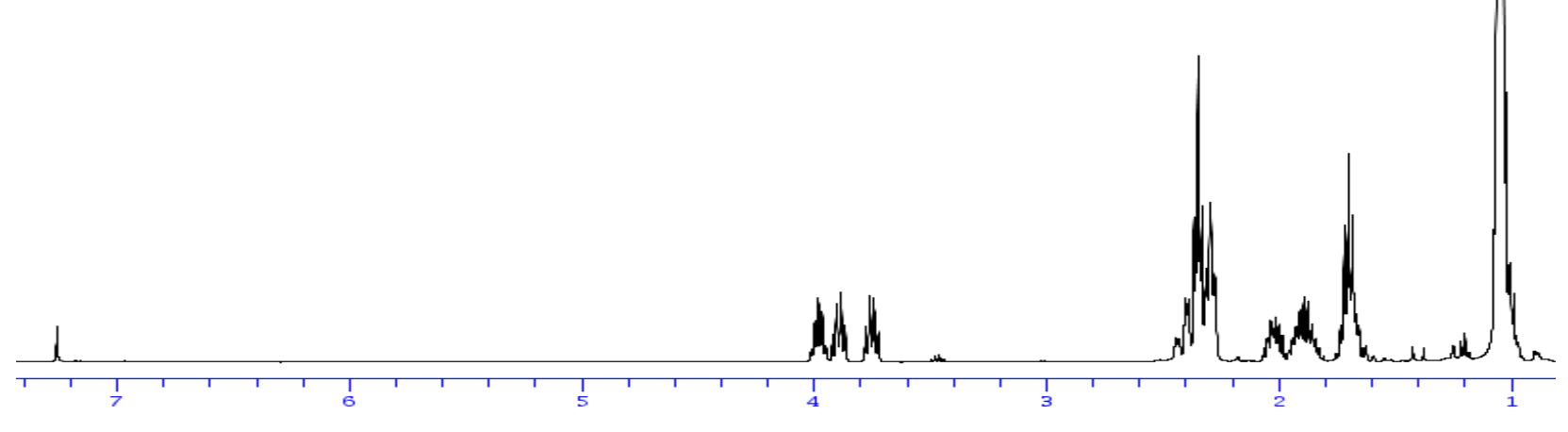

Solvent: $C D C I 3$

. $1 \mathrm{MHz}$
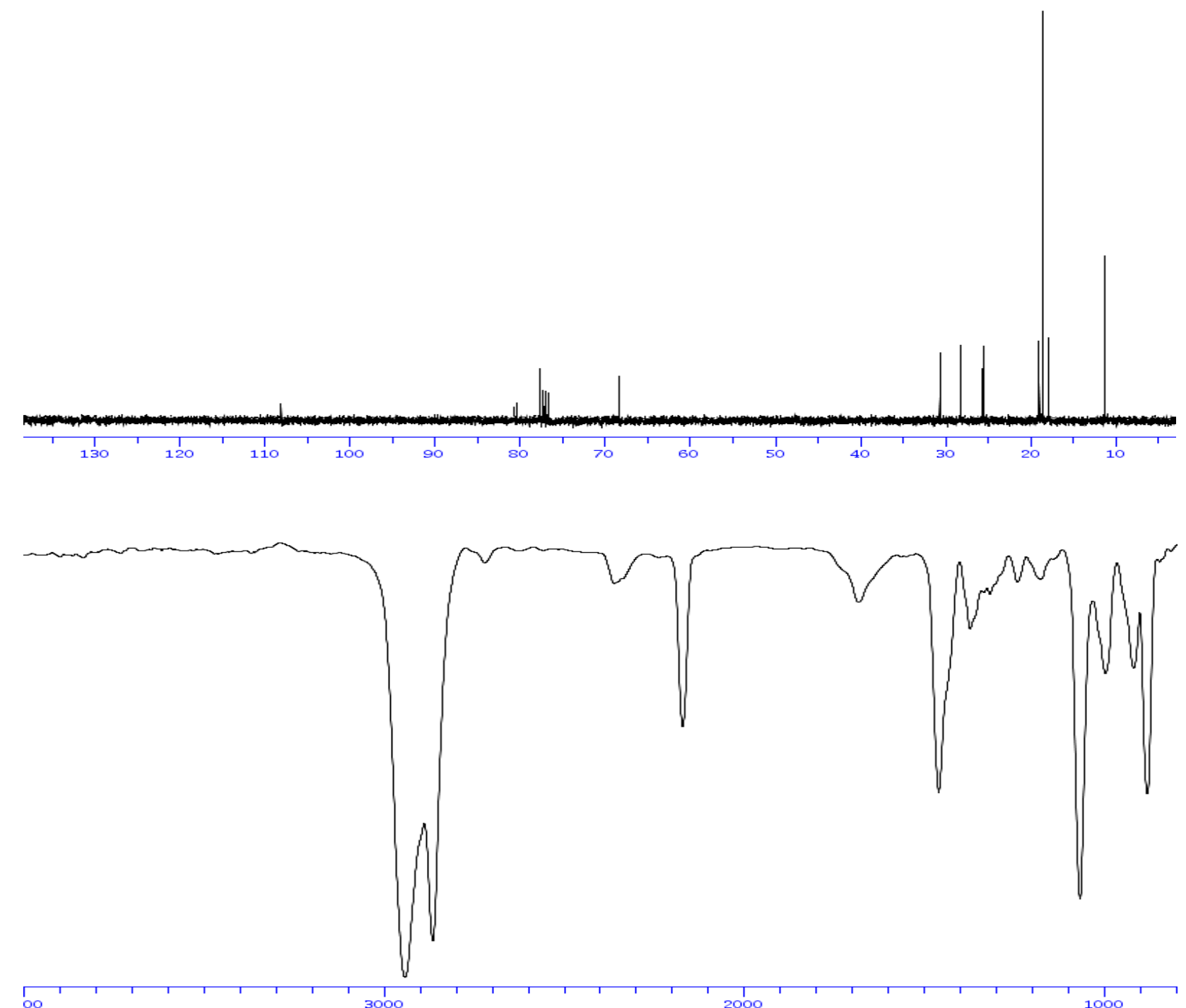


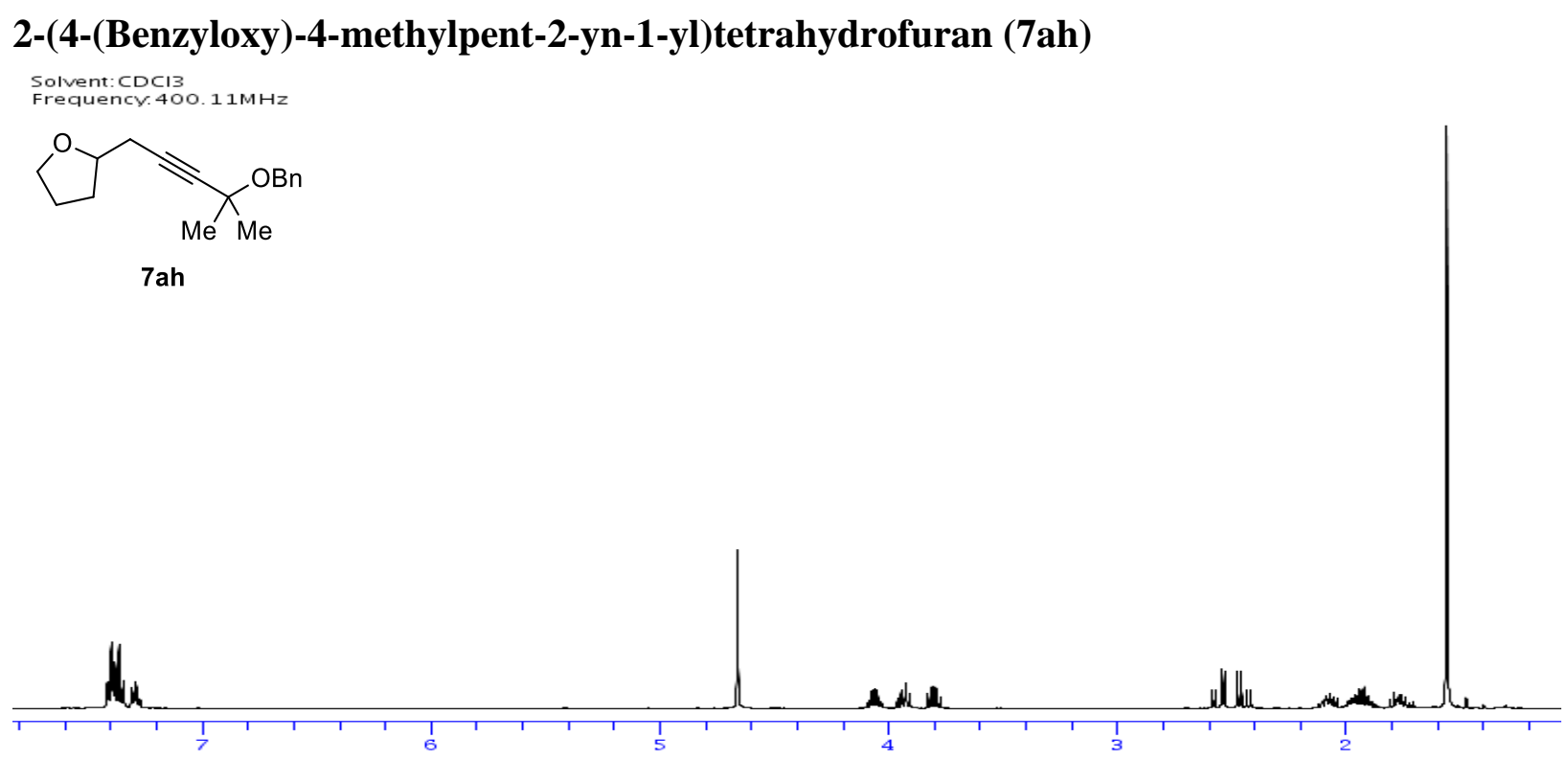

Solvent: $C D C 13$

Frequency. 100.61MHz
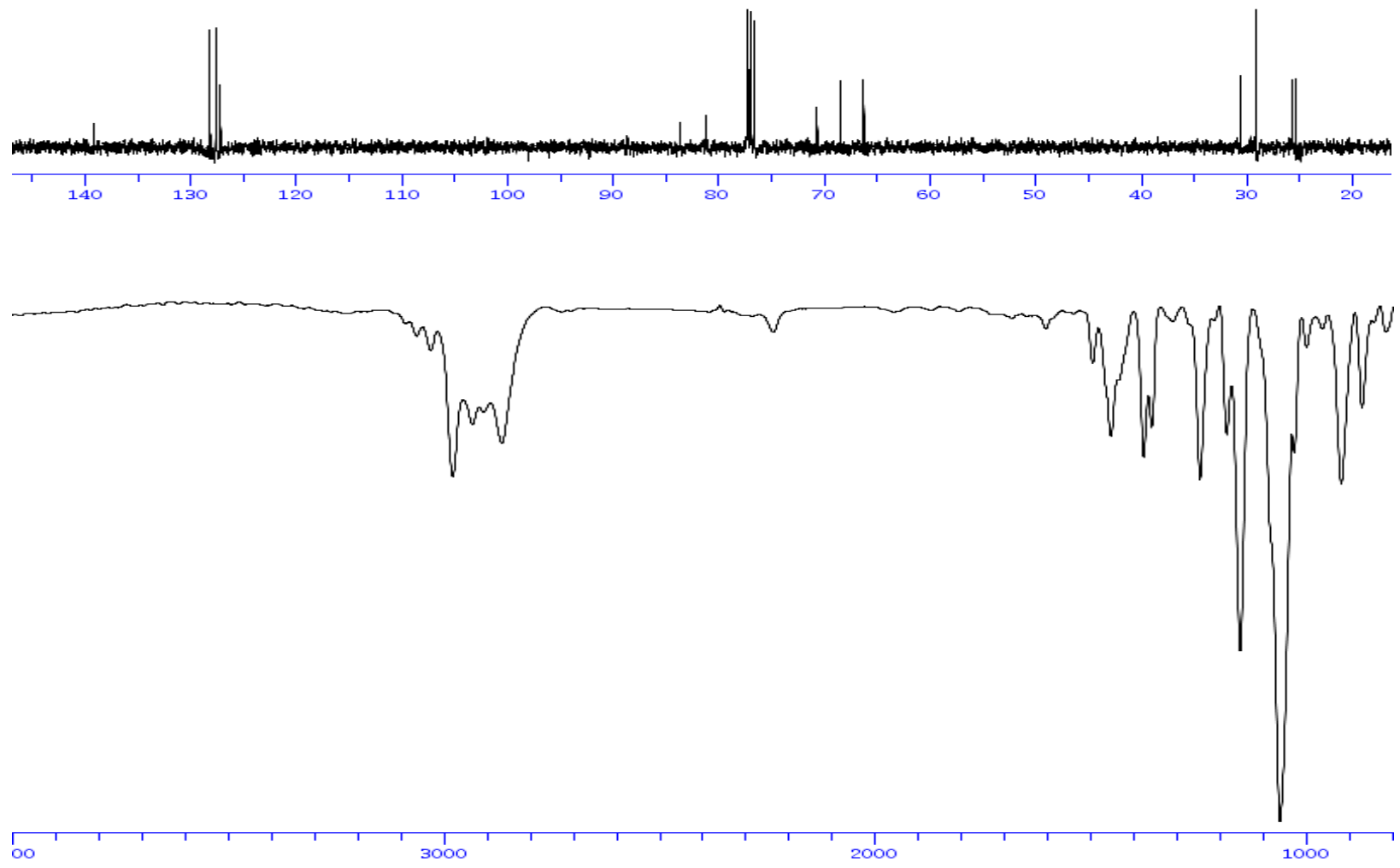
Triisopropyl((2-methyl-5-(tetrahydrofuran-2-yl)pent-3-yn-2-yl)oxy)silane (7ai)
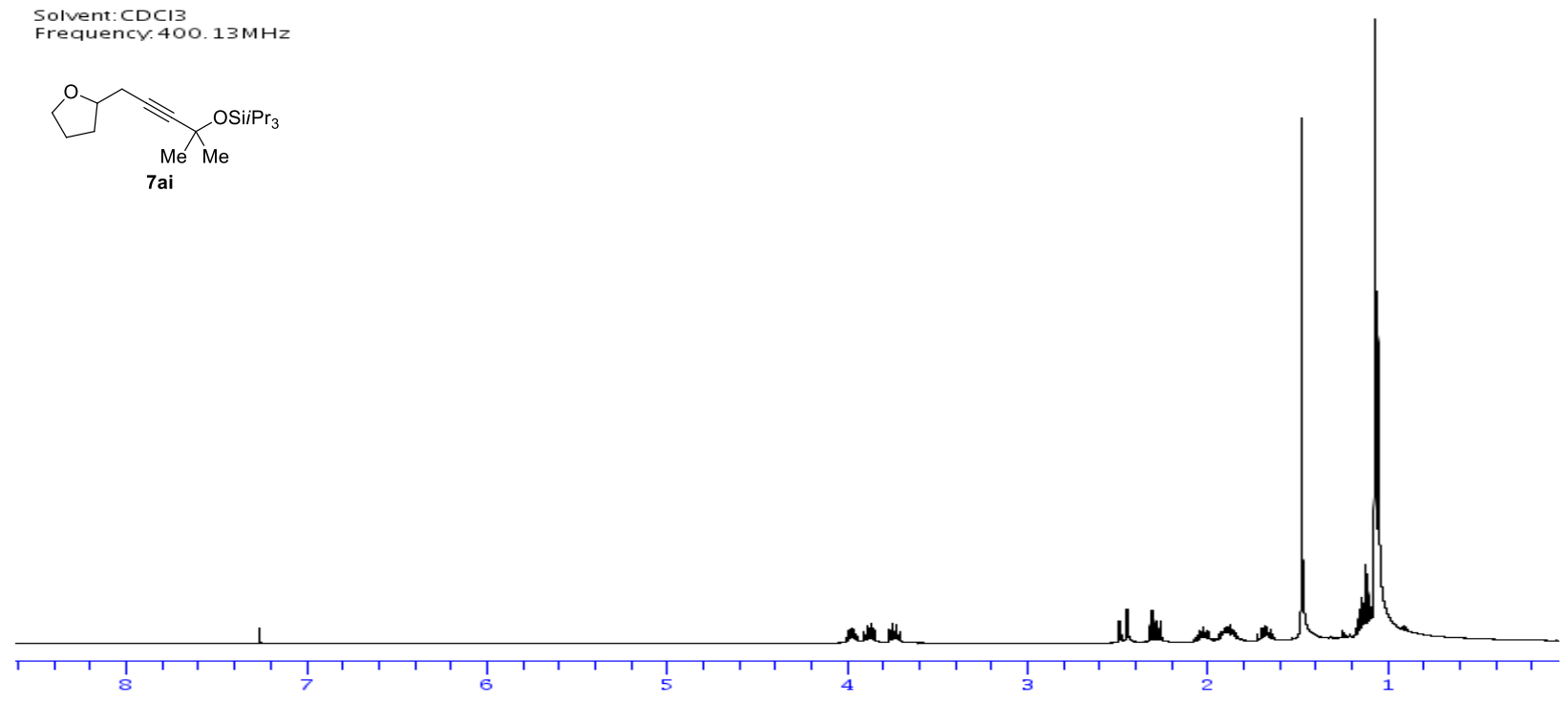

solvent: $C D C I 3$

Frequency. $100.61 \mathrm{MHz}$
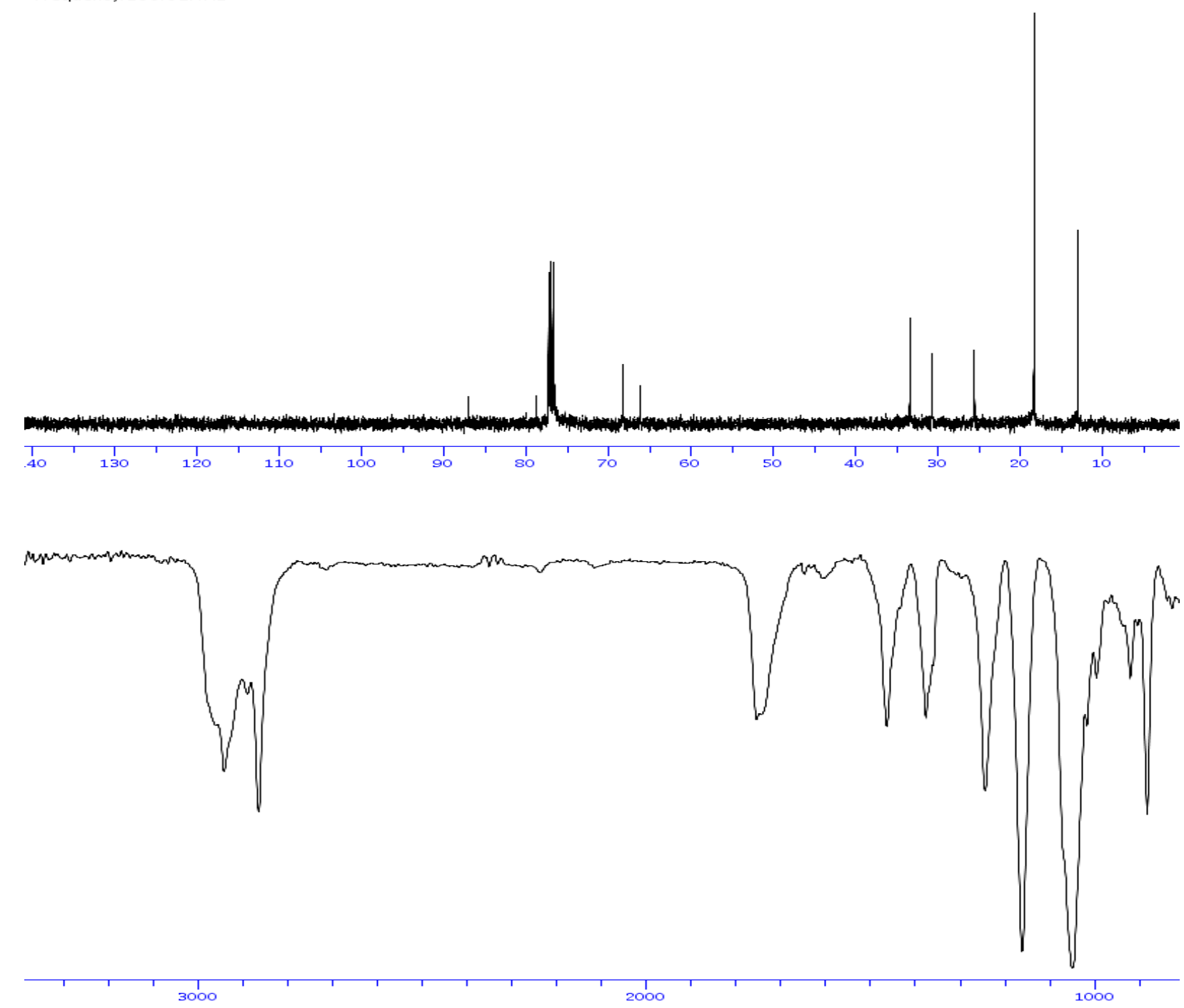


\section{2-(4-(Benzyloxy)dec-2-yn-1-yl)tetrahydrofuran (7aj)}

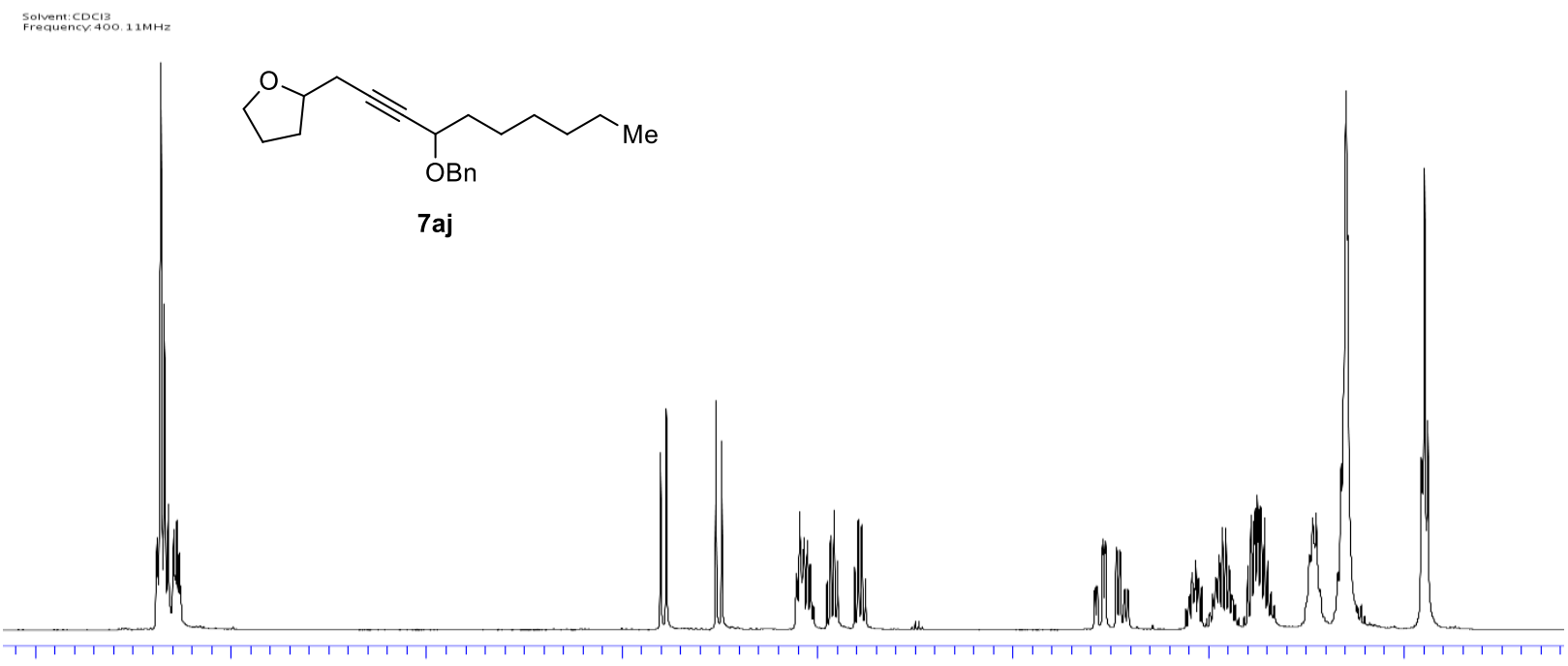

Solvent: $C D C 13$
Frequency. $100.61 \mathrm{MHz}$
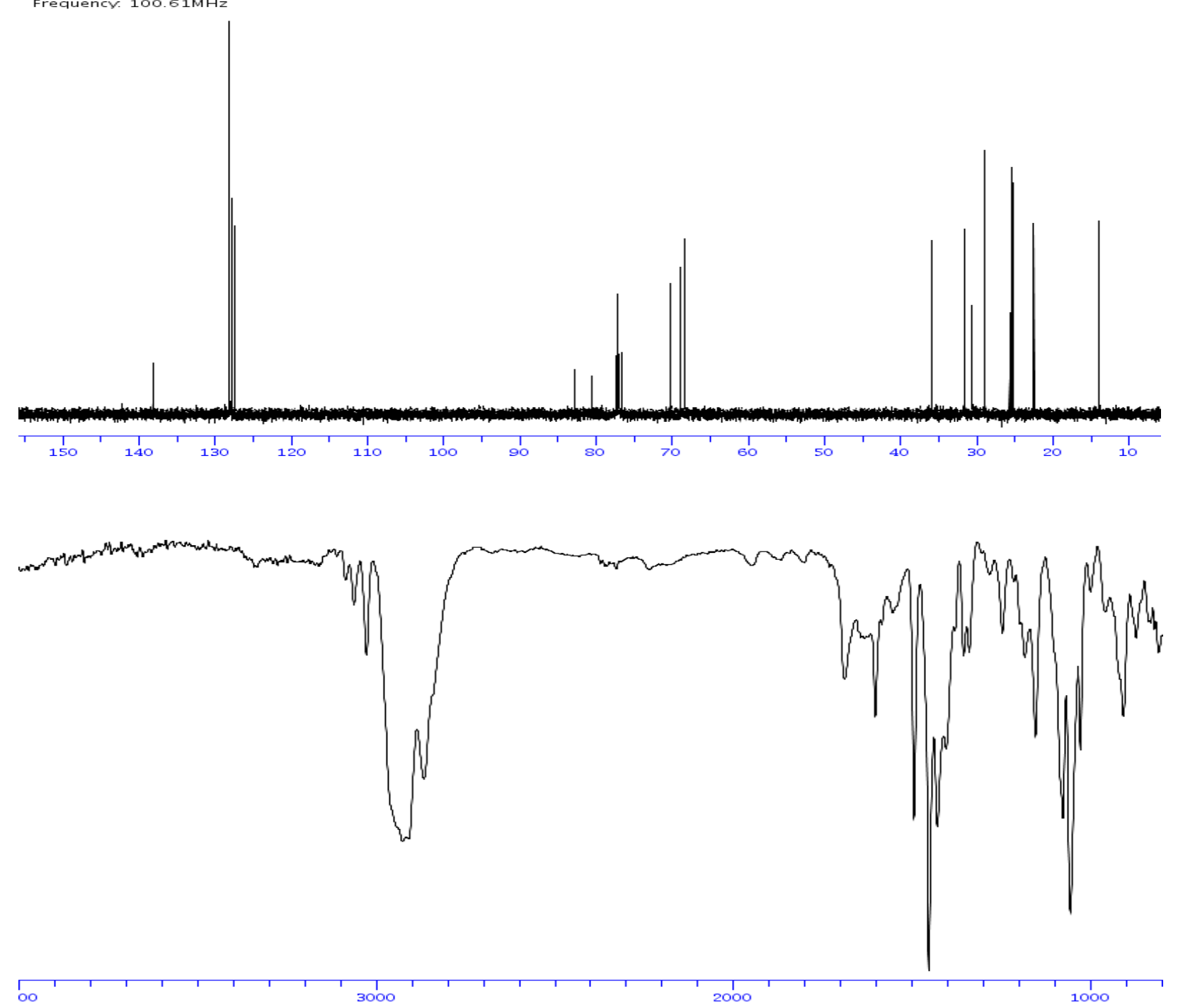
Triisopropyl((1-(tetrahydrofuran-2-yl)dec-2-yn-4-yl)oxy)silane (7ak)

Solvent: $C D C 13$

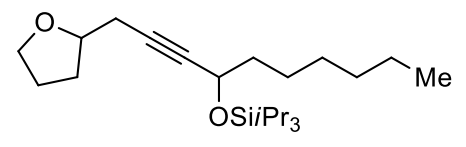

7ak

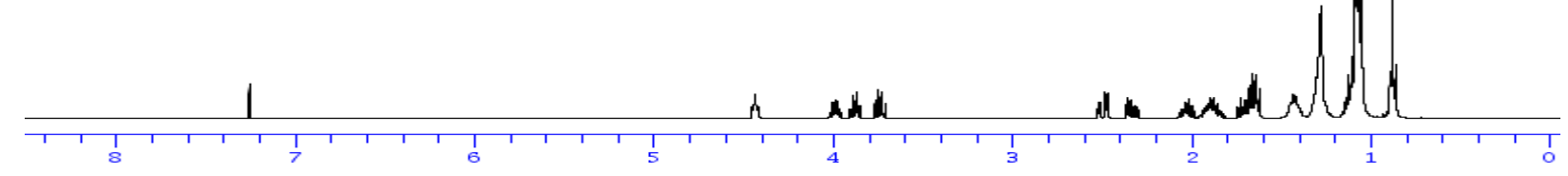

Solvent: $\mathrm{CDCI} 3$

Frequency. 100.61 $\mathrm{MHz}$
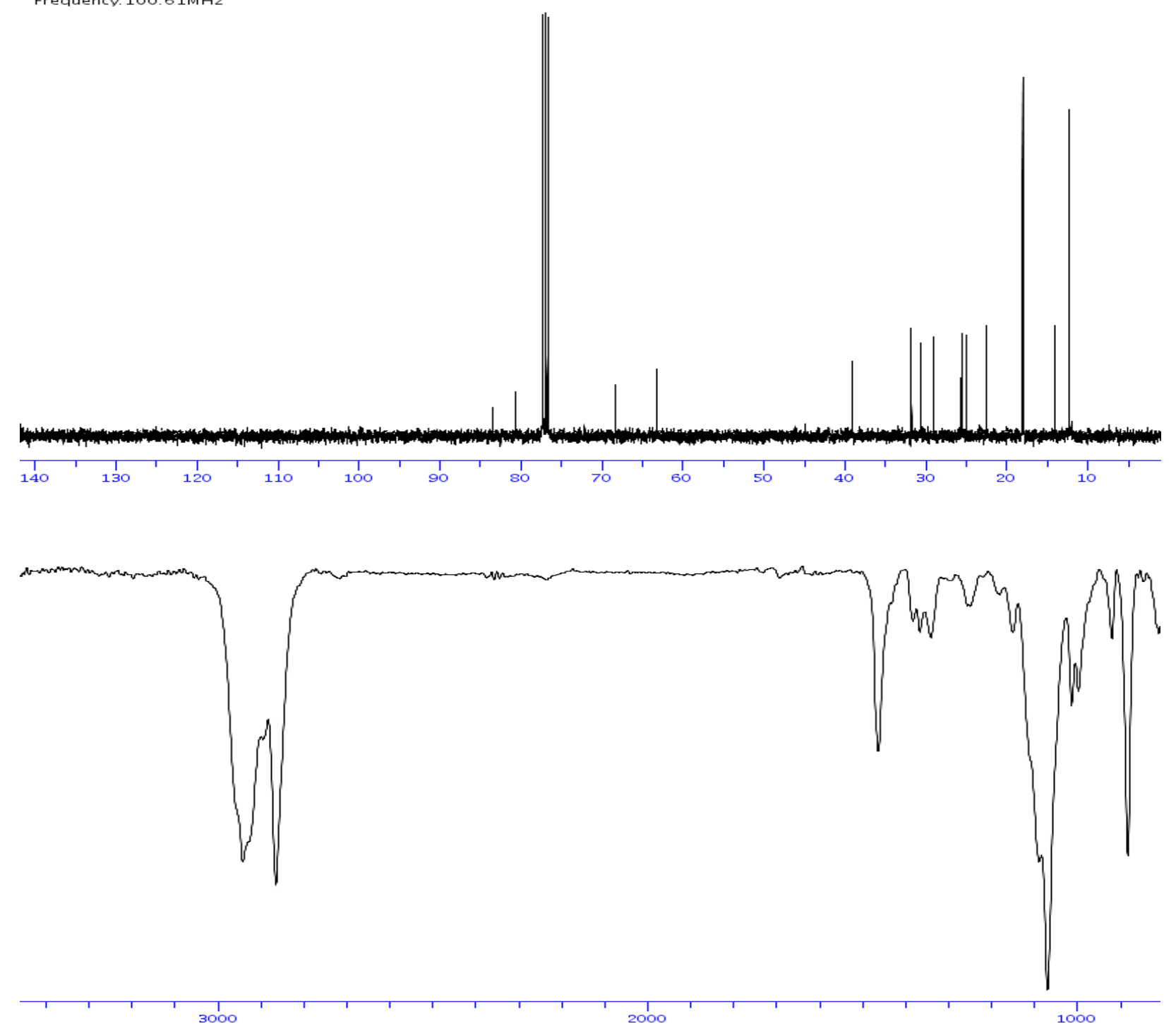


\section{2-(4-(Benzyloxy)-4-methylpent-2-yn-1-yl)-5-phenyltetrahydrofuran (7bh)}

Solvent: $C D C I 3$

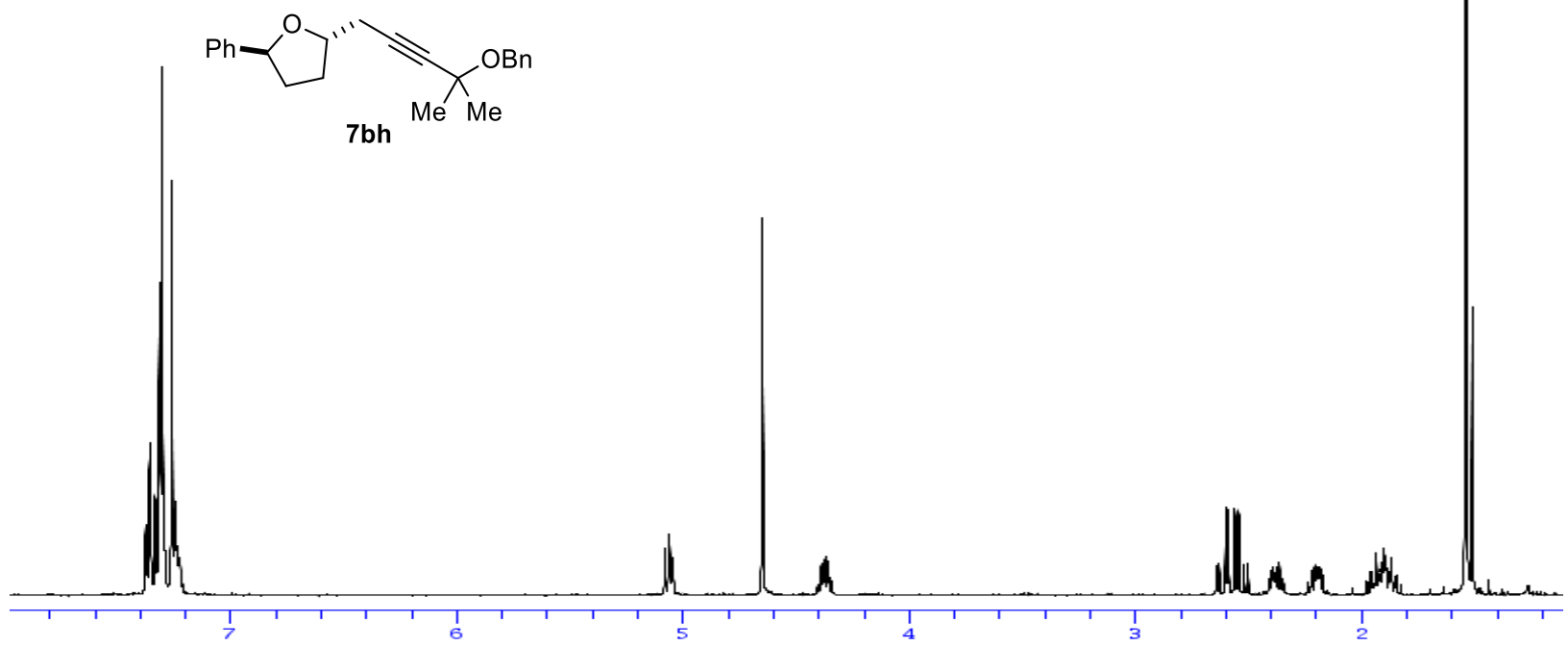

Solvent: $\mathrm{CDCI} 3$

$.61 \mathrm{MHz}$
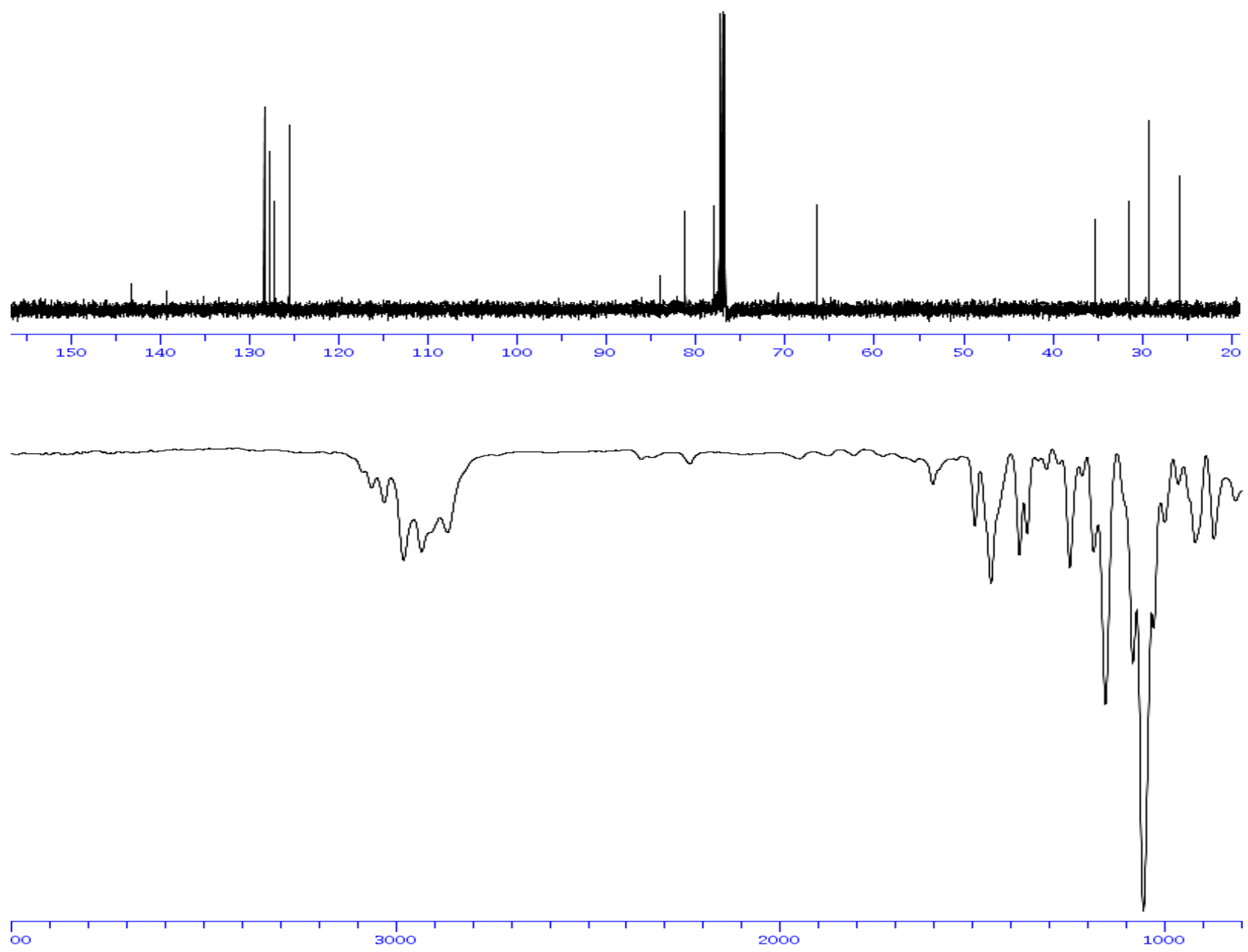


\section{2,5-Di(non-2-yn-1-yl)tetrahydrofuran (7ca)}

Solvent: $C D C I 3$
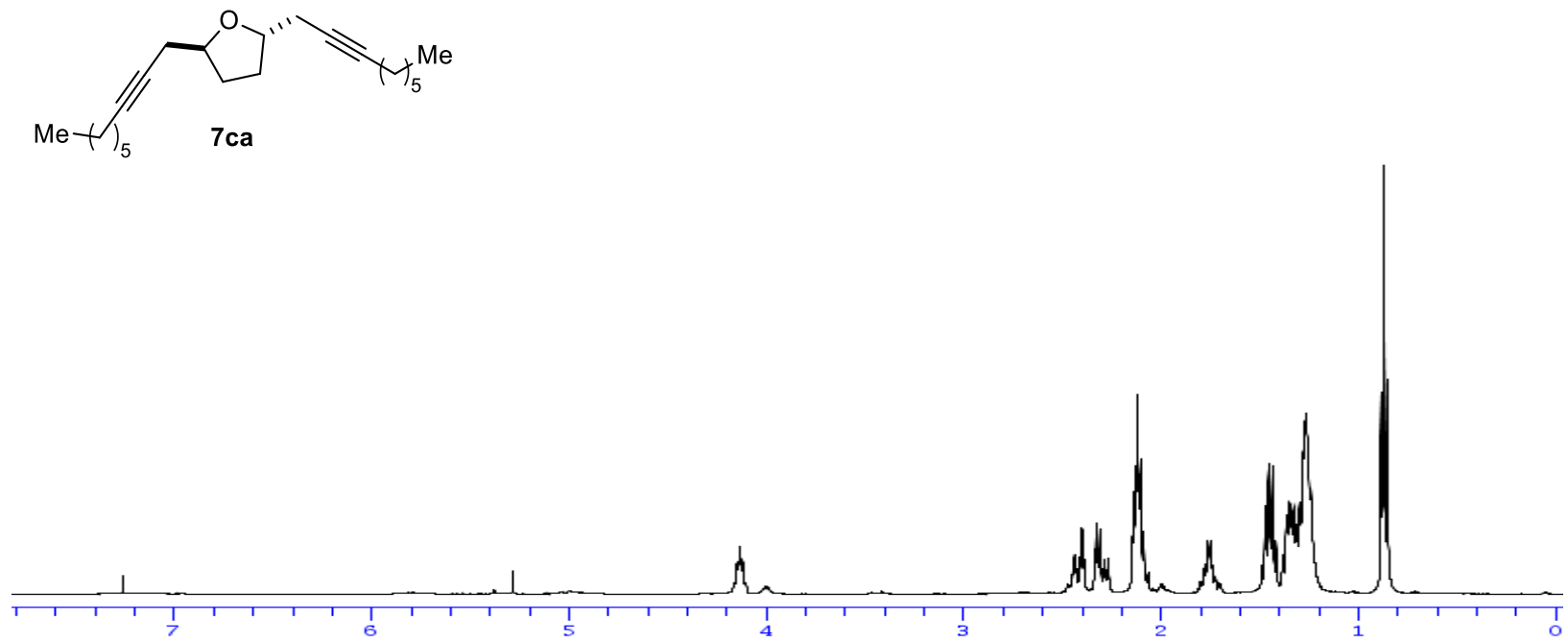

Solvent: $\mathrm{CDCI3}$

. $61 \mathrm{MHz}$
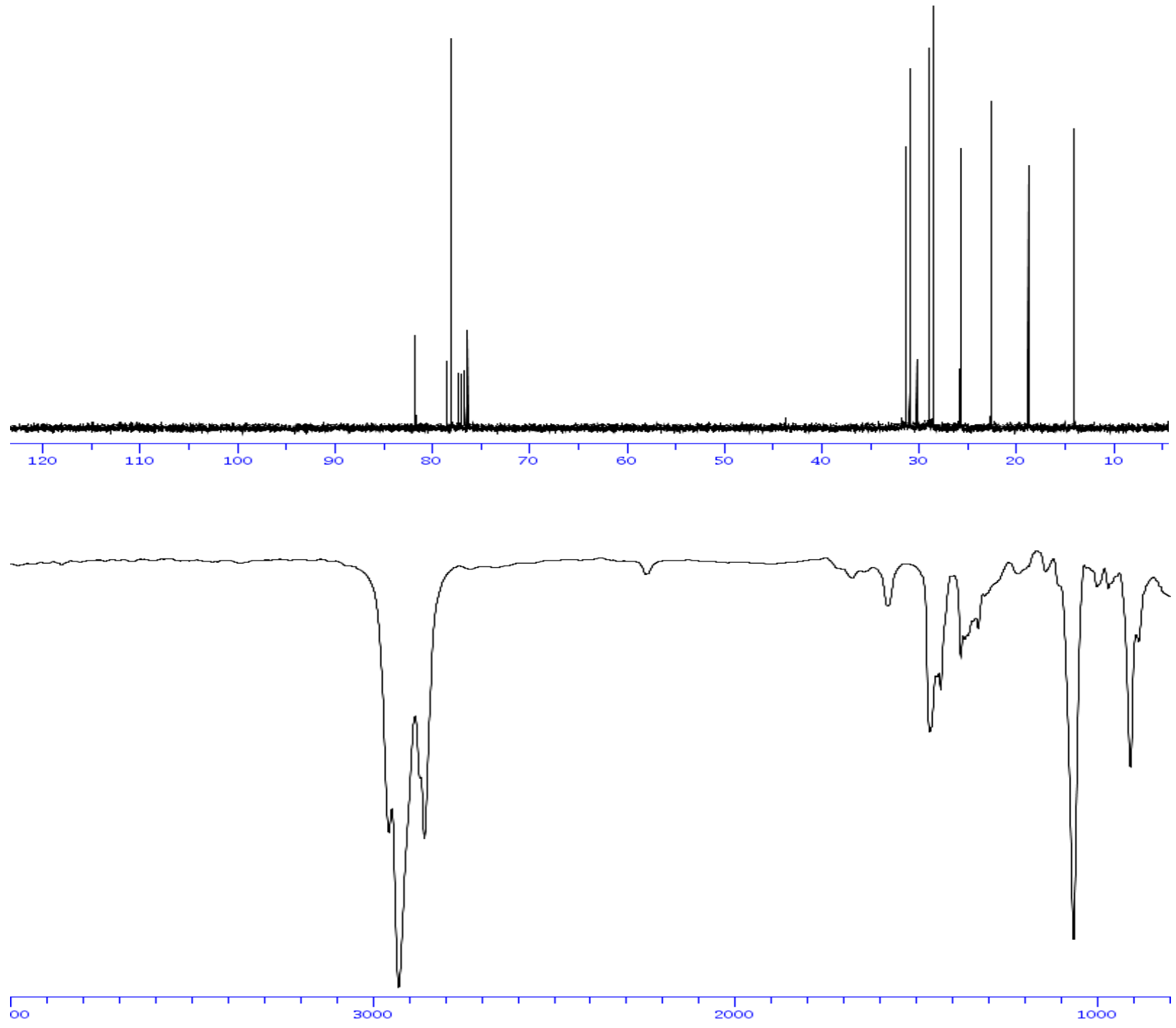
tert-Butyl undec-1-en-5-ylcarbamate (9c)

Solvent: $C D C I 3$
Frequency. 400.13
MHz
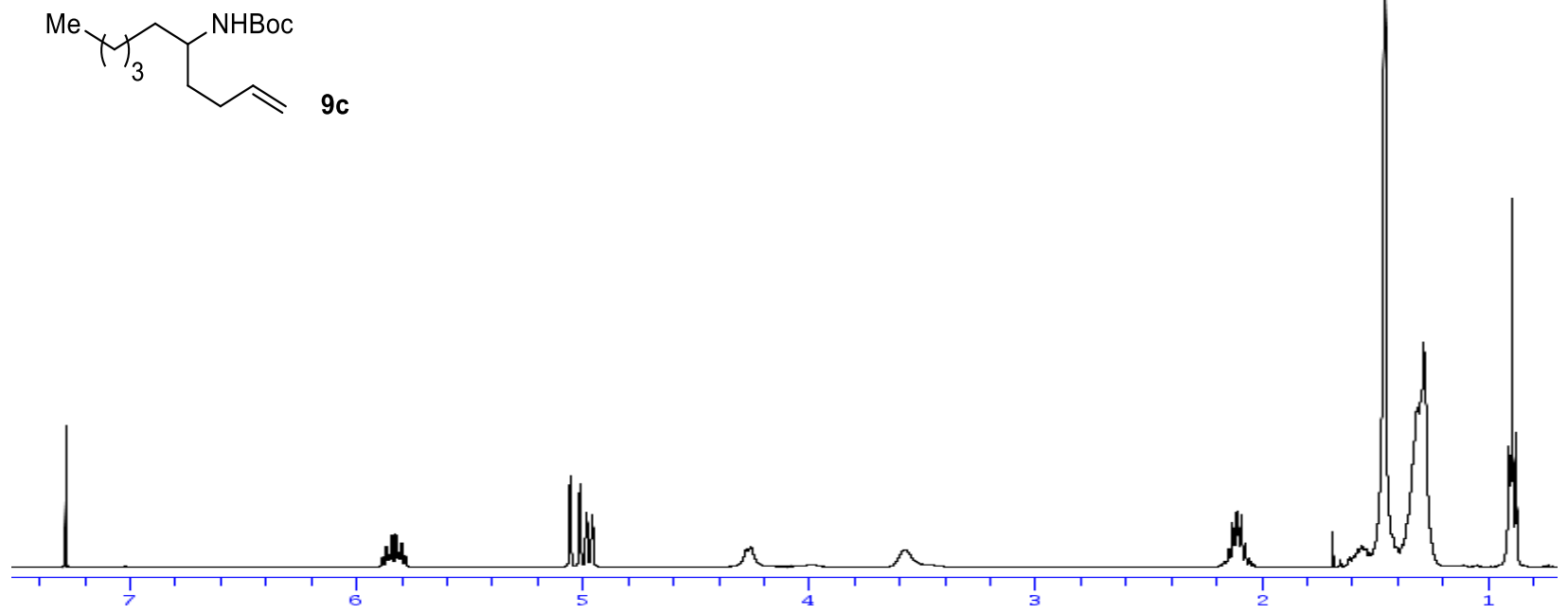

Solvent: $C D C 13$

Frequency. 100.61
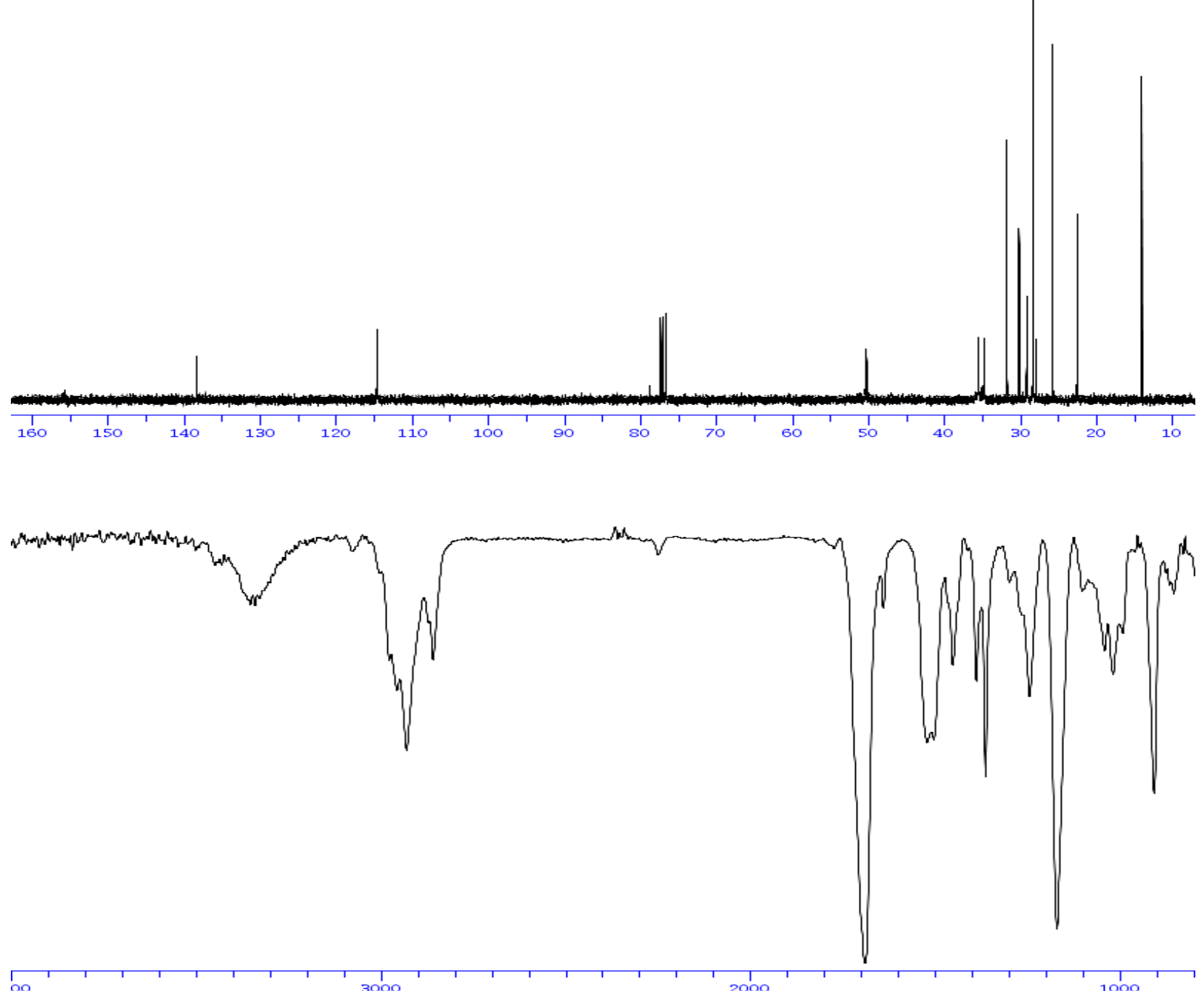
tert-Butyl (2-allylcyclopentyl)carbamate (9e)

Solvent: $\mathrm{CDCl}$
Frequency. $400.11 \mathrm{MHz}$

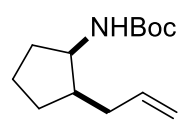

$9 e$

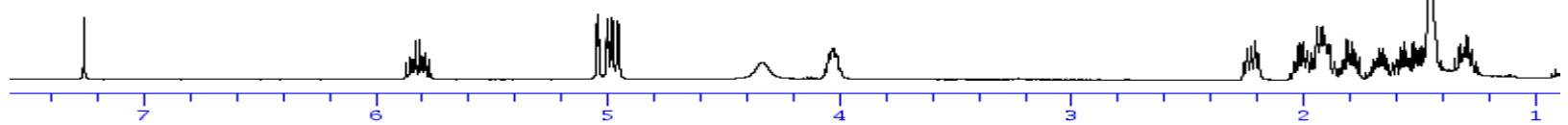

Solvent: $\mathrm{CDCl} 3$
Frequency. $100.61 \mathrm{MHz}$
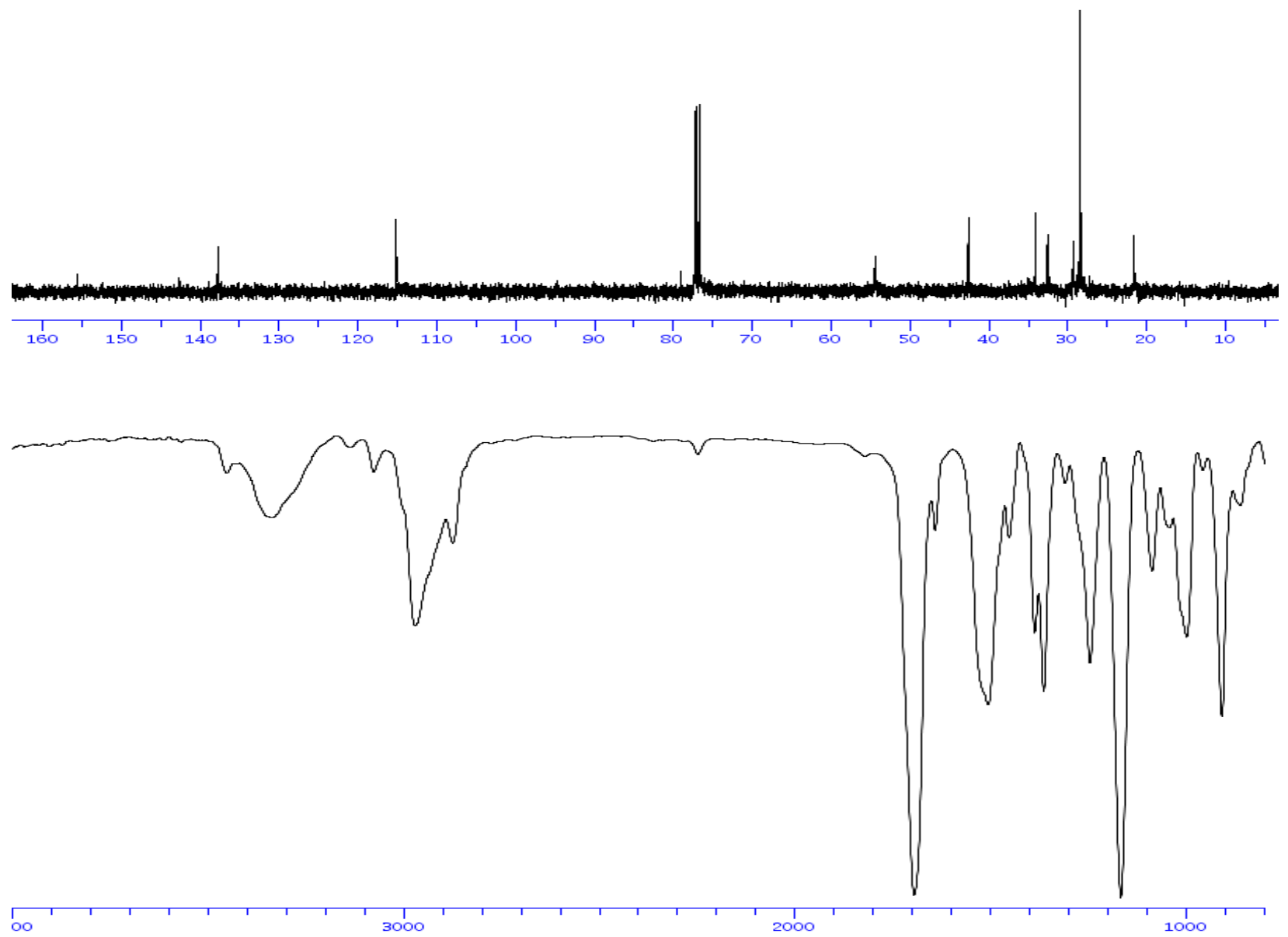
tert-Butyl (2-allylcyclohexyl)carbamate (9f)

Solvent: $\mathrm{CDCI} 3$
Frequency: $400.11 \mathrm{MHz}$

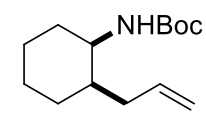

$9 f$

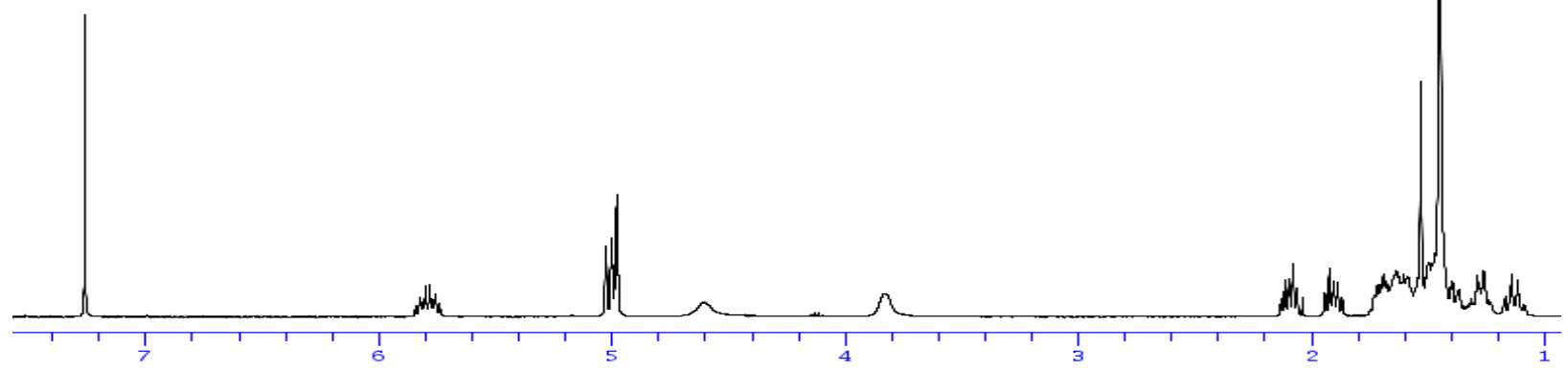

Solvent: $\mathrm{CDCI} 3$

Frequency. $100.61 \mathrm{MHz}$
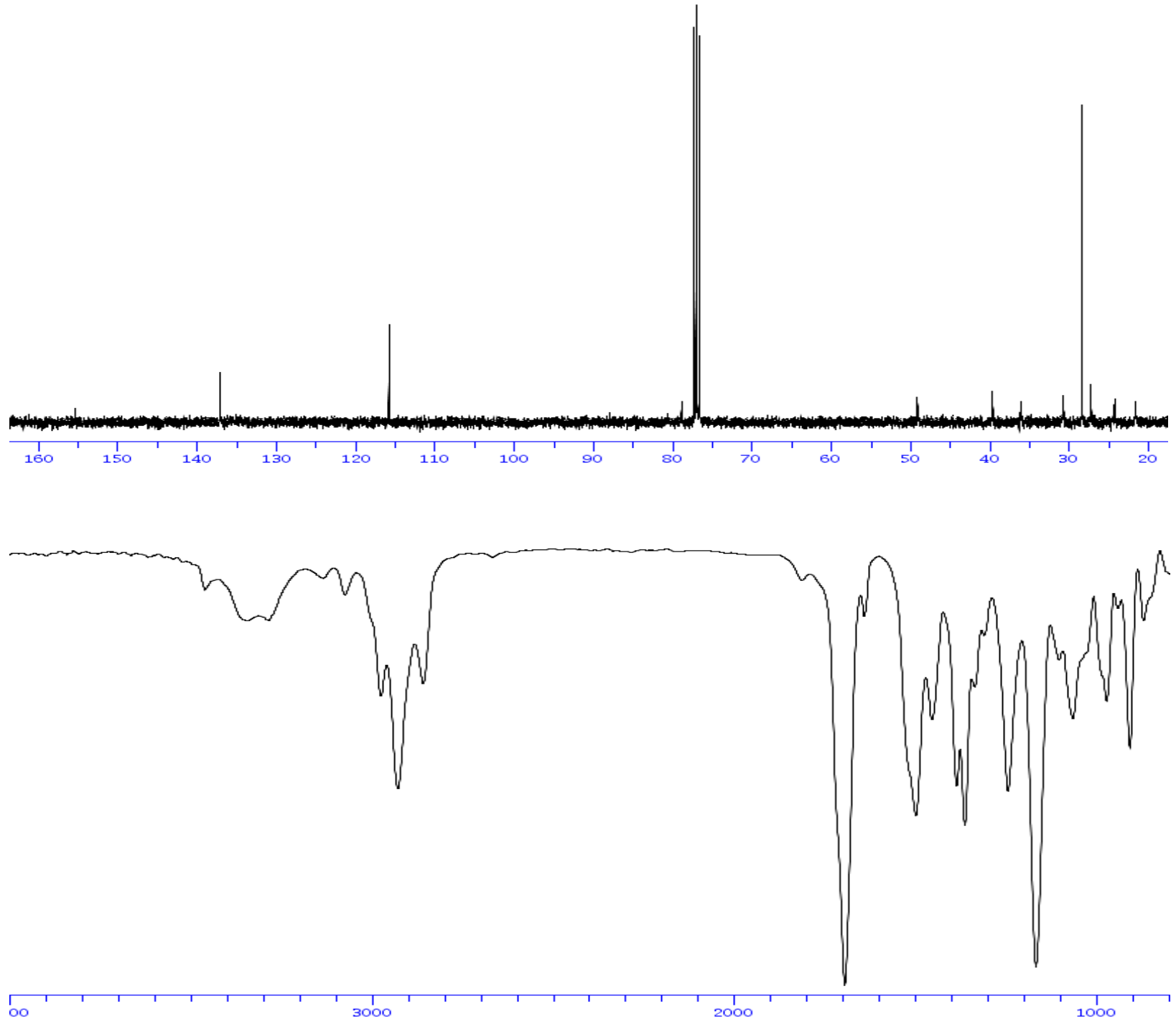


\section{tert-Butyl (2-allylcycloheptyl)carbamate (9g)}

Solvent: $C D C I 3$
FrequencY, $400.11 \mathrm{MHz}$

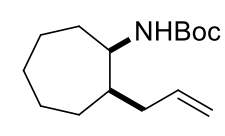

$9 g$

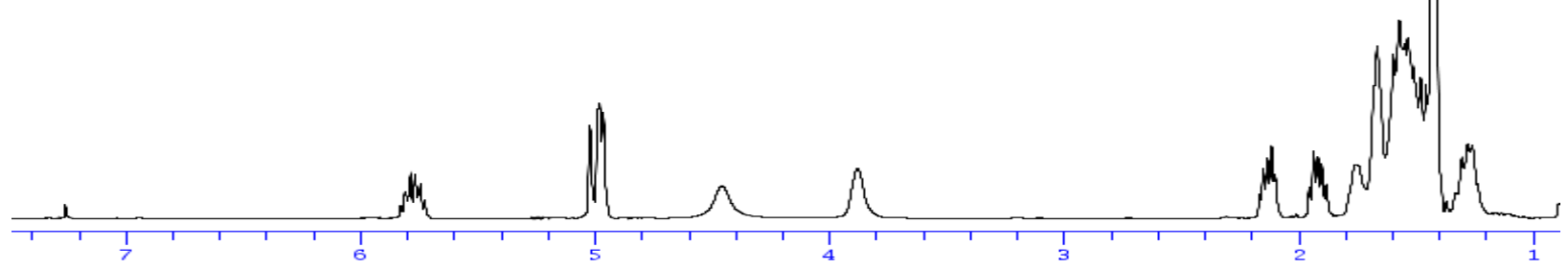

Solvent: $\mathrm{CDCI}$

Frequency. 100.61
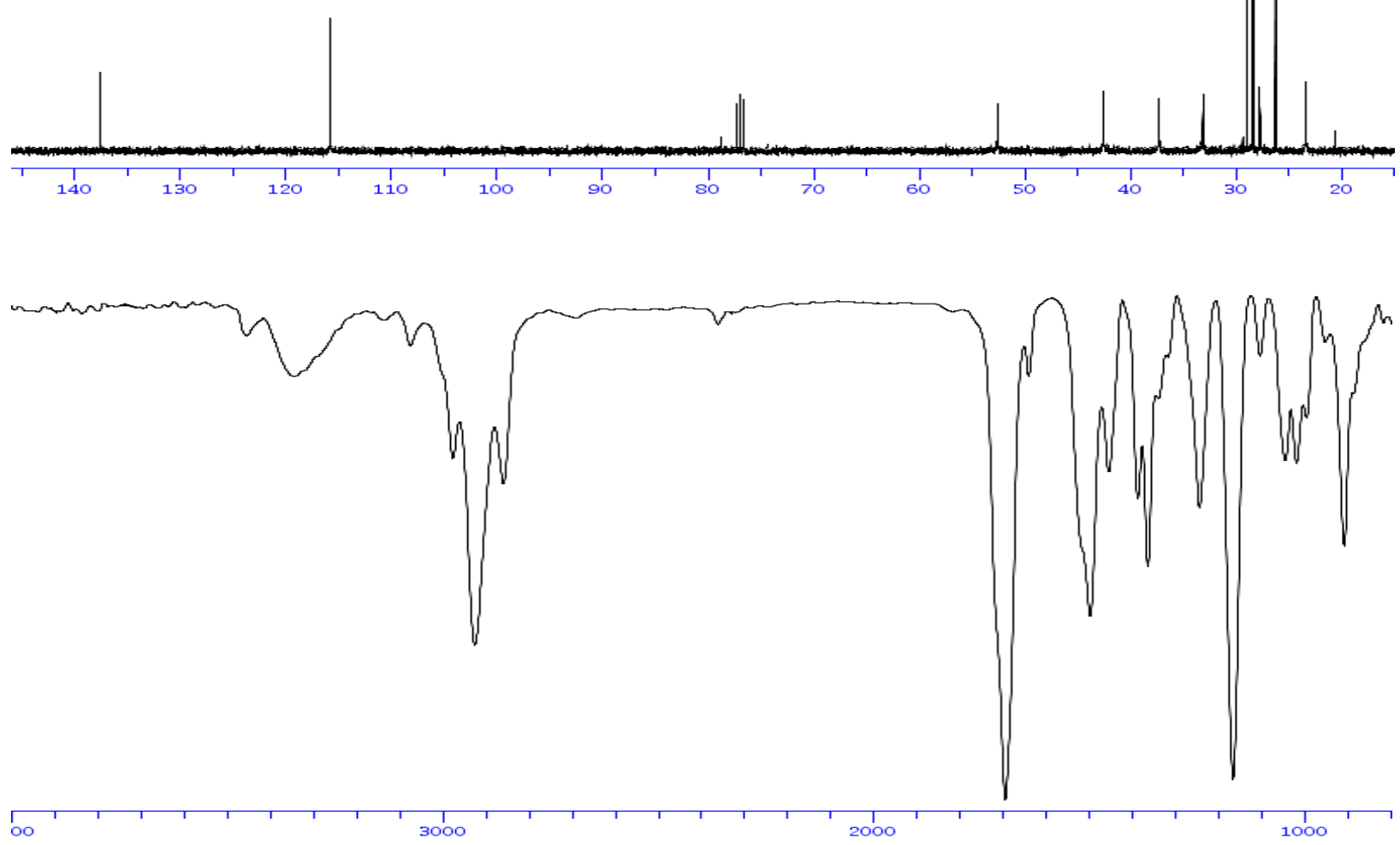


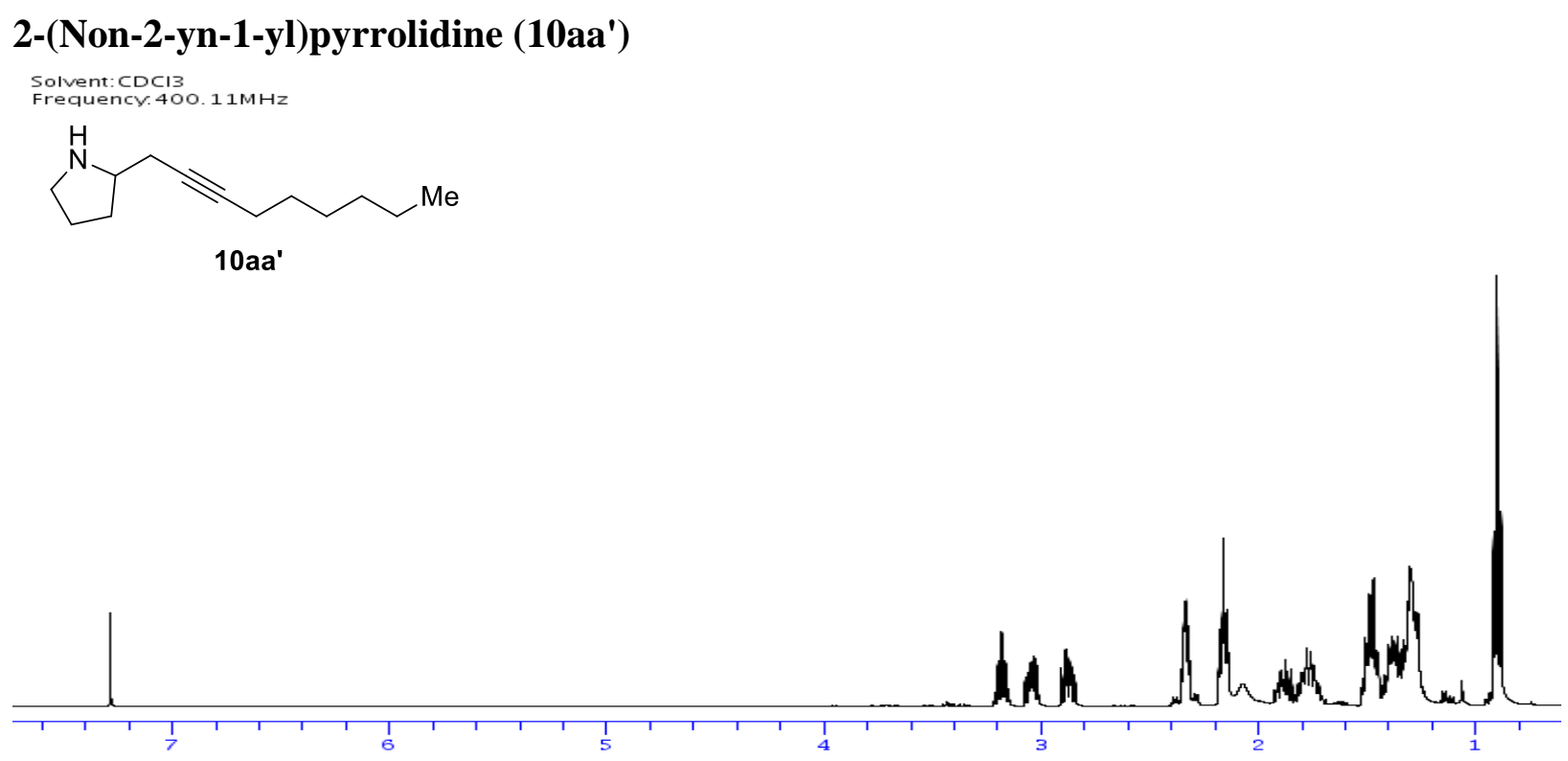

Solvent: CDCI3

Frequency. $100.61 \mathrm{MHz}$
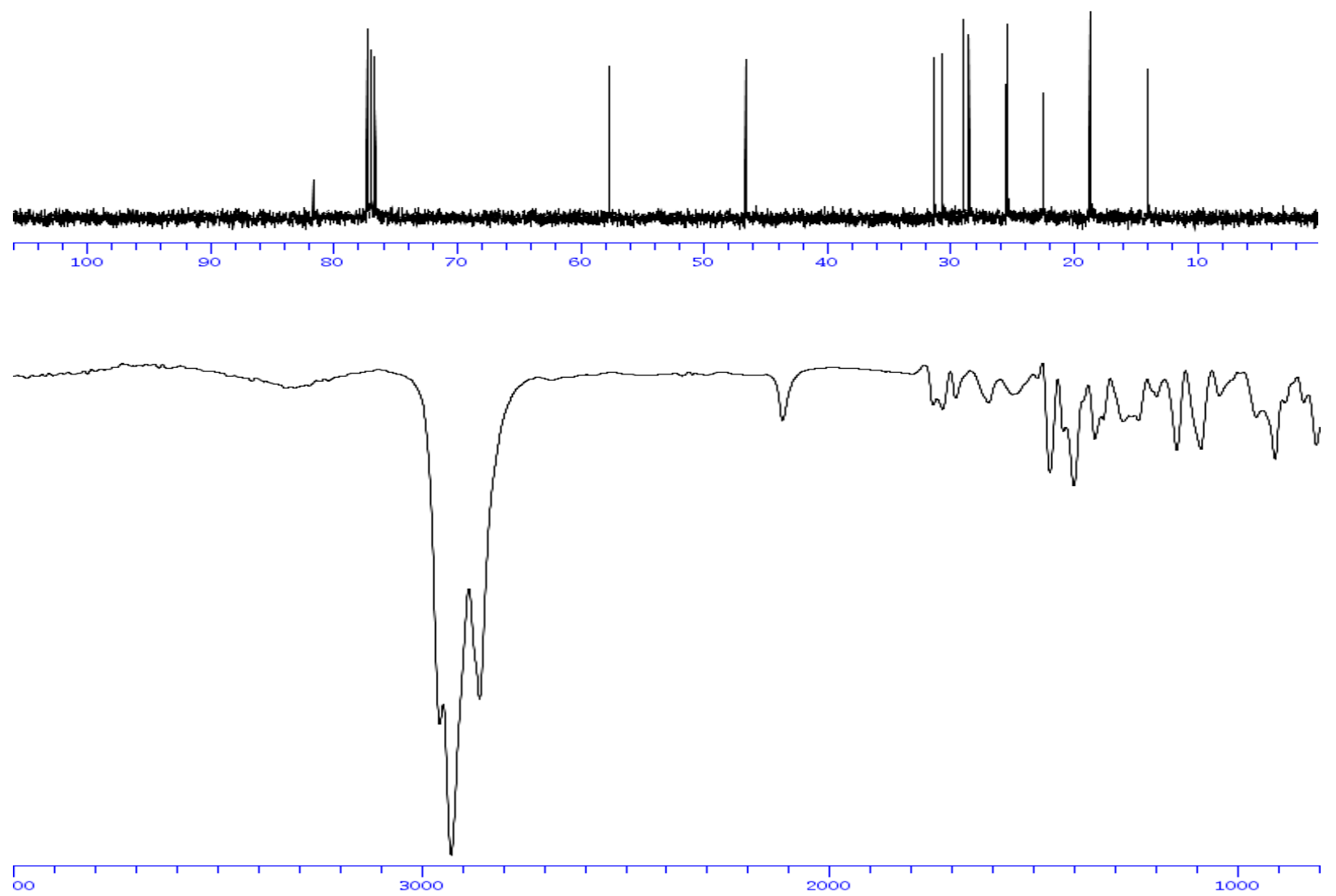


\section{2-(6-((tert-Butyldiphenylsilyl)oxy)hex-2-yn-1-yl)pyrrolidine (10ad')}

Solvent: $\mathrm{CDCI}$

$400.11 \mathrm{MHz}$
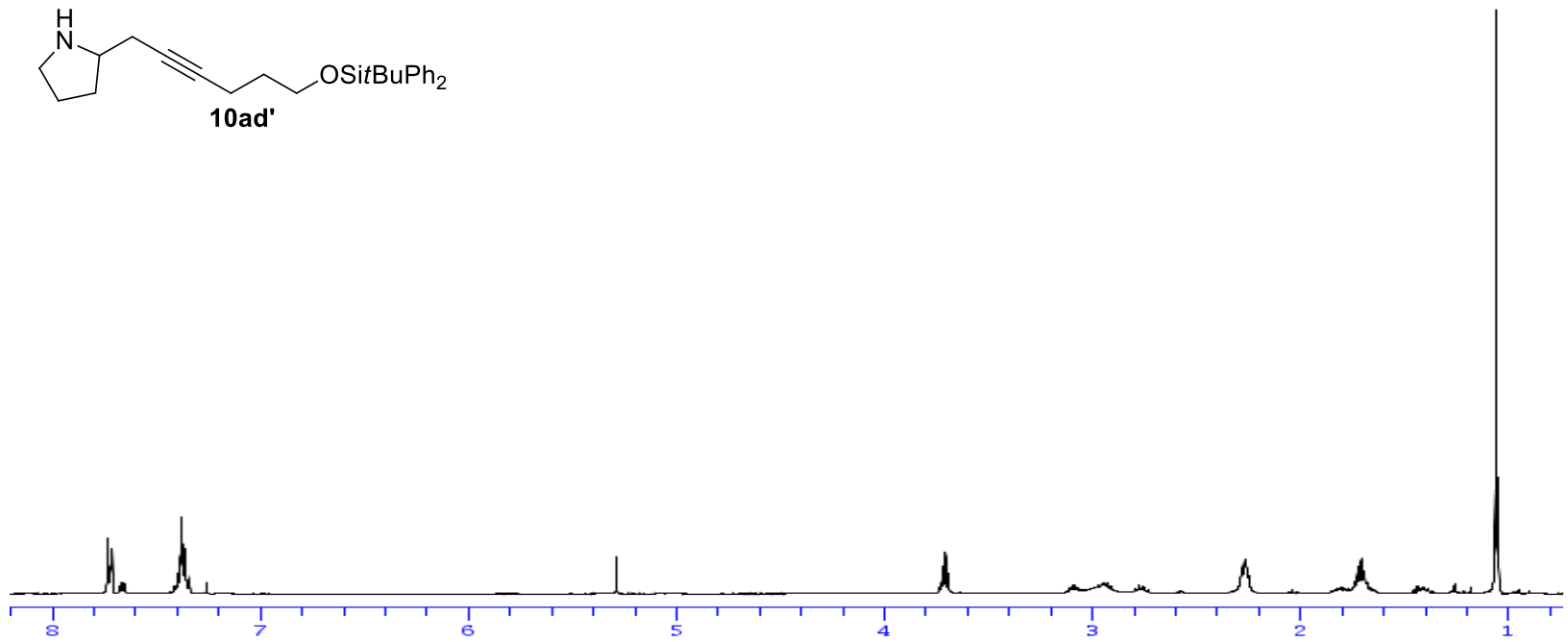

Solvent: CDCI3

Frequency. $100.61 \mathrm{MHz}$
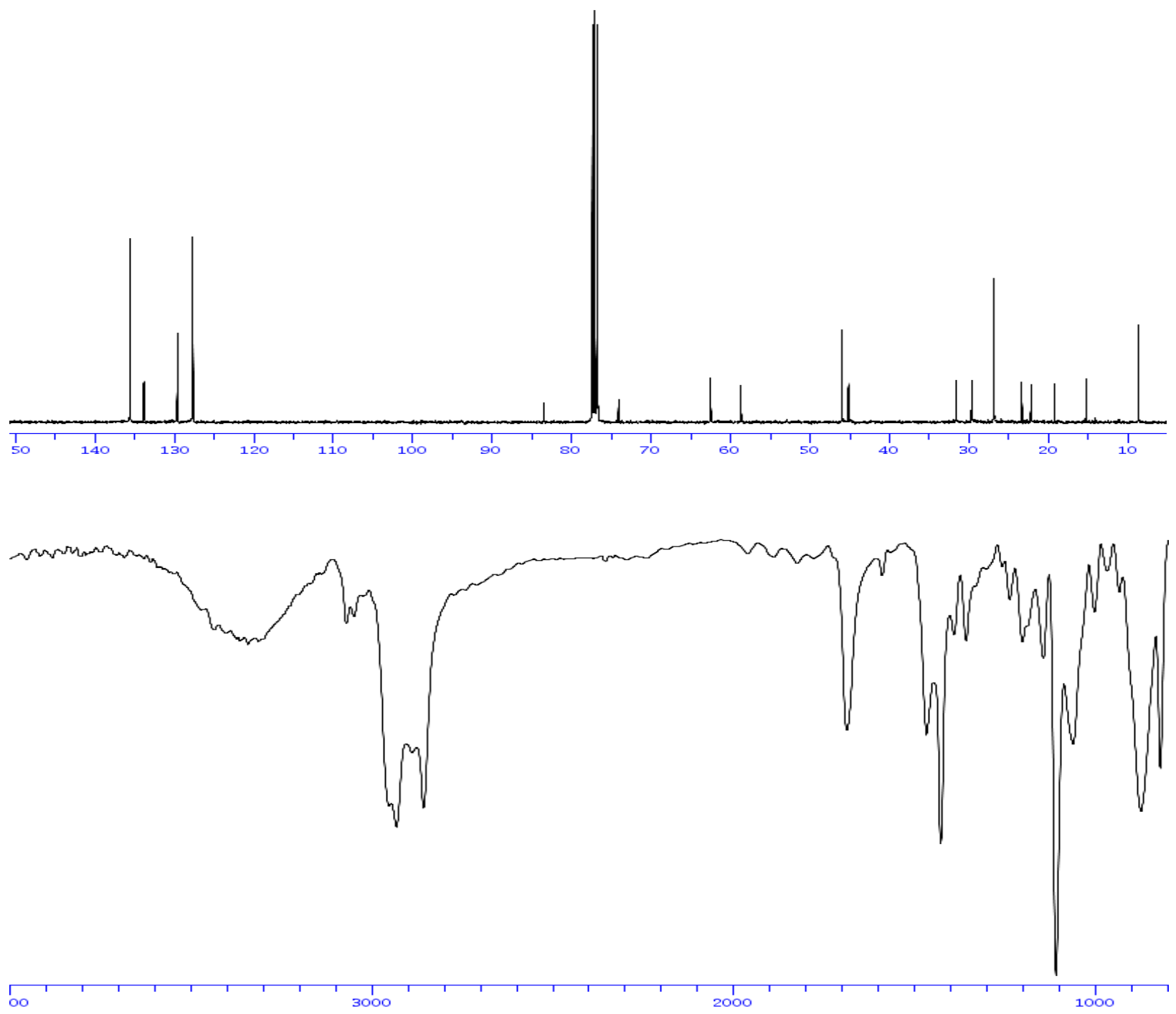

oo 


\section{2-(6-Phenylhex-2-yn-1-yl)pyrrolidine (10ae')}

Solvent: $C D C I 3$
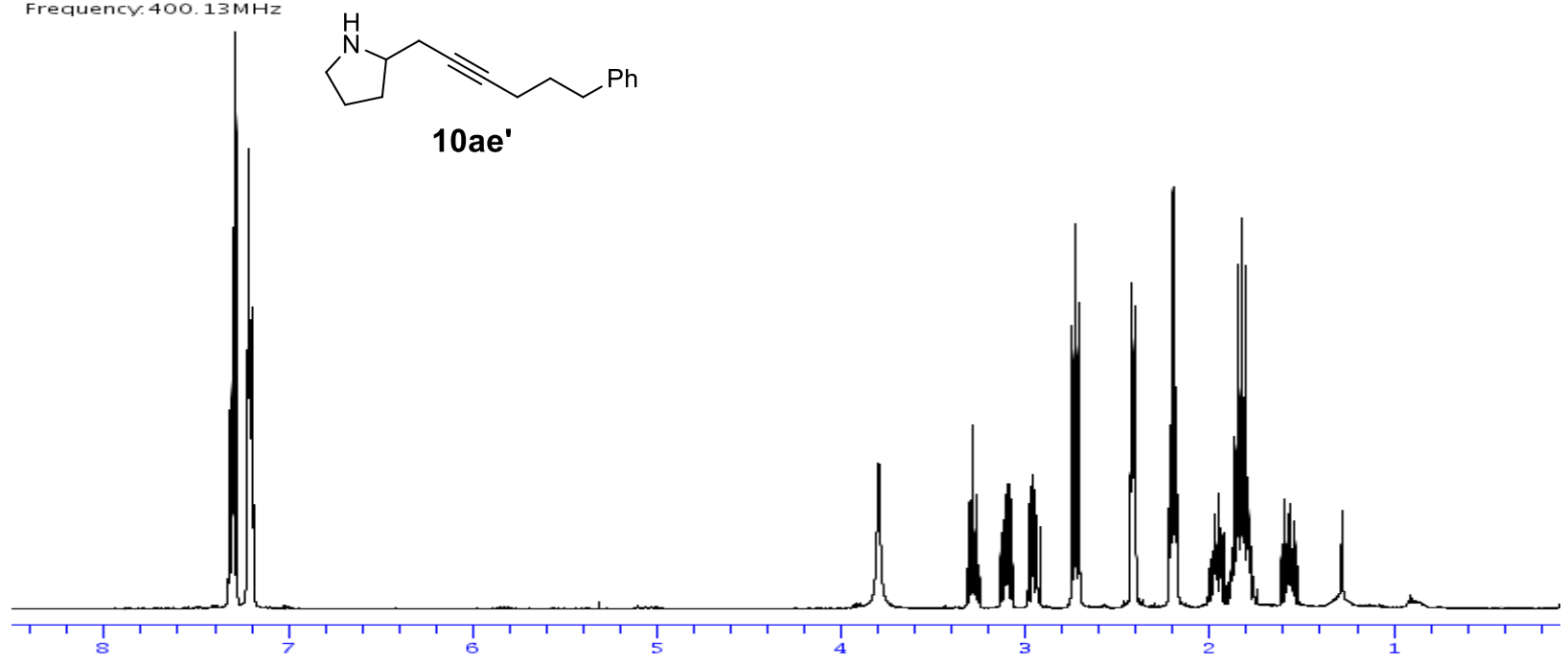

Solvent: $\mathrm{CDCI}$

Frequency $100.61 \mathrm{MHz}$
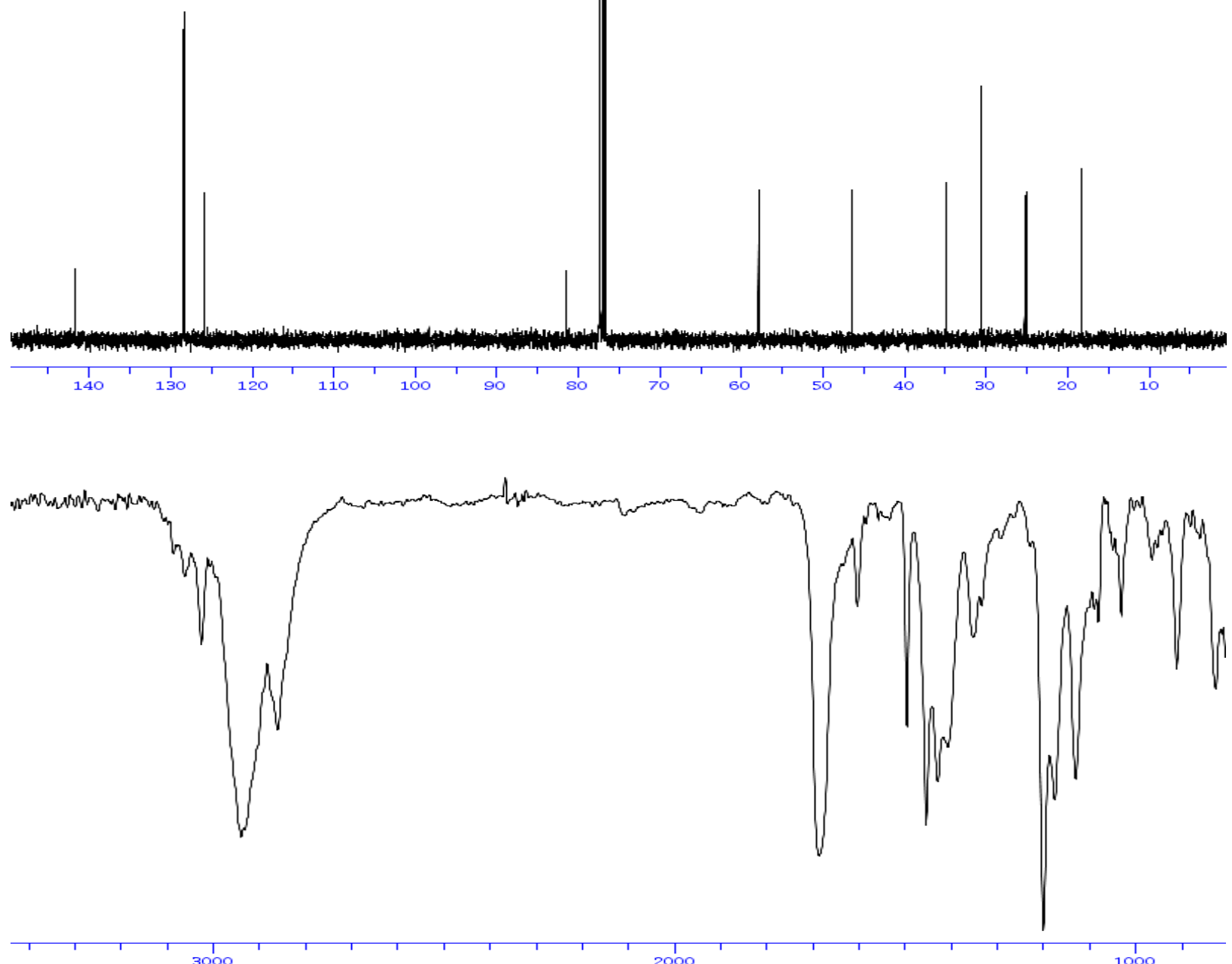
tert-Butyl 2-(4-(benzyloxy)-4-methylpent-2-yn-1-yl)pyrrolidine-1-carboxylate (10ah)

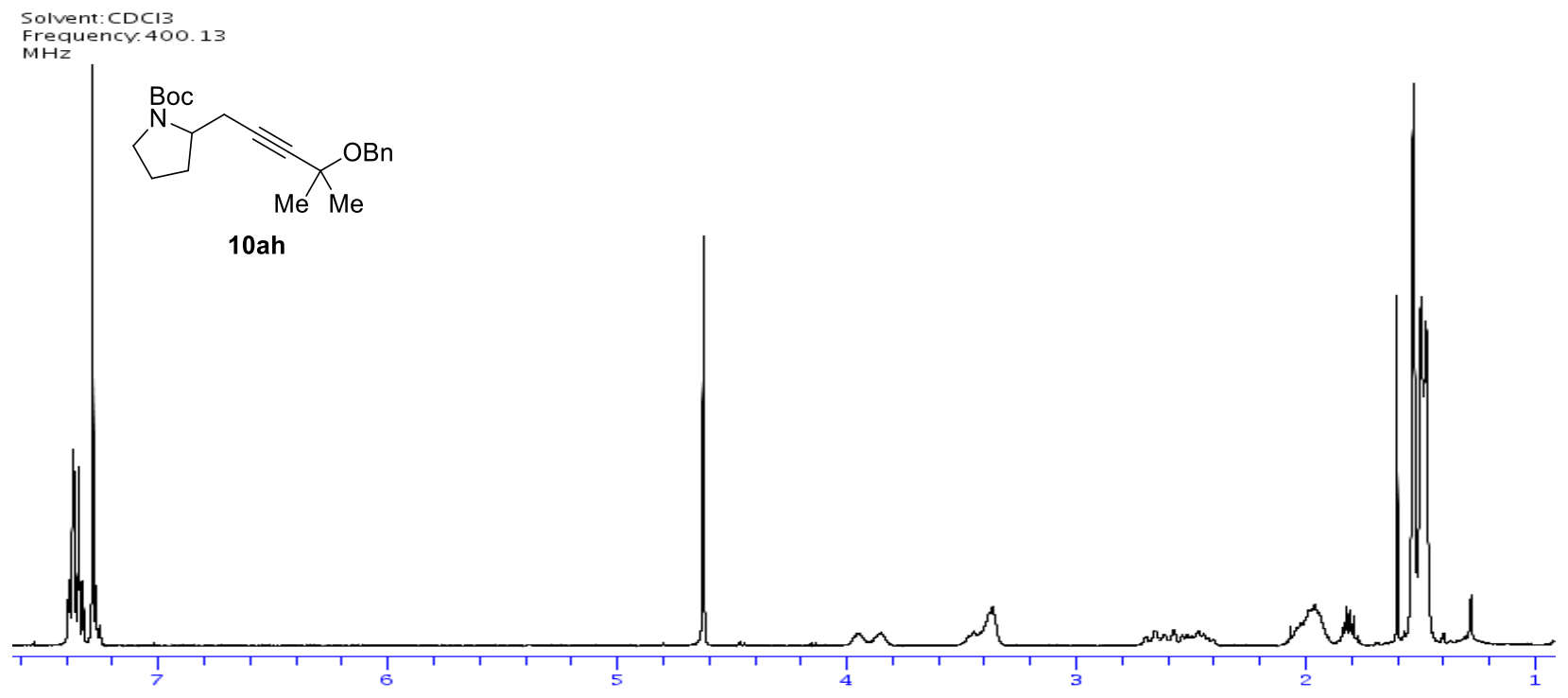

Solvent: $C D C 13$
Frequency.100.61
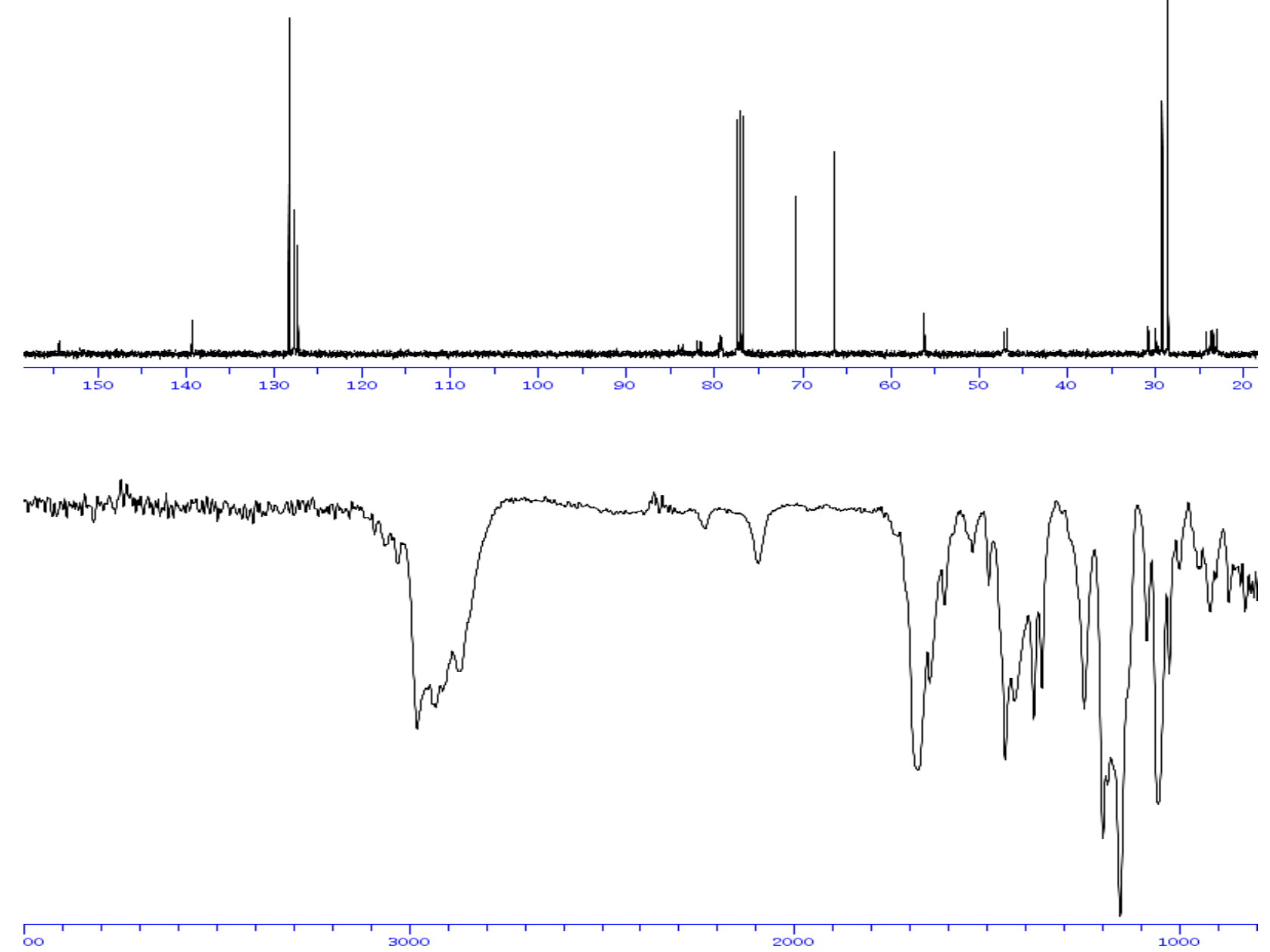
(4-(Benzyloxy)dec-2-yn-1-yl)pyrrolidine (10aj')

Solvent: CDC13

Frequency. 400. $11 \mathrm{MHz}$<smiles>CCCCCCC(C#CCC1CCCN1)Oc1ccccc1</smiles>

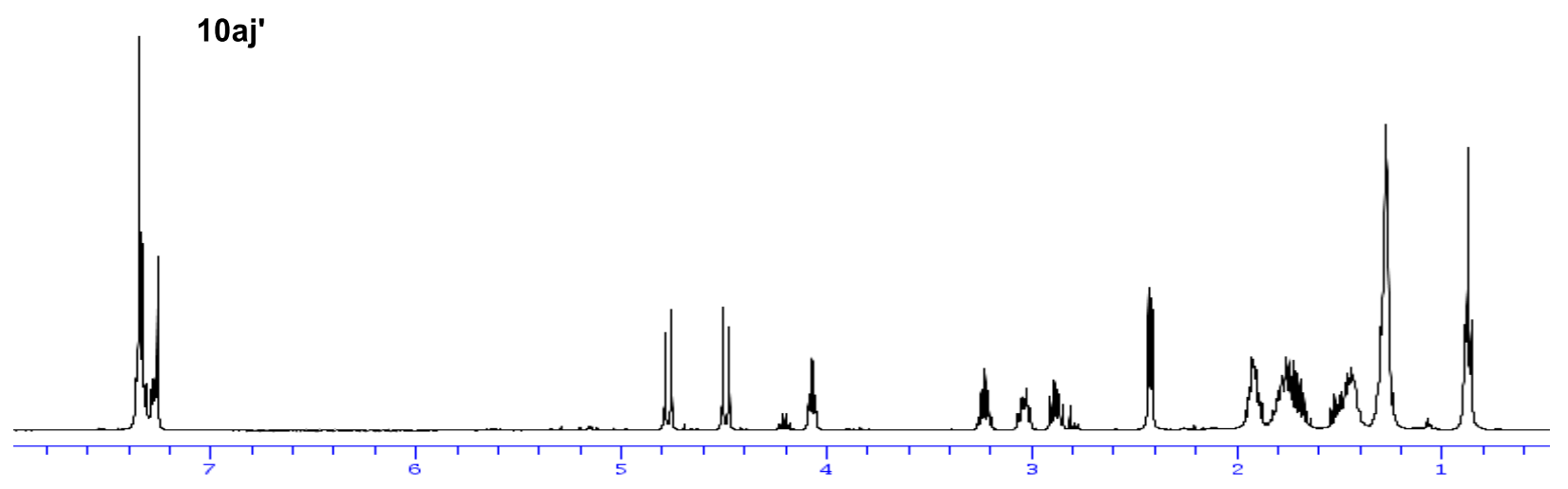

Solvent: $\mathrm{CDCI3}$

. $100.61 \mathrm{MHz}$
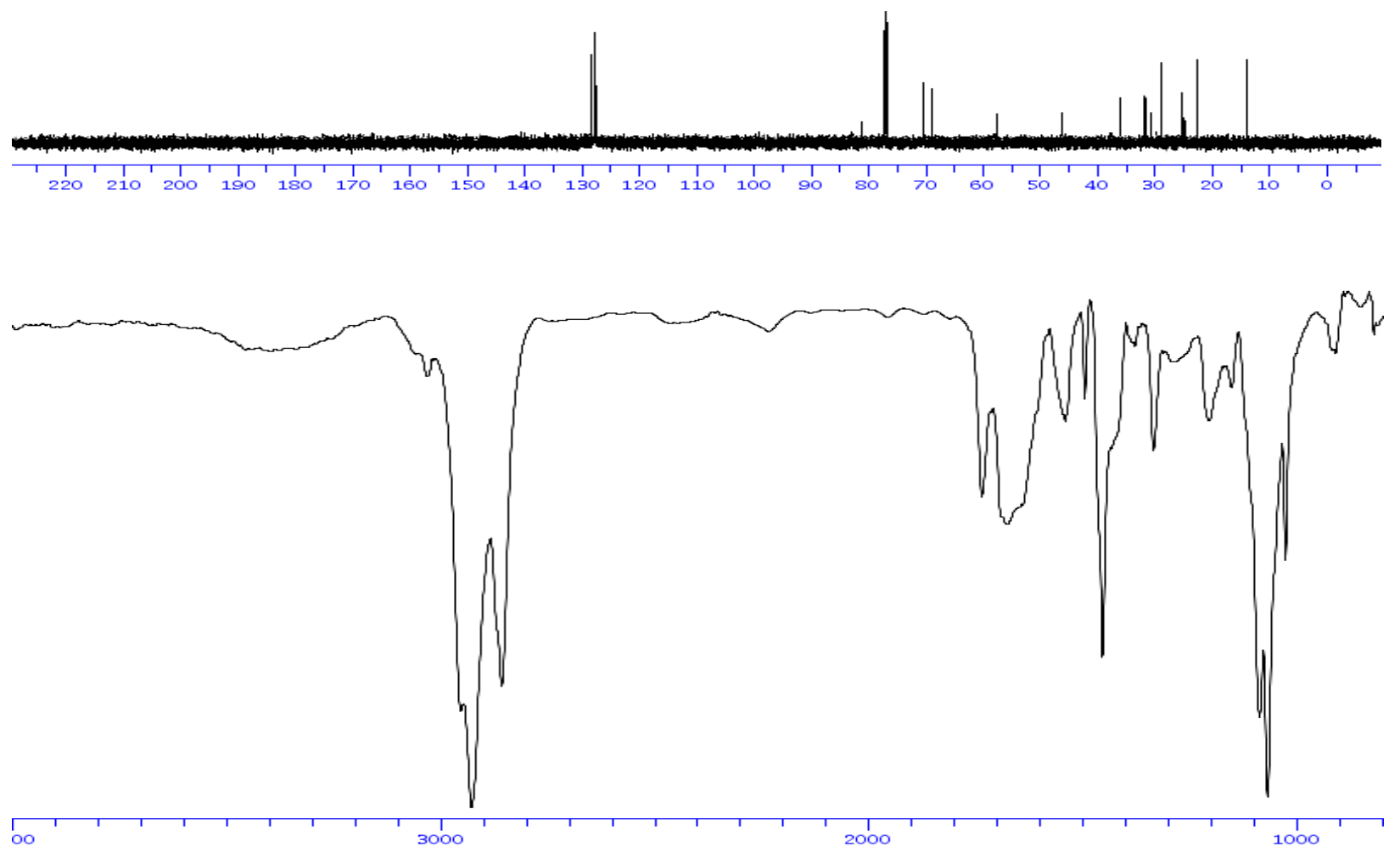
2-(Non-2-yn-1-yl)-5-phenylpyrrolidine (10ba')

Solvent: $C D C I 3$
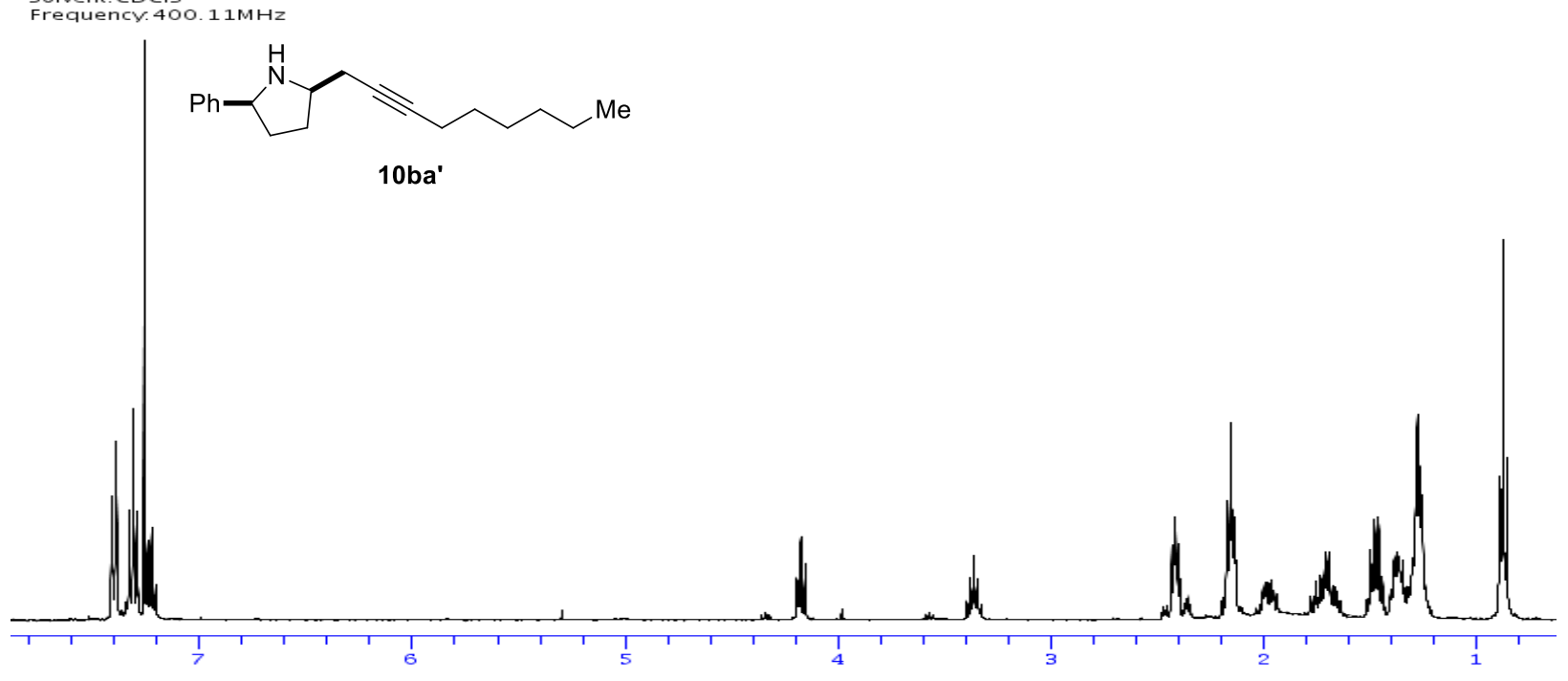

Solvent: $C D C I 3$
Frequency. $100.61 \mathrm{MHz}$
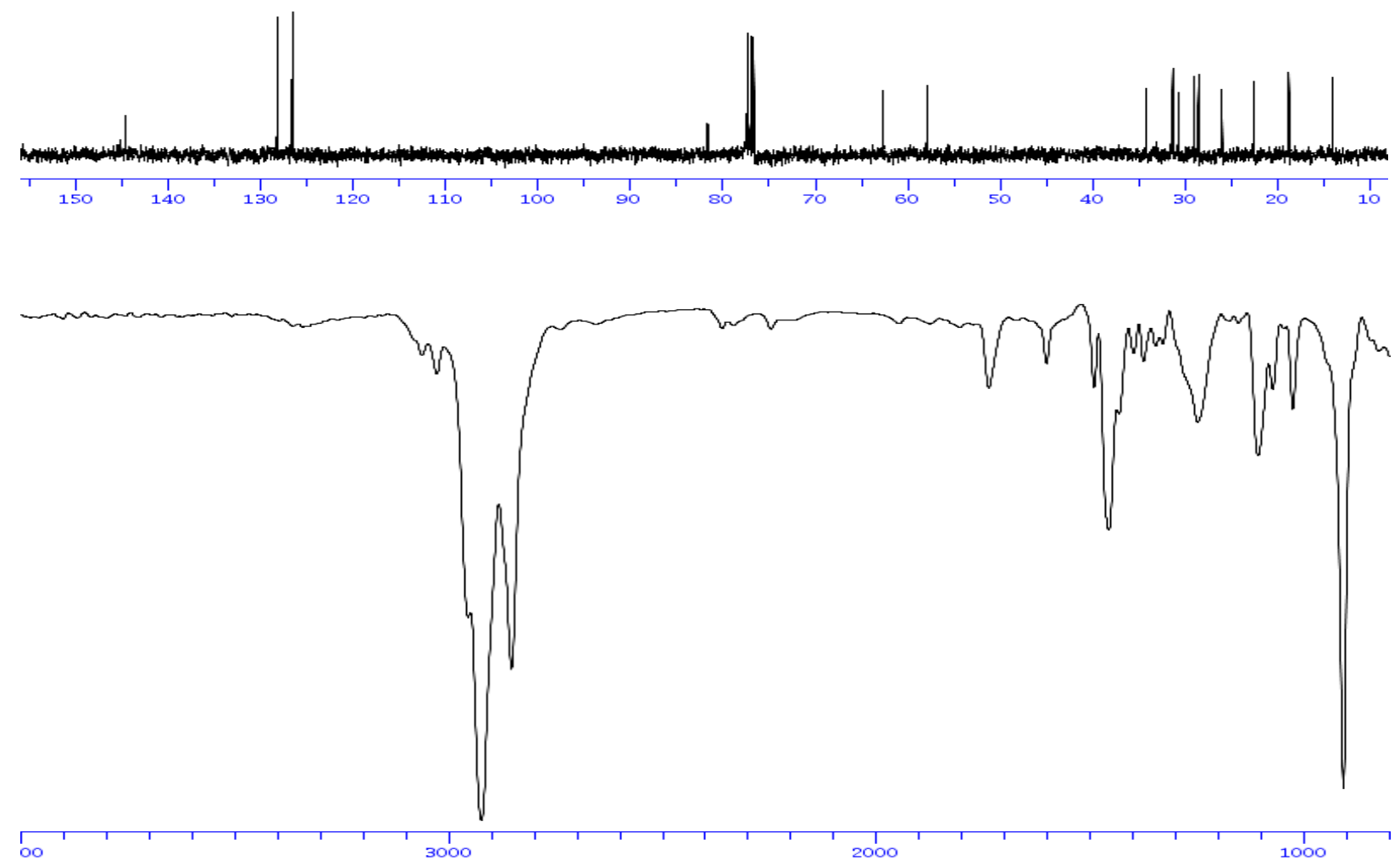

S44 
2-Heptyl-5-(non-2-yn-1-yl)pyrrolidine (10ca')

Solvent: $\mathrm{CDC13}$

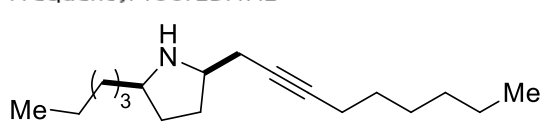

10ca'

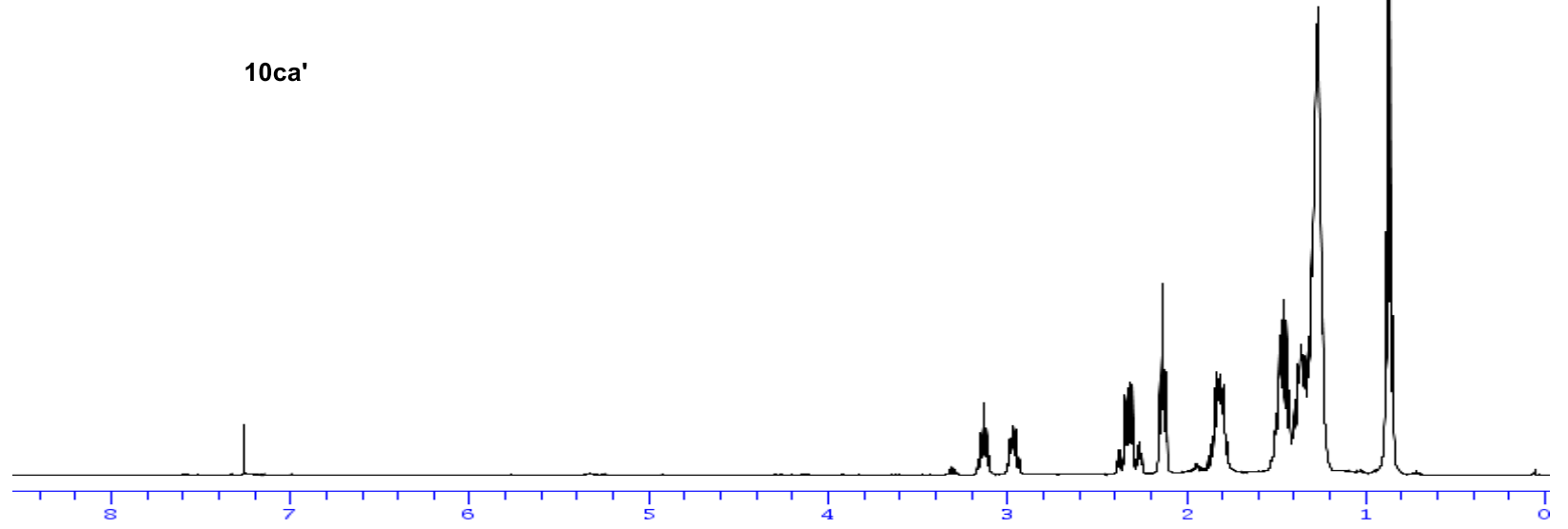

Solvent: $\mathrm{CDCI} 3$

Frequency.100. $11 \mathrm{MHz}$
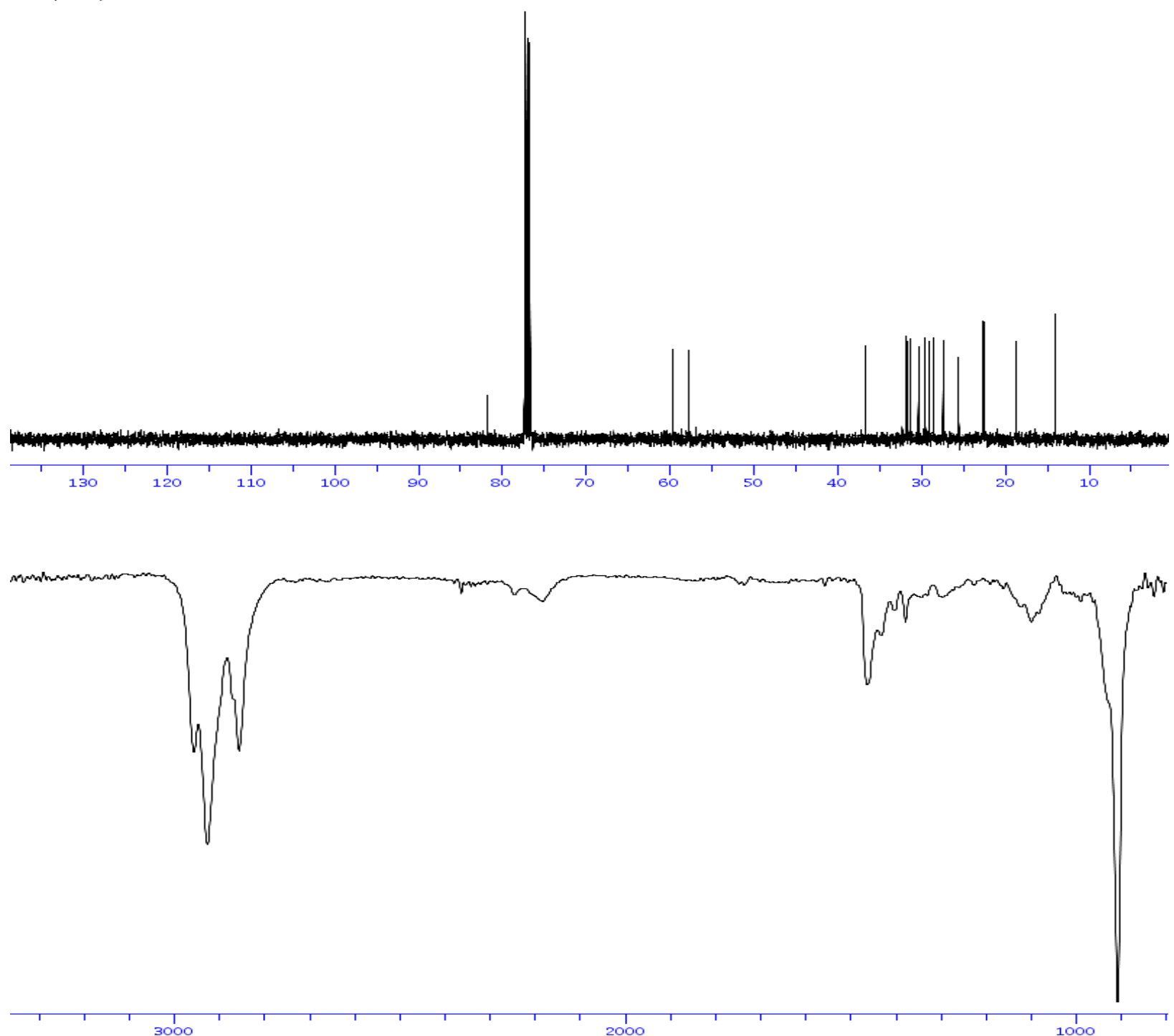


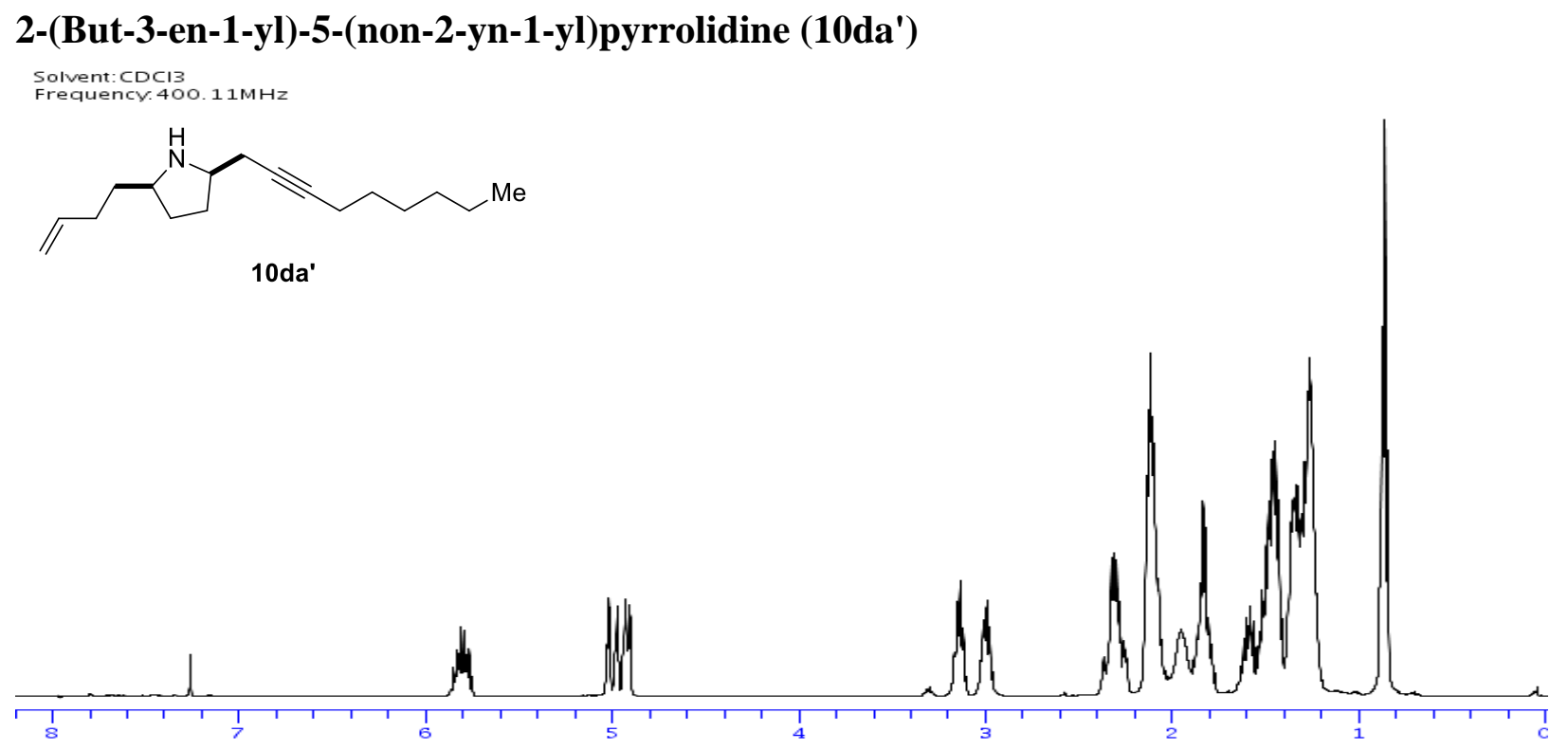

Solvent: $\mathrm{CDCI} 3$

Frequency. $100.61 \mathrm{MHz}$
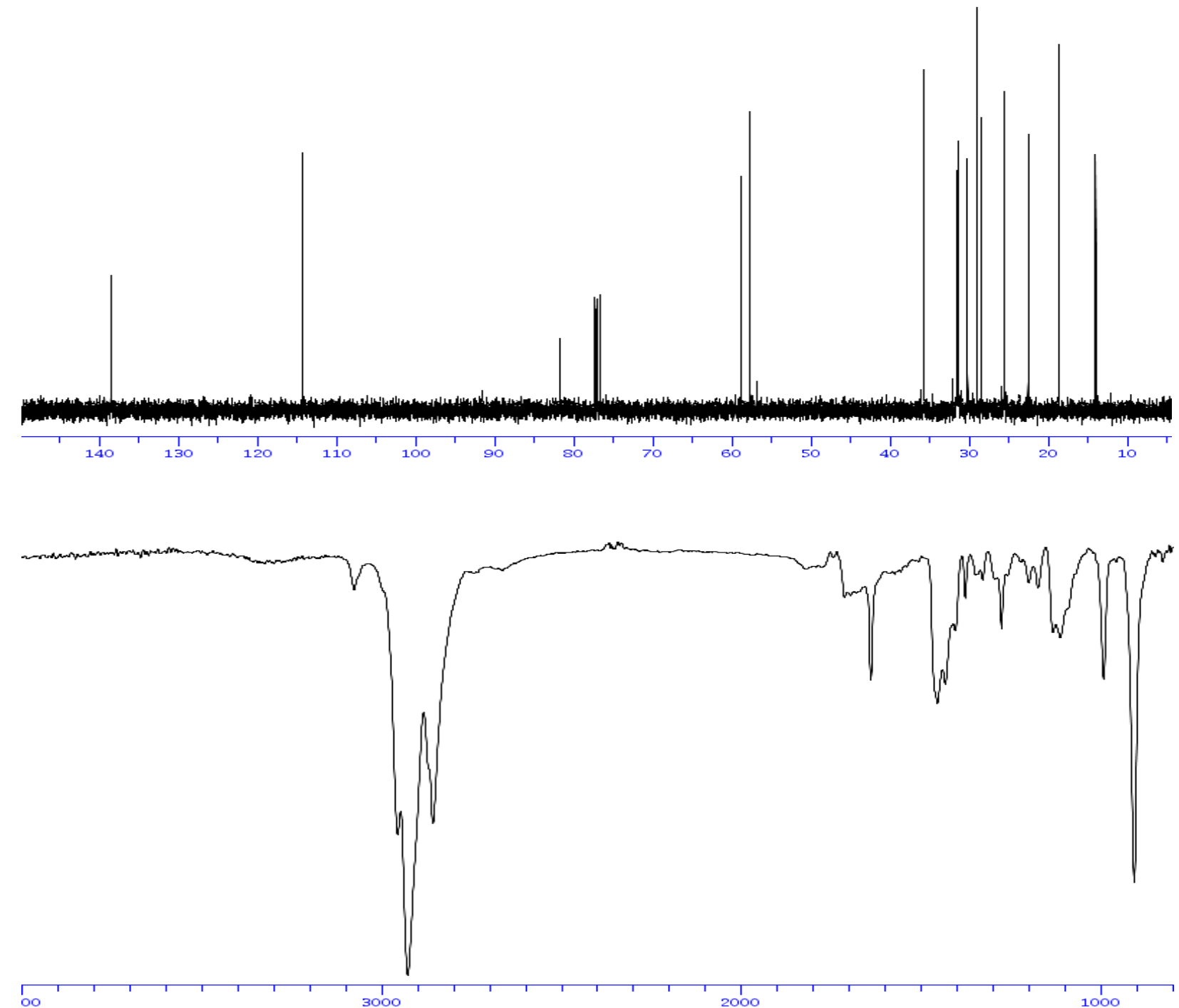
2-(Non-2-yn-1-yl)octahydrocyclopenta[b]pyrrole (10ea')

Solvent: $C D C I 3$

$.11 \mathrm{MHz}$
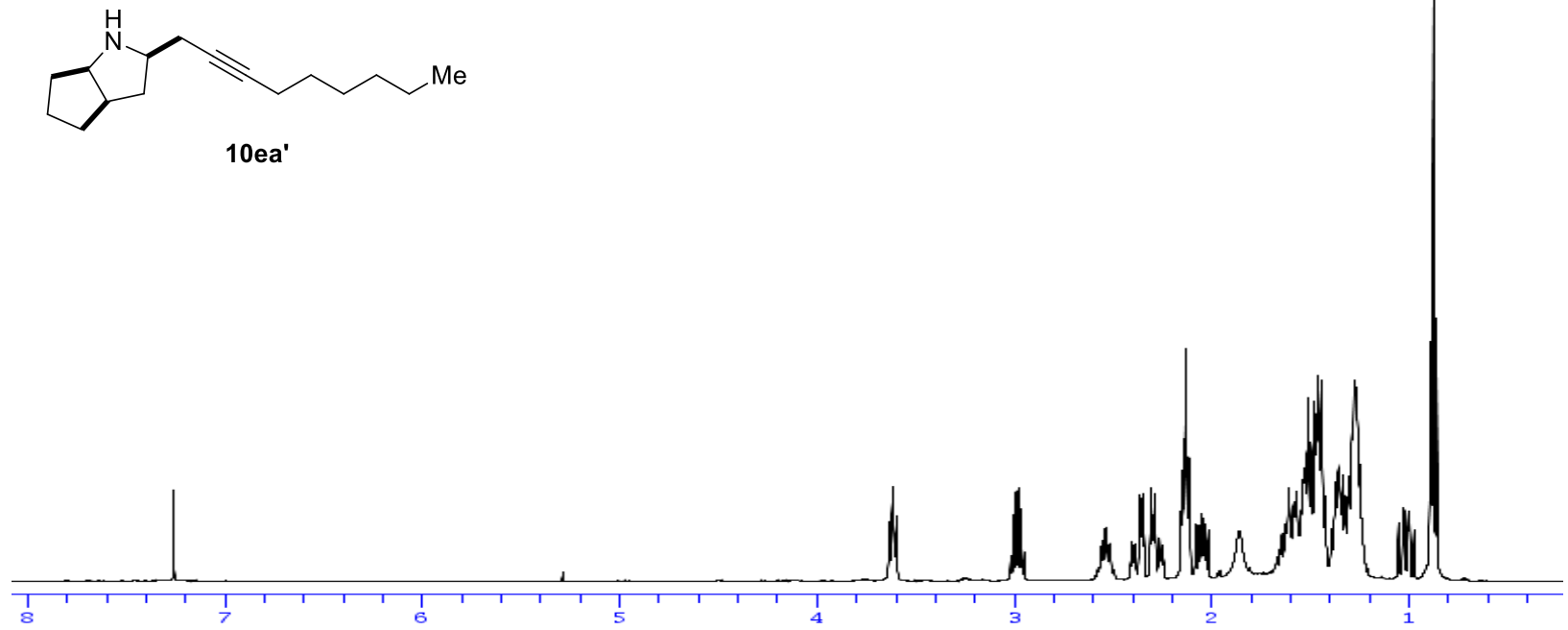

Solvent: $C D C I 3$
Frequency. $100.61 \mathrm{MHz}$
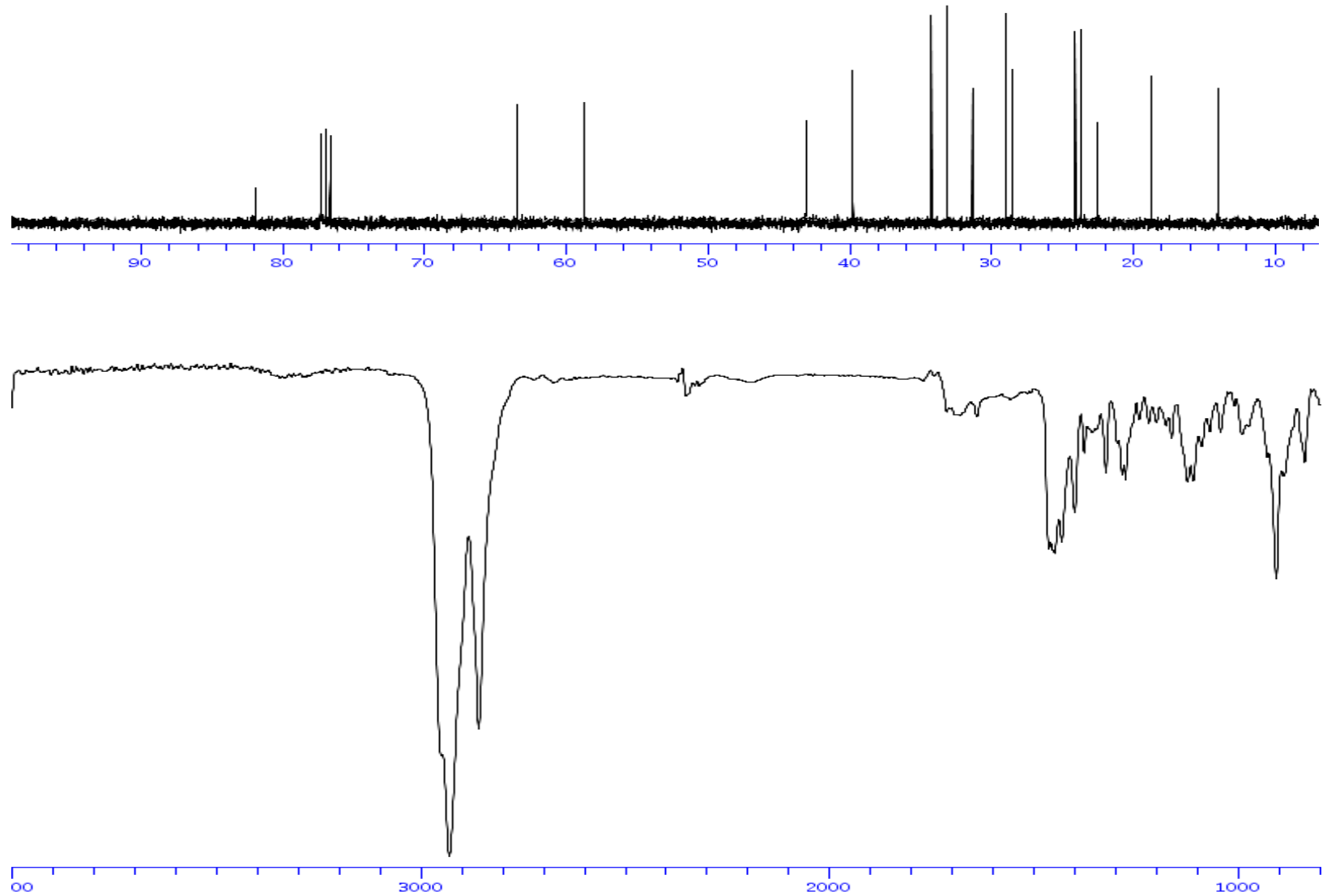
2-(Non-2-yn-1-yl)octahydro-1H-indole (10fa')
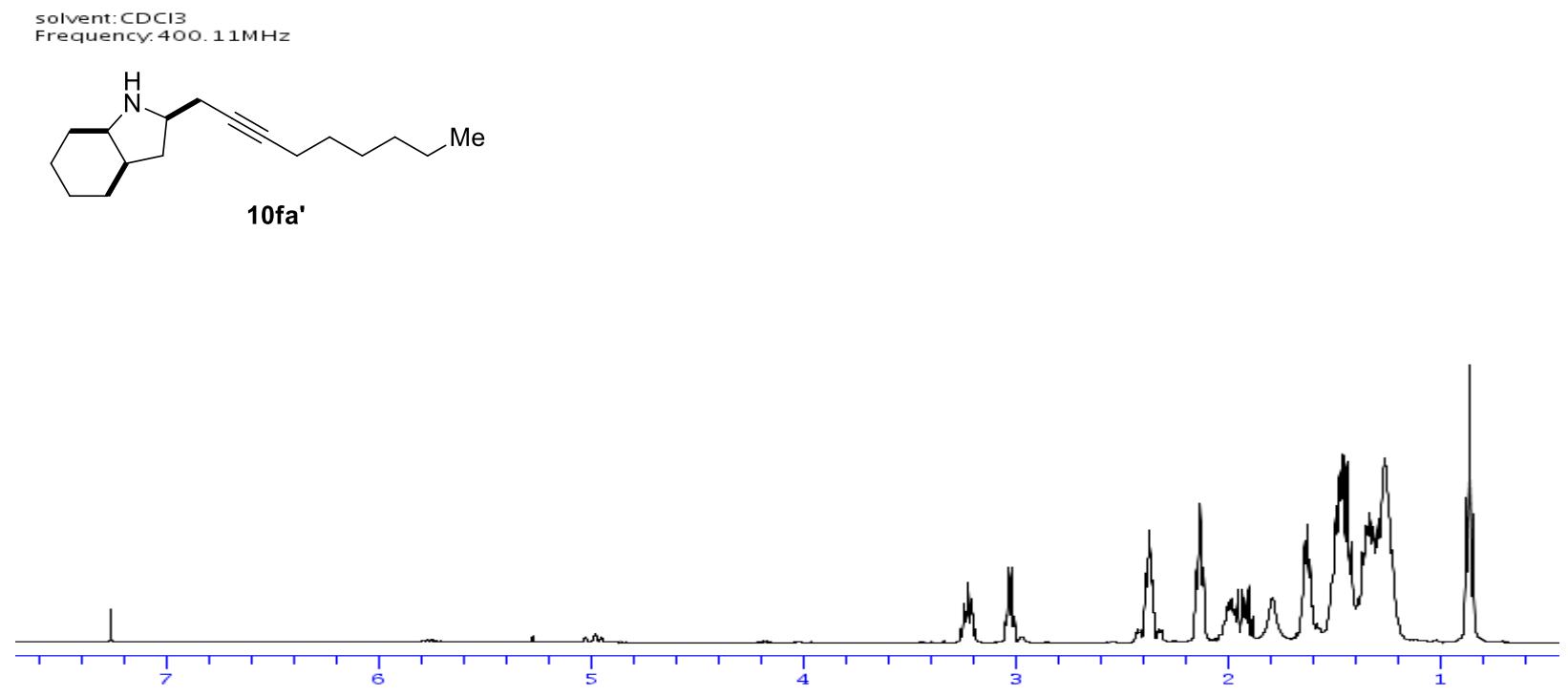

\section{Solvent: $C D C I 3$}
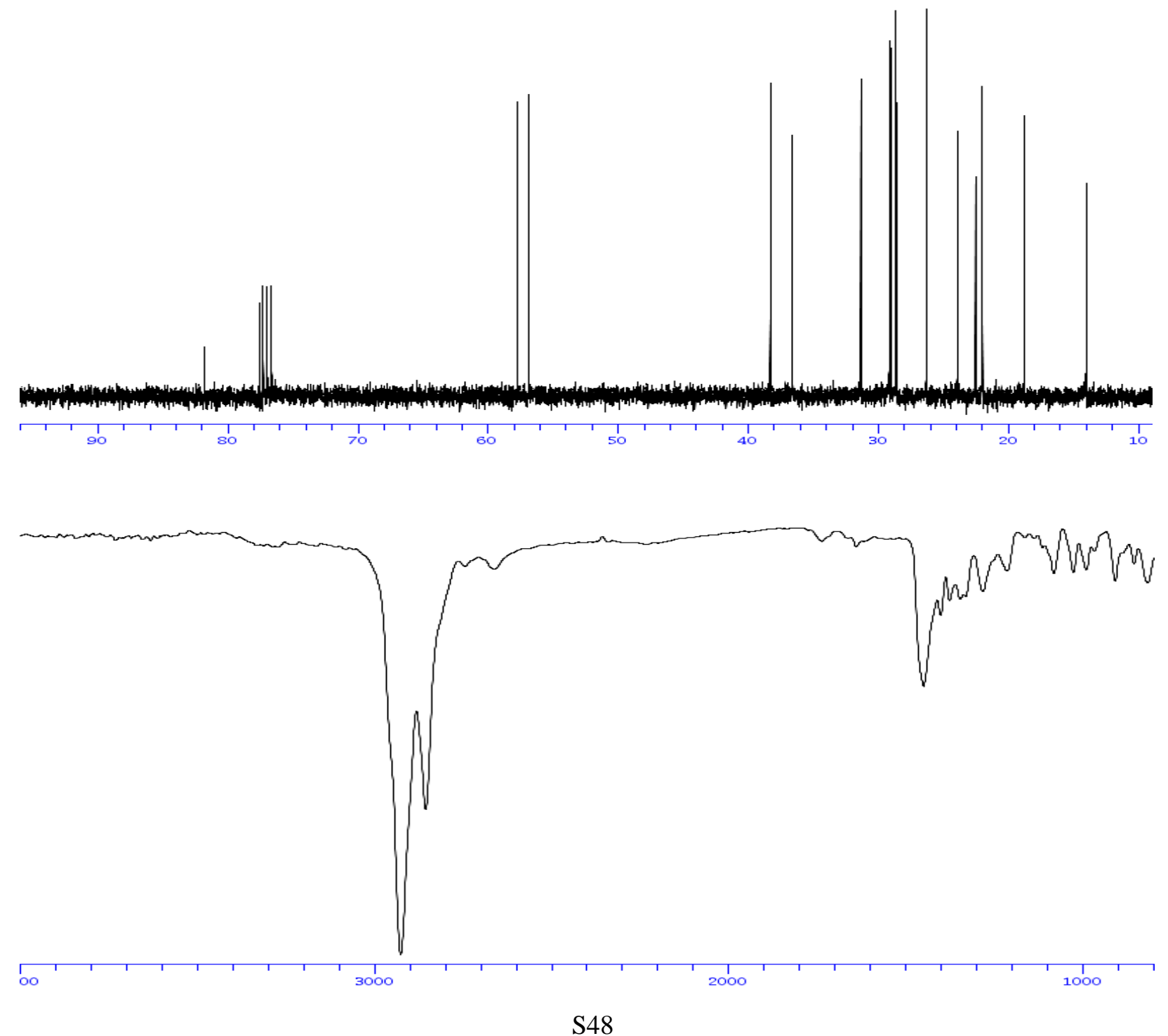
tert-Butyl 2-(10-bromodec-2-yn-1-yl)octahydro-1H-indole-1-carboxylate (10fl) Ssolvent: $C D C I 3$
Frequency. $400.11 \mathrm{MHz}$
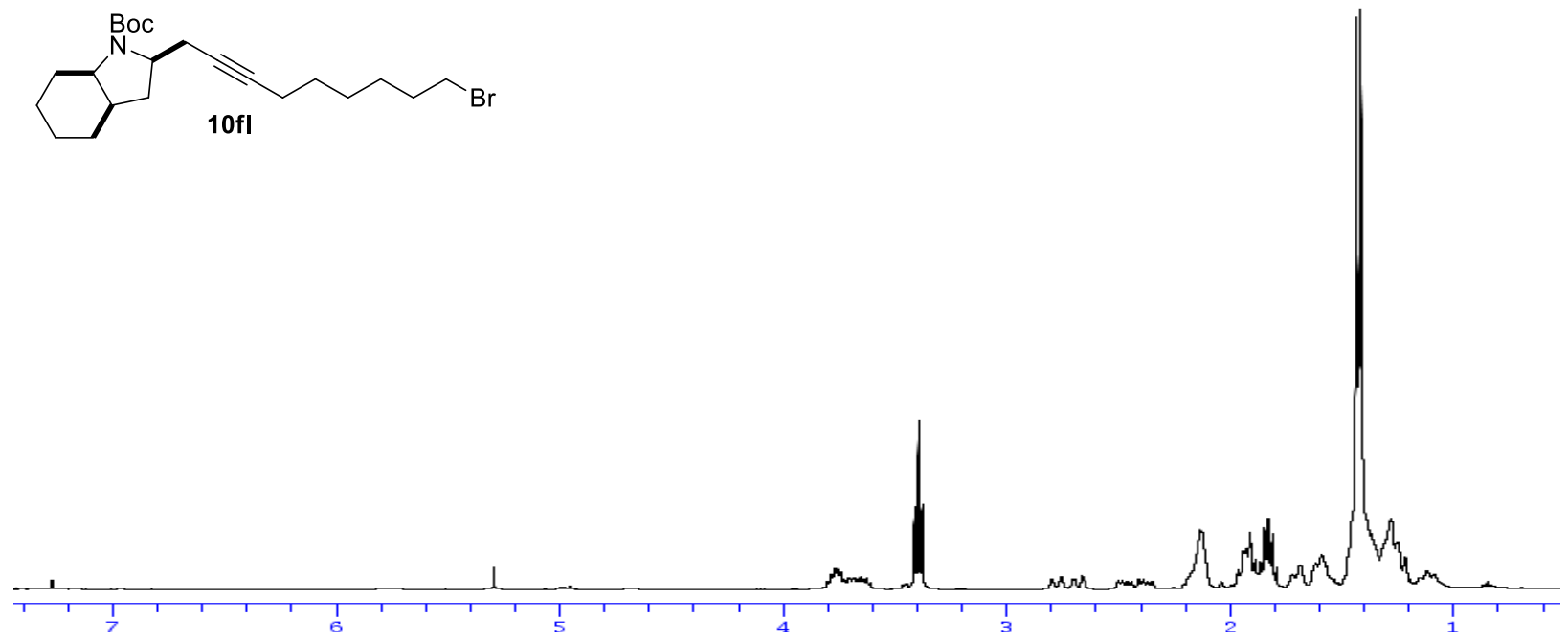

Solvent: $C D C I 3$
Frequency. $100.61 \mathrm{MHz}$
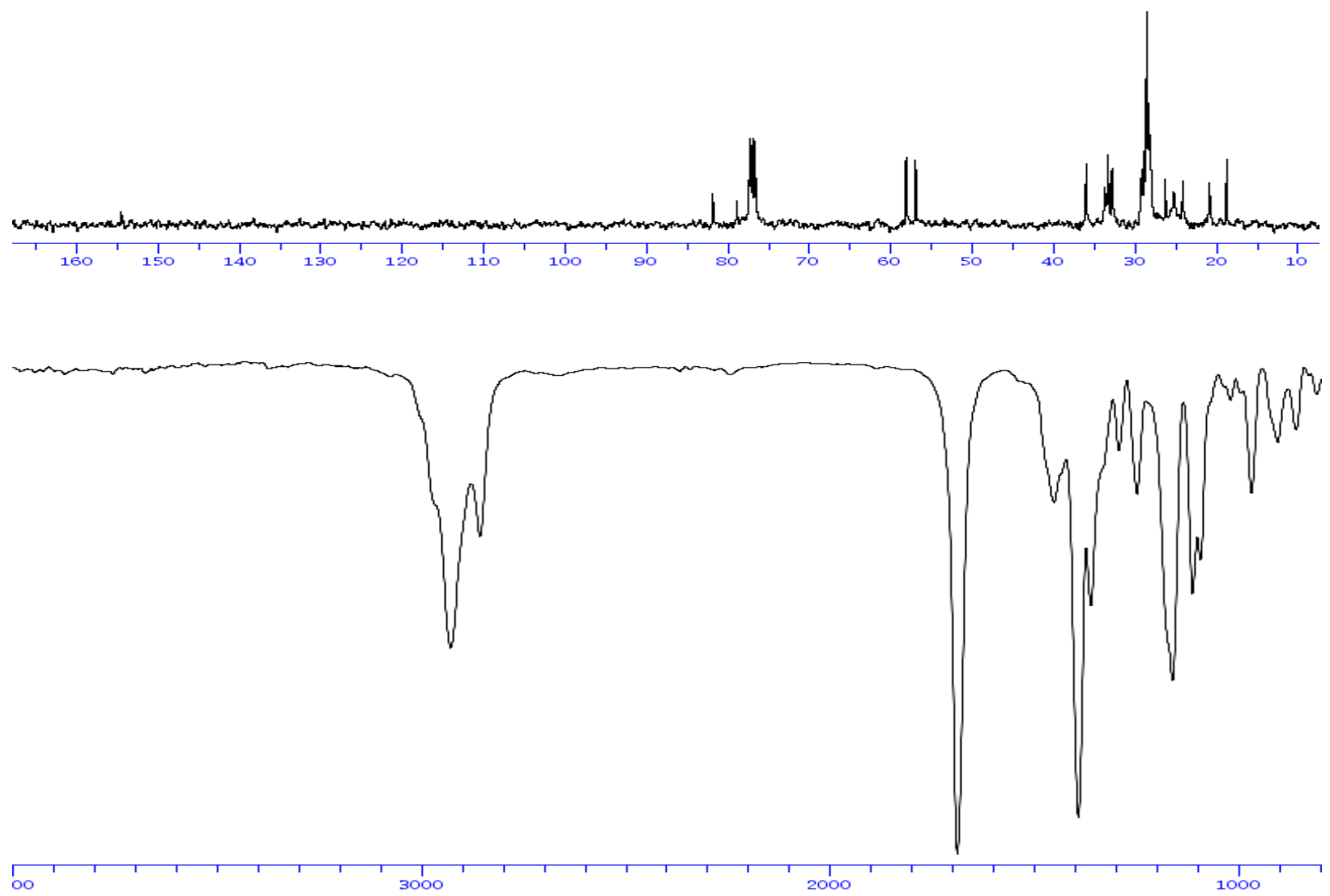


\section{2-(Non-2-yn-1-yl)decahydrocyclohepta[b]pyrrole (10ga')}

Solvent: $C D C I 3$
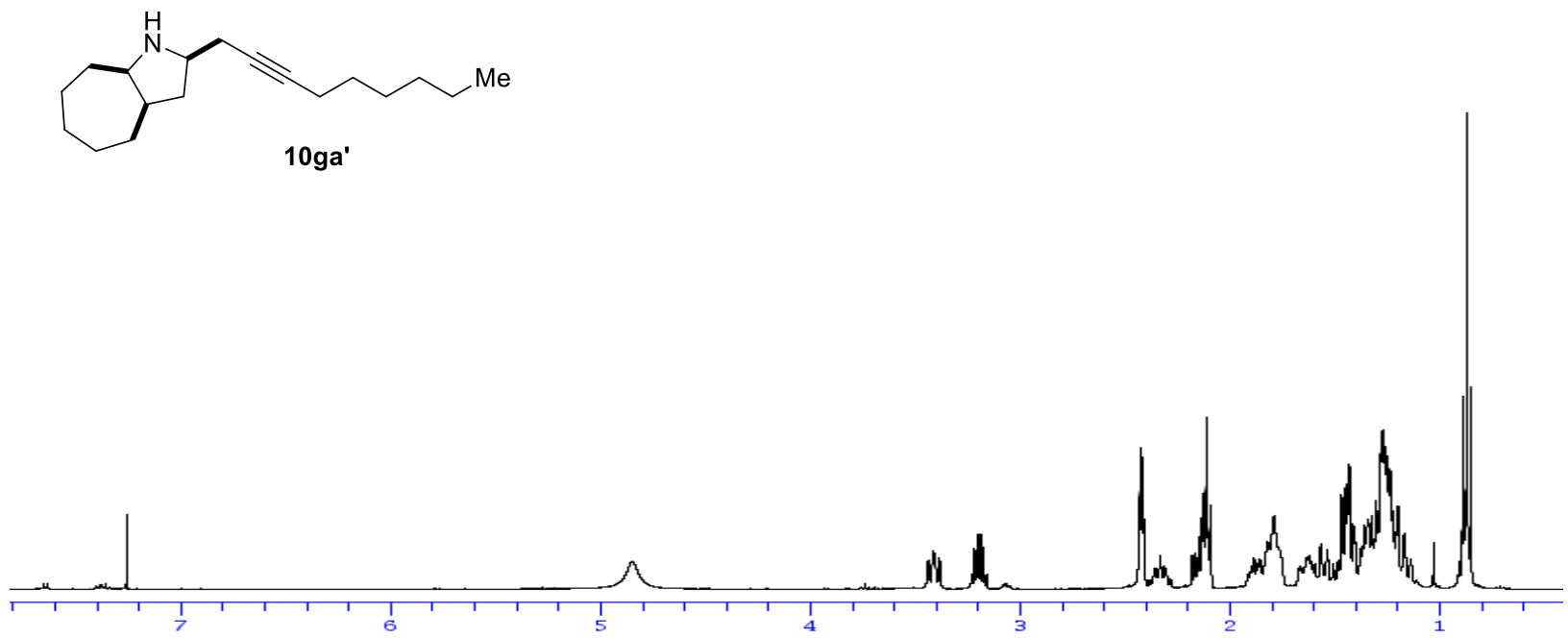

Solvent: $\mathrm{CDCI3}$

Frequency. $100.61 \mathrm{MHz}$
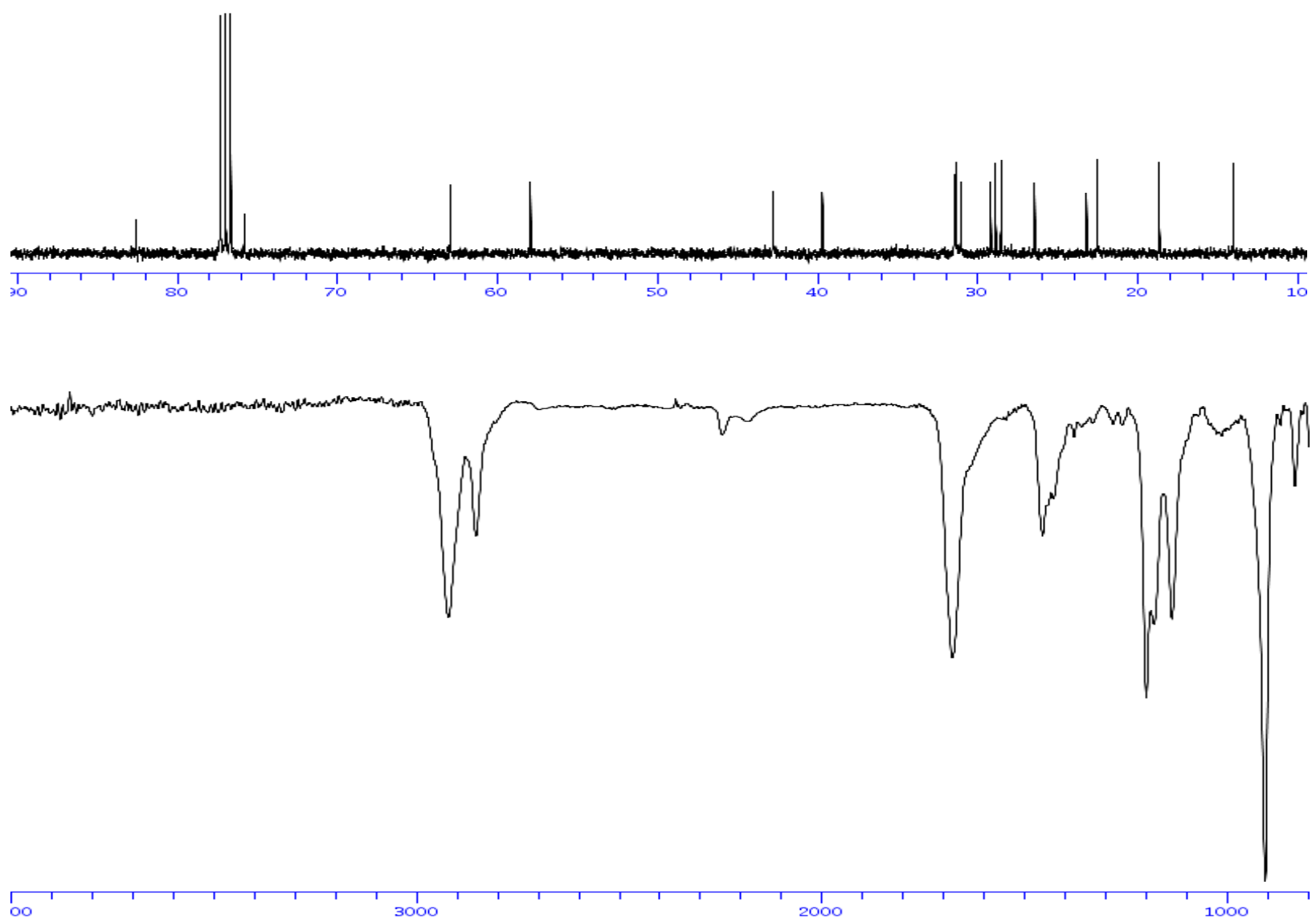
2-(Non-2-yn-1-yl)indoline (10ha')

Solvent: $C D C I 3$

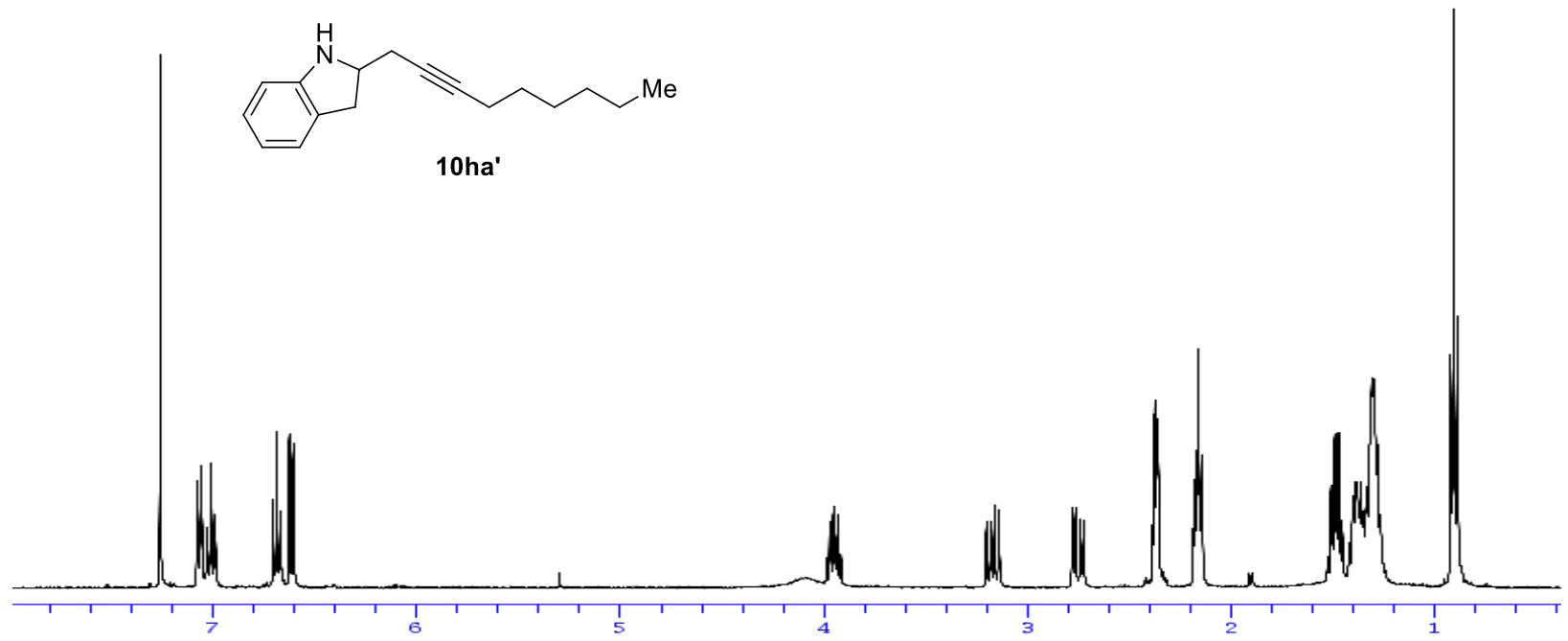

Solvent: $C D C I 3$

$100.61 \mathrm{MHz}$
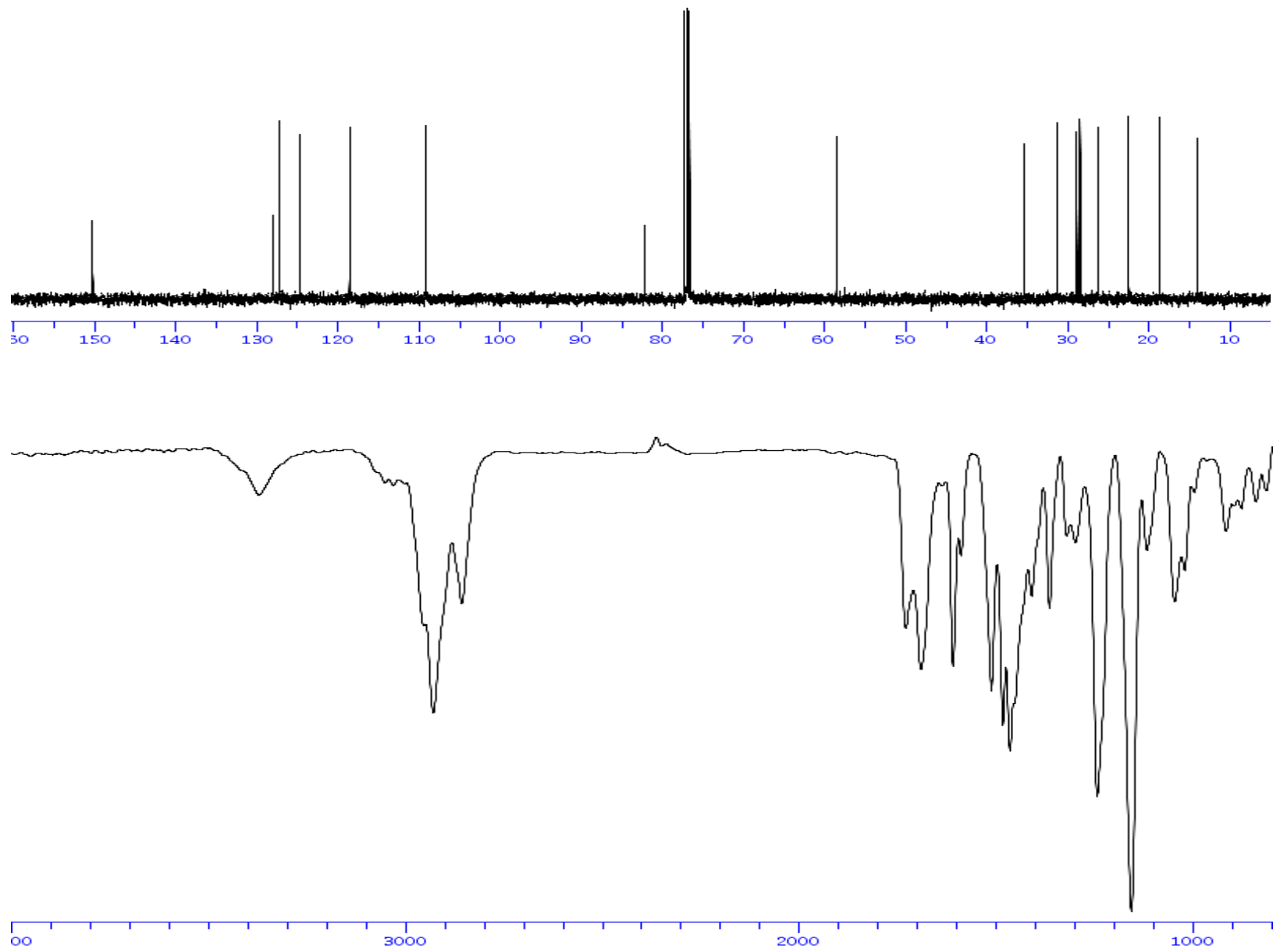
2-(Non-2-yn-1-yl)-1-phenylpyrrolidine (10ia)

solvent: $C D C I 3$

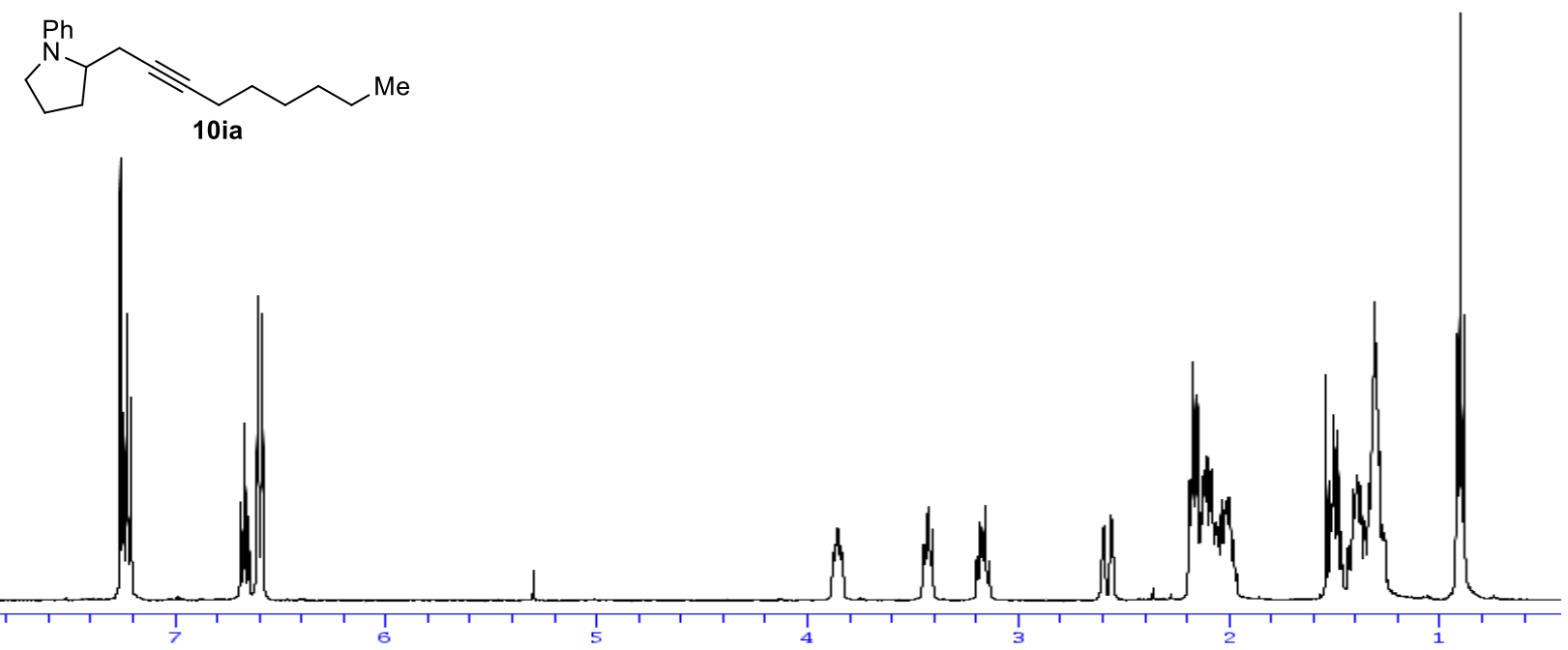

solvent: $C D C I 3$
Frequency. $100.61 \mathrm{MHz}$
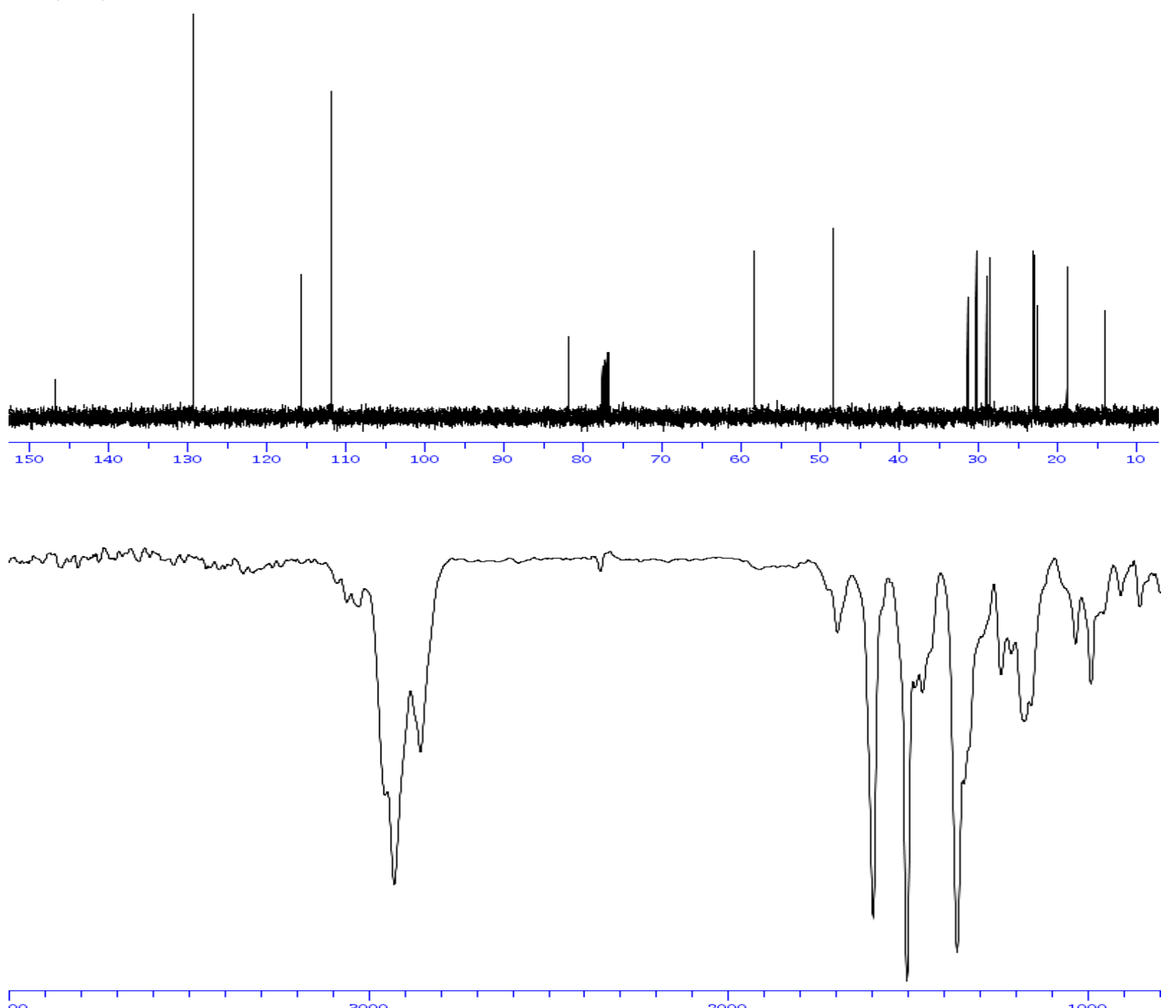
1-(4-Methoxyphenyl)-2-(non-2-yn-1-yl)pyrrolidine (10ja)

solvent: $\mathrm{CDC1}$
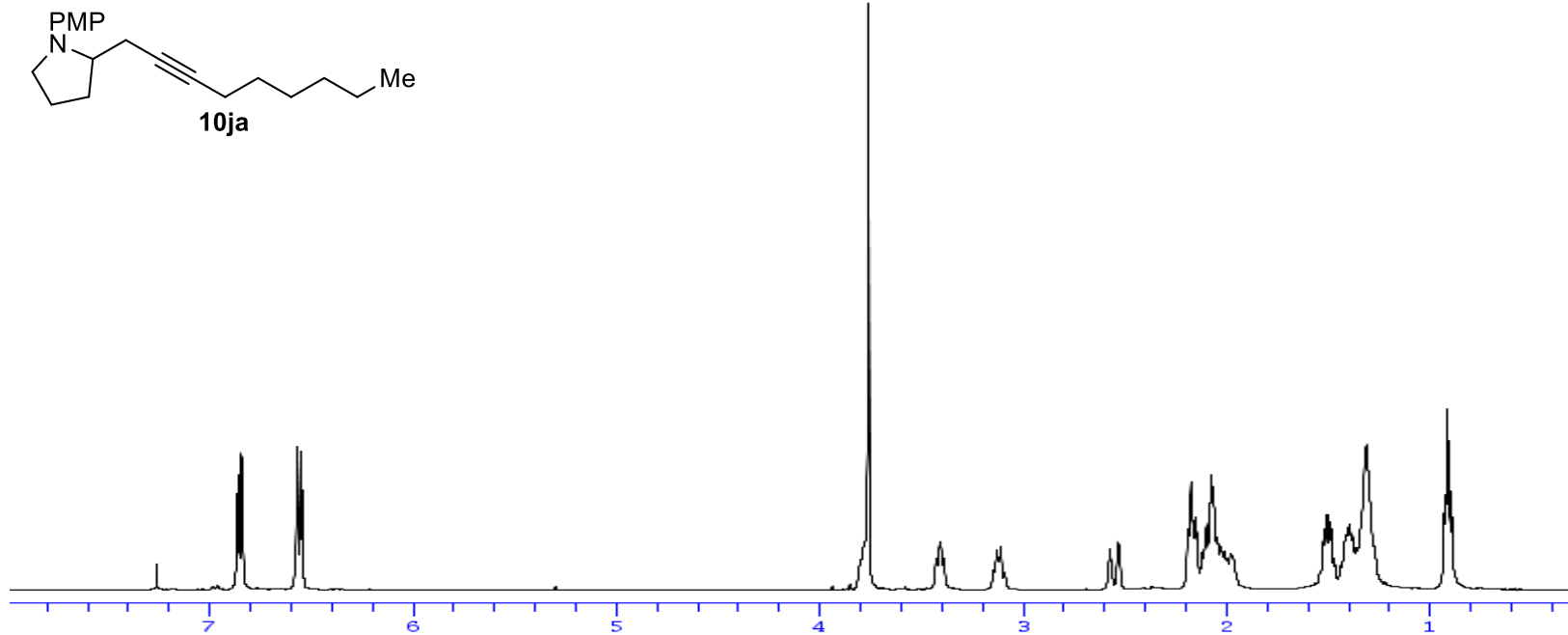

solvent: $\mathrm{CDCl} 3$

$00.61 \mathrm{MHz}$
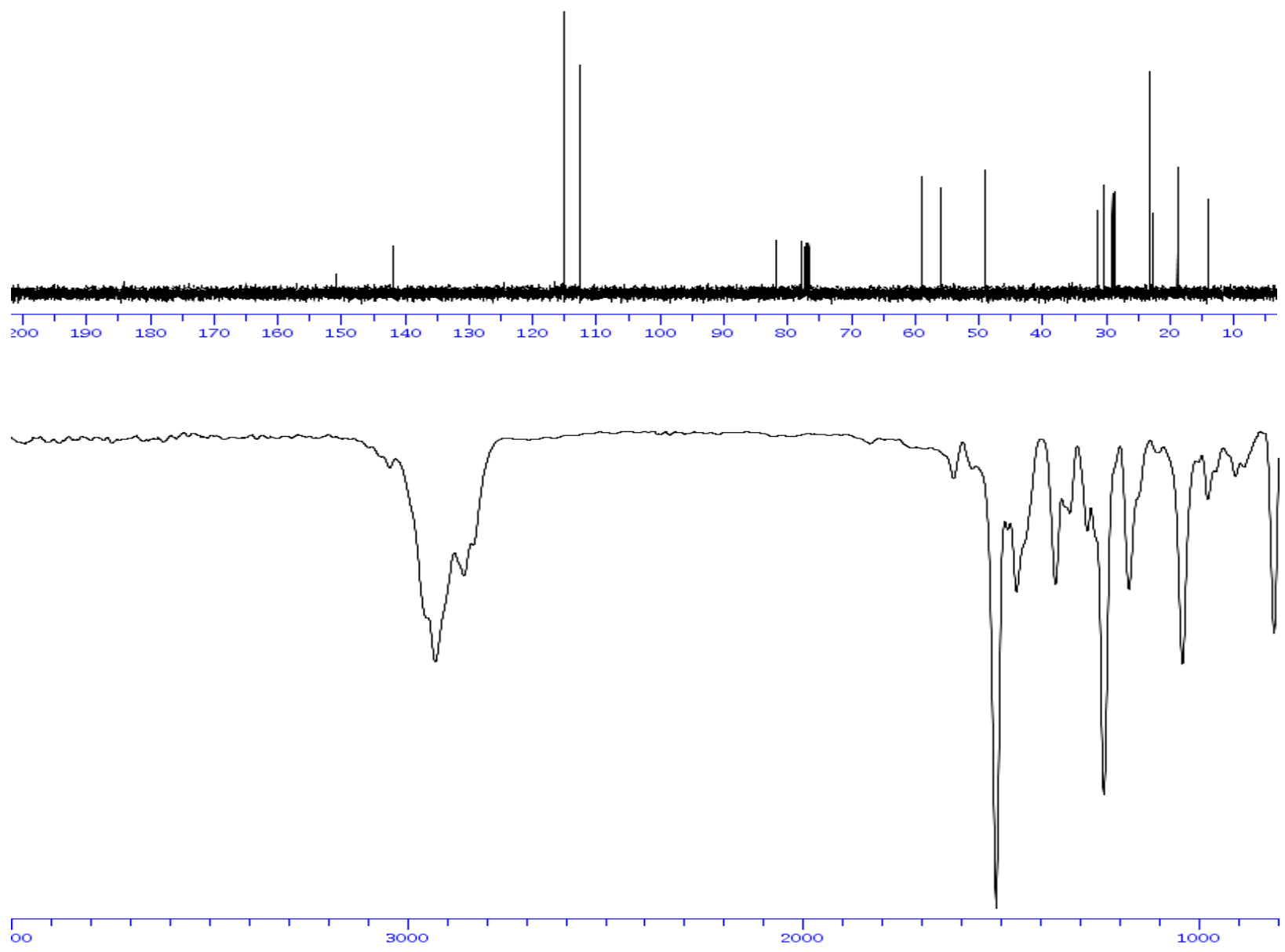
2-Nonyltetrahydrofuran (11aa)

Solvent: $\mathrm{CDCI} 3$

requency. $400.13 \mathrm{MHz}$

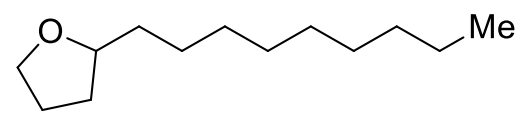

11 aa

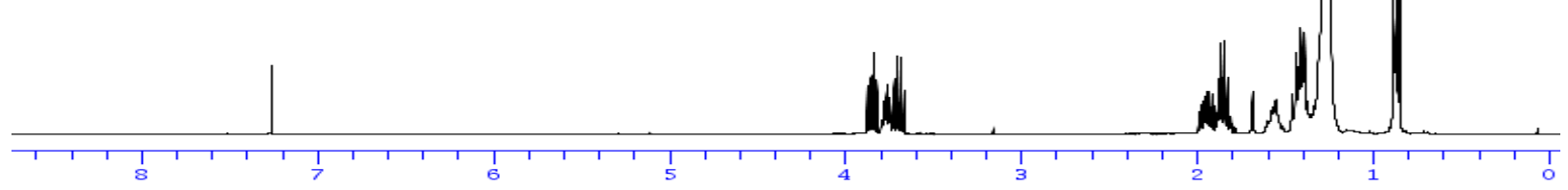

Solvent: $C D C I 3$

Frequency. $100.61 \mathrm{MHz}$
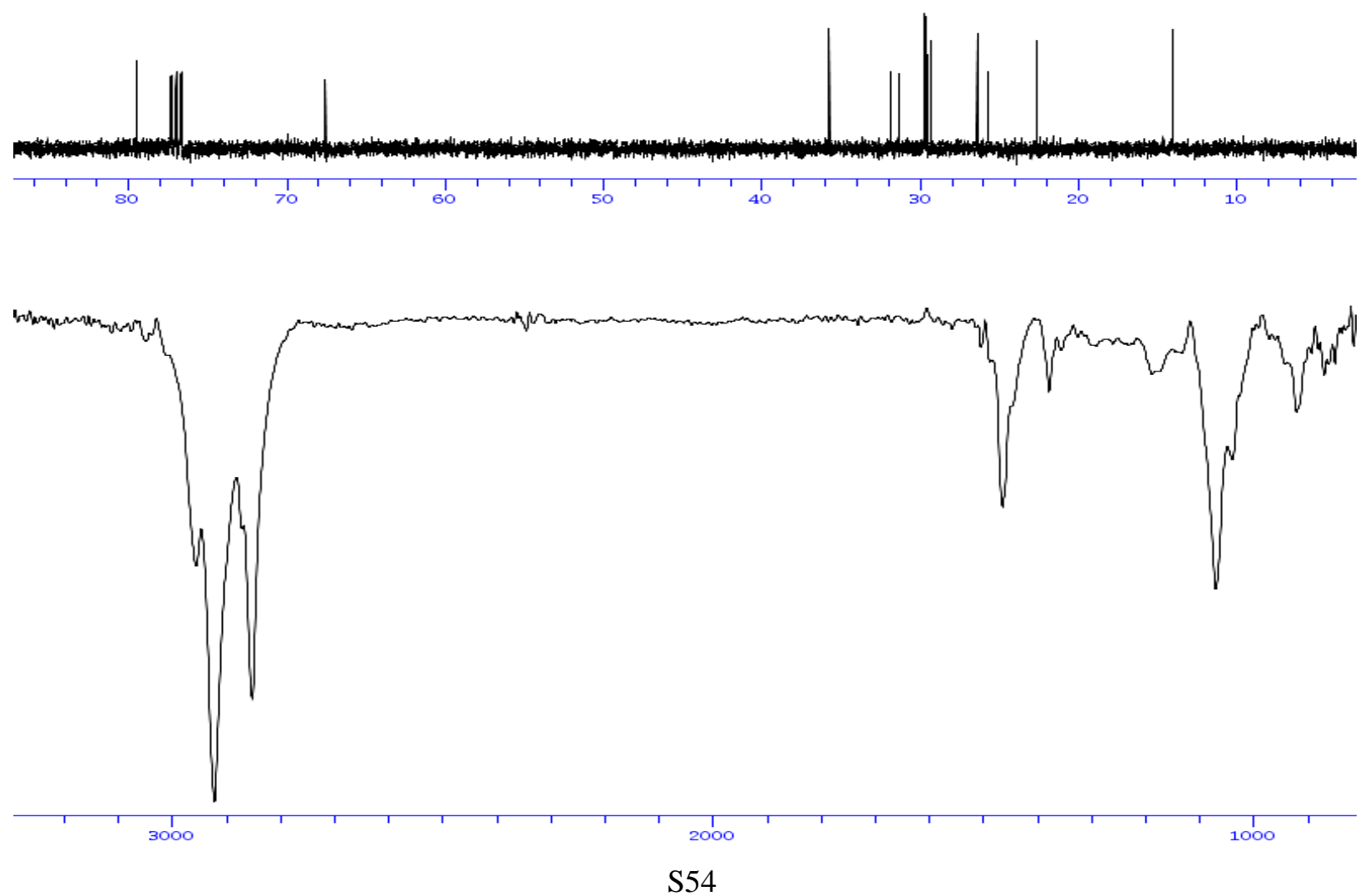


\section{2-Nonylpyrrolidine (12aa')}

Solvent: $\mathrm{CDCl} 3$<smiles>CCCCCCCCCC1CCCN1</smiles>

12aa'

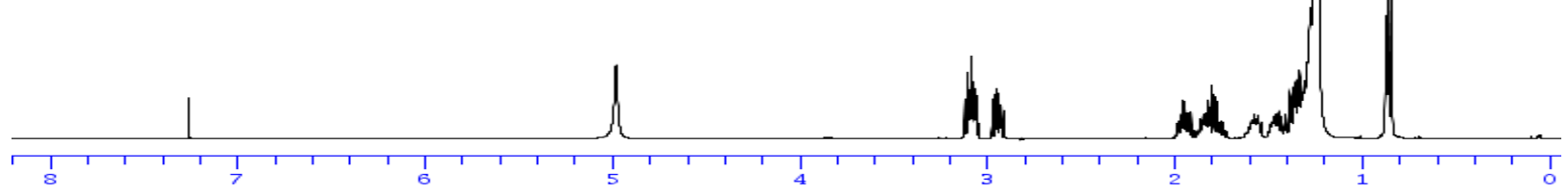

Solvent: $C D C I 3$

Frequency $100.61 \mathrm{MHz}$
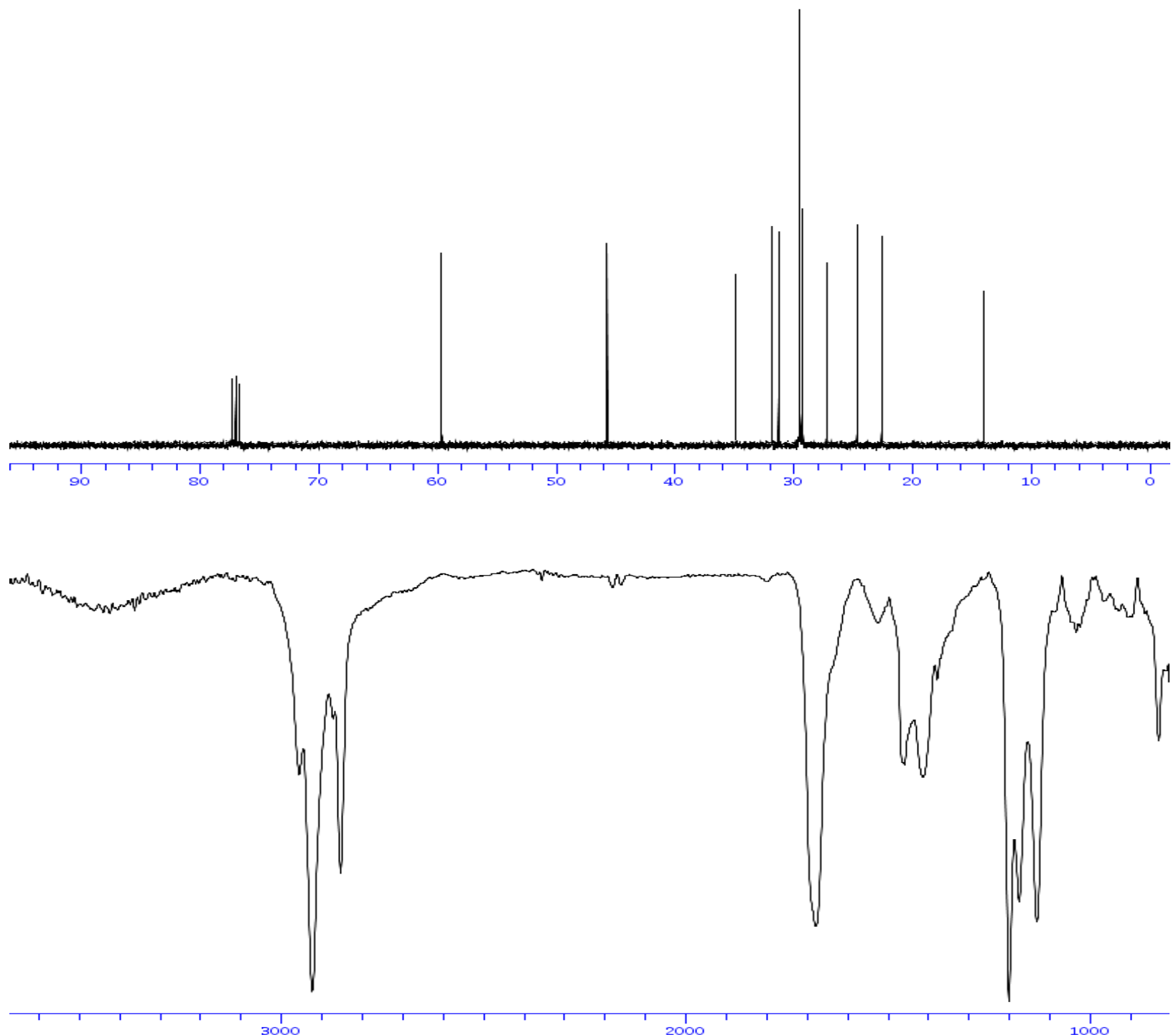
(((2,7-dimethylocta-3,5-diyne-2,7-diyl)bis(oxy))bis(methylene))dibenzene (16)

Frequency.400.13 $\mathrm{MHz}$

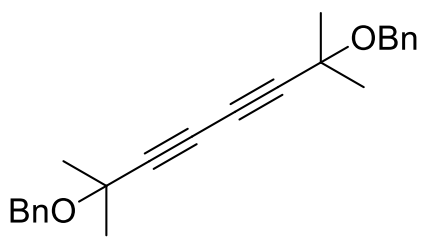

16

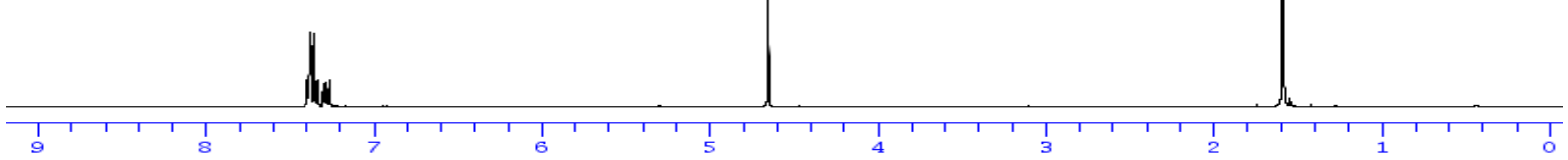

Solvent: $C D C I 3$

Frequency. $100.61 \mathrm{MHz}$
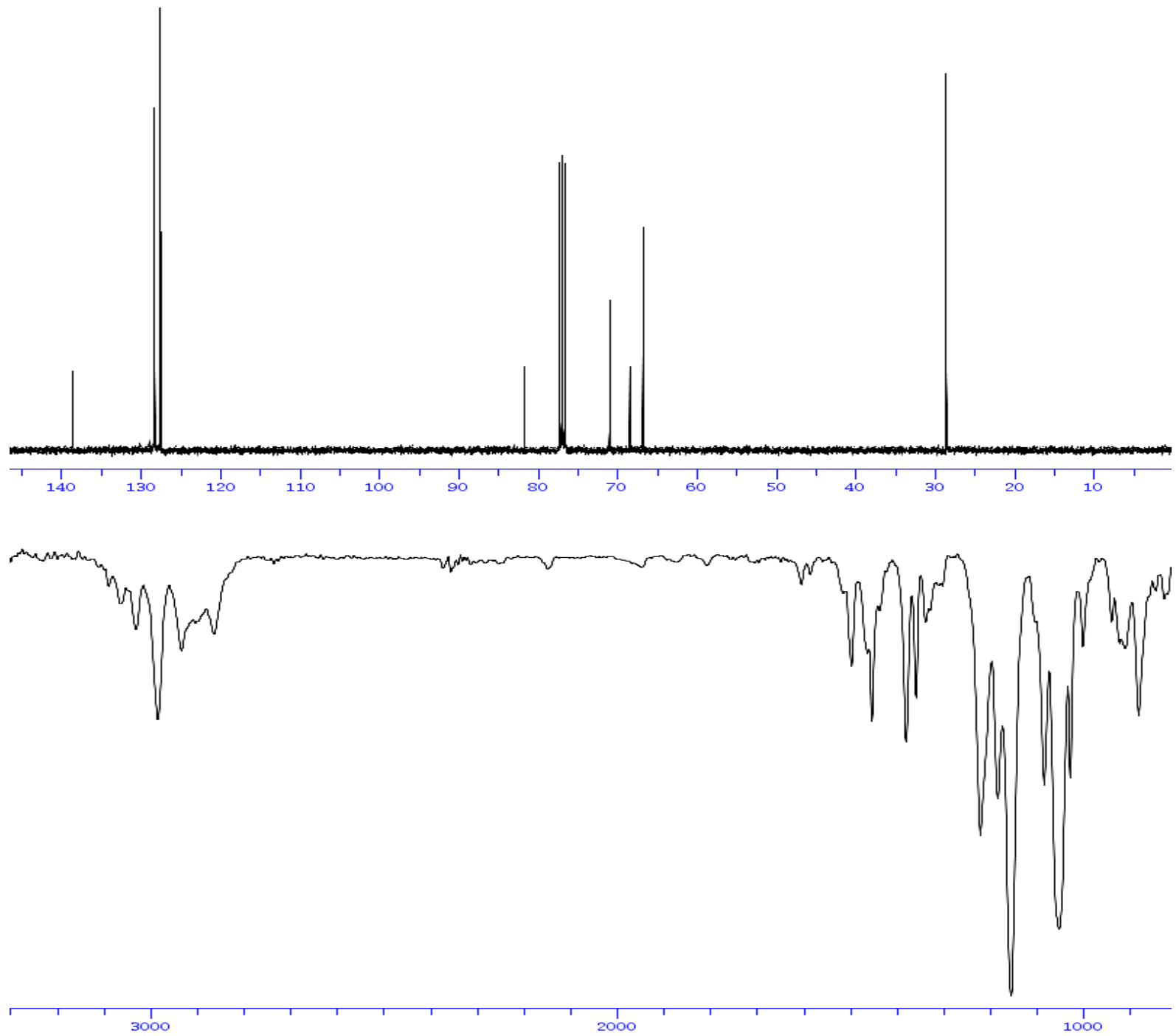